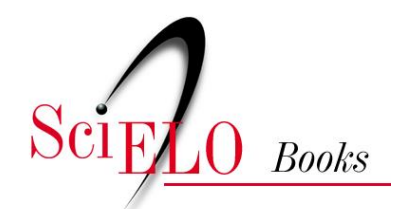

\title{
Antropologia, saúde e envelhecimento
}

\author{
Maria Cecília de Souza Minayo \\ Carlos E. A. Coimbra Jr. \\ (orgs.)
}

MINAYO, MCS., and COIMBRA JUNIOR, CEA., orgs. Antropologia, saúde e envelhecimento [online]. Rio de Janeiro: Editora FIOCRUZ, 2002. Antropologia \& Saúde collection, 209 p. ISBN: 978-85-7541-304-3. Available from SciELO Books $<$ http://books.scielo.org $>$.

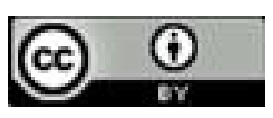

All the contents of this work, except where otherwise noted, is licensed under a Creative Commons Attribution $\underline{4.0 \text { International license. }}$

Todo o conteúdo deste trabalho, exceto quando houver ressalva, é publicado sob a licença Creative Commons Atribição 4.0.

Todo el contenido de esta obra, excepto donde se indique lo contrario, está bajo licencia de la licencia $\underline{\text { Creative }}$ Commons Reconocimento 4.0. 


\section{Antropologia, Saúde e Envelhecimento}




\section{FUNDAÇÃO OSWALDO CRUZ}

Presidente

Paulo Gadelha

Vice-Presidente de Ensino, Informação e Comunicação

Nisia Trindade Lima

\section{EDITORAFIOCRUZ}

Diretora

Nísia Trindade Lima

Editor Executivo

João Carlos Canossa Mendes

Editores Científicos

Gilberto Hochman e Ricardo Ventura Santos

Conselho Editorial

Ana Lúcia Teles Rabello

Armando de Oliveira Schubach

Carlos E. A. Coimbra Jr.

Gerson Oliveira Penna

Joseli Lannes Vieira

Ligia Vieira da Silva

Maria Cecília de Souza Minayo

Coleção Antropologia e Saúde

Editores Responsáveis: Carlos E. A. Coimbra Jr.

Maria Cecília de Souza Minayo 


\section{Antropologia, Saúde e Envelhecimento}

Maria Cecília de Souza Minayo

Carlos E. A. Coimbra Jr.

organizadores

$2^{\mathrm{a}}$ reimpressão 
Copyright $^{\odot} 2002$ dos autores

Todos os direitos desta edição reservados à

Fundação Oswaldo Cruz / Editora

ISBN: 85-7541-008-3

$1^{\mathrm{a}}$ edição: 2002 | $1^{\mathrm{a}}$ reimpressão: 2004 | 2 ${ }^{\mathrm{a}}$ reimpressão: 2011

Projeto Gráfico e Editoração Eletrônica:

Angélica Mello

Capa:

Danowski Design

Ilustração da Capa:

A partir do desenho de Hans Arp para a capa de L'Art Comtemporain, $n^{\circ}$ 3, 1930, Paris

Revisão:

Irene Ernest Dias

Copidesque:

Ana Tereza de Andrade

ESTA PUBLICAÇÃO CONTOU COM PARCIAL APOIO FINANCEIRO DO PROGRAMA DE PÓS-GRADUAÇÃO EM SAÚDE PÚBLICA DA ESCOLA NACIONAL DE SAÚDE PÚBLICA/FIOCRUZ, ATRAVÉS DO PROGRAMA DE APOIO À PÓS-GRADUAÇÃO (PROAP/CAPES).

Catalogação-na-fonte

Centro de Informação Científica e Tecnológica

Biblioteca Lincoln de Freitas Filho

M663a Minayo, Maria Cecília de Souza (org.)

Antropologia, saúde e envelhecimento. / Organizado por Maria Cecília de Souza Minayo e Carlos E. A. Coimbra Jr. Rio de Janeiro: Editora FIOCRUZ, 2002.

212p. (Coleção Antropologia \& Saúde)

1. Envelhecimento. 2. Direito dos idosos. 3. Saúde do idoso. 4. Envelhecimento da população. 5. Relações familiares.

CDD - 20.ed. -362.6

2011

EDITORA FIOCRUZ

Av. Brasil, 4036 - 1o andar - sala 112 - Manguinhos

21040-361 - Rio de Janeiro - RJ

Tels: (21) 3882-9039 e 3882-9007

Fax: (21) 3882-9006

e-mail: editora@fiocruz.br

www.fiocruz.br/editora 


\section{Autores}

\section{- Alda Britto da Motta}

Doutora pela Universidade Federal da Bahia e professora do Departamento de Sociologia da mesma Universidade.

\section{- Ana Zahira Bassit}

Doutora em Saúde Pública. Professora Titular do Curso de Psicologia da Universidade Braz Cubas de Moji das Cruzes (SP).

\section{- Carlos E. A. Coimbra Jr. (organizador)}

$\mathrm{PhD}$ em Antropologia pela Universidade de Indiana. Pesquisador Titular da Escola Nacional de Saúde Pública (Ensp/Fiocruz) e editor da revista Cadernos de Saúde Pública.

\section{- Célia Pereira Caldas}

Doutora em Enfermagem pela Escola de Enfermagem Anna Nery da Universidade Federal do Rio de Janeiro. Professora Adjunta do Departamento de Saúde Pública da Faculdade de Enfermagem da Universidade do Estado do Rio de Janeiro e Vice-Diretora da Universidade Aberta da Terceira Idade.

\section{- Cornelia Eckert}

Doutora em Antropologia pela Université de Paris e professora do Departamento de Antropologia da Universidade Federal do Rio Grande do Sul (Porto Alegre).

\section{- Edinilsa Ramos de Souza}

Doutora em Saúde Pública pela Escola Nacional de Saúde Pública (Ensp/Fiocruz). Pesquisadora Titular da Fundação Oswaldo Cruz e coordenadora executiva do Centro Latino-Americano de Estudos sobre Violência e Saúde (Claves/Fiocruz).

\section{- Elizabeth Uchôa}

$\mathrm{PhD}$ em Antropologia pela Universidade de Montréal. Professora Adjunta do Departamento de Psiquiatria e Neurologia da Faculdade de Medicina da Universidade Federal de Minas Gerais. Pesquisadora Titular do Laboratório de Epidemiologia e Antropologia Médica do Centro de Pesquisas René Rachou/Fiocruz e também do Núcleo de Estudos em Epidemiologia e Antropologia do Envelhecimento (Cenepi/FNS/MS).

\section{- Esther Jean Matteson Langdon}

PhD pela Tulane University, com pós-dotorado na Universidade de Indiana. Professora do Programa de Pós-Graduação em Antropologia Social da Universidade Federal de Santa Catarina (Florianópolis). 


\section{- Josélia O. A. Firmo}

Mestre em Epidemiologia pela Universidade Federal de Minas Gerais e doutoranda pelo Programa de Pós-Graduação em Saúde Pública pela Escola Nacional de Saúde Pública (Ensp/ Fiocruz). Pesquisadora do Laboratório de Epidemiologia e Antropologia Médica do Centro de Pesquisas René Rachou/Fiocruz e do Núcleo de Estudos em Epidemiologia e Antropologia do Envelhecimento (Cenepi/FNS/MS).

\section{- Liana Furtado Ximenes}

Especialização em Saúde Pública pela Escola Nacional de Saúde Pública(Ensp/Fiocruz). Mestranda em Saúde da Criança e da Mulher pelo Instituto Fernandes Figueiras/Fiocruz.

\section{- Maria Cecília de Souza Minayo (organizadora)}

Socióloga, Antropóloga e Sanitarista. Pesquisadora Titular da Fundação Oswaldo Cruz e coordenadora científica do Centro Latino-Americano de Estudos sobre Violência e Saúde (Claves/Fiocruz) e editora científica da revista da Associação Brasileira de Pós-Gradiação em Saúde Coletiva, Ciência \& Saúde Coletiva. É também Representante Regional para a América Latina do Fórum Mundial de Ciências Sociais e Medicina.

\section{- Maria Fernanda F. de Lima-Costa}

Doutora em Medicina pela Universidade Federal de Minas Gerais (UFMG), com pós-doutorados em Epidemiologia, na Johns Hopkins University e na University of London. Pesquisadora Titular da Fundação Oswaldo Cruz, chefiando o Laboratório de Epidemiologia e Antropologia Médica do Centro de Pesquisas René Rachou/Fiocruz. É também professora de Epidemiologia do Departamento de Medicina Preventiva e Social da UFMG e coordenadora do Núcleo de Estudos em Epidemiologia e Antropologia do Envelhecimento (Cenepi/FNS/Ministério da Saúde).

\section{- Paulo César Alves}

Doutor em Sociologia pela Universidade de Liverpool. Professor Titular do Departamento de Sociologia da Universidade Federal da Bahia (Ufba) e coordenador do Núcleo de Estudos em Ciências Sociais e Saúde (Ecsas/Ufba). É também pesquisador do CNPq.

\section{- Rita Maria Heck}

Doutora em Enfermagem. Professora de Enfermagem em Saúde Pública/Saúde Coletiva da Faculdade de Enfermagem e Obstetrícia da Universidade Federal de Pelotas (RS) e coordenadora do Núcleo de Estudos e Pesquisas em Enfermagem.

\section{- Russel Parry Scott}

PhD em Antropologia pela University of Texas. Professor de Antropologia da Universidade Federal de Pernambuco (UFPE) e coordenador do Núcleo de Família, Gênero e Sexualidade. Integra também a Comissão Nacional de População e Desenvolvimento e participa no Núcleo de Saúde Pública da UFPE.

\section{- Suely Ferreira Deslandes}

Doutora em Ciências (Saúde Pública) pela Escola Nacional de Saúde Pública (Ensp/Fiocruz). Pesquisadora do Instituto Fernandes Figueiras/Fiocruz e assessora da Coordenação Nacional de DST/Aids. 


\section{SUMÁRI0}

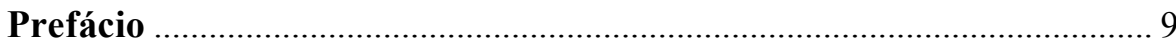

\section{Introdução}

Maria Cecília de Souza Minayo \& Carlos E. A. Coimbra Jr.

1. Envelhecimento e Saúde: experiência e construção cultural Elizabeth Uchôa, Josélia O. A. Firmo \& Maria Fernanda F. de Lima-Costa 25

2. Envelhecimento e Sentimento do Corpo Alda Britto da Motta 37

3. O Idoso em Processo de Demência: o impacto na família Célia Pereira Caldas 51

4. A Cultura do Medo e as Tensões do Viver a Cidade: narrativa e trajetória de velhos moradores de Porto Alegre Cornelia Eckert

5. Envelhecimento e Juventude no Japão e no Brasil: idosos, jovens e a problematização da saúde reprodutiva Russel Parry Scott 103

6. Envelhecimento, Relações de Gênero e o Papel das Mulheres na Organização da Vida em uma Comunidade Rural Rita Maria Heck \& Esther Jean Matteson Langdon 
7. Nervoso e Experiência de Fragilização: narrativa de mulheres idosas Paulo César Alves...

8. História de Mulheres: reflexões sobre a maturidade e a velhice Ana Zahira Bassit 175

9. O Idoso sob o Olhar do Outro

Edinilsa Ramos de Souza, Maria Cecília de Souza Minayo, Liana Furtado Ximenes \& Suely Ferreira Deslandes 


\section{Prefácio}

Em um estudo realizado pelo Centro de Documentação da Unati/Uerj relativo à produção científica brasileira apenas com os trabalhos de dissertações e teses sobre o tema terceira idade, foram observados alguns dados interessantes. A pesquisa já identificou 511 trabalhos, sendo $78 \%$ correspondentes a dissertações de mestrado e $22 \%$ a teses de doutorado. As primeiras obras catalogadas referem-se a $7 \%$ de trabalhos identificados na década de 70, cerca de $30 \%$ nos anos 80 e os restantes nos anos 90 e em 2000 e 2001.

Tais referências foram organizadas em duas grandes áreas: ciências sociais e humanas (sociologia, antropologia, psicologia, serviço social, educação e comunicação social) e área biomédica e saúde pública (políticas de saúde, serviços de saúde, epidemiologia, medicina, nutrição, enfermagem e educação física). Os temas destes trabalhos giram em torno de alguns eixos: o idoso de hoje diante do mundo urbano, industrializado, informatizado, evocando seu passado por meio da memória, vivenciando experiências de inúmeras transformações nos mais diversos campos da vida. $\mathrm{O}$ envelhecimento e a velhice, em especial, são tratados por meio de representações sociais dos próprios idosos, de seus familiares, de cuidadores e de profissionais de saúde. Os pontos de reflexão se concentram na identidade, no sentido existencial, na personalidade e na auto-estima. Como aspectos mais específicos, aparecem de forma recorrente a perspectiva feminina no envelhecimento, com destaque para a sexualidade, a menopausa, a solidão, o uso de medicamentos e alguns agravos à saúde.

A maioria quase absoluta da produção, independentemente do enfoque - desde aqueles de abordagem mais estereotipada e marcada pelos rótulos dominantes, em que o envelhecimento é um problema de Estado ou de saúde, e, portanto, deve ser regulado e tratado, até aqueles que reservam um espaço de reflexão e ações alternativas para este segmento etário da população, reconhecendo as perdas sem, no entanto, nunca tratar estes fatos tristes como sinônimo da velhice -, não incorpora uma dimensão que julgo contemporânea e de necessária reflexão. Existe pouca visão futurista, na qual profundas transformações sociais se fazem presentes, conseqüência não apenas da ampliação numérica dos idosos na sociedade, mas particularmente das mudanças biológicas com a ampliação dos conhecimentos da engenharia genética, o que mudará não apenas os indicadores demográficos, mas também a expectativa de vida, e, principalmente, a extensão do limite do tempo de vida, ou o relógio biológico.

Apesar da discussão da compressão da morbidade - termo cunhado por Fries (1981), que significa desenvolver estratégias que visem a levar a vida para o limiar mais próximo possível do limite máximo da espécie humana - ter sido introduzida na área de gerontologia a partir dos anos 80 , essa perspectiva ainda é bastante tímida. Nos dias 
atuais, o relógio biológico da espécie humana atinge entre 90 e 95 anos; estes valores são aceitos por vários estudiosos, mas nas próximas décadas é possível que o relógio biológico se amplie, alcançando de 120 a 130 anos.

O desafio que agora se coloca é o início da delimitação de cenários nos quais os avanços da genética e da biotecnologia permitirão ao ser humano alcançar os 120 a 130 anos de forma independente, livre de doenças, com a expectativa de vida atingindo o limite biológico máximo.

As transformações serão fantásticas, e elas estão muito próximas. Teremos indivíduos se aposentando aos 60 anos e iniciando um novo ciclo de trabalho por mais 30 ou 40 anos. Na área da educação, teremos possivelmente formação profissional e cursos universitários especificamente para cidadãos de mais de 60 anos. A ampliação da relação mulheres versus homens na sociedade será ainda maior, e suas consequiências ainda pouco projetadas. Os novos medicamentos poderão debelar muitas mortes hoje impossíveis de serem evitadas, mas a grande mudança, devido aos avanços dos fármacos, será realizada certamente no aspecto da sexualidade com a introdução dos novos medicamentos que permitirão uma vida sexual por mais 50 ou 60 anos em relação ao padrão atual. Possivelmente, teremos, em um futuro próximo, famílias com cinco ou seis gerações, muitas delas com várias gerações desempregadas, devido ao processo de globalização, e os mais idosos do clã sendo o grande sustentáculo, pelo fato de possuírem uma aposentadoria e terem conseguido uma nova reinserção no mercado de trabalho.

A produção cientifica brasileira, conforme o estudo realizado pela Unati se concentra basicamente na área das políticas de saúde, da medicina ou do campo comportamental. Estudos que visem a entender os rótulos que a sociedade quer impor a este grupo etário, como os desvendados por este livro, são de fundamental importância para podermos pensar no novo idoso das próximas décadas. Nosso desafio atual, e aí reside a importância dessa coletânea, é entender de forma correta o idoso de hoje para então podermos traçar os cenários das importantes transformações que se avizinham. A constatação que o estudo da Unati aponta é que a produção cientifica brasileira se amplia em termos numéricos, mas que ainda carece de uma reflexão mais qualificada e aguçada. Este livro poderá abrir alguns caminhos para os novos pesquisadores que invertam a estatística da atual produção científica brasileira, muito centrada em um conhecimento medicalizante, estigmatizante, normalizadora e pouco inovadora. Ao se questionar o que foi produzido na área, e eu sou um destes autores, não estou querendo desqualificar a produção brasileira vigente, apenas sinalizo a necessidade de se explorarem novos horizontes, com base em projeções já bem configuradas e que estão bem mais próximas de se tornarem realidade.

Renato Veras

Diretor da Universidade Aberta da Terceira Idade/Uerj 


\title{
Introdução
}

\section{Entre a Liberdade e a Dependência: reflexões sobre o fenômeno social do envelhecimento}

\author{
Maria Cecília de Souza Minayo \& Carlos E. A. Coimbra Jr.
}

Reinauguração

Nossa idade - velho ou moço - pouco importa. Importa é nos sentirmos vivos e alvoroçados mais uma vez, e revestidos de beleza, a exata beleza que vem dos gestos espontâneos e do profundo instinto de subsistir enquanto as coisas em redor se derretem e somem como nuvens errantes no universo estável. Prosseguimos. Reinauguramos. Abrimos olhos gulosos a um sol diferente que nos acorda para os descobrimentos.

Esta é a magia do tempo.

Esta é a colheita particular que se exprime no cálido abraço e no beijo comungante, no acreditar na vida e na doação de vivê-la em perpétua procura e perpétua criação. E já não somos apenas finitos e sós. Carlos Drummond de Andrade

Somos sempre o jovem ou o velho em relação a alguém.

Pierre Bourdieu

Existe uma praxe na antropologia segundo a qual o pesquisador deve explicitar as razões, as condições e o processo de suas investigações. Esse relato das condições de seu trabalho permite ao leitor relativizar seus achados e localizar sua perspectiva por conseguinte, também se posicionar. Por isso, consideramos de bom tom apresentar os motivos que nos levaram a organizar um livro sobre o 'envelhecimento' que cruzasse os olhares da antropologia e das ciências da saúde.

Pelas regras de classificação dos ciclos da vida que vigoram em nossa sociedade, o Brasil precocemente entrou na rota do envelhecimento populacional. Nessa estrada que acolhe os caminhantes grisalhos e sulcados pela vida, o trânsito vai aos poucos ficando congestionado, a ponto de já serem mais de $31 \mathrm{mil}$ os brasileiros remanescentes do século XIX. É cada vez maior a população que, parafraseando o poeta, vai 
reinaugurando, ano a ano, seu frágil projeto de felicidade após os 60, “entre o gasto dezembro e o florido janeiro, entre a desmistificação e a expectativa, tornando a acreditar, a ser bons meninos e, como bons meninos, reclamando a graça dos presentes coloridos" (Andrade, 1966:56).

O Brasil dobrou o nível de esperança de vida ao nascer em relativamente poucas décadas, numa velocidade muito maior que os países europeus, os quais levaram cerca de 140 anos para envelhecer. Para se ter idéia do que isso significa, a esperança de vida ao nascer dos brasileiros era de 33,7 anos em 1900; 43, em 1950; 65, em 1990; chega quase a 70 anos na entrada do novo século; e prevê-se que ultrapasse os 75 anos em 2025. De 1950 a 2025 terá crescido 15 vezes, quando o restante da população terá conseguido um incremento de 5 vezes. Apesar de todo esse incremento, a maioria das pessoas nessa faixa etária está entre os 60 e os 69 anos, constituindo ainda menos de $10 \%$ da população total (Veras, 1995), quando na Europa, por exemplo, são as faixas acima de 70 anos as que mais crescem. No entanto, um país já é considerado 'velho' quando $7 \%$ de sua população são constituídos por idosos.

A previsão dos demógrafos é de que no ano 2020 existam cerca de 1,2 bilhão de idosos no mundo, dentre os quais 34 milhões de brasileiros acima de 60 anos, que, nesse caso, corresponderão à sexta população mais velha do planeta, ficando atrás apenas de alguns países europeus, do Japão e da América do Norte. Por tudo isso, é muito importante ouvir a "lógica interna desse grupo socioetário" e contar com ele para a realização de seus anseios e para a construção de um padrão de vida que lhes seja adequado.

O que nos chamou a atenção, ao programarmos o trabalho aqui apresentado, é que, até o momento, quase sempre outros atores têm falado pelos idosos. Se a focalizálos existem vários tipos de lentes, as fotografias das câmeras curiosas costumam não ir além de luzes, sombras e cores que as aparências revelam. E como os que observam são parte da perspectiva que adotam, o que fica das imagens são a contundência dos sinais de desgaste dos corpos, os vincos nas faces, a voz mais cadenciada, o andar mais vagaroso ou trôpego, a queda inexorável dos músculos e a fragilidade dos movimentos. Esse retrato, que é feio em relação aos padrões de beleza que adotam o jovem como símbolo, costuma receber um veredicto de quem o produz e de quem o contempla. É o veredicto que assinala a velhice como problema e como doença.

Nosso interesse foi tentar ir além; fazer novas perguntas, olho no olho dos que estão em plena estrada, 'na chuva para se molhar', e que por isso resistem ao rótulo que a sociedade quer lhes impor. Mais que isso, entender também os véus que cobrem a destinação antecipada ao lugar social estereotipado que o aparente cuidado social lhes reservou: o 'recolhimento interior' (eufemismo para o afastamento do trabalho); a 'inatividade' (rotulação dos aposentados e aposentadas); a 'prevenção das possíveis doenças' (medicalização da idade) ou as 'festinhas da terceira idade' (infantilização dessa etapa da vida).

Foi dessa vontade de encontrar um espaço alternativo de reflexão, em que várias possibilidades pudessem emergir - produzindo uma compreensão mais real das vivências, dos desejos e da avaliação de sua situação que essa vasta camada da população brasileira faz de si própria -, que surgiu a idéia de organizar este livro. Não optamos pela realização de uma pesquisa original de cunho etnográfico, mas sim por reunir em uma 
oficina de trabalho um pequeno grupo de pesquisadores estudiosos do assunto. Essa oficina foi realizada no Rio de Janeiro, em agosto de 2000, e contou com a participação de todos os que integram esta coletânea.

No colóquio, estabelecemos os rumos da presente publicação, que, em seu conjunto, amadureceu com base em críticas, comentários e sugestões formuladas pelos participantes. A partir daí, muitas perguntas puderam ser feitas, num processo de aprofundamento sucessivo que começou de forma intuitiva: será que estamos errados na resistência aos rótulos dominantes? Será que, por influência da época, estaremos sendo vítimas da ideologia-mito da eterna juventude, esse vírus que corrói a humanização do envelhecimento e da morte? Ou será, ao contrário, que os próprios limites do ciclo e do curso da vida estão se desfazendo, por causa do fenômeno irrefutável do aumento da esperança de vida a partir da segunda metade do século XX, aqui e em todo o mundo?

A medida da curiosidade deu lugar à idéia de transformar tais perguntas em questões teóricas sobre as descobertas que o 'envelhecimento à brasileira' estão suscitando. Com certeza, as constatações poderão servir de baliza para essa grande faixa da população que hoje marcha não numa estrada sem fim e sem sentido, mas para a larga porteira aberta de uma fazenda de colheitas. Nesse espaço de movimento e construção, continuam a existir não apenas os frutos, mas a semente, o plantar, a alegria dos brotos e todos os prazeres, dores e sofrimentos do ceifar, como em qualquer etapa da vida.

Mas com enormes diferenças: é simultaneamente o tempo do orgasmo da vida e da liberdade e o tempo da medida do possível e da dependência. Tudo concomitante e tudo diferenciado pela trajetória individual. É isso que Ana Bassit, Alda Motta e Rita Heck \& Esther Jean Langdon mostram em seus respectivos capítulos. Também é isso que já haviam evidenciado Lins de Barros (2000), Debert (2000), Peixoto (2000) e Motta (2000), dentre outros, em estudos sobre essa questão social no Brasil.

Esses autores vêm nos ensinar que, como muitas outras questões na sociedade ocidental, o assunto da velhice foi 'estatizado' e 'medicalizado', transformando-se ora em problema político, ora em 'problema de saúde', seja para ser regulado por normas, seja para ser pensado de forma preventiva, seja para ser assumido nos seus aspectos de disfunções e distúrbios que, se todos padecem, são muito mais acentuados com a idade.

No que concerne à saúde, em torno da geriatria se estabeleceu um grande mercado consumidor, refinando os instrumentos e as medidas que rotulam o cotidiano da existência dos idosos. A seu lado desenvolveram-se normas preventivas fundadas no uso nem sempre crítico da 'teoria do risco', tão problemática quando tenta, por meio de médias, justificar propostas preventivistas. Dessa forma, desconhece-se a complexidade dos sujeitos, criando-se uma estética da vida referenciada em proibições e regras gerais. A pergunta necessária é a seguinte: será que não existe possibilidade de introduzir, na receita do que é saudável, o ingrediente 'prazer de viver' como mote central dessa última e decisiva etapa da existência? Dizemos isso porque talvez seja esta a maior e mais contundente descoberta que este livro poderá trazer como contribuição da antropologia.

É complexo o tema do envelhecimento, pois complexos são todos os processos vitais experimentados desde o nascimento, a infância e a adolescência até a vida adulta. Recusamo-nos não a reconhecer a complexidade, mas sim a colocar como farinha do mesmo saco envelhecimento, doença, privação, dependência, tristeza e frustração. 
Aqui se trabalha para executar um movimento que positive o envelhecimento como um tempo produtivo específico da vida, emocional, intelectual e social, superando assim os estigmas da discriminação. Pois é essa discriminação internalizada que freqüentemente leva os idosos a uma atitude de negação, buscando parecerem mais jovens para serem aceitos e acolhidos, obscurecendo suas características, seus atributos e sua identidade (Lins de Barros, 2000). A positivação da identidade do idoso significa, por um lado, reconhecer o que há de importante e específico nessa etapa da vida para desfrutá-lo; por outro, compreender, do ponto de vista desse grupo social, os sofrimentos, as doenças e as limitações com toda a carga pessoal e familiar que tais situações acarretam, embora nunca tratando tais acontecimentos dolorosos e tristes como sinônimos de velhice.

O envelhecimento não é um processo homogêneo. Cada pessoa vivencia essa fase da vida de uma forma, considerando sua história particular e todos os aspectos estruturais (classe, gênero e etnia) a eles relacionados, como saúde, educação e condições econômicas. Os capítulos que integram este livro demonstrarão que os fatores que contribuem mais e melhor para diferenciar a vivência do envelhecimento são as redes de apoio social e comunicação, com ênfase na solidariedade familiar.

O que torna a velhice sinônimo de sofrimento é mais o abandono que a doença; a solidão que a dependência. Assim, nesta introdução, quatro aspectos centrais serão enfatizados, pois traduzem a síntese do pensamento dos autores: o envelhecimento como híbrido biológico-social; o envelhecimento como problema; o envelhecimento como questão pública; o velho como ator social.

\section{O Envelhecimento como Híbrido Biológico-social}

“O que é envelhecimento?”, pergunta Veras (1995:25) em seu livro País Jovem com Cabelos Brancos, para em seguida responder: "Velhice é um termo impreciso. (...) nada flutua mais do que os limites da velhice em termos de complexidade fisiológica, psicológica e social". O mesmo autor diz, numa tentativa de conceituação, que "do ponto de vista cultural, a velhice deve ser percebida diferentemente em um país com uma expectativa de 37 anos de vida, como Serra Leoa, e outro de 78 anos de vida, como é o caso do Japão" (1995:26).

Assim como Veras, os estudiosos que têm seus textos aqui publicados apresentam, como uma das primeiras questões a serem consideradas, a necessidade de desnaturalizar o fenômeno da velhice e considerá-la como uma categoria social e culturalmente construída.

Se, por um lado, o ciclo biológico próprio do ser humano assemelha-se ao dos demais seres vivos - todos nascem, crescem e morrem -, por outro, as várias etapas da vida são social e culturalmente construídas. Isto é, as diversas sociedades constroem diferentes práticas e representações sobre a velhice, a posição social dos velhos na comunidade e nas famílias e o tratamento que lhes deve ser dispensado pelos mais jovens. É isso que Parry Scott analisa em seu capítulo, numa instigante abordagem 
comparativa sobre o processo de envelhecimento no Japão e no Brasil. O autor reafirma a idéia de que, para se entender o lugar social dos idosos, é preciso compreender a forma como a sociedade organiza a estrutura, as funções e os papéis de cada grupo etário específico.

Os estudos antropológicos demonstram que a infância, a adolescência, a vida adulta e a velhice não constituem propriedades substanciais que os indivíduos adquirem com o avanço da idade cronológica. Pelo contrário: o processo biológico, que é real e pode ser reconhecido por sinais externos do corpo, é apropriado e elaborado simbolicamente por meio de rituais que definem, nas fronteiras etárias, um sentido político e organizador do sistema social. Como lembram Ariès (1981) e Elias (1990), essas fronteiras e suas apropriações simbólicas não são iguais em todas as sociedades nem na mesma sociedade, em momentos históricos diferenciados - nem num mesmo tempo, para todas as classes, todos os segmentos e gêneros.

No interior das diferenciações, no entanto, os estudos antropológicos revelam aspectos estruturais fundamentais, de tal forma que é possível transcender particularismos culturais e encontrar alguns traços comuns do fenômeno que poderiam ser considerados universais.

O antropólogo Leo Simmons (1945), por exemplo, analisou a situação dos velhos em 71 sociedades indígenas, tomando por base os seguintes parâmetros: formas de subsistência; direitos de propriedade; atividades econômicas; vida doméstica; organização política; conhecimento das tradições; valores e crenças e integração na família e no sistema de parentesco. Embora seu estudo possa fazer jus a críticas de que seja demasiadamente generalista, ele aponta questões interessantes para o que seriam "os desejos universais dos velhos nessas sociedades". Considerando o conjunto dos grupos estudados, segundo Simmons, todos os velhos desejam viver o máximo possível; terminar a vida de forma digna e sem sofrimento; encontrar ajuda e proteção para a progressiva diminuição das capacidades; continuar a participar das decisões que envolvem a comunidade; prolongar, ao máximo, conquistas e prerrogativas sociais como propriedade, autoridade e respeito.

A manipulação de categorias etárias, no entanto, é outro fenômeno comumente observado, geralmente exigindo um investimento político de definição de poderes para cada ciclo da vida, no estabelecimento de direitos, deveres e privilégios (Bourdieu, 1983). Sobre esse tema, Debert diz que "categorias e grupos de idade implicam a imposição de uma visão de mundo social que contribui para manter ou transformar as posições de cada um em espaços sociais específicos" (Debert, 2000:53).

No mesmo sentido, apesar de os desejos 'universais' dos idosos citados por Simmons (1945) estarem todos voltados para sua inclusão afetiva nos contextos sociais, Riffiotis (2000), também estudando o lugar do velho entre diferentes etnias africanas, assinala que em todas elas existe a idéia de que os jovens querem que os anciãos morram. Mais que isso, existem rituais por meio dos quais a sociedade adulta os separa radicalmente da convivência nas aldeias, quase sempre abandonando-os em cavernas ou outros lugares distantes do convívio de seu povo. Essas mesmas sociedades que os segregam, porém, igualmente colocam à prova os jovens adultos que os substituirão no governo da comunidade, para que fiquem evidentes as dificuldades que sentirão sem o 
apoio da experiência dos velhos. Os mitos demonstram que, em face dos dilemas de difícil solução, os novos dirigentes sucumbirão se não trouxerem, em seu socorro, algum daqueles anciãos abandonados em cavernas para morrer. Assim, o saber ancestral dessas sociedades evidencia a importância da conciliação e do reconhecimento intergeracional na obtenção do equilíbrio necessário à organização social.

\section{O Envelhecimento como Problema}

No imaginário social a velhice sempre foi pensada como uma carga econômica - seja para a família, seja para a sociedade - e como uma ameaça às mudanças. Essa noção tem levado as sociedades a subtraírem dos velhos seu papel de pensar seu próprio destino. No entanto, nunca faltaram exceções a tais práticas, o que pode ser exemplificado com o reconhecimento pelas sociedades indígenas da figura do pajé ou xamã ancião ou, nas sociedades ocidentais, dos poderosos, ricos e famosos quando gozam de saúde física, mental e econômica. As exceções, porém, não podem esconder as grandes dificuldades socioeconômicas que os idosos, particularmente os pobres, sofrem nos mais diferentes contextos de vida. Por isso mesmo, a velhice é por eles auto-assumida como 'problema', na mesma medida em que sofrem por causa dela e o imaginário social assim a define.

A forma mais comum de discriminação cultural tem sido o estigma de 'descartável', 'passado' ou 'peso social'. Como muito bem aponta Guimarães, "nos dicionários emocionais da população, velhice é sinônimo de decadência, de decrepitude e de perda de dignidade" (Guimarães, 1997:7).

O trabalho de Uchôa e colaboradores que integra este volume evidencia, empiricamente, a forma negativa de concepção do envelhecimento por parte dos moradores de uma cidade do interior mineiro, em contraposição às visões muito mais generosas que os idosos têm de si próprios. Os pesquisadores demonstram a distância entre a observação externa e o conceito formulado por eles, mesmo em situação de enfermidade e de dependência física. A visão depreciativa dos mais velhos tem sido, através dos tempos modernos, alimentada profundamente pela ideologia 'produtivista' que sustentou a sociedade capitalista industrial, para a qual, se uma pessoa não é capaz de trabalhar e de ter renda própria, de pouco ou nada serve para sua comunidade ou seu país.

No Brasil, o fenômeno do envelhecimento até pouco tempo atrás vinha sendo tratado como questão da vida privada, por representar ônus para a família, como assunto de caridade pública, no caso dos pobres e indigentes, e, de forma bastante reducionista, como questão médica. É claro que essa visão continua confirmada pelas práticas sociais de cuidado com os idosos. Mas o rápido crescimento dessa faixa da população passou a preocupar também muitas outras instituições sociais.

No caso da família, por exemplo, nos últimos cinqüenta anos, houve profundas transformações no seu desenho demográfico, nos seus ambientes, na sua composição e no seu tamanho, pari passu com a acelerada urbanização. Na medida em que diminuem os espaços residenciais e o número dos membros que entram no mercado de trabalho, 
comparativamente aumentam os que se retiram. Criam-se novas demandas de cuidados, necessidades de adaptação da arquitetura das casas, isolamento dos parentes em asilos, ou maior exigência de dedicação dos mais novos para proporcionar melhor qualidade de vida aos que se tornam dependentes. Sem falar no fato de que não são poucas as dificuldades de convivência entre as várias gerações que cada vez se distanciam mais culturalmente, numa sociedade em que os padrões de comportamento também têm mudado aceleradamente, como mostra o trabalho de Cornelia Eckert.

Também para a medicina e para a saúde pública, o envelhecimento tem se apresentado como problema. As mudanças na pirâmide populacional, que vai alargando seu ápice numa média de 2,5\% de crescimento anual, geram preocupações para o sistema de saúde, porque mesmo sem ter solucionado os problemas sanitários relativos à infância, à adolescência e aos trabalhadores, ambos terão de se equipar para dar respostas eficientes relativas à prevenção de enfermidades e à atenção aos enfermos idosos.

Por isso, em geral, os formuladores de políticas no Brasil referem-se ao 'custo social da população idosa', calculado como três vezes mais alto que o da população em geral (Veras, 1995). Demonstram também que esse custo mais elevado onera, sobretudo, o sistema de saúde, pois o crescimento da esperança de vida, historicamente, vem acompanhado, no mundo inteiro, de um aumento das doenças crônicas não infecciosas, como diabetes melito, distúrbios cardiovasculares, articulares, respiratórios e de movimento; doenças incapacitantes, como demência senil, doença de Alzheimer, doença de Parkinson; além do incremento das ocorrências de depressões e de falhas cognitivas.

Os capítulos escritos por Célia Caldas e Paulo César Alves exemplificam a dimensão dos sofrimentos de grupos específicos de idosos e de seus 'cuidadores', quase sempre familiares, que os acompanham até o final da vida. Esses sofrimentos costumam ser muito mais dramáticos para a população pobre, que acaba lotando os asilos públicos e conveniados, quase todos em situação de flagrante abandono ou padecendo, cronicamente, da falta de equipamentos e de pessoal especializado.

No Rio de Janeiro (capital com a maior proporção de idosos no país), Veras (1995) observou que $17 \%$ da sua amostra consideravam sua saúde ruim ou muito ruim, e os casos de distúrbio mental eram mais freqüentes nesse grupo. Embora $82,5 \%$ das pessoas entrevistadas se dissessem saudáveis ao responderem a questões auto-referidas, os problemas de saúde foram mencionados como prejudicais à qualidade de sua vida cotidiana. Cerca de 64,4\% delas apresentavam morbidades múltiplas. Ora, esses dados podem ser lidos sob duas faces: de um lado, para esse grupo etário, os transtornos da velhice não são considerados 'doenças'; de outro, servem para dimensionar o tamanho dos problemas a serem enfrentados pelo sistema de saúde na esfera da prevenção e do tratamento.

O estudo de Veras chama a atenção, igualmente, para o peso das condições socioeconômicas adversas, da pouca instrução e da escassez de atendimento no recrudescimento dos problemas físicos e mentais na velhice. O fato de $60 \%$ da população idosa hoje serem compostos por mulheres indica também a necessidade de um atendimento diferenciado por gênero. No conjunto, Veras (1995) assinala nesse grupo etário do Rio de 
Janeiro elevada prevalência de distúrbios cardiovasculares e articulares; deficiências visuais e auditivas e distúrbios mentais, como depressão e problemas cognitivos.

No caso brasileiro, a idéia de que os velhos constituem um problema social vem sendo construída sobremodo pelo Estado. Na sociedade ocidental contemporânea, o Estado é o grande regulador do curso da vida, do nascimento à morte, passando pelas fases de escolarização, de atividade no mercado de trabalho e de aposentadoria. Por causa disso, a idade cronológica é um princípio cultural de extrema relevância no moderno aparato jurídico-político, que concentra no indivíduo a atribuição de direitos e deveres; e no mercado de trabalho, a base da economia. Essa forma de organização difere, por exemplo, das comunidades indígenas e camponesas fundadas economicamente na unidade familiar.

A idéia do 'envelhecimento como problema' se expressa na constante divulgação dos déficits nos cálculos da previdência social, uma vez que o direito à aposentadoria (um direito dos idosos) se universalizou. O discurso sobre o "peso social que hoje os velhos constituem' tem nessa instância pública um lugar entronizado. É reforçado pela idéia de que a situação do aumento dessa população é insustentável com a manutenção do direito universal da aposentadoria. Portanto, o aparato do Estado tende a ver de forma catastrófica as próprias instituições político-sociais que criou para atender os idosos. Veras (1995:23) aponta assim a dimensão do problema:

Uma vez que mais da metade da população idosa do Brasil terá entre 60 e 69 anos, as decisões relativas à idade de aposentadoria, disponibilidade e direito à pensão, assim como outras questões relacionadas à força de trabalho, afetarão significativamente a economia brasileira no próximo século.

Talvez o dilema dos formuladores de política seja exatamente a impregnação, em seu horizonte mental, da idéia de envelhecimento como problema, sobretudo no sentido econômico de apropriação de bens e serviços por um número cada vez maior de pessoas mais velhas. Ora, essa idéia de falência da previdência social, da qual usufruem os idosos, como a grande vilã da política social no país deve ser relativizada. Pelo menos é o que mostra estudo recente do Instituto de Pesquisa Econômica Aplicada (Ipea) sobre a universalização de direitos sociais no Brasil. Os pesquisadores constataram que mais da metade das aposentadorias e pensões da Previdência Social, na zona rural das regiões Sul e Nordeste, é dirigida a mulheres viúvas, solteiras ou separadas. Vivendo sem companheiros, elas são responsáveis pelo sustento da casa e dos dependentes, contando apenas, para a sobrevivência sua e do grupo, com esse benefício.

No Nordeste, $58,6 \%$ das mulheres aposentadas e pensionistas são chefes de família. No Sul, 49,4\% delas o são. Embora a quantia recebida do INSS seja mínima, pelo fato de essas idosas rurais terem acumulado, ao longo de suas vidas, uma série de desvantagens como a dupla jornada e o trabalho sem remuneração, a extensão da aposentadoria rural a essas mulheres, depois da Constituição de 1988, mudou sua trajetória, ao reconhecer seu direito de cidadania e sua autonomia financeira.

O estudo do Ipea conclui que a aposentadoria rural hoje é um fator essencial de redução da pobreza no campo. Isso também mostra o trabalho de Rita Heck, que integra esta coletânea, no caso do interior do Rio Grande do Sul. Mas essa autora evidencia 
que, além do significado econômico de subsistência, a liberação financeira (ainda que muito modesta) vem acompanhada de um sentido cultural de independência da tutela familiar, sobretudo para as mulheres, trazendo-lhes uma qualidade e uma alegria de vida como nunca tiveram em outras etapas da existência. Os exemplos acima referem-se, de forma muito particular, ao envelhecimento em situações de pobreza e privação, mas, mesmo assim, aqui se expressa um significado positivo dessa etapa da vida, apontando para uma visão diferenciada em relação aos estereótipos sociais.

\section{O Envelhecimento como Questão Pública}

Na sociedade ocidental, não somente o ciclo da vida é socialmente padronizado como também seu curso passa, cada vez mais, a ser regulado pelo Estado, a despeito das potencialidades e dos problemas de cada um. A infância, a adolescência e a juventude são tempo de escolarização; a idade adulta é o tempo associado à procriação e à participação no mercado de trabalho; a velhice, o tempo da aposentadoria. Essa institucionalização crescente das fases da vida envolve todas as dimensões do mundo doméstico, do trabalho e, também, do consumo.

Para Wright Mills (1974), um dos mais importantes problemas para a sociologia é a compreensão do movimento de transformação de um fato particular em questão pública. No caso do envelhecimento, isso supõe enfatizar o sentido das mudanças que esse grupo social, crescente em número, em vigor e em organização, provoca na reorganização do poder, do trabalho, da economia e da cultura, atribuindo novo significado ao seu espaço tradicionalmente percebido como o da decadência física e da inatividade. Como questão pública, o fenômeno do envelhecimento deve ser focalizado positivamente para o desenvolvimento humano. Portanto, pensar a velhice como questão pública é bem diferente de tratá-la como problema social.

Seguindo o pensamento de Mills (1974), é importante descobrir quais seriam os formuladores de um novo sentido do envelhecimento e que interesses têm nessa destinação, uma vez que quem o formula publicamente ocupa, geralmente, posição privilegiada para fazê-lo e para representar os interesses dos outros. Há que descartar os agentes tradicionais ou é preciso compreender sua mudança de enfoque? No caso dos idosos, os porta-vozes mais legitimados têm sido os especialistas da geriatria, seja pela apropriação do avanço da ciência, seja pelo próprio reconhecimento social da sua prática médica. Mas também no interior desse grupo, as certezas são poucas, como ressalta Guimarães (1997:7):

todos sabem que a gerontologia e seus diversos ramos têm sido até então uma ciência tímida, adolescente; um barco carente de bons timoneiros e do sopro dos melhores ventos. Ainda assim, o conhecimento científico tem possibilitado avanços consideráveis que tornam factível um envelhecimento saudável a ponto de podermos antever o próximo século como o século dos velhos. Nossa responsabilidade tende a aumentar na mesma proporção da importância atual e futura de nossa atuação. 
Ora, se não é apenas a geriatria (que tende a focalizar as doenças consideradas próprias da idade) a grande líder da transformação do idoso em ator político, seu papel não pode deixar de ser reconhecido, juntamente com a combinação de vários outros atores da história social no pós-Segunda Guerra Mundial. A expressão mais cabal desse seu papel na redefiniçãa de espaços é a idéia contemporânea de terceira idade, uma nova construção social acrescentada às etapas da vida, referida entre a vida adulta e a velhice propriamente dita. Nomeando a população entre 60 e 75 anos na Europa, onde a esperança de vida vem alcançando 80 e 90 anos, essa 'invenção' se socializou no mundo. Veio a reboque de grandes avanços científicos na área de prevenção e tratamento de doenças crônicas, estabelecendo parâmetros cada vez mais definidos do desenvolvimento humano e conquistando descobertas que se concretizam em tecnologias de tratamento reconhecidamente eficazes e precisas.

É interessante notar que a maioria dos medicamentos mais modernos, por meio dos quais a indústria farmacêutica mais lucra, estão voltados para o 'envelhecimento com qualidade de vida' ou para manter o mito da imortalidade ou da eterna juventude, com base em pesquisas farmacológicas e genéticas de ponta.

Seria uma simplificação e um reducionismo dizer que o grande propulsor das transformações do papel atual do idoso na sociedade seja o mercado, mas não convém desconhecer seu lugar. É preciso lembrar que a 'terceira idade' é uma nova categoria social que designa o envelhecimento ativo e independente. Geralmente, essa etapa da vida se compõe de uma população disposta - quando tem condições econômicas mínimas para fazê-lo - à "ociosidade criativa" (De Masi, 2000) e à prática de múltiplas atividades físicas e culturais. Assim, torna-se impossível desconhecer o seu papel como 'consumidora', pois crescem pari passu a constatação desse fenômeno demográfico, o turismo, a moda, a cosmética, a medicina de reabilitação e a fisioterapia, a indústria de alimentação específica, novos padrões de construção, uma literatura específica, além de todas as práticas, instituições e agentes voltados para esse público cativo e em expansão.

A chamada 'terceira idade' se diferenciaria da quarta, de 75 a 85; ou da quinta, compreendendo os velhos acima desse patamar (Peixoto, 2000), como os países europeus já vêm classificando - sobretudo porque os sintomas e expressões de dependência física e mental vão se acentuando e são muito mais freqüentes nas últimas duas faixas, em que os serviços se concentram no desenvolvimento de medicamentos, residências, equipamentos e pessoal especializado para atendimento médico e social.

$\mathrm{Na}$ verdade, a situação da 'terceira idade' e do acelerado envelhecimento populacional, no Brasil e no mundo, inclui-se nos temas a gosto da globalização e da cultura que é produzida neste novo momento histórico, sobretudo pelas mudanças que provoca e pelas potencialidades que encerra. Como um fenômeno sobre o qual ainda há pouca reflexão, necessita, para sua compreensão, de uma perspectiva construtivista, em que as teorias e as propostas englobem os próprios atores delas destinatários. Mas, tomada como questão pública, ela é uma espécie de 'ícone' dos avanços que a sociedade alcançou, mesmo tendo em conta todas as diferenças entre países desenvolvidos e subdesenvolvidos, entre classes, gêneros e etnias. 
No caso nacional, a terceira idade revela os seguintes avanços positivos: o controle de muitas doenças infecto-contagiosas e potencialmente fatais; a diminuição das taxas de fecundidade; a queda da mortalidade infantil, graças à ampliação das redes de abastecimento de água e esgoto; o aumento da cobertura vacinal e da atenção básica à saúde; a acelerada urbanização; a universalização da previdência social e as profundas transformações nos processos produtivos e de organização do trabalho e da vida.

Todas essas mudanças, na realidade, induzem a que se coloque em pauta uma nova datação e um novo imaginário sobre as etapas da vida até então vigentes e utilizadas para marcar os rituais de passagem, assim como os direitos e deveres públicos e privados. O envelhecimento como questão pública retira esse tema do domínio individual e privado sem negá-lo, colocando-o num âmbito muito mais abrangente: na esfera da grande política e das políticas sociais. É preciso que, daqui para a frente, não nos esqueçamos de que, no Brasil, esse grupo etário reúne e reunirá uma população maior que qualquer sindicato de categoria e até mesmo que qualquer central sindical.

\section{0 ldoso como Ator Social}

Por mais incrível que possa parecer, há duas categorias sociais opostas e em construção olhando para o futuro do país. A primeira é a 'juventude', essa etapa entre a adolescência e o mundo adulto que, exatamente pela força de expansão da expectativa de vida e das exigências escolares, cada vez tende a ampliar seu tempo e a criar uma identificação específica. A segunda é a velhice, que não pode ser nominada nem tratada como há 50 anos, quando a expectativa de vida era apenas de 43 anos. Portanto, este último e mais novo ator individual e coletivo está redefinindo as relações familiares; construindo a medida de sua participação social; influenciando os rumos da política e, em conseqüência, criando, a partir de si, uma nova imagem e delineando uma preciosa etapa da vida, portadora de uma ética e de uma estética próprias.

Num estudo recente, Simões (2000) reconstruiu a história da constituição do movimento dos aposentados brasileiros. Com os termos 'luta', 'mobilização' e 'nova categoria' estruturando seu discurso ordenador desde o início dos anos 80 e culminando na segunda metade dos anos 90, os idosos se reuniram e foram para as ruas reivindicar reconhecimento de seus direitos previdenciários, aumento das aposentadorias e participação na gestão de seus interesses, com assento nos conselhos nacionais de Saúde e de Seguridade Social.

Na liderança da 'maior categoria do país', encontravam-se antigos líderes sindicais e de movimentos sociais. Nesse embate, os idosos brasileiros, nas duas últimas décadas, inauguraram um espaço próprio de ação, de cidadania e de inclusão. Modificaram o cenário da organização social e se estabeleceram como um grupo de interlocução política - os velhos elegem, destituem, dialogam, denunciam, recorrem à Justiça, incomodam e se fazem ouvir. Transformaram-se, como obra própria, em atores sociais e em atores políticos.

O estudo de Simões (2000) faz uma distinção interessante. Ao mesmo tempo que cresce e se estrutura o movimento dos aposentados, também se incrementam e se 
multiplicam os grupos e os movimentos da chamada 'terceira idade'. Os líderes dos aposentados não gostam muito dessas outras formas de expressão. Costumam dizer que as iniciativas da dita 'terceira idade' não são dirigidas a interesses da coletividade e atendem apenas a anseios individuais, oferecendo atividades culturais como as 'universidades abertas', os grupos de encontro, de lazer, de solidariedade, de atividades físicas e de excursões, entre outros.

Ora, olhando a efervescência dos dois movimentos, constata-se que não há contradição entre eles, mesmo porque os grupos de atividades culturais devem congregar pessoas que participam do movimento de aposentados e vice-versa. Mas há diferenças de ênfase: os movimentos socioculturais costumam reunir muito mais mulheres que homens, e os dos aposentados, mais homens que mulheres. Ambos, porém, revelam a busca do 'protagonismo' de 'uma nova categoria' - como revelam Ana Bassit, Rita Heck \& Jean Langdon, Alda Motta e Elizabeth Uchôa e colaboradores - que acotovela os jovens adultos, exigindo a abertura de espaço e novos arranjos nas estruturas de poder.

É preciso reconhecer que, do ponto de vista econômico, os idosos e, de forma destacada, 'a terceira idade' se configuram hoje como um mercado crescente e cada vez mais promissor no mundo dos bens de consumo, da cultura, do lazer, da estética, dos serviços de prevenção, atenção e reabilitação da saúde. Do ponto de vista sociológico, constituem um emergente ator social, com poder de influir nos seus destinos, pela sua significância numérica e qualitativa, por meio da construção de leis de proteção, de conquista de benefícios e pela presença no cenário político, no qual valem seu voto e sua representação. Como um novo construtor de cultura, o idoso tem papel insubstituível porque, radicalizando as novas situações, nada poderá ser como antes, sob pena de sua exclusão moral e social do projeto para o futuro do país.

Os chamados 'tempos pós-modernos' trouxeram à pauta algumas questões culturais que favorecem um novo pensamento sobre a 'terceira, quarta ou quinta idade'. A primeira é a relativização da centralidade da categoria 'trabalho' tal como foi pensada no mundo ocidental e na sociedade industrial - em que, como assinala Weber (1985), foi considerado ‘vocação’ e, como lembra Marx (1978), acabou sendo um fator de alienação e despersonalização. Hoje a sociedade está mais aberta para outras formas de identificação e madura para a crítica do 'homem unidimensional' que fez do trabalho para sobreviver seu único objetivo possível de vida. Cada vez mais se admitem outras formas de pertencimento social e tempo para o ócio criativo, possibilidade que vem junto com a perspectiva de diminuição da jornada de trabalho, como previu Marx (1984) em A Ideologia Alemã. A noção de 'consumidor cidadão' e a expansão das redes de comunicação, lazer e cultura estão contribuindo para dar força à produção e ao reconhecimento de outras possibilidades de identificação.

Em segundo lugar, e em conseqüência de uma abertura propiciada, sobretudo, pelas tecnologias de comunicação e informacionais, vem se ampliando o respeito ao pluralismo de comportamentos e de atividades, o que, em conseqüência, acaba por romper estereótipos ideológicos e comportamentais. Por fim, do ponto de vista cultural, observa-se uma valorização da subjetividade em todos os níveis do mundo da vida, da ciência e da política. 
Ao questionar a idéia do trabalho remunerado como a única forma de realização social e ao colocar em foco outras formas de estar no mundo e na sociedade, os tempos atuais permitem aos idosos, como nunca antes, construírem sua nova identidade sob uma ótica de trabalho não obrigatório, mas de utilidade e de sentido. Isso propicia outros espaços de expressão a serem inventados e desfrutados, contrapondo-se à pecha de 'descartáveis' ou à própria referência a si mesmos como 'inúteis'.

A maior abertura para o pluralismo de idéias, comportamentos e atitudes configura, para esses homens e essas mulheres, o espaço menos preconceituoso para seus desejos e possibilidades de realizações, retirando de suas testas a tarja repressora, na qual está escrito que ser velho é colocar o pijama de avô ou o chinelinho de avó, contar histórias do passado, parar de ousar e preparar-se para a morte.

Na verdade, não sem dor e conflitos, os papéis sociais estão mudando e podem mudar mais, à medida que os idosos se coloquem como atores das transformações com que sonham. Quase tudo está por fazer. As vivências, em maior profundidade, da própria subjetividade permitirão aos velhos afrontarem as repressões provocadas tanto pelas próprias necessidades do trabalho quanto pelos constrangimentos familiares, sendo mais autênticos e mais felizes.

Por fim, as novas possibilidades de comunicação, de viagens, de participação grupal, de ampliação da cultura, do cultivo de diferentes formas de lazer permitem também uma existência mais saudável. Mesmo nos bairros e nas condições em que vivem os mais pobres, é possível dar um novo sentido e articular atividades de encontro, comunicação e afeto. Para tudo isso, é importante mudar a idéia de que velhice é doença, substituindo-a por uma nova visão de um tempo no qual se pode optar com menos constrangimentos pelo rumo que se quer dar a esta última etapa da vida, produzindo dela uma síntese criadora. Essa autoria, para a qual não estão definidos os caminhos a priori, cabe ser inventada, tal qual tem sido feito pelos movimentos citados aqui. Dessa forma, a contribuição específica dos idosos será um bem para a sociedade e estabelecerá os contornos de seus próprios interesses, num mundo cheio de outros poderosos interesses.

\section{ReferênCIAS BiblIOGRÁFICAS}

ANDRADE, C. D. Poesias Completas. Rio de Janeiro: Aguilar, 1966.

ARIÈS, P. História Social da Criança e da Família. Rio de Janeiro: Guanabara, 1981.

BOURDIEU, P. Questões de Sociologia. São Paulo: Marco Zero, 1983.

DEBERT, G. G. A antropologia e os estudos dos grupos e das categorias de idade. In: LINS DE BARROS, M. M. (Org.) Velhice ou Terceira Idade? Estudos antropológicos sobre identidade, memória e política. 2.ed. Rio de Janeiro: FGV, 2000.

DE MASI, D. O Ócio Criativo. Rio de Janeiro: Sextante, 2000.

ELIAS, N. O Processo Civilizador: uma história dos costumes. Rio de Janeiro: Jorge Zahar, 1990. 
GUIMARÃES, R. M. Ciência, tempo e vida. Arquivos de Geriatria e Gerontologia, 1 (1):7-9, 1997.

INSTITUTO DE PESQUISA ECONÔMICA APLICADA - IPEA. Universalização de Direitos Sociais no Brasil: previdência rural nos anos 90. Brasília: IPEA, 2000.

LINS DE BARROS, M. M. (Org.) Velhice ou Terceira Idade? Estudos antropológicos sobre identidade, memória e política. 2.ed. Rio de Janeiro: FGV, 2000.

MARX, K. O Capital. Rio de Janeiro: Civilização Brasileira, 1978. Livro I.

MARX, K. A Ideologia Alemã. São Paulo: Hucitec, 1984.

MILLS, W. A Imaginação Sociológica. Rio de Janeiro: Zahar, 1974.

MOTTA, A. B. Chegando pra idade. In: LINS DE BARROS, M. M. (Org.) Velhice ou Terceira Idade? Estudos antropológicos sobre identidade, memória e política. 2.ed. Rio de Janeiro: FGV, 2000.

PEIXOTO, C. Entre os estigmas e a compaixão e os termos classificatórios: velho, velhote, idoso, terceira idade. In: LINS DE BARROS, M. M. (Org.) Velhice ou Terceira Idade? Estudos antropológicos sobre identidade, memória e política. 2.ed. Rio de Janeiro: FGV, 2000.

RIFFIOTIS, T. O ciclo vital contemplado: a dinâmica dos sistemas etários em sociedades negroafricanas. In: LINS DE BARROS, M. M. (Org.) Velhice ou Terceira Idade? Estudos antropológicos sobre identidade, memória e política. 2.ed. Rio de Janeiro: FGV, 2000.

SIMÕES, J. A. Velhice e espaço político. In: LINS DE BARROS, M. M. (Org.) Velhice ou Terceira Idade? Estudos antropológicos sobre identidade, memória e política. 2.ed. Rio de Janeiro: FGV, 2000.

SIMMONS, L. W. The Role of the Aged in Primitive Society. New Heaven: Yale University Press, 1945.

VERAS, R. P. País Jovem com Cabelos Brancos. Rio de Janeiro: Relume-Dumará, 1995.

WEBER, M. A Ética Protestante e o Espírito do Capitalismo. São Paulo: Pioneira, 1985. 


\title{
1 \\ Envelhecimento e Saúde: experiência e construção cultural
}

\author{
Elizabeth Uchôa, Josélia 0. A. Firmo \& Maria Fernanda F. de Lima-Costa
}

O envelhecimento populacional não é mais uma preocupação apenas dos países desenvolvidos, onde este fenômeno foi observado inicialmente. Hoje, é nos países em desenvolvimento que se verificam os maiores índices de mudanças (UNO, 1985; Waters et al., 1989). No Brasil, o crescimento da população idosa é cada vez mais relevante, em termos tanto absolutos quanto proporcionais (Berquó, 1999). Entre 1950 e 1991, a proporção de indivíduos com 60 ou mais anos de idade aumentou de 3,5\% para 7,3\%, e a proporção daqueles com 65 anos ou mais aumentou de 1,7\% para 4,5\% (FIBGE, 1950/ 1991). Em 1991, o número total de indivíduos idosos (65+) no país já ultrapassava os 7 milhões, e a estimativa para o ano 2025 é que o número de idosos ultrapasse os 30 milhões (Berquó, 1999; Veras, 1997).

A situação no Brasil faz eco no panorama mundial, caracterizando-se, entretanto, por algumas particularidades. Contrariamente aos países desenvolvidos, onde o aumento da esperança de vida resultou de melhoria considerável das condições de vida das populações, no Brasil muitos indivíduos estão hoje vivendo por mais tempo sem, necessariamente, dispor de melhores condições socioeconômicas ou sanitárias (Kalache, 1990, 1991). Além disso, em um país tão marcado por desigualdades, como o Brasil, o processo do envelhecimento pode reforçar desigualdades em termos da qualidade de vida e do bem-estar entre diferentes estratos da população, contribuindo para aumentar a chance de exclusão dos idosos (Berquó, 1999).

Assim, no contexto brasileiro, o acelerado crescimento da população idosa faz surgir um grande desafio: como garantir uma sobrevivência digna a todos aqueles que tiveram suas vidas prolongadas em anos? A busca de soluções adequadas exige a inclusão do envelhecimento da população brasileira como um elemento fundamental na elaboração das novas políticas e na agenda de investigações científicas do novo milênio.

No âmbito da saúde, o envelhecimento populacional é um fenômeno que gera novas demandas para os serviços e aumentos substanciais nos custos de programas (Neugarten, 1967; Birren, 1983; Fournier, 1989; Ducharme, 1992; Veras, 1992), exigindo o conhecimento de problemas prioritários e o desenvolvimento de ações visando à sua resolução.

Entretanto, mesmo reconhecendo que o envelhecimento das populações é uma das questões mais relevantes na agenda de estudos contemporâneos (Veras, Coutinho 
\& Coeli, 1997), os estudos epidemiológicos com base populacional são ainda raros no Brasil e até recentemente (Lima-Costa et al., 2000) restritos a grandes metrópoles, como São Paulo (Ramos, 1986; Ramos \& Goihman, 1989; Blay, Mari \& Ramos, 1989; Ramos et al., 1993; Najas et al., 1994) e Rio de Janeiro (Veras et al., 1989; Veras, Coutinho \& Nery Jr., 1990; Veras \& Coutinho, 1991; Veras \& Murphy, 1991; Veras, 1992).

Estudos epidemiológicos são imprescindíveis para a identificação dos problemas prioritários, dos grupos de pessoas mais vulneráveis a esses problemas e dos fatores de proteção e risco que lhes são associados, de modo a orientar decisões relativas à distribuição de recursos e à definição de prioridades. São ainda mais raros estudos que possam informar sobre a maneira como as pessoas idosas residentes no Brasil tentam dar significado a esse período de suas vidas e sobre a forma como limitações e perdas (freqüentes nessa fase da vida) são integradas à experiência de vida. Muito pouco se conhece sobre a maneira como essas pessoas percebem seus problemas de saúde e agem diante deles ou quais são os fatores (econômicos, sociais e culturais) que podem influenciar percepções e ações nesse campo.

Para ultrapassar o estado atual de conhecimentos, é preciso levar-se em conta que o envelhecimento é vivido de modo diferente de um indivíduo para outro, de uma geração para outra e de uma sociedade para outra. Essa diversidade de experiências nos convida a distinguir entre os elementos intrínsecos ao processo do envelhecimento e aqueles mais diretamente ligados às características do indivíduo, à dinâmica social e às políticas públicas vigentes. Nessa perspectiva, particularidades culturais e processos lógicos predominando em cada contexto emergem como elementos essenciais para a elaboração de políticas mais adequadas às características das populações a serem atendidas.

Estudos antropológicos tornam-se imprescindíveis para investigar as condições de vida dos idosos e identificar os fatores sociais, culturais e econômicos que intervêm positiva ou negativamente na qualidade de vida desta população. Aqui, a abordagem antropológica foi utilizada para investigar os problemas encontrados por mulheres idosas vivendo na cidade de Bambuí (MG), assim como as estratégias por elas desenvolvidas para tentar enfrentá-los.

\section{Uma Abordagem Interpretativa do Envelhecimento}

Objeto ambíguo em nossos sistemas de referência, a velhice foi tratada a partir da segunda metade do século XIX como uma etapa da vida caracterizada pela decadência e pela ausência de papéis sociais (Debert, 1999). Inicialmente delimitado por estudos biológicos e fisiológicos, o envelhecimento foi fundamentalmente associado à deterioração do corpo e, a partir daí, utilizou-se essa mesma grade de leitura para guiar pesquisas focalizando outras dimensões (Corin, 1985). Apenas recentemente, essa visão sobre a velhice como um fato orgânico foi perdendo sua força e a velhice e o envelhecimento passaram a constituir objetos de reflexão da antropologia.

Uma abordagem antropológica das questões relativas à velhice e ao envelhecimento deve, desde o início, situá-las em contextos sociais e culturais específicos. Se- 
gundo Corin (1985), a antropologia deve interrogar sobre o papel de fatos socioculturais mais gerais na construção de uma representação da velhice enraizada nas idéias de deterioração e perda. De acordo com essa autora, trata-se de investigar a interação entre parâmetros culturais, traços individuais e marcadores biológicos na construção de representações da velhice e do envelhecimento.

Duas tendências principais reagrupam os estudos antropológicos sobre o envelhecimento; tendências que são elas mesmas um reflexo da evolução conceitual e metodológica em antropologia (Corin, 1982; Létourneau, 1989). A primeira caracteriza-se por uma abordagem estática dos fenômenos socioculturais. Ela reagrupa estudos, privilegiando a investigação de fatores que determinam a posição social dos idosos em diferentes sociedades e procurando analisar o impacto do desenvolvimento social sobre o estatuto das pessoas idosas (Corin, 1982; Fry, 1980; Keith, 1980; Létourneau, 1989). Nesses estudos, a diminuição do prestígio e a deterioração do estatuto dos idosos foram associadas ao processo de modernização (Cowgill \& Holmes, 1972). A segunda tendência caracteriza-se pelo aparecimento de estudos holísticos; neles, o pesquisador tenta penetrar o interior de uma cultura e descobrir como dados relativos ao envelhecimento são organizados e adquirem significado (Létourneau, 1989; Corin, 1982).

Um conjunto de estudos publicados por Meyerhoff \& Simic (1978) ilustra de maneira exemplar a emergência dessa nova tendência em antropologia. Nele, são analisados os aspectos estruturais, culturais e experienciais do envelhecimento em cinco sociedades distintas. O envelhecimento é abordado, pelos diferentes autores, como um fenômeno universal que gera problemas comuns, mas que podem ser vividos e resolvidos diferentemente nas diversas culturas. Esse conjunto de estudos nos convida a examinar os problemas específicos do envelhecimento e as estratégias adaptativas utilizadas pelos idosos em termos de uma articulação entre as capacidades do indivíduo e os recursos do meio.

Arcand (1989) introduz, em perspectiva similar, uma interessante reflexão sobre o papel dos modelos culturais no aparecimento de problemas ligados ao envelhecimento. Segundo o autor, os cuiva, população indígena da Colômbia, tentam negar, de todas as formas, o envelhecimento que se inscreve na própria natureza do ser vivo. Preocupados com os ideais de igualdade e homogeneidade que estruturam a sua sociedade, os cuiva evitam tudo que possa provocar uma ruptura social. Para Arcand, o modelo cuiva é quase uma inversão do modelo ocidental, no qual a sociedade se dá todos os meios para acentuar a distinção entre as diferentes fases da vida.

Essa segunda tendência na abordagem do envelhecimento coincide com o desenvolvimento da corrente interpretativa em antropologia e, nela, a questão do significado passa a ocupar lugar central. Geertz (1973), que se situa na origem dessa corrente, considera a cultura como um universo de significados que permite aos indivíduos de um grupo interpretar a própria experiência e guiar suas ações. Esta definição ressalta a participação essencial da cultura na construção de todos os fenômenos humanos: percepções, emoções e ações.

Nos estudos construídos nessa perspectiva, a abordagem estática dos fenômenos culturais é substituída por uma abordagem processual. $\mathrm{O}$ envelhecimento não é mais encarado como um estado ao qual o indivíduo se submete passivamente, mas 
como um fenômeno biológico ao qual o indivíduo reage com base em suas referências pessoais e culturais (Corin, 1982; Marshall, 1986, 1987). Esta é a abordagem adotada no presente trabalho.

\section{A Abordagem Metodológica}

Com o objetivo de penetrar no universo das mulheres idosas vivendo em Bambuí, foram utilizados dois métodos complementares de coleta de dados. Em um primeiro momento, foram realizadas entrevistas individuais com dez informantes-chave (dez idosos e dez adultos com idades entre 35 e 45 anos) sobre as condições de vida dos idosos residentes em Bambuí. Buscou-se identificar informantes que, por sua inserção na comunidade, estivessem em situação de falar sobre ela. Em um segundo momento foram reconstruídas 30 histórias de vida com mulheres idosas (60 anos de idade ou mais) selecionadas em função de sua inserção em grupos: dez pertencentes a grupos de terceira idade, dez a grupos religiosos e dez que não pertenciam a nenhum desses grupos.

Nas entrevistas com informantes-chave, foram investigados a percepção das condições de vida dos idosos, a inserção dos idosos no campo familiar, os problemas principais (econômicos, de saúde, afetivos), as estratégias utilizadas para enfrentar estes problemas (recurso aos parentes, amigos, vizinhos ou outros; recurso aos serviços da saúde, recurso aos grupos religiosos, recurso aos grupos de terceira idade) e a percepção das expectativas e dos comportamentos de diferentes categorias de pessoas em relação aos idosos.

Para a reconstrução das histórias de vida, focalizou-se o projeto inicial de vida, a situação atual, a inserção no campo familiar e social e a situação econômica nas diferentes fases da vida, os acontecimentos significativos (transformações decorrentes e estratégias utilizadas), os problemas principais na atual fase da vida (de saúde, econômicos, afetivos) e as estratégias utilizadas para enfrentá-los (recurso a parentes, amigos, vizinhos ou outros; recurso aos serviços médicos; recurso aos grupos religiosos; recurso aos grupos de terceira idade etc.), a percepção das atitudes e dos comportamentos de diferentes categorias de pessoas (parentes, amigos, profissionais, outros) em relação aos idosos, a avaliação do impacto de atitudes e de comportamentos específicos sobre a qualidade de vida e as expectativas quanto à velhice e ao envelhecimento e a avaliação da situação atual.

As entrevistas com informantes-chave foram realizadas pelos autores, e as reconstruções das histórias de vida foram realizadas por uma senhora de 68 anos, líder de um grupo de terceira idade em Belo Horizonte. Todas as entrevistas foram gravadas, transcritas e digitadas. A leitura atenta e sistemática do conjunto de entrevistas permitiu a identificação de algumas categorias organizadoras e a construção de grades de codificação (Corin et al., 1992; Uchôa \& Vidal, 1994). Após a transcrição e informatização de todas as entrevistas, os textos foram marcados no computador com a ajuda do software Qualittat (Demicheli \& Uchôa, 1998), em função de categorias definidas nas referidas grades. A partir daí, as categorias de informação recorrentes 
foram identificadas, e seu conteúdo analisado. Finalmente, foram analisadas as interações entre as diferentes categorias de informação.

\section{RESULTADOS}

No conjunto de entrevistas com os informantes-chave, a velhice e o envelhecimento foram associados a distintos níveis de problemas. No campo da saúde, há referência ao aparecimento das doenças crônicas. Na área econômica, há referência à diminuição da renda e a um concomitante aumento dos gastos, particularmente em função dos problemas com a saúde. Há também referência, em quase todas as entrevistas, ao declínio funcional levando à incapacidade progressiva de exercer as atividades cotidianas e à perda da autonomia. No âmbito das relações sociais, há referência a um comprometimento da inserção social; mortes de parentes e amigos e aposentadoria favorecem a diminuição da rede social, a perda de papéis sociais, a marginalização e o isolamento.

De maneira geral, todos esses problemas convergem para um conjunto de perdas diversas, todas elas implicando um aumento progressivo da dependência e a exigência de diferentes níveis de suporte. Esses são os elementos centrais do discurso dos informantes-chave. A imagem da velhice desenhada por eles é bem negativa: carência afetiva, econômica, inutilidade, dependência, desamparo, marginalização e deterioração da saúde aparecem como elementos constitutivos desta fase da vida.

Quando são focalizadas as histórias de vida, surgem imagens bem mais positivas da velhice e do envelhecimento. Nenhuma das mulheres entrevistadas, sejam quais forem suas características, reconhece seu momento de vida como inteiramente negativo ou definido apenas por perdas e limitações. É preciso ressaltar que o grupo de mulheres entrevistadas é bastante heterogêneo. Treze tinham entre 60 e 69 anos e 13 entre 70 e 80 anos; apenas quatro tinham mais de 80 anos e somente uma mais de 90 . A maioria delas era viúva, com filhos e baixa escolaridade. Dez disseram nunca ter tido filhos, cinco nunca ter se casado e apenas uma afirmou ter feito curso superior. Doze dizem viver com a aposentadoria de um salário mínimo; dez afirmam possuir bens e não ter problemas financeiros; o restante reagrupa situações intermediárias entre esses dois extremos.

D. Joaquina é um senhora de 94 anos que vive acamada há alguns meses. Ela nos conta que quebrou uma perna e dois meses depois quebrou a outra, mas, surpreendentemente, define sua saúde como "muito boa". D. Maria tem 80 anos e diz que sempre teve problemas de coluna e que agora arranjou uma artrose: "Mas nada sério, nunca tive nenhuma fratura e só tomo remédio para fortalecer o coração". D. Norma diz que seu problema é o coração: "Sou ofendida pelo barbeiro e de uns anos para cá tenho um ressecamento na boca, mas eu trabalho, lavo a roupa da casa, passo, passeio muito, como bem, durmo a noite inteira, não preocupo com o que vem lá da frente...”. D. Ana tem 70 anos e conta que tem angina e já fez angioplastia, mas afirma que passa bem porque é obediente e quer "viver muito". Problemas de saúde, em maior ou menor grau, aparecem em quase todos os relatos. Entretanto, a avaliação da 
mas, a aposentadoria representa também para elas um mínimo de autonomia: poder de decidir onde e com o que gastá-la.

O isolamento não é identificado pelas idosas de Bambuí como um elemento constitutivo de suas vidas. D. Joaquina diz que, apesar de viúva, não se sente só. Tem muitos amigos, sempre tem um de seus filhos com ela e uma vez por semana todos os seus filhos se reúnem em seu quarto. D. Maria tem 75 anos e diz que não sai muito por sua opção própria, mas sente-se perfeitamente amparada pela família, com a qual pode contar em qualquer situação: "Se faltar dinheiro, é só falar. Não passo falta de nada. Na doença, eles me acodem. Em festas, sou a primeira a ser convidada”. O papel da família é também aqui apontado como fundamental, mas as associações comunitárias ou religiosas têm igualmente um papel muito importante.

Em vários relatos, é possível identificar uma busca ativa de redes de solidariedade extrafamiliares. D. Ana afirma que "quem mora sozinha tem que agradar as pessoas". Ela diz não se esquecer disso e ter sempre gente por perto. A cada dia da semana, ela participa de uma atividade comunitária. Vê muitas pessoas e tem muitos amigos. Diz que sua vida é cheia e que se sente feliz. A rotina de D. Vilma também era assim, mas seus problemas de saúde vieram modificá-la: "Ultimamente não posso andar. Não sirvo para ficar em qualquer lugar. Então eu fico mais é em casa”. A vida de D. Aparecida também mudou bastante depois que teve um derrame e suas idas à igreja foram interrompidas. De maneira geral, a participação nos grupos de terceira idade ou outras associações comunitárias é vista como um verdadeiro "remédio contra o isolamento", mas para participar é preciso ter saúde.

Analisando a relação entre projeto inicial e situação atual, é possível enquadrarmos o conjunto de histórias de vida em três subgrupos. Em um primeiro grupo, o projeto inicial foi perfeitamente realizado: "Eu sonhava ter uma casa com um quintalzinho para plantar. Com toda a luta, com todo o sofrimento, eu hoje tenho o que sonhei". Em um segundo grupo, a situação atual contradiz o projeto inicial: "A única coisa que eu queria era casar e ter filhos. Hoje eu sou solteira, mas minha vida é boa”. E em um terceiro grupo, o projeto inicial foi totalmente modificado: "Meu ideal era estudar... Meus projetos foram modificados. Casei e logo comecei a criar família".

Entretanto, não é possível estabelecer uma correlação precisa entre qualquer um dos padrões (realização, contradição e modificação) e uma avaliação mais ou menos positiva da própria vida. Parece ser mais na capacidade de superar eventos dolorosos, redefinir prioridades e integrar mudanças do que no alcance de uma meta preestabelecida que se fundamenta uma avaliação positiva. Não é incomum, mesmo nos casos em que há contradição entre o projeto inicial e a situação atual, que as mulheres bambuienses definam a terceira idade como a melhor fase de suas vidas.

A análise dessas histórias deixa claro que existe uma relação extremamente complexa entre os vários níveis de problemas identificados pelas mulheres idosas e as estratégias por elas desenvolvidas para enfrentá-los. Nos exemplos citados, fica claro que um problema de saúde pode ser exacerbado ou minimizado pela inexistência ou existência de suporte familiar ou comunitário, ou que a situação financeira pode exacerbar ou aliviar as conseqüências de um problema de saúde. Assim, parece ser constitutiva da própria definição de problema a existência ou não de recursos para solucioná-lo. 


\section{Conclusão}

A análise do conjunto de entrevistas realizadas aponta para uma diferença marcante entre o discurso dos informantes-chave sobre a condição de vida dos idosos de Bambuí e o discurso das mulheres bambuienses sobre suas próprias vidas. Para a grande maioria dos informantes-chave, ser velho significa ser só, viver precariamente, ser inútil, dependente, desamparado, marginalizado e doente. Nenhuma das mulheres bambuienses se reconhece nesse discurso. O conjunto de suas histórias de vida mostra, ao contrário, que perdas e limitações existem, mas que isto não é específico da velhice e que, além disso, o impacto real de tais perdas pode ser mediado por diferentes elementos do contexto.

A confrontação entre os dois tipos de dados analisados opõe de maneira radical a definição externa e negativa do envelhecimento que é dada pelos informantes-chave e a maneira pela qual as mulheres idosas de Bambuí tentam atribuir significado a este período de suas vidas. Também fica evidente a oposição entre o caráter homogeneizador que marca o discurso dos informantes e a heterogeneidade de experiências que caracteriza as histórias de vida.

Corin (1985) explicita claramente a relevância dessa situação, chamando a atenção para a conjugação entre parâmetros externos (socais e culturais) e internos na construção de uma relação individual com o envelhecimento. Assim, uma definição cultural de velhice descrita em termos negativos (perda, falta do que é valorizado socialmente) imporia do exterior uma certa marginalização às pessoas idosas. Segundo a autora, seria igualmente a partir dessa idéia de perda (de papéis sociais, de capacidades intelectuais) que se estruturariam os programas destinados aos idosos. GognalonsCaillard (1979) sugere que essa acentuação da visão deficitária do envelhecimento, que predomina no Ocidente, estaria ligada à maneira pela qual a velhice se situa na contracorrente de uma sociedade centrada na produção, no rendimento, na juventude e no dinamismo.

Nos últimos anos, uma perspectiva crítica e, sobretudo, a adoção de uma abordagem holística do envelhecimento favoreceram a emergência de um consenso sobre a necessidade de "quebrar preconceitos" (Veras, 1997), "rever estereótipos" (Debert, 1999), "abandonar pressupostos" (Sant'Anna, 1997) ou, mais precisamente ainda, "desconstruir a velhice" (Guedes, 1999). Nesse contexto, passa-se a interrogar a atitude alarmista e seu fundamento básico: uma visão negativa e homogeneizadora do envelhecimento. Surge, então, em torno da noção de terceira idade, um movimento de transformação de representações e práticas relativas à velhice e ao envelhecimento. E, certamente, serão as iniciativas se inserindo nesse movimento que contribuirão para uma transformação da realidade de todos os dias e, com ela, das representações da velhice e do envelhecimento.

Entretanto, Debert (1999) chama a atenção para os perigos inerentes à exacerbação desta tendência contemporânea e seu papel nos "processos de reprivatização" da velhice. Para a autora, a idéia de que a eterna juventude é um bem que pode ser conquistado e é a base de algumas iniciativas e práticas destinadas aos idosos que negam a 
velhice, a doença e a morte, transformando-as em responsabilidade individual. Segundo ela, a velhice não deve ser dissociada da doença e da morte. As histórias de vida aqui analisadas também apontam nesta direção: não adianta negar, o importante é integrar todos os recursos disponíveis (individuais e coletivos) em um processo no qual compensação pela incapacidade, redefinição de prioridades e adaptação à situação permitam aos idosos continuar, mesmo quando têm graves problemas de saúde.

\section{ReferênCIAS BibLIOGRÁficaS}

ARCAND, B. La construction culturelle de la vieillesse. In: SANTERRE, R. \& LETOURNEAU, G. (Eds.) Vieillir à Travers le Monde. Québec: Les Presses de l’Université Laval, 1989.

BERQUÓ, E. Considerações sobre o envelhecimento da população no Brasil. In: LIBERALESSO, A. \& DEBERT, G. G. (Orgs.) Velhice e Sociedade. Campinas: Papirus, 1999.

BIRREN, J. E. Aging in America: roles for psychology. American Anthropologist, 85:298-299, 1983.

BLAY, S. L.; MARI, J. J. \& RAMOS, L. O uso do face-hand-test como instrumento para rastrear as síndromes psicorgânicas: estudo piloto. Revista de Saúde Pública, 23:395-400, 1989.

CORIN, E. Regards anthropologiques sur la vieillesse. Anthropologie et Sociétés, 6(3):63-90, 1982.

CORIN, E. Définisseurs culturels et repères individuels: le rapport au corps chez les personnes agées. International Journal of Psychology, 20:471-500, 1985.

CORIN, E. et al. La place de la culture dans la psychiatrie africaine d'aujourd'hui: paramètres pour un cadre de références. Psychopathologie Africaine, 24:149-181, 1992.

COWGILL, D. \& HOLMES, L. (Eds.) Aging and Modernization. Nova Iorque: Appleton Century Crofts, 1972.

DEBERT, G. G. A Reinvenção da Velhice. São Paulo: Edusp, 1999.

DEMICHELI, W. \& UCHÔA, E. Qualittat, versão 2.0, 1998.

DUCHARME, F. Impact du Soutien Conjugal et des Stratégies Adaptatives sur le Bien-être des Conjoints Agés, 1992. Rapport de Recherche, Université de Montréal.

FIBGE - FUNDAÇÃO INSTITUTO BRASILEIRO DE GEOGRAFIA E ESTATÍSTICA. SECRETARIA DE PLANEJAMENTO, ORÇAMENTO E COORDENAÇÃO. Anuário Estatístico do Brasil. Censos Demográficos de 1950, 1991.

FOURNIER, J. Vieillir aux Etats-Unis. In: SANTERRE, R. \& LETOURNEAU, G. (Eds.) Vieillir à Travers le Monde. Québec: Les Presses de l'Université Laval, 1989.

FRY, C. L. (Ed.) Aging in Culture and Society. Nova Iorque: Praeger, 1980.

GEERTZ, C. The Interpretation of Cultures. Nova Iorque: Basic Books Inc. Publishers, 1973.

GOGNALONS-CAILLARD, M. La production sociale de la maladie dans la vieillesse. Gérontologie, 29:21-25, 1979. 
GUEDES, S. L. Dos muitos modos de envelhecer no Brasil: "antropologia do envelhecimento". Arquivos de Geriatria e Gerontologia, 3:86-93, 1999.

KALACHE A. Os idosos na Grande São Paulo. Revista Brasileira de Estudos de População, 7(1):90-96, 1990.

KALACHE, A. Ageing in developing countries. In: PATHY, M. S. J. Principles and Practice of Geriatric Medicine. Nova Iorque: John Wisley \& Sons Ltd., 1991.

KEITH, J. The best is yet to be: toward an anthropology of age. Annual Review of Anthropology, 9:97-106, 1980.

LETOURNEAU G. L'étude comparative du vieillissement. In: SANTERRE, R. \& LETOURNEAU, G. (Eds.) Vieillir à Travers le Monde. Québec: Les Presses de l'Université Laval, 1989.

LIMA-COSTA, M. F. F. et al. The Bambuí health and ageing study (BHAS): methodological approach and preliminary results of a population-based cohort study of the elderly in Brazil. Revista de Saúde Pública, 34(2):126-135, 2000.

MARSHALL, V. A sociological perspective on aging and dying. In: MARSHALL, V. (Ed.) Later Life: the social psychology of aging. California: Sage Publications, 1986.

MARSHALL, V. Social perspectives on aging: theoretical notes. In: MARSHALL, V. (Ed.) Aging in Canada: social perspectives. Ontario: Fitzhenry \& Whitside, Markham, 1987.

MEYERHOFF, B. \& SIMIC, A. (Eds.) Life's Career Aging: cultural variations on growing old. Beverly Hills, Londres: Sage Publications, 1978.

NAJAS, M. S. et al. Padrão alimentar de idosos de diferentes estratos socioeconômicos residentes em localidade urbana da Região Sudeste, Brasil. Revista de Saúde Pública, 28:187-191, 1994.

NEUGARTEN, B. L. The aged in American society. In: BECKER, H. S. (Ed.) Social Problems: a modern approach. Nova Iorque: John Wisley \& Sons, 1967.

RAMOS, L. Growing Old in São Paulo, Brazil: assessment of health status and social support of elderly people from different socioeconomic strata living in the community, 1986. Ph.D. Thesis, Londres: London School of Hygiene and Tropical Medicine.

RAMOS, L. \& GOIHMAN, S. Geographical stratification by socio-economic status: methodology from a household survey with elderly people in S. Paulo, Brazil. Revista de Saúde Pública, 23:478-492, 1989.

RAMOS, L. R. et al. Perfil do idoso em área metropolitana na Região Sudeste do Brasil: resultado de inquérito domiciliar. Revista de Saúde Pública, 27:87-94, 1993.

SANT'ANNA, M. J. G. Unati, a velhice que se aprende na escola: um perfil de seus usuários. In: VERAS, R. P. (Org.) Terceira Idade: desafios para o terceiro milênio. Rio de Janeiro: Dumará, 1997.

UCHÔA, E. \& VIDAL, J. M. Antropologia médica: elementos conceituais e metodológicos para uma abordagem da saúde e da doença. Cadernos de Saúde Pública, 10(4):497-504, 1994.

UNO - UNITED NATIONS ORGANIZATION. DEPARTMENT OF INTERNATIONAL ECONOMIC AND SOCIAL AFFAIRS. The World Aging Situation: strategies and policies; technical report. Nova Iorque, 1985. 
VERAS, R. P. et al. Proposta metodológica para inquérito domiciliar com populações idosas em um centro urbano do Estado do Rio de Janeiro (Brasil). Revista de Saúde Pública, 23:429438, 1989.

VERAS, R. P.; COUTINHO, E. \& NERY JR., G. População idosa no Rio de Janeiro (Brasil): estudo piloto da confiabilidade e validação do segmento de saúde mental do questionário BOAS. Revista de Saúde Pública, 24:156-163, 1990.

VERAS, R. P. \& COUTINHO, E. Estudo de prevalência de depressão e síndrome cerebral orgânica na população idosa em três distritos da cidade do Rio de Janeiro. Revista de Saúde Pública de São Paulo, 25:209-217, 1991.

VERAS, R. P. \& MURPHY, E. The ageing of the Third World: tackling the problems of community surveys. Part II: A community survey of the elderly population in Rio de Janeiro: a methodological approach. International Journal of Geriatrics and Psychiatry, 6:619-627, 1991.

VERAS, R. P. A. Survey of the Health of Elderly People in Rio de Janeiro, Brazil, 1992. Ph.D. Thesis. Londres: United Medical \& Dental Schools, Guy's Hospital, Division of Psychiatry, University of London.

VERAS, R. P. Apresentação. In: VERAS, R. P. (Org.) Terceira Idade: desafios para o terceiro milênio. Rio de Janeiro: Dumará, 1997.

VERAS, R. P.; COUTINHO, E. \& COELI, C. M. Transtornos mentais em idosos: a contribuição da epidemiologia. In: VERAS, R. P. (Org.) Terceira Idade: desafios para o terceiro milênio. Rio de Janeiro: Dumará, 1997.

WATERS, W. E.; HEIKKINEN, E. \& DONAS, A. S. (Eds.) Health, Lifestyles and Services for Elderly. Copenhague: World Health Organization, 1989. (Public health in Europe, 29) 


\title{
2 \\ Envelhecimento e Sentimento do Corpo
}

\author{
Alda Britto da Motta
}

\section{INTRODUÇÃO}

Provavelmente, a maior parte dos estudos sobre o envelhecimento e a velhice, pelo menos no Brasil, refere-se ao campo da saúde e áreas correlatas. Ao mesmo tempo, a impressão que tenho é de que se fala ainda pouco sobre processos testados, resultados de pesquisa, e não se chega a um nível suficiente de concretude, nem se alcança o ângulo de conexão com os 'envelhecentes'. A sensação é de encontrar neles corpos classificatoriamente naturais, ao mesmo tempo simbolicamente descorporificados e mudos. Certamente por isso, a promessa de algo novo é a sensação que me proporciona uma oficina de antropologia, saúde e envelhecimento.

Que posso oferecer nela? Reflexões resultantes de estudos e pesquisas, empreendidos nos últimos seis anos, sobre esse heterogêneo segmento social que são os idosos. Teoricamente, essa heterogeneidade remete necessariamente a uma definição de categorias de análise mais determinantes e elucidativas nos sistemas de relações sociais gênero, idade/geração e classe social - em suas especificidades e também mútuas articulações. Há, ainda, outras que remetem diretamente ao âmbito dos modos de vida, interesse central nos projetos, tais como vivências, experiências e representações.

No que concerne à metodologia, trabalhei em anos anteriores na documentação e na análise das atividades, em programas ou grupos 'de convivência', de idosos 'jovens' (até 75 anos), de ambos os sexos e diferentes classes sociais, em Salvador, com atenção tanto aos modos de vida das pessoas como às propostas de organização dos grupos e à forma como os idosos se situam neles.

Foram quatro diferentes tipos de grupos: três organizados e um altamente informal. Um congregando pessoas de camadas médias e altas da sociedade; os outros reunindo idosos das classes populares.

Esses grupos, em suas atividades e pausas entre elas, também constituíram o foco de observação direta, participante quando houve a possibilidade, com registros em diário de campo, além de longas entrevistas individuais feitas nos locais dos encontros, em número próximo de cem. 
No momento, em outro projeto, acompanho, num movimento exploratório, os mais velhos, com idades em geral muito superiores a 80 - agora individualmente, em suas casas, onde a observação e as entrevistas estão sendo feitas. Homens e mulheres de diversos estratos sociais. O trabalho ampliou-se no segundo semestre de 2001, para permitir uma base comparativa entre a condição social e existencial dos mais 'jovens' e a dos de idade mais avançada e, se possível, quebrar um pouco do mistério que cerca os muito velhos.

\section{Velhice, natureza e cultura}

Da mesma forma como sempre as mulheres foram ligadas à 'natureza', como forma de dominação e controle - e toda a fase inicial do feminismo dos anos 60/70 foi um enorme movimento de esclarecimento e recusa a esse determinismo bioideológico -, assim ainda é feito com 'os velhos'. Mas de maneira diferente - e pior. É como se eles estivessem numa dimensão não produtiva e terminal da natureza - resíduos da natureza, objetos de necessário descarte. Não se reproduzem mais, não produzem trabalho e bens materiais (ou não se permite que produzam, segundo os cânones do capitalismo). Em suma, não reproduziriam a sociedade. Portanto, 'não pertencem' a ela. Até o ponto da análise de Birman (1995:43), "este lugar impossível que a modernidade ocidental construiu para a velhice, (...) [onde] a individualidade deixa de existir".

A modernidade capitalista construiu uma visão segmentar das idades: periodiza as gerações, constrói e 'desconstrói' 'idades', quase a cada século inventa mais uma. Primeiramente a infância e a juventude, no pré-capitalismo socialmente indiferenciadas da idade adulta (Ariès, 1978); bem mais recentemente (década de 60), inventa uma 'terceira idade', inserção de um novo período entre a maturidade e a velhice, ao mesmo tempo negação desta (Lenoir, 1979).

Em seguida, logo reconhecida a incapacidade de dar conta da atual longevidade dos mais velhos, talvez afastada da imagem, atualmente idealizada, dos idosos dinâmicos e alegres dos grupos de 'terceira idade', inventa-se uma inescapável 'quarta idade', prenunciadora ainda de uma quinta... E estas, quase ninguém quer estudar ou conhecer...

Entretanto, a ainda majoritária terceira idade começa a ser muito lucrativa para uma série de organizadores/gestores de atividades, produtos e serviços para esta faixa etária - que, entre programas de lazer que incluem cursos, festas e viagens para uma 'velhice saudável', "põem em circulação o dinheiro dos velhos" - como expressou, de modo severo, Ariès (1993:53) - mas, contraditoriamente (e felizmente) põem também em circulação social os próprios velhos, grande parte deles 'sem lugar' na sociedade contemporânea. Repõem-nos, porém, nos interstícios dela (Britto da Motta, 1998, 1999b). E ao mesmo tempo deixam neles a sensação de estar mais vivos e, às vezes, alegres.

No cotidiano, entretanto, as 'idades' ainda são percebidas principalmente como parte do passar do tempo, mimetizando como duração e ritmo os ciclos da natureza e as 
estações, o que é expresso no corpo das pessoas. Diz-se completar 'quinze primaveras', estar 'na flor da idade' ou 'ainda viçosa aos 50 anos', 'bem conservado(a)', 'no inverno da vida' etc. Expressa-se um tempo 'da natureza' em trajetórias pelo mundo da cultura no capitalismo.

Se a atuação do indivíduo deixa de corresponder à classificação bioetária socialmente esperada, dá-se um ‘escândalo lógico’ e, adiante, o ‘infrator' será punido. Com remissões de cruel mau gosto, como "está conservado(a) em formol”, com o ridículo ("velhas peruas") ou a censura. A própria literatura veicula imagens cruéis da velhice, especialmente a das mulheres. García Márquez (1987:317) é um exemplo, num livro que fala de amor:

Os homens floresciam numa espécie de juventude outonal, pareciam mais dignos com as primeiras cãs, se tornavam engenhosos e sedutores, (...) enquanto que suas murchas esposas tinham que se aferrar ao braço deles, para não tropeçarem até na própria sombra.

Repare-se nas metáforas sazonais e no 'castigo', que é sempre diferente segundo o sexo/gênero: "Poucos anos depois, no entanto, os maridos despencavam (...) no precipício de uma velhice infame do corpo e da alma...” (García Márquez, 1987:317).

O livro inteiro é, na verdade, um libelo contra a velhice, como destruidora do corpo e da 'alma'. O personagem médico, de forma escondida e inútil, leva adiante sua luta pessoal:

Levantava-se com os primeiros galos, e a essa hora começava a tomar seus remédios secretos: brometo de potássio para levantar o ânimo, salicilatos para as dores dos ossos em tempo de chuva, gotas de cravagem de centeio para as vertigens, beladona para o bom dormir. Tomava alguma coisa a cada hora, sempre às escondidas, porque em sua longa vida de médico e mestre foi sempre contrário a receitar paliativos para a velhice: achava mais fácil suportar as dores alheias que as próprias. (García Márquez, 1987:321)

A referência à imagem do corpo, no entanto, pode ser a mais dura:

Atreveu-se a explorar com a ponta dos dedos seu pescoço flácido, o peito encouraçado de varetas, as cadeiras de ossos carcomidos, as coxas de corça velha... Tinha os ombros enrugados, os seios caídos, e as costelas forradas de um pelame pálido e frio como o de uma rã. (García Márquez, 1987:417)

É evidente que essa aproximação desmesurada que se faz do velho com a natureza não corresponde a uma integração social/natural ou a uma superação da dicotomia corpo/espírito da cultura ocidental, mas, ao contrário, a um alargamento de fosso que torna a 'natureza' 'unipresente' e 'final'.

A cultura, no entanto, também está inscrita no corpo, ao mesmo tempo condicionando e transformando a natureza. Não atua, sabemos, de modo homogêneo no interior de uma sociedade e em determinado período histórico. É conformada por determinados sistemas de relações sociais em seus modos de realização, que se constituem, ao mesmo tempo, em dimensões básicas da vida social e da sua análise, como as relações de classe, de gênero e entre as gerações (Britto da Motta, 1999a). 
Por isso, os corpos, além de sua forma e 'natureza' humana, diferenciam-se em cada período histórico no seu existir biossocial - como corpos de homem ou de mulher, de jovem ou de velho - e de classe social, com diferentes práticas.

Boltanski analisa, como expressão geral, o corpo em sua percepção e uso conforme a situação de classe:

À medida que se sobe na hierarquia social, que cresce o nível de instrução e que decresce correlativamente e progressivamente o volume de trabalho manual em favor do trabalho intelectual, o sistema de regras que regem a relação dos indivíduos com o corpo também se modifica: quando sua atividade profissional é essencialmente uma atividade intelectual, não exigindo nem força nem competência física particulares, os agentes sociais tendem primeiramente a estabelecer uma relação consciente com o corpo e a treinar sistematicamente a percepção de suas sensações físicas e a expressão de suas sensações... (Boltanski, 1979:168)

Esse autor analisa também um aspecto interessante - mas ainda motivo de muita discussão - da situação de gênero: as mulheres, que teriam "um consumo médico maior do que os homens", consomem também mais produtos farmacêuticos; queixam-se mais do que os homens de perturbações digestivas, "dores indeterminadas", enxaquecas e outras “doenças vagas"; "escutam-se mais do que eles, da mesma maneira que os membros das classes superiores se escutam mais facilmente que os membros das classes populares e mantêm, mais freqüentemente do que os homens, uma relação sensitiva com o corpo" (Boltanski, 1979:174).

Há, entretanto, outras dimensões ou nuances das relações sociais e ligadas não apenas ao gênero, que não podem ser analisadas mais amplamente senão como relações e socializações ligadas ao poder social - são, sobretudo, as idades/gerações. No exercício desses mecanismos de poder social (Bourdieu, 1983), constroem-se preconceitos que têm mais diretamente a ver com a disputa, entre as idades, pelos postos de trabalho no mercado, mas também, e em outro extremo, com a aversão possível aos que, já mais velhos, não possam manter as competências sociais de controle corporal: "Degrees of loss impair the capacity to be counted as a competent adult..." (Featherstone, 1991:376) e, não por último, o medo ou recusa à idéia de morte... E de quem, em princípio, está mais perto dela (Britto da Motta, 1998).

Todos esses diferenciais referem-se, evidentemente, aos corpos em suas múltiplas manifestações ou expressões: linguagem, apresentação física (roupas, penteados, pintura, adereços), gestos etc.

O 'gestual humano', por exemplo, como ação biocultural - postura do corpo e meio de comunicação instantânea -, é particularmente diferente segundo idades e gerações. No caso dos idosos, isso é enfatizado; o comportamento corporal é demandado de fora, para que se coadune com o modelo cristalizado do preconceito social. Deles não se espera vigor, leveza nem dinamismo. Até os próprios velhos entram nesse ageism, embora, atualmente, cada vez mais resistam a ele. Maria Pureza, de 61 anos, participante de uma associação de bairro, define 'velho' segundo esse modelo tradicional e por isso não se reconhece nele: 
Velho é uma pessoa que anda assim... [Curva o corpo.] Eu sou uma mulher de idade. [Endireita o corpo, olhando para a frente.]

Osvaldo, 62 anos, de uma faculdade da terceira idade, reage:

Encontramos barreiras impostas pela própria sociedade, que diz que você já está velho para determinadas coisas. Você não pode brincar ou ter expressões corporais, que logo dizem: 'Que velho gaiato!' 'Isso não é coisa de velho!'

Às vezes as pessoas fazem concessões e expressam um esteticismo abstrato, comentando a beleza de um rosto "marcado pelo tempo", "um pergaminho". Mas ninguém quer ter essa 'beleza', essa aparência associada ao desgaste e à proximidade da morte.

No imaginário social, o envelhecimento é um processo que concerne à marcação da 'idade' como algo que se refere à 'natureza', e que se desenrola como desgaste, limitações crescentes e perdas, físicas e de papéis sociais, em trajetória que finda com a morte. Não se costuma pensar em nenhum bem; quando muito, alguma experiência. Nenhum ganho, nessa 'viagem ladeira abaixo'.

As perdas são tratadas principalmente como problemas de saúde, expressas em grande parte na aparência do corpo, pelo sentimento em relação a ele e ao que lhe acontece: enrugamento, encolhimento, descoramento dos cabelos, 'enfeiamento', reflexos mais lentos, menos agilidade... Mas são expressas muito mais pelos outros do que pelos próprios velhos.

Há, naturalmente, da parte dos próprios idosos, a clara percepção desse processo - tanto o do corpo como o da reação social a ele. Existem queixas, moderadamente, ou a referência à 'normalidade' do que acontece, principalmente em relação a dores - na coluna, nas pernas, 'nos quartos', nos braços... Há, também, quase uma 'naturalidade' sobre isso, e não apenas nas classes populares, entre os menos assistidos. $\mathrm{O}$ ator Paulo Autran, em recente entrevista a um programa de televisão e em meio a animados comentários sobre seu mais novo trabalho, definiu: "Ser velho é sentir uma dor a cada dia".

Essas referências à dor ou a problemas de saúde, nas entrevistas que fiz, são sempre matizadas por um certo fair-play, uma 'filosofia do cotidiano' - 'isso é da velhice' - que alcança até o limite da ambigüidade. Vejam-se D. Marta, 72 anos, e o Sr. Manoel, 73. São ativos e participam de grupos de idosos. Eles falam sobre o sentimento da 'idade':

Eu quase morri, e vivi. Depois tomei muito remédio. Agora me acho feliz da vida. Não fico mais doente, só gripe. O que me ataca mais é a coluna. (D. Marta)

Eu senti e sinto, cada dia mais. A gente sente aquele desânimo no corpo. Eu me sinto tão alegre que não pensei que ia viver tanto. (Sr. Manoel)

Surpreendentemente, os de idade mais avançada também não têm grandes queixas. Mesmo o Sr. Pedro, com 100 anos e uma perna quebrada, conta que viveu bem e é feliz. D. Brígida revela que só se deu conta da 'idade' aos 95 anos, quando começou a ter tonturas. Até então, trabalhava com a enxada. Curiosamente, a que relata mais sintomas é a vigorosa e incansável D. Lalu:

A gente sente dores nos braços, na coluna, a pressão vai ficando alta, dores nas pernas, a gente sente que é uma droga! 
Deu-me a impressão de que falava não por si, mas por um coletivo. Suas palavras pareciam bem distanciadas das minhas anotações no diário de campo, porque, ao conhecê-la, eu havia anotado: "É uma senhora de ótimo porte, aparentando bem menos que os seus 86 anos". E ao fim do dia que passei em sua casa:

Saímos, logo depois do almoço, para a gruta, onde ela vai cerca de duas vezes por dia. É um percurso razoavelmente longo e enladeirado, muitos sobe-e-desce, que ela percorreu bem, andando na frente, sem demonstrar qualquer cansaço, enquanto os mais moços ficavam de fôlego curto e pernas, em alguns momentos, reclamando...

Que resistência têm os idosos diante dos limites e perdas? Por um lado, essa naturalidade assinalada e, por outro, uma dissociação até certo ponto confortadora:

As pessoas, principalmente as das classes populares, estão sempre diferenciando corpo e mente, corpo e sentimentos, atordoadas pelo fato de que as perdas e limitações se dão primeiro na aparência e pequenas diminuições de possibilidades físico/funcionais do corpo, enquanto 'por dentro eu ainda sou a mesma'.

São muitos os depoimentos desse teor nas minhas pesquisas. Vários outros são relatados por Beauvoir (1980), como também reunidos por Featherstone (1991), que propõe a expressão 'máscara do envelhecimento' (mask of ageing) para ilustrar uma situação e um sentimento, muito generalizados, de se ter uma espécie de máscara imposta ao corpo que esconderia a identidade mais profunda da pessoa, a qual continuaria sendo essencialmente a mesma da juventude.

Um depoimento especialmente expressivo de tal estranhamento foi recolhido, ainda por Featherstone, do escritor inglês J. B. Priestley, aos 79 anos:

É como se, descendo a Avenida Shaftesbury como um homem jovem, eu fosse subitamente raptado, arrastado para um teatro e obrigado a receber o cabelo grisalho, as rugas e outras características da velhice, e empurrado para o palco. Atrás da aparência da idade eu sou a mesma pessoa, com os mesmos pensamentos de quando eu era mais jovem. (Featherstone, 1991:379)²

Esse sentimento, nada incomum, demonstra bem a dificuldade de construção da identidade de velho. Se a formação das identidades de idade ou de geração já é difícil, porque são condições mutáveis rapidamente no tempo - a cada ano se tem uma nova idade; a cada dez ou vinte anos se é classificado numa outra geração (Britto da Motta,1999a) -, pior a fixação da identidade de velho, porque indesejada e dúplice, ou ambígua, principalmente quando referida ao corpo: a aparência 'desgastada', seu funcionamento não totalmente sincronizado e a mente - ou a essência dos sentimentos - 'jovem'.

Um equilíbrio difícil, que me leva a propor ampliar a enunciação de Ferreira, segundo quem "É no campo relacional que se estabelecem os limites entre juventude e velhice (...) Pensar-se a si próprio é, na velhice, um duplo exercício, pois à medida que o sujeito se define, o faz por contraste com o outro" (Ferreira 1995:429). Diria eu: também com aquele 'outro' que é o seu eu jovem.

Curiosamente, é também o recurso à máscara, desta vez 'da juventude', que encontro expresso na experiência de campo, quando uma mulher relata, indignada, o 
repetido abuso, por parte dos motoristas de ônibus, em Salvador, de não pararem no ponto quando quem nele está é um idoso.

Queria ter uma máscara, uma máscara de jovem, para que ele parasse. Aí [acompanha a fala com os gestos] eu retirava a máscara e lhe 'dava' língua...

É ainda Featherstone (1994:50) que, em outro trabalho, lembra que "a construção das identidades depende da construção das imagens do corpo”.

Fecha-se o ciclo...

No campo científico, as expressões podem não ser muito diferentes daquelas do cotidiano. Os corpos são, cada vez mais, loteados pelas especialidades médicas e afins, segundo aparelhos e sistemas fisiológicos... E idades. O corpo dos velhos é o corpo 'diferente', comparado - em desvantagem - com o modelo de corpo e beleza jovens vigente na sociedade, manipulável para se aproximar deste. Uma série de profissionais cuida desse aspecto: 'alimentação saudável', exercícios físicos, ainda mais eficazes se realizados 'sob orientação especializada' em academias ou com um personal trainer, dança de salão, moda mais jovem etc.

Também é objeto de atenção e especulação o fato de que não se envelhece de modo homogêneo, nem de vez (Britto da Motta, 1998). Dalva, uma senhora que se aproximava dos 60 anos, colecionou, sempre com sentimento de estranheza, esse rol modelar de segmentadas considerações médicas sobre seu corpo, num período de três anos:

Que beleza! Seu joelho tem 20 anos! (Ortopedista olhando, encantado, uma radiografia)

Sua mama! A senhora já fez plástica? Não? Mas está muito bem! (Primeiro ginecologista)

Sua mama é de uma mulher de 40 anos! (Segundo ginecologista)

Sua tensão é de broto! A vagina... tem sua idade. Seria bom fazer reposição hormonal... (Terceiro ginecologista)

Claramente saudável, ainda assim não escapou da projeção do modelo da juventude, do traçado da trajetória cronológica, nem da sugestão de intervenção também 'adequada' à idade.

Contudo, essa percepção segmentada não é simplesmente 'pós-moderna', social e sem motivação existencial direta. A vida é curta e as mudanças corporais se processam rapidamente, por isso, há sempre um sentimento de brusquidão na (auto)percepção do envelhecimento. Ao mesmo tempo, o envelhecimento, como anteriormente mencionado, não se processa de modo homogêneo - nem cronológica, nem física, nem emocionalmente (Debert, 1988; Britto da Motta, 1998). Há sempre partes, órgãos ou funções do corpo que se mantêm muito mais 'jovens', 'conservados' ou sadios do que outros. Assim como no terreno dos sentimentos e das representações, "a velhice nunca é um fato total. Ninguém se sente velho em todas as situações” (Debert, 1988:62). Nem diante de todos os projetos. A literatura tem a clara percepção disso, que Marina Colasanti expressa na dimensão do poema: 


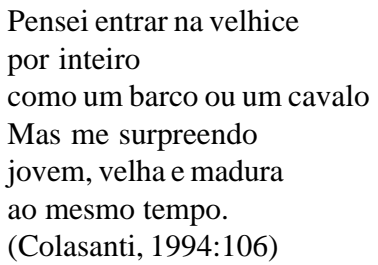

D. Georgina, de uma associação de moradores, também afirma, poeticamente:

Nem me lembro que tô velha. Chego no espelho, vejo minha cabeça [branca], minhas pelanca, mas por dentro eu converso com as meninas da minha rua.

O maior aliado do preconceito contra os velhos pode vir, mesmo, das assertivas e prescrições 'científicas'. Se por um lado há o discurso teórico de médicos mais lúcidos de que velhice não é doença; se Veras (1994), por exemplo, afirma ter encontrado, em sua pesquisa no Rio de Janeiro, uma população idosa em que mais de $80 \%$ são saudáveis; por outro lado, encontra-se, a cada passo, o discurso explícito da doença ou da(s) perda(s) como próprias da velhice. Sugerido, ou posto de fora, é incorporado frequientemente pelos idosos como expectativa de processo ou até acontecimento inarredável. Gomes (1997) fez ilustrativo estudo de uma situação dessas, com idosos atendidos em um ambulatório de geriatria, em Salvador.

Todos referiam-se à 'perda da memória', mas nenhum apresentava distúrbios orgânicos que justificassem a queixa. A pesquisa revelou a expectativa medrosa do esquecimento como 'normal' na velhice, até o ponto de nenhuma falha, nenhum esquecimento, comum em qualquer idade, poder passar com tranqüilidade. Trabalhos em grupo, jogos e exercícios mnemônicos devolveram muito da autoconfiança perdida.

Não se pretende ignorar as diferenças fisiológicas reais do corpo do idoso, em comparação com o dos jovens, mas não raro se exageram as diferenças, que nem sempre pesam muito para o negativo. Em participação observante em oficina 'para a terceira idade' na Escola de Dança da UFBa, acompanhei, durante um mês de férias, outro experimento bem-sucedido - no qual, como costuma acontecer nos grupos, os homens não estavam. Vi os agradecimentos e o suave chorar de saudade de uma convivência e um trabalho estimulantes, em que fora possível a descoberta de que o corpo respondia a movimentos de que já não se julgavam capazes. E não por enfermidade, mas porque era a expectativa 'normal'.

O velho - e seu corpo - é também visto como desvalido, eterna clientela para as técnicas da assistência social. Embora comece a mudar esse tipo de atitude, dela ainda se encontram expressões flagrantes e fortes, até no campo educacional, freqüentemente informado por preceitos da gerontologia, a exemplo da Proposta para a Universidade da Terceira Idade da PUCCamp. Se aí o idoso já não aparece como desvalido, mas como alguém capaz de participar da sociedade, ao mesmo tempo o perfil traçado é, mais que tradicional, desanimador: "discriminado, inativo, vivendo em condições precárias e situação de perda" (PUCCamp, 1991:11). O que tem sido também, por muito tempo, o discurso do Estado e dos criadores e gestores das políticas públicas, muitos deles também gerontólogos. 
Pesquisa realizada em Campinas por Guerrero (1994) sobre a referida 'universidade' chega, entretanto, a conclusões bem mais otimistas:

A Universidade para a $3^{a}$ Idade mobiliza um público que se apresenta como muito ativo. (...) Estamos muito distantes do idoso em crise, solitário, inativo, vivendo em condições precárias (...) tal como (...) é tratado na Proposta de Ação [da PUCCamp]... (Guerrero, 1994:50)

Nas próprias ciências sociais, em pioneiros trabalhos sobre a velhice, ainda se pontuou essa desvalia, mesmo no belo e profundo estudo de Ecléa Bosi: "A mulher, o negro, combatem pelos seus direitos, mas o velho não tem armas. Nós é que temos de lutar por ele" (Bosi, 1987:39).

Diante de perspectivas desse tipo, os velhos não teriam qualquer dinamismo ou poder. Sequer gestão do próprio corpo.

Mas o momento, agora, começa a ser outro. Há todo um processo de mudança em curso, como já estamos vendo.

De forma nada surpreendente, as referências ao envelhecimento e ao corpo são, ainda quando não explícitas, feitas sobretudo às mulheres. Não apenas porque, do ponto de vista da idade, no curso da vida, elas vão-se tornando bem mais numerosas que os homens (60\% a $80 \%$ da população idosa, dependendo do estágio de envelhecimento e do país em questão e apesar de o estresse contemporâneo contribuir para aproximar essas cifras), mas principalmente porque do ponto de vista do gênero as mulheres sempre foram, tradicionalmente, avaliadas pela aparência física e pela capacidade reprodutiva. Em suma, pelo estado do seu corpo: pela beleza que possa exercer atração, pela saúde que permita reproduzir, pela docilidade de um corpo que se deixe moldar para tudo isso e também pela domesticidade, objeto permanente de gestão social. Na velhice, muitos desses circuitos se perdem e elas se sentem, declaradamente, mais livres (Britto da Motta, 1997, 1998) (embora, na sociedade de consumo, eles retornem, tentem retornar à consideração e à ação dos 'especialistas').

Se é verdade que as novas gerações já começam a ter diferentes vivências sociais - do corpo mais livre à experiência amarga e prematura da 'inatividade', do desemprego -, os corpos de quem tem mais idade estão ainda mais diretamente manipulados pelas estranhas estruturas da reprodução capitalista - descartados como força de trabalho e pretensamente dessexuados, mas teimosamente sexuados; trabalhando (às vezes não reconhecidamente) e movimentando-se, hoje resistem.

Movimentam-se, homens e mulheres, em sentidos diferenciados, conforme suas trajetórias de vida: os homens, para o lazer e o ‘descanso' (Britto da Motta, 1997) ou, em bem menor número, para atividades públicas políticas, principalmente o movimento dos aposentados (Pereira et al., 1992; Simões, 1994); as mulheres, para atividades de mais clara liberação existencial, de lazer e cultura (Debert, 1994; Britto da Motta, 1998). Mas todos tendo, em comum, a intensificação ou retomada de uma universalmente desejada sociabilidade (Britto da Motta, 1999b; Peixoto, 1997).

Nesse movimentar-se, seu uso do corpo é retomado em bases mais plenas. Numa aparente contradição, saem do aprisionamento da 'natureza' socialmente (im)posta para - aí, sim! - usarem, ou pelo menos representarem, o corpo de maneira mais natural 
ou - até o ponto em que a cultura ocidental permita - menos fragmentada: andam, dançam, alegram-se (Britto da Motta, 1997).

Mas em novo processo contraditório, são também instados a submeter o corpo às já referidas 'técnicas corporais' (Mauss, 1974) de ginástica e 'alimentação adequada' para alcançar uma 'velhice sadia' ... e uma participação privilegiada no mercado de consumo.

Curiosamente, as especialidades médicas e afins que haviam realizado o já referido 'loteamento' do corpo das pessoas vêm retomando um movimento de ação total sobre esses corpos - não pelo simples retorno do clínico, cuja falta sempre se lamentou, mas, de maneira abarcante, pelo ramo mais recente da geriatria - a qual, aliás, se duplica como espécie de clínica geral, não apenas com freqüência crescente, mas sobretudo porque se espraia em espesso 'receituário' para se viver a velhice 'com qualidade' e com tanto zelo que preconiza as primeiras visitas a partir dos 35 anos... Receituário que vem gerando uma expectativa social compressora sobre os que 'não obedecem', que deveriam sentir-se culpados por estar perdendo a oportunidade de se 'prevenir' do envelhecimento, pois hoje, mais do que nunca, 'só é velho quem quer'...

Há, entretanto, experiências pedagógicas valiosas com idosos, visando a contrabalançar as técnicas de dominação social, como assinalaram Lobato e Mendes (1993), na Escola de Dança da UFBa, ao encontrarem os corpos dos velhos, principalmente de velhas, 'fragmentados' pela imagem social de recusa a eles. Depondo sobre esse exercício reconstrutor, Lobato (1993) detalhou em entrevista:

Com os jovens, se trabalha do corpo inteiro para as partes. Com as idosas, que perdem a imagem do corpo como um todo, por causa da reação da sociedade, se fez o caminho inverso: partimos da parte para o todo; partimos das extremidades. Primeiro os pés, porque pisam e sustentam o corpo, e em seguida as mãos, muito usadas no trabalho.

Os homens não se interessam em participar desses trabalhos, informou Lobato. Preferem reunir-se em outros lugares e atividades, como evidenciou a pesquisa. E em um desses lugares vamos encontrá-los.

Em uma praça de um bairro periférico de Salvador, como em muitas outras praças da cidade, reúne-se diariamente um grupo de homens idosos, quase todos aposentados, para conversar e ver o movimento dos passantes. Ouvi-los é uma oportunidade privilegiada de checar ou superar noções preconcebidas a respeito dos velhos. Num dos bancos dessa praça, jovens pintaram a frase: "Cuidado: banco do pau mole". Os idosos fazem piadas com quem se senta lá (até com o jovem entrevistador da nossa equipe), sem aparentemente estarem preocupados com a pecha, mas nas suas falas, dentro e fora das entrevistas, demonstram estar muito voltados para o sexual (Ribeiro Júnior, 1995). Com alguma tristeza e risos compensatórios, falam sobre as mulheres que já não conseguem conquistar ("Me respeita, velho") como perda. Medem, ainda, suas possibilidades, talvez ampliando-as um pouco:

Sexualmente, dá para três vezes por semana; quando tá jovem, ele quer todo dia. (Antônio, 68 anos)

Referem-se, também, à vida dos outros: 
A mulher daquele ali [aponta] disse: 'Tem mais de cinco anos que não 'dorme' comigo'.

Criticam os companheiros, mas também as mulheres:

O homem, na velhice... se encolhe muito. A mulher quer se 'espalhar', mas não pode. A mulher não se acha velha, fica falando para os outros que os maridos não dão pra nada...

João, 58 anos, vendo a moça bonita que passa, ri:

Ser velho é isso. Só fica olhando.

As idosas, fiéis à trajetória feminina tradicional, costumam silenciar sobre sua sexualidade. Claro, se antes era tabu, se não tinham o hábito dessa confidência, por que se sentiriam à vontade agora?

Instadas a falar, suas declarações são de renúncia ou desesperança:

Eu sou uma senhora de idade, fico no meu lugar. (Maria Pureza, 61 anos)

Já sei o gosto, já me agradei. Mas meu marido era muito ciumento. (...) Eu quero

é poder me divertir... (Augusta, 92 anos)

Hoje eu já tô velha, ninguém olha. (Matilde, 72 anos)

Quando admitem o impulso sexual vivo, freqüentemente o remetem aos laços (indissolúveis até na morte) do casamento:

Se meu velho estivesse vivo, eu estaria funcionando. (Hercília, 85 anos)

É raro este tipo de comentário:

Os homens velhos, em relação ao sexo, estão 'pimba'. Já a mulher, mesmo de bengala, sente prazer e não nega fogo nunca. (Nadir, 75 anos)

Percebe-se, nas próprias citações, o lugar afetivo-social de onde falam os representantes de cada gênero, correspondendo às expectativas sociais que sempre houve em relação a eles ou nunca houve em relação a elas. Os homens falam da preocupação com o desempenho e a liberação do prazer. As mulheres, da cobrança de 'seriedade'; do alívio em relação ao marido autoritário, a ponto de não desejar outro e até abdicar da vida sexual; ou simplesmente do desejo de uma liberdade antes nunca experimentada; ou, enfim, da situação, extrema e sempre lamentada, de não ser desejada sequer pelos homens da sua própria geração.

No 'inverno' da vida, os homens ainda tentam (re)produzir 'tempestades' afetivosexuais; as mulheres silenciam ou 'congelam' ciosamente (ou cansadas, pelo muito que foram manipuladas em sua trajetória de vida) a sexualidade; a 'platéia' acha graça (afinal, 'quem gosta de velho é reumatismo').

Agora estamos, finalmente, no limiar de um reconhecimento social dos idosos, seja por uma imagem social de dinamismo que eles vêm construindo, seja pela sua participação em grupos (Britto da Motta, 1999a), seja pela constante visibilidade a eles dada pela imprensa. Entretanto, ainda que estejam progredindo muito, continuam pouco inseridos nos grandes circuitos das relações sociais. São ainda, como expressou 
Birman (1995:43), "sujeito em suspensão". Na expectativa de um lugar que possa ser novo e mais satisfatório e que dependerá precipuamente da consolidação de uma identidade coletiva de idosos que apenas começaram a construir, principalmente nos seus grupos, e de uma ação política que se imponha à sociedade.

\section{ConClusão}

Das reflexões e das experiências expostas, algumas conclusões podem ser destacadas. Como ponto de partida, a dificuldade de aceitação do corpo que envelhece, permanentemente retocado - às avessas - pelo tempo, enquanto a identidade do idoso, no capitalismo, se constitui com dificuldades e plena de ambigüidades: separação do corpo envelhecendo e da mente que permanece jovem; felicidade e dores imbricadas no discurso e no viver cotidiano.

Ao mesmo tempo, corpos que há muito já 'não são bons' para o trabalho, voltando agora a ser requisitados pelo mercado, pelo 'mérito' da falta de exigência da carteira assinada, do passe livre em transportes, da fila especial e mais rápida nos bancos e pelas virtudes, até então não capitalistas, da paciência, da experiência e da criatividade cotidianas. E com isso sentindo-se mais saudáveis: "já não durmo de dia"; "a coluna parou de doer".

O momento é de acelerada mudança, permanente transição. Se o corpo, imagem física do idoso, vai passando de descuidado a pretensamente e - não raro desajeitadamente disciplinado (Foucault, 1997), a imagem social vai melhorando em ritmo mais seguro. Na realidade, ainda coexistem as duas imagens: a tradicional, 'naturalizada', do velho inativo, respeitável, mas 'inútil'; e a nova imagem, mais dinâmica e participante, embora apenas em determinadas situações sociais. Esta ironicamente propiciada, grosso modo, pela sociedade de consumo, ávida pelas pensões e pelos 'benefícios' dos aposentados. Apenas em contraponto - e não é tão pouco assim -, a reação ou construção política do movimento dos aposentados e a pedagogia inesperada (Britto da Motta, 1999a) da sociabilidade e construção de uma identidade coletiva de idosos, nos seus grupos.

\section{Notas}

1 Meu principal problema na pesquisa com os de idade mais avançada é, justamente, de ordem informativo-bibliográfica.

2 No original: "It is as though, walking down Shaftesbury Avenue as a fairly young man, I was suddenly kidnapped, rushed into a theatre and made to don the grey hair, the wrinkles and the other attributes of age, then wheeled on stage. Behind the appearance of age I am the same person, with the same thoughts, as when I was younger." 


\section{Referências Bibliográficas}

ARIÈS, P. História Social da Criança e da Família. Rio de Janeiro: Zahar, 1978.

ARIÈS, P. Une histoire de la vieillesse? Communications, 37:47-54, 1993.

BIRMAN, J. Futuro de todos nós: temporalidade, memória e terceira idade na psicanálise. In: VERAS, R. (Org.). Terceira Idade. Rio de Janeiro: Relume-Dumará, Unati/Uerj, 1995.

BEAUVOIR, S. O Segundo Sexo. Rio de Janeiro: Nova Fronteira, 1980.

BOLTANSKI, L. As Classes Sociais e o Corpo. Rio de Janeiro: Graal, 1979.

BOSI, E. Memória e Sociedade: lembranças de velhos. São Paulo: T. A. de Queiroz, Edusp, 1987.

BOURDIEU, P. A juventude é apenas uma palavra. In: BOURDIEU, P. Questões de Sociologia. Rio de Janeiro: Marco Zero, 1983.

BRITTO DA MOTTA, A. Terceira idade: gênero, classe social e moda teórica. In: COSTA, A. A. \& ALVES, I. (Orgs.) Ritos, Mitos e Fatos. Salvador: Neim/UFBa, 1997.

BRITTO DA MOTTA, A. Chegando pra idade. [Niterói: REUNIÃO DA ABA, 19, 1994]. In: LINS DE BARROS, M. M. (Org.) Velhice ou Terceira Idade? Estudos antropológicos sobre identidade, memória e política. Rio de Janeiro: Fundação Getúlio Vargas, 1998.

BRITTO DA MOTTA, A. Não Tá Morto Quem Peleia: a pedagogia inesperada nos grupos de idosos, 1999a. Tese de Doutorado, Salvador: Faculdade de Educação, Universidade Federal da Bahia.

BRITTO DA MOTTA, A. Sociabilidades de Gênero e Geração: idosos no limiar do século XXI. Porto Alegre: CONGRESSO BRASILEIRO DE SOCIOLOGIA, 10, $1999 \mathrm{~b}$.

COLASANTI, M. Rota de Colisão. Rio de Janeiro: Rocco, 1994.

DEBERT, G. G. Envelhecimento e representação da velhice. Ciência Hoje, 8:60-68, 1988.

DEBERT, G. G. Gênero e envelhecimento. Estudos Feministas, 2(3):33-51, 1994.

FEATHERSTONE, M. \& HEPWORTH, M. The mask of ageing and the postmodern life course. In: FEATHERSTONE, M.; HEPWORTH, M. \& TURNER, B. S. (Eds.). The Body: social process and cultural theory. Londres: Sage Publications, 1991.

FEATHERSTONE, M. O curso da vida: corpo, cultura e imagens do processo de envelhecimento. In: DEBERT, G. (Org.) Antropologia e Velhice. Campinas: IFCH/Unicamp, 1994. (Textos didáticos, 13).

FERREIRA, M. L. M. O retrato de si. In: LEAL, O. F. (Org.) Corpo e Significado. Porto Alegre: Editora da Universidade, 1995.

FOUCAULT, M. Vigiar e Punir. Petrópolis: Vozes, 1977.

GARCÍA MÁRQUEZ, G. O Amor nos Tempos do Cólera. Rio de Janeiro: Nova Fronteira, 1987.

GUERRERO, P. A Universidade para a $3^{\underline{a}}$ Idade da PUC de Campinas e a Experiência do Envelhecimento, 1994. Trabalho final de Graduação, Campinas: Unicamp. 
GOMES, M. Q. de C. Esquecimento e Envelhecimento: representações e cotidiano, 1997. PósGraduação em Gerontologia Social, Salvador: Centro de Estudos e Pós-Graduação Olga Mettig.

LENOIR, R. L'invention du troisième âge: constitution du champ des agents de gestion de la vieillesse. Actes de la Recherche en Sciences Sociales, 1:26-27, mar./abr.1979.

LOBATO, L. \& MENDES, A. C. A Dança como Fator de Reintegração do Idoso no Universo Social Ativo. Salvador: Escola de Dança da UFBa, 1993. (Mimeo.)

MAUSS, M. Sociologia e Antropologia. São Paulo: Edusp, 1974. (As técnicas corporais, II)

PEIXOTO, C. De volta às aulas ou como ser estudante aos 60 anos. In: VERAS, R. (Org.) Terceira Idade: desafios para o terceiro milênio. Rio de Janeiro: Relume-Dumará, Unati, 1997.

PEREIRA, I. A. et al. Idosos em Movimento: a conquista de um direito, 1992. Trabalho final de Graduação. Salvador: Departamento de Sociologia, Faculdade de Filosofia e Ciências Humanas, UFBa.

PUCCAMP. A Universidade para a Terceira Idade na PUCCamp: proposta e ação inicial. Campinas, 1991.

RIBEIRO JÚNIOR, R. L. Os Idosos da Praça. Relatório preliminar de pesquisa. Coord.: Alda Britto da Motta. Salvador: Neim/UFBa, jan.1995.

SIMÕES, J. A. A Maior Categoria do País: notas sobre a constituição do aposentado como ator político. Caxambu: ENCONTRO ANUAL DA ANPOCS, 18, 1994.

VERAS, R. \& CAMARGO JÚNIOR, K. R. Idosos e universidade: parceria para a qualidade de vida. In: VERAS, R. Terceira Idade. Rio de Janeiro: Relume-Dumará, Unati/Uerj, 1994. 


\section{3 \\ 0 Idoso em Processo de Demência: o impacto na família}

Célia Pereira Caldas

Embora a grande maioria das pessoas envelheça sem grande comprometimento cognitivo, é importante considerar que, no âmbito da assistência à saúde do idoso, uma especial atenção deve ser dada às pessoas que vivenciam um processo demencial. $\mathrm{Na}$ verdade, essa assistência é principalmente prestada pela família, centrada na figura do cuidador principal.

O cuidador principal é aquele que tem a total ou a maior responsabilidade pelos cuidados prestados ao idoso dependente, no domicílio. Os cuidadores secundários são os familiares, voluntários e profissionais, que realizam atividades complementares. Usa-se a denominação 'cuidador formal' (principal ou secundário) para o profissional contratado (auxiliar de enfermagem, acompanhante, empregada doméstica etc.) e 'cuidador informal' para os familiares, amigos e voluntários da comunidade.

Em relação ao cotidiano dos cuidadores, Witmer (1990) afirma que, à medida que a pessoa vai desenvolvendo um processo demencial, há uma mudança de papéis dos membros da família. Se o doente é um dos pais, os filhos adultos assumem a função de decidir e assumir as responsabilidades dos pais. O filho adulto torna-se cuidador e ficará sobrecarregado com essa função, que se soma às atribuições familiares e a seu emprego.

Freqüentemente os familiares vêem-se limitados, e os sentimentos de desespero, raiva e frustração alternam-se com os de culpa por 'não estar fazendo o bastante' por um parente amado. A rotina doméstica altera-se completamente. Geralmente há uma perda da atividade social da família. Muitos amigos não entendem as mudanças ocorridas com a pessoa que torna-se demente e se afastam. O aumento da despesa também é fator preocupante para a família.

Mendes (1995) aponta que, geralmente, as decisões de assumir os cuidados são mais ou menos conscientes, e os estudos revelam que, embora a designação do cuidador seja informal e decorrente de uma dinâmica, o processo parece obedecer a certas regras, refletidas em quatro fatores: parentesco - com frequiência maior para os cônjuges, antecedendo sempre a presença de algum filho; gênero - com predominância para a mulher; proximidade física - considerando quem vive com a pessoa que requer os cuidados; proximidade afetiva - destacando a relação conjugal e a relação entre pais e filhos. 
Os cuidadores principais são os sujeitos desta investigação. Em direção a eles, busquei abrir-me e realizar este esforço de analisar as suas necessidades como pessoas que cuidam de outra pessoa que é idosa e vivencia um processo demencial.

A dinâmica da atenção ao idoso que vive um processo de demência tem toda uma estrutura específica que difere da assistência ao idoso sem comprometimento cognitivo. Vivenciar um processo que apresenta um curso de deterioração progressiva pode ter efeitos devastadores nas pessoas afetadas e em seus familiares.

O idoso e sua família necessitam de uma rede de apoio ampla, que inclui desde o acompanhamento ambulatorial da pessoa doente até o suporte estratégico, emocional e institucional para quem cuida.

A demência tem assumido maior importância como problema de saúde pública devido ao aumento da população envelhecida em todo o mundo, particularmente na faixa etária acima dos 80 anos. Por ser um processo geralmente irreversível e para o qual não há perspectiva de intervenção medicamentosa nem indicação de institucionalização, é fundamental que a família e a comunidade aprendam a conviver e lidar com uma realidade cada vez mais comum: a existência de pessoas em processo demencial.

Hoje, a demência é reconhecida como uma síndrome caracterizada por deterioração intelectual que ocorre em adultos e é tão severa que interfere no desempenho social da pessoa. Ocorrem alterações cognitivas que incluem distúrbios de memória, linguagem, percepção, práxis, habilidade de desempenhar o autocuidado, capacidade de solucionar problemas da vida cotidiana, pensamento abstrato e capacidade de fazer julgamentos.

Este estudo trata, portanto, de pessoas em uma situação muito particular. Seu objeto são as experiências e vivências dos cuidadores. Seu objetivo é compreender o significado de cuidar nessa situação, com toda a sua carga emocional, física, material e social.

A questão norteadora do estudo é: qual o significado de cuidar de uma pessoa idosa com a qual se tem vínculos familiares? Essa questão emergiu da minha prática de atendimento ambulatorial aos idosos em processo demencial. Esta abordagem inclui uma avaliação da estrutura de suporte e cuidado, avaliações periódicas da evolução da doença, da qualidade da relação cuidador-idoso e do cuidado prestado, além de realização de trabalhos com grupos que operam com cuidadores.

Tornou-se evidente, tanto na literatura especializada quanto no que eu observava em meu cotidiano profissional, que especial atenção deveria merecer o cuidador quando este papel era exercido por um familiar. E nem sempre a intervenção profissional obtinha sucesso no suporte à assistência ao idoso.

Esse familiar é o principal responsável pelos cuidados e assume a maior parte da carga física e emocional. Por ter uma relação com o idoso anterior ao processo demencial, esse cuidador demonstra de diversas formas a dificuldade de aceitar a transformação daquele ente querido que progressivamente vai assumindo um outro modo de ser, embora o mesmo corpo tão conhecido permaneça.

Portanto, minha própria trajetória profissional levou-me ao momento de buscar ampliar a compreensão do significado desse cuidar. Este trabalho teve a motivação de fundamentar minha prática por meio da compreensão, aprofundando o meu nível de reflexão. 


\section{Caracterização do Grupo dos Depoentes}

A investigação foi desenvolvida com cuidadores acompanhados na unidade ambulatorial da Universidade Aberta da Terceira Idade da Universidade do Estado do Rio de Janeiro (Unati/Uerj) - programa de extensão que mantém atividades socioeducativas e culturais para idosos, além de dois ambulatórios de atenção à saúde do idoso.

$\mathrm{O}$ estudo baseia-se nos depoimentos de 18 pessoas que cuidam de familiares idosos em processo demencial. Foram realizadas entrevistas individuais no período de abril a julho de 1998. O interesse não foi apenas saber o que pensam ou a sua opinião, mas também o que sentem e como experienciam/vivenciam a situação de cuidadores.

Os depoimentos foram colhidos por meio de entrevista guiada pela seguinte pergunta: - como você se sente cuidando do Sr. ou da Sra. ...... nesse processo de demência?

O grupo de depoentes é composto por 17 mulheres e um homem. Este dado reflete o predomínio de mulheres assumindo a tarefa de cuidar dos familiares idosos apontado pela literatura. Na ocasião em que os dados foram colhidos, essas eram as famílias acompanhadas pelo serviço.

Todas as pessoas entrevistadas cuidam de familiares que se encontravam em um estágio intermediário, porém, com um tempo de cinco a dez anos de evolução, o que significa que todos os pacientes já estavam no final desta fase, começando a apresentar alguns sinais de deterioração na área de linguagem e/ou motora que apontavam para o início da fase avançada da doença.

Apenas três famílias têm uma renda familiar entre oito e dez salários mínimos; as demais situam-se numa faixa de dois a cinco salários mínimos. Nenhuma família tinha disponibilidade financeira para arcar com os custos de contratar uma pessoa (um cuidador formal) para auxiliar nos cuidados.

Entre os depoentes, havia 15 donas-de-casa, duas mulheres que ainda trabalhavam fora, ambas auxiliadas pelos filhos para cuidar de seus familiares doentes quando se ausentavam, e o homem do grupo era aposentado.

A idade dos pacientes variava entre 67 e 89 anos, sendo $50 \%$ entre 67 e 79 e $50 \%$ entre 80 e 89 anos. A idade dos depoentes variava entre 36 e 78 anos: havia nove pessoas entre 36 e 50 anos, quatro entre 51 e 69 anos e cinco entre 60 e 80 anos.

Quanto à relação de parentesco entre os depoentes e os doentes, predominam filhas (e um filho) cuidando de mães - oito pessoas. Havia também cinco esposas cuidando de seus maridos e quatro mulheres cuidando respectivamente de sogra, sogro, irmã e avó.

\section{Cuidado Familiar e a Atenção ao ldoso: aspectos socials, CULTURAIS E POLÍTICOS}

É característica de todos os países do mundo que o cuidado dos idosos seja feito por um sistema de suporte informal. Esse sistema inclui família, amigos, vizinhos e 
membros da comunidade. Geralmente, é uma atividade prestada voluntariamente, sem remuneração. A família predomina como alternativa no sistema de suporte informal.

De acordo com Kosberg (1992), existem muitas explicações para o cuidado familiar dos idosos. Certamente a influência da tradição histórica é importante. Se na sociedade a responsabilidade tem sido da família, então o idoso já traz esta expectativa e a família não a questiona. Nesse contexto tradicional, o cuidado familiar faz parte da cultura. Quando não cumpre essa função adequadamente, a família sofre sanções sociais, pois é considerada negligente e/ou irresponsável.

Adicionalmente aos imperativos culturais, existem os preceitos religiosos. Muitas religiões no mundo, se não todas, sustentam a noção da responsabilidade da família pelos idosos (assim como por outros membros dependentes). As religiões orientais, por exemplo, enfatizam a norma da piedade filial, as religiões judaico-cristãs instruem seus seguidores a honrar seus pais e suas mães.

As mulheres da família têm sido a maioria entre os cuidadores de idosos. Isso vem sendo constatado na maioria dos países. Parte da explicação desse fato está na tradição. No passado, as mulheres permaneciam dentro da casa, o que as tornava disponíveis para essa atividade.

Embora o relacionamento entre os idosos e suas famílias varie de uma cultura para outra, a maioria das sociedades valoriza a interação entre as gerações como uma das bases da construção da cultura.

Embora o cuidado familiar seja um aspecto importante da cultura, não se aplica a todos os idosos. Existem idosos que não têm família. Esses idosos podem não ter se casado, ser viúvos e/ou não ter filhos. Os filhos de alguns idosos podem ter morrido ou mudado para longe de seus pais. Nos Estados Unidos, por exemplo, muitos idosos mudam-se para áreas do país com climas amenos (e com muitos serviços de apoio a eles). Em outros países, como no México e no Egito, os membros jovens da família costumam sair do país em busca de oportunidades de emprego, deixando as gerações anteriores sozinhas ou vivendo entre seus contemporâneos.

Há idosos cujas famílias são muito pobres para provê-los de cuidado adequado. Outros têm familiares que precisam trabalhar e não podem fazê-lo em horário parcial ou deixar o mercado de trabalho para cuidar deles. Além disso, há os idosos que perderam o contato com as famílias ao longo dos anos.

Embora geralmente as famílias cuidem de seus parentes idosos, situações de convulsão social, fome, doença disseminada, conflitos internos e guerras, entre outros eventos catastróficos, podem alterar os sistemas tradicionais de cuidado.

Outra razão por que a família não pode ser vista como a única estrutura para o cuidado das pessoas idosas é a qualidade do relacionamento com seus parentes. Muitos argumentos em favor da obrigação que os filhos têm de cuidar dos pais são baseados na crença de que existe um bom relacionamento entre as gerações. É evidente que tal suposição pode ser facilmente desafiada pela existência de conflitos permanentes, por situações de abandono do lar por um dos cônjuges e desarmonia familiar resultante de incompatibilidade de personalidades, de valores e de estilos de vida entre os jovens e os mais velhos. 
Portanto, embora tradicionalmente os idosos tragam a expectativa de serem cuidados por seus filhos, e os filhos adultos não tenham dúvidas sobre a sua responsabilidade pelos pais, estas expectativas e desejos vêm mudando. Certamente existem evidências da quebra de responsabilidades tradicionais como conseqüência da urbanização. A maior influência da urbanização certamente é a transformação das estruturas familiares de famílias extensas em famílias nucleares, o que diminui a disponibilidade de parentes para cuidar dos mais velhos.

Outra questão a se destacar é que muitas pessoas não querem ser dependentes de seus filhos adultos ou de outros membros da família. Esse fato muitas vezes gera a demora da própria família em constatar que precisa assumir a assistência ao seu parente idoso.

Um cuidado que se apresenta de forma inadequada, ineficiente ou mesmo inexistente é observado em situações nas quais os membros da família não estão dispostos, estão despreparados ou sobrecarregados por essa responsabilidade. Em tal contexto, existe a possibilidade concreta de serem perpetrados abusos e maus-tratos. Portanto, é necessário lembrar que, embora a legislação e as políticas públicas afirmem e a própria sociedade considere que os idosos devem ser assistidos pela família (por razões morais, econômicas ou éticas), não se pode ter como garantido que a família prestará um cuidado humanizado.

Os padrões tradicionais de funções familiares parecem estar se desmontando diante das transformações sociais, econômicas e demográficas. Como consequiência, mudam os valores culturais em relação aos idosos em geral e ao cuidado familiar do idoso, em particular.

Para acompanhar o fluxo de tais mudanças, são imprescindíveis programas e serviços para os idosos. Tais recursos são urgentemente necessários, pois muitos idosos isolados, dependentes e abandonados necessitam de alternativas à assistência familiar de que não dispõem. Embora se constate, em muitos países, uma apreensão quanto à possibilidade de, ao oferecerem alternativas públicas, contribuírem para legitimar e encorajar o abandono das responsabilidades pela família, é preciso considerar que uma forma de o Estado garantir aos cidadãos de qualquer idade os seus direitos sociais é reconhecer a necessidade e implantar estruturas de apoio aos idosos e suas famílias por meio de uma parceria entre governo, comunidade local, vizinhança, ONGs, setor privado e organizações religiosas.

Beauvoir (1990) afirma que o status da velhice é imposto ao homem pela sociedade à qual pertence. A sociedade lhe destina um lugar e um papel, e o indivíduo que envelhece é condicionado pela atitude prática e ideológica da sociedade em relação a ele. A autora destaca também que a velhice difere de acordo com o contexto social em que viveu e vive o indivíduo. Assim, não existe uma velhice, mas há velhices: masculina e feminina; uma dos ricos, outra dos pobres; uma do intelectual, outra do funcionário burocrático, ou do trabalhador braçal.

Destacando o Brasil como uma sociedade heterogênea, Veras (1994) acrescenta que, apesar de o país ter uma das dez maiores economias do mundo, a distribuição da riqueza se caracteriza pela iniqüidade e pela concentração de recursos nas mãos de relativamente poucos. Isso se reflete nas condições de vida dos cidadãos idosos, gerando um grande contingente de pessoas cuja fragilização econômica termina por 
intensificar a fragilização da saúde, considerando que as condições de vida determinam a capacidade de se manter uma reserva fisiológica suficiente para garantir a homeostase na velhice.

Portanto, tratar um país como o Brasil pela média - isto é, considerando uniforme sua estrutura social, econômica e demográfica - é um erro metodológico e de graves conseqüências para o planejamento, por distorcer a realidade, impedindo sua correta apreensão. Para planejar e/ou legislar sobre a questão da assistência ao idoso, é importante considerar os diferentes contextos sociais, econômicos e culturais nos quais estão inseridos os cidadãos mais velhos de nossa sociedade. Certamente, as ciências sociais, particularmente a antropologia, têm muito a contribuir nesse esforço.

O governo brasileiro instituiu a Política Nacional do Idoso, regulamentada pelo Decreto n⿳-1.948, de 13 de julho de 1996 (Brasil, 1997, 1999). Uma das diretrizes dessa política recomenda que o atendimento ao idoso deve ser feito por intermédio de suas próprias famílias, em detrimento do atendimento asilar. Para assumir tal responsabilidade, a família necessita de uma rede social e de saúde que constitua um suporte para lidar com seu familiar idoso à medida que este se torne mais dependente. Entretanto, essa rede de suporte não existe em nosso país.

Um dos aspectos importantes dessa rede é a formação de recursos humanos preparados para lidar com a família do idoso, particularmente do idoso mais dependente, como aquele que vivencia o processo de demência.

A recente Política Nacional de Saúde do Idoso (1999) reconhece a importância da parceria entre os profissionais da saúde e as pessoas que cuidam dos idosos, apontando que esta deverá possibilitar a sistematização das tarefas a serem realizadas no próprio domicílio, privilegiando-se aquelas relacionadas à promoção da saúde, à prevenção de incapacidades e à manutenção da capacidade funcional do idoso dependente e do seu cuidador, evitando-se assim, na medida do possível, hospitalizações, internações em asilos e outras formas de segregação e isolamento.

A demência precisa ser reconhecida como uma importante questão da saúde pública. Seu impacto sobre a família e a sociedade não pode ser subestimado. Os distúrbios demenciais são a principal causa de incapacidade e de dependência na velhice.

Em estudo realizado em três bairros do Rio de Janeiro (Copacabana, Méier e Santa Cruz), Veras (1994) indicou, após análise dos resultados, que há muitos fatores de risco associados à deficiência cognitiva: a natureza marcadamente dependente da idade que caracteriza a demência, a predominância de mulheres (como resultado do fator idade, pois as mulheres têm maior expectativa de vida), a acentuada importância dos fatores socioeconômicos e a associação com a incapacidade de desempenhar as atividades cotidianas. Esses fatores, associados, deveriam ser suficientes para deflagrar um crescimento da preocupação da saúde pública com o problema.

$\mathrm{O}$ aumento do número de casos de demência relacionado diretamente ao aumento da expectativa de vida na população já torna a questão um problema da saúde pública. Além disso, não há justificativa, a princípio, para defender a institucionalização de idosos que vivenciam um processo demencial. E mesmo que a institucionalização fosse uma prática aceitável na assistência ao idoso demente, há o fato de que a internação institucional não garante atendimento correspondente à satisfação de suas necessida- 
des (Duarte, 1991). É necessário, portanto, que a sociedade esteja preparada e que existam meios para lidar com os seus cidadãos idosos que desenvolvem um processo de demência na comunidade.

Ao analisar as possibilidades de suporte social e de saúde para a família de um idoso que vivencia um processo de demência, constata-se logo que existem poucas instituições voltadas para este campo. Dentre as públicas, destacam-se as universidades. É importante citar a existência de grupos voluntários nos quais os próprios cuidadores promovem encontros com o objetivo de ajuda mútua.

\section{Processo Demencial}

De acordo com Barclay (1993), demência é uma síndrome clínica de deterioração das funções corticais superiores, incluindo memória, pensamento, orientação, compreensão, cálculo, capacidade de aprendizagem, linguagem e julgamento ou discernimento. Ela ocorre com manutenção da consciência e com severidade suficiente para interferir nas funções sociais e ocupacionais do indivíduo. O termo 'deterioração' implica a redução de habilidades previamente conhecidas e estabelecidas.

A demência tem causas primárias e secundárias. Cassel (1990) cita como causas primárias as doenças de Alzheimer, Pick, Huntington, Parkinson, paralisia supranuclear progressiva, degeneração espino-cerebelar, calcificação idiopática dos gânglios da base, degeneração estriato-nigral, xantomatose cérebro-espinhosa, leucodistrofia metacromática.

As causas secundárias são os acidentes vasculares cerebrais; traumatismos; condições intracranianas; distúrbios endócrinos e metabólicos; estados de deficiência de vitamina $B_{12}$, vitamina $B_{6}$ e ácido fólico; infecções; intoxicações e desordens psiquiátricas como esquizofrenia, mania e alcoolismo.

Caso o processo demencial seja secundário a alguma outra doença, seguem-se o tratamento específico da causa e o acompanhamento subseqüente, com avaliação da melhora e da evolução. Quando a causa não é tratável, investe-se no acompanhamento das doenças concomitantes, como hipertensão arterial, diabetes, disfunção tireoidiana e outras, na tentativa de retardar o processo.

Dentre as causas citadas, as mais freqüentes são a doença de Alzheimer (causa primária) e a vascular (causa secundária).

Estima-se que a doença de Alzheimer afeta de 3\% a 5\% das pessoas acima de 65 anos, chegando a atingir $40 \%$ após os 85 anos. Seu início se dá normalmente após os 50 anos, com predominância nas mulheres. Encontramos na literatura diversas classificações de estágios de evolução da patologia, variando entre três e sete fases. Para o que nos interessa, que é o cuidado, a divisão em três fases é suficientemente didática para a compreensão do problema:

- Estágio inicial: estão presentes anomia, pobreza de vocabulário, dificuldade de aprendizado e memória, dificuldade construcional, julgamento ou discernimento empobrecido. As funções motoras e sensoriais continuam normais. 
- Estágio intermediário: contínua redução de todas as funções intelectuais, afasia com erros parafásicos (substituição incorreta ou sem sentido), compreensão pobre, memória recente e remota bastante reduzida; capacidade prejudicada de cálculo e cópia. Os pacientes são usualmente indiferentes à sua condição. Estão presentes sintomas depressivos. As funções motora e sensorial se mantêm intactas. Pode haver agitação e perambulação.

- Estágio final: perda total das habilidades cognitivas. Ocorre mutismo, polilalia (repetição), ecolalia. Também a incontinência fecal e urinária está presente. Os membros tornam-se rígidos, flexionados, e pode haver mioclonia.

Barclay (1993) afirma que o comprometimento vascular-cerebral é a segunda causa mais comum de demência, ocorrendo em cerca de $30 \%$ das pessoas afetadas. Seu diagnóstico é feito com base nas características do processo demencial, que evolui em degraus, com distribuição das alterações cognitivas de forma desigual, sintomas e sinais neurológicos focais e evidências de doença neurológica pelo exame físico e anamnese.

\section{Evolução do Processo Demencial e Aspectos Importantes na Abordagem dos Profissionais da Saúde}

A fase inicial da doença pode passar de forma despercebida. Ocorrem episódios de lapsos de memória, que muitas pessoas conseguem compensar ou disfarçar por meio de estratégias como o uso de agendas ou outras formas de auxílio à memória. No entanto, progressivamente, a pessoa passa a ter dificuldades para tomar decisões e fazer planos, torna-se cada vez mais vagarosa ao falar e compreender, perde progressivamente a capacidade de manter a atenção, ter iniciativas e fazer cálculos. Então, passa a evitar interação social, pois já está com dificuldade de participar de uma conversação.

Sua memória começa a falhar, de forma que, inicialmente, as informações recentes se perdem e, progressivamente, as antigas também. Já nessa fase podem ocorrer situações de pânico, geralmente causadas pelos lapsos de memória, que deixam a pessoa subitamente desorientada. Esse estado gera grande angústia e agitação para aquele que está desenvolvendo um processo de demência e para o cuidador.

É freqüente, também nessa fase, que a pessoa fique bastante deprimida, pois como ainda está lúcida a maior parte do tempo, percebe seu estado mental se deteriorando. Essa consciência a deixa muito triste, o que se manifesta em um crescente isolamento ou recusa a participar de reuniões familiares ou sociais.

Nessa etapa da evolução da doença, os profissionais que acompanham a pessoa devem procurar envolver a família na assistência, enfatizando a necessidade de compreensão do que sente o idoso, a partir do entendimento do diagnóstico e prognóstico da patologia.

Também é necessário que nessa fase se oriente a família em relação às medidas de controle da ansiedade e da agitação. Podem-se trabalhar com o idoso técni- 
cas de orientação para a realidade, para estimulá-lo a se manter consciente de informações orientadoras corretas. A reabilitação cognitiva nesse início do processo demencial contribui para retardá-lo.

A segunda fase, ou fase intermediária, é caracterizada pelo aumento do grau de dependência, na medida em que a pessoa já necessita de supervisão e ajuda para o autocuidado. Ela passa a ter grande dificuldade para manter adequadamente a sua higiene pessoal. Como sua capacidade de julgamento ou discernimento se encontra prejudicada, a pessoa passa a apresentar comportamento inadequado e aumenta a necessidade de atenção à segurança. A casa precisa ser adaptada para isso. Surgem mudanças marcantes no comportamento, o que exige a presença de acompanhante para ir a qualquer lugar. Freqüentemente o doente inventa palavras e histórias e não reconhece pessoas. Apresenta também desorientação espaço-temporal, podendo desconhecer inclusive a sua própria casa. É freqüente acontecer, quando estão agitados e ansiosos, de pedirem para voltar para sua casa, referindo-se ao local onde passaram a infância ou a juventude.

A família costuma sofrer bastante nessa etapa não só pela necessidade de exercer vigilância permanente e controle da pessoa, mas também pela letargia e indiferença afetiva que a pessoa apresenta. Os familiares se entristecem e geralmente se sentem impotentes e já não sabem como agir. Na verdade, é necessário que os familiares aprendam uma nova forma de lidar com o seu idoso.

Embora o idoso apresente indiferença afetiva a estímulos que no passado a teriam motivado, mantém uma afetividade inalterada, ou seja, ela necessita e aceita com satisfação carinhos, afagos, abraços e palavras carinhosas de qualquer pessoa, mesmo que não a esteja reconhecendo. Por isso, quem desempenha o papel de cuidador principal é a 'âncora' do idoso. Sua segurança e tranqüilidade dependem da percepção que tem da segurança e da tranqüilidade que o cuidador principal lhe transmite.

Os profissionais responsáveis pelo acompanhamento deverão enfatizar nessa fase a prevenção de acidentes, as orientações sobre alimentação e medicação, o estabelecimento de rotinas para as eliminações fisiológicas e o reconhecimento de outros códigos de comunicação, pois o idoso já não consegue expressar verbalmente o que está querendo ou sentindo. É preciso desenvolver a habilidade de se comunicar com ele utilizando outros códigos.

Muitos idosos, principalmente aqueles que foram bem ativos no passado, poderão sentir necessidade de caminhar, o que chamamos de 'perambulação'. Nesse caso, não se pode impedi-los, apenas verificar que não o estejam fazendo compulsivamente além das suas forças e que haja proteção ambiental. Se não houver condições de o idoso caminhar dentro de casa e precisar ir para a rua, deve estar acompanhado e usar alguma forma de identificação.

A fase final é marcada pela dependência total da pessoa. Há necessidade de cuidados integrais no leito permanente, devido à perda da atividade psicomotora. Nesse momento, os profissionais da equipe de enfermagem deverão orientar os cuidadores para prestarem os cuidados básicos, priorizando o conforto e o afeto. É importante manter o suporte familiar. Toda a equipe profissional deve estar apoiando a família que vivencia as perdas progressivas e a iminência da morte. 


\section{RESULTADOS: A ANÁLISE DAS UNIDADES DE SIGNIFICADO}

Com a análise desenvolvida, buscou-se produzir um saber sobre o cotidiano dos cuidadores com base em suas próprias falas. As unidades de significado foram analisadas/tratadas de modo a garantir que esse ente, sujeito do estudo, pudesse "mostrar-se em si mesmo e por si mesmo, isto é, mostrar o ser-aí em sua cotidianidade mediana, tal como ela é antes de tudo e na maioria das vezes" (Heidegger, 1995:44).

Os resultados do estudo evidenciam, como traços gerais, que o cuidador apresenta-se como pessoa que:

- vivencia grande sofrimento por conviver com a progressão do processo demencial de seu familiar;

- consegue desenvolver o cuidar enfrentando grandes dificuldades, porque não vê outra saída;

- apresenta um grande cansaço ao cuidar do familiar idoso de quem se ocupa intensamente;

- precisa ter muita paciência para lidar e cuidar de seu familiar idoso que está desenvolvendo um processo de demência;

- está tensa, cansada e limitada no seu lazer porque assume a obrigação de cuidar de seu familiar, que apresenta grande dependência;

- reconhece a necessidade de ser cuidado também, porque enfrenta dificuldades pela intensidade da ocupação de seu tempo e de suas emoções.

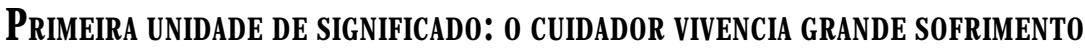 POR CONVIVER COM A PROGRESSÃO DO PROCESSO DEMENCIAL DE SEU FAMILIAR}

Os cuidadores vivenciam o processo demencial de seu familiar idoso como uma despedida gradual da vida para a morte. Têm consciência disso e sofrem. É um sofrimento gerado pela lembrança e pela constatação de que a pessoa está se tornando cada vez mais dependente. A personalidade do familiar no passado é recordada a todo momento e eles sentem saudades do tempo em que a pessoa era ativa e independente.

Eu me sinto sem Deus, numa terra sem lei, injustiçada. É sério! Porque eu acho que não tem a quem atribuir certo destino, ou se for uma má alimentação, ou um... azar, mas acho ela não merecia um fim desses. É isso que dói. Não é autopiedade minha, não, é a dor do porquê esse destino para ela. Eu estou muito me questionando. Sei lá, acho que a vida foi muito injusta com ela. Ela não merecia isso, não. Que o problema não é... eu estou, aos poucos, tomando consciência de como cuidar etc. e tal, mas a minha maior dificuldade... Por que com ela, cara?

O cuidador vai se despedindo daquilo que o seu familiar foi e sempre sentirá saudades da antiga maneira de ser, mas irá aos poucos aprendendo a reconhecer e a 
amar essa 'nova pessoa', a cada dia mais dependente e indefesa. O cuidador tende a se sentir responsável por sua vida, por seu bem-estar. É uma responsabilidade nascida do sofrimento e da dor.

O cuidador também tem de mudar completamente a tradição relacional própria da dinâmica e da estrutura familiar; os papéis são trocados. Com o processo demencial, aquele que sempre cuidou passa agora a ser o centro das atenções. Muitas vezes essa pessoa assumia no passado o papel de provedor ou responsável pela família. Os cuidadores apontam claramente como é doloroso vivenciar essa mudança:

Agora eu me sinto recompensada, porque ela fez tanto isso por mim. Eu fui criada com ela. Tenho mãe, tenho pai, mas eu e meu irmão fomos criados com ela. Tudo que estamos fazendo por ela, hoje, ela fez pela gente ontem: ela deu banho, ela deu vacina, levou para o médico, né? Hoje, a gente faz a mesma coisa por ela e com bastante paciência; antes eu não tinha muita, não, mas agora eu tenho. Graças a Deus, pedi tanto a Deus que me desse paciência... Não quero ficar assim que nem ela, mas também não quero maltratar.

A mudança e a aceitação da situação são um processo desencadeado a partir do momento em que o cuidador toma consciência do diagnóstico e a doença vai se configurando mais real a cada dia, com o avançar dos sintomas. Mesmo que já venha percebendo que o seu familiar está ficando diferente, está perdendo a memória, agindo de forma inusitada, o momento em que o cuidador ouve do profissional que o seu familiar tem uma síndrome demencial é um instante único. É um choque. Ele é forçado a encarar a realidade dolorosa que já intuía:

Ele era um professor muito respeitado. Tinha sido diretor da escola e passou a ser relapso com os seus compromissos. Eu achava que era malandragem, mas como eu era professora também, passei a ajudá-lo e aí percebi que algo errado estava acontecendo com ele. Levei a um médico especialista, que diagnosticou doença de Alzheimer. Eu não levei a sério no início, até o dia em que ele foi à padaria sozinho, se perdeu e precisou da ajuda de um porteiro de um prédio vizinho para retornar para casa.

Eu cuido de uma pessoa que tem 84 anos hoje. Há cinco ou seis anos, essa pessoa começou com uma demência. Para mim foi muito angustiante, muito sofrido, muito triste, porque eu tinha um filho de seis anos na época. Aí os anos foram passando e o tratamento dos médicos, as pessoas que foram responsáveis pelo tratamento, me deram força bastante, me ajudaram, e eu fui amadurecendo...

O sofrimento irá acompanhar toda a trajetória de cuidado até a morte do familiar, porém, a forma de conviver com a situação muda de tom com a experiência. No início, é a angústia pelo diagnóstico e pela irreversibilidade:

Ela é muito agitada, sempre foi por natureza. E agora, por causa da doença, piorou. Eu me sinto angustiada. Eu acho que o que eu sinto é o que o meu marido sente: é aquela angústia, porque nós queremos ajudá-la a se recuperar e essa doença parece que não tem recuperação, né? (...) É justamente isso que eu estou dizendo. É o idoso que tem essa doença, então vai tendo uma regressão até chegar à posição fetal. Então eu acho angustiante. A gente fica triste... 
Depois do impacto e da aceitação do diagnóstico, vem a dor por assistir à perda das habilidades cognitivas, principalmente a perda da capacidade de julgamento ou discernimento. Eles relatam que é muito triste ver seu familiar tendo um comportamento inadequado e fazendo coisas que jamais faria se não estivesse desenvolvendo um processo de demência:

Está meio difícil, mas tem que saber entrar no meio deles, não levar tão a sério, entender aquela doença. Uma hora ele está como uma criança, uma hora ele fala coisas que não têm nexo. A gente tem que se adaptar àquele mundo; é meio difícil.

Ao chegar à fase de perda da linguagem, ele enfrenta o desafio de conseguir se comunicar com seu familiar, sente falta basicamente de poder conversar. Mas a essa altura, o cuidador possivelmente já desenvolveu outros códigos não verbais de comunicação:

Eu gostaria de ter uma certeza do que ela sente. Ela sente muitas dores, que eu sei, e ela não pode passar isso para mim, para dizer o que ela teme, o que ela sente, porque eu conheço, no semblante dela eu sei quando ela está com dor.

É interessante observar que os cuidadores relatam, mesmo sabendo que o idoso talvez não esteja entendendo aquilo que dizem, que continuam falando com o idoso. Sentem a necessidade do diálogo com a pessoa que ali está, mesmo que a possibilidade do diálogo por meio da linguagem falada não exista mais:

Olha, eu acho que, devido ao tempo, eu já encaro assim como se ela fosse uma pessoa normal. Às vezes eu falo para ela, e a minha filha diz: 'Mãe você está fazendo pergunta para a vovó, conversando com ela?! A senhora não está vendo que a vovó não está escutando nada?' Mas tem hora que ela está ouvindo, sim, não todos os dias, mas tem dia que você levanta, você olha para ela, ela te olha nos olhos, assim, não fala. Ela olha assim às vezes, dá um sorriso, muito assim sem graça, mas dá. Então, a gente sabe que ela não fala, não se expressa, não emite som nenhum, mas que lá no seu eu, né, ela deve refletir alguma coisa, só não pode, claro, falar.

$\mathrm{Na}$ fase de perda da atividade motora, quando o seu familiar fica restrito ao leito, totalmente dependente de cuidados integrais, o sofrimento do cuidador está mais ligado à iminência da morte e por vê-lo tão inerte, tão imóvel no leito:

Hoje eu já queria, eu já quero, eu já fico pensando, se não seria melhor essa pessoa sair desse sofrimento. Porque é muito sofrimento, cuidar de uma pessoa assim... ver a pessoa se acabar aos poucos. Já está se transformando até numa angústia eu ver aquela pessoa se acabar, se acabando aos poucos e eu sem poder fazer nada e querendo aliviar a dor, o mal-estar que acomete essa pessoa.

Apesar da consciência de que a morte representará o descanso para ambos, o cuidador sofre porque continua sentindo falta daquilo que o idoso fazia e foi. A morte é então o afastamento total, determinando que aquilo que o seu familiar foi acabou. Ele segue não aceitando a perda da antiga maneira de ser de seu ente querido, porém essa nova maneira de ser é a única ponte com o passado. E é exatamente esse vínculo que o cuidador tem com a pessoa que foi no passado que mantém o afeto e a dedicação do cuidado: 
Às vezes me perguntam: 'Por que você não interna o João?' E eu digo: ‘Eu não interno o João porque ele foi o meu companheiro e até hoje ele é meu companheiro'. Eu sento ao seu lado, eu seguro a sua mão, ele segura a minha e a gente está junto. É uma trajetória de vida que a gente tinha que passar.

Há então a possibilidade de uma transformação na qualidade desse amor. Um amor e um reconhecimento nascidos do sofrimento, pois durante aqueles anos eles viveram como uma unidade cuidador-idoso, numa relação de interdependência e amor.

\section{Segunda UnIDADE de SIGNIFICADO: CONSEgUe DESENVOLVER O CUIDAR ENFRENTANDO GRANDES DIFICULDADES, PORQUE NÃO VÊ OUTRA SAÍDA}

O cuidador espanta-se pelo que é capaz de fazer: como agüenta fazer tudo o que faz e sentir-se disposto a continuar cuidando? Compreende que é possível cuidar bem, mesmo enfrentando muitas dificuldades. Consegue vencer o desespero e a angústia, mesmo que muitas vezes pense não ser capaz:

É difícil, viu? A gente faz o que pode, né? Porque, por exemplo, às vezes a gente vê uma coisa assim: 'Ah! Eu não agüentaria fazer isso, não', mas a gente está naquele problema, o problema automaticamente a gente aprende e faz bem. A pessoa que está de fora é diferente. Até diz: 'Eu não faria isso, não!' Mas se a gente está ali naquele problema, e é uma pessoa como um pai, como uma mãe, um filho, um marido, a gente não tem como dizer que não vai fazer aquilo! Então a gente aprende e até faz bem aquilo, porque não tem jeito, né? É o que eu fazia com ele, anos assim, anos!

Ao enfrentar o processo demencial, o cuidador se esforça permanentemente para superar as dificuldades por ele desencadeadas. Ao se dar conta de que consegue cuidar, ele não deixa de sofrer, de sentir a dor. Ele passa a compreender a pessoa de que está cuidando e vivencia o processo demencial, aceitando-o e exercitando a paciência.

Eu peço muita força a Deus para que ele me dê paciência. Aí eu digo sempre, né, tem que ter paciência que ele - até as pessoas acham graça! - que ele não pediu para ficar assim, coitado... Quer dizer que eu tenho que ter paciência com ele, que assim como é ele, podia ser eu, estar no estado dele. Aí me sinto assim. Às vezes, eu fico um pouco nervosa de ver certas coisas que ele faz. É mais ou menos isso.

Ao aceitar a doença, ele percebe que a única coisa a fazer é trabalhar para tornar o futuro melhor, mais leve para ambos. Ele busca deixar de reagir contra a sua realidade e aceita o sofrimento que ela causa. Ao aceitá-lo, deixa de reagir contra e se prepara ativamente para cuidar melhor. Então, dá um passo além da aceitação e se equilibra:

Fico cansada... ao mesmo tempo que eu fico cansada, mas depois esqueço, nem estou mais cansada, não sinto mais nada, não sinto mesmo. Não sinto mais. É só naquela hora assim, mas depois fico descansada, mesmo. Tudo de novo, não tem nada, não sinto mesmo. Só aquela hora assim, depois que eu dou banho nela, cuido dela, aí depois eu fico mais descansada, parece até mentira, mas é verdade, não me sinto mais... Depois que passou... e agora? Agora eu vivo com ela, né? Agora é a mesma coisa que nada; nadinha, nadinha. 
Os depoimentos apontam que os cuidadores sentiram que não poderiam optar entre cuidar ou não cuidar. Eles simplesmente tiveram de cuidar. Não havia opção. Não há saída. Os motivos são imperativos:

Então a gente aprende e até faz bem aquilo, porque não tem jeito, né? É o que eu fazia com ele, anos assim, anos!

Aí eu parei de ficar discutindo em cima do que está acontecendo. Está acontecendo. Como está acontecendo com outras pessoas, coisas até piores. Nós temos uma trajetória. Esse negócio de livre-arbítrio... não há. Já há uma trajetória marcada que a gente tem que passar.

E assim nós vamos cuidando dele. Você vendo que ali não tem jeito, mas que é viver, no correr do dia. Eu estou me sentindo bem.

Mesmo que o cuidador demonstre que não teve escolha, alguns deles aceitam o desafio de assumir o cuidado com muita coragem e procuram estar bem. Procuram viver com maior qualidade de vida e buscam possibilidades de ser felizes cuidando do seu familiar e convivendo com ele:

Minha vida é uma luta. Muitas vezes eu desanimo. Eu tenho muita coisa pra contar... tenho muita coisa. A gente vai crescendo... todo aquele sofrimento... às vezes eu penso: isso não é justo... Agora que eu e o João... a gente podia aproveitar... sair... aí ele está assim... não é justo pra ele, nem pra mim. Mas ninguém pode julgar se seria melhor ou pior. Aí eu parei de ficar discutindo em cima do que está acontecendo. Está acontecendo. Como está acontecendo com outras pessoas, coisas até piores. Nós temos uma trajetória. Esse negócio de livre-arbítrio... não há. Já há uma trajetória marcada que a gente tem que passar. Se eu fosse contar minha vida... eu já fui muito pobre... mas me formei, fiz faculdade... Às vezes eu olho meu apartamento e não acredito que consegui chegar tão longe. Eu consegui muito... e de repente, eu fui tão longe para chegar a isso... De repente a minha vida foi pra nada. Às vezes me perguntam: 'Por que você não interna o João?' E eu digo: 'Eu não interno o João porque ele foi o meu companheiro e até hoje ele é meu companheiro'. Eu sento ao seu lado, eu seguro a sua mão, ele segura a minha e a gente está junto. É uma trajetória de vida que a gente tinha que passar.

Quando as pessoas apontam um motivo concreto para estarem cuidando do seu familiar idoso, demonstram fundamentalmente que tinham de assumir tal posição ativa e conscientemente. Isso não significa que estejam totalmente engajadas e satisfeitas por terem assumido este papel.

As razões apontadas são sempre ligadas ao significado da pessoa, o que ela fez ou representou anteriormente, num tempo que é passado. O cuidador marca o pretérito como ponto de partida para o fato de se colocar disponível e, ao estabelecer este marco, possibilita que esse exercício o transforme a cada dia.

Essa vinculação parece determinar que o cuidado se torne um ato consciente. E essa disposição determina que o idoso já não 'ocupa um lugar' na vida do cuidador; ele passa simplesmente a ser uma pessoa que vivencia um processo demencial como parte da sua própria vida: 
Eu devo essa obrigação a ela, é uma questão de gratidão, entendeu? Devo muito essa obrigação a ela. Mesmo que eu não devesse eu cuidaria dela, mas é mais um motivo por que eu dou muita atenção a ela, aos dois, mas mais a ela. Ela tratava tão bem da minha mãe, que ela colocava, eu me lembro disso, que ela colocava um babadouro igual a criança velha, para ela não se sujar na hora da refeição. Ela foi muito amorosa com a minha mãe. Então, é um dos motivos... um dos motivos, não, é o motivo principal, né? Eu tenho... Eu não posso deixar ela, de forma nenhuma, na mão, que é assim que se diz vulgarmente. Então eu tenho que cuidar dela, gratidão.

Portanto, o cuidado motivado pela vinculação anterior com o idoso é um processo que vai da mera ocupação com os afazeres do dia-a-dia, como a higiene e a alimentação, até um estado de busca de participação na existência do ente querido. Independentemente de este falar ou entender racionalmente o que está acontecendo, o cuidador se sente gratificado simplesmente por se encontrar ali naquele momento, compartilhando a vida do seu familiar.

Ele consegue estender esse sentido do cuidar e passa a compreender o mundo do seu familiar idoso que vivencia o processo demencial, amplia a sua compreensão da vida, passando a entender melhor as pessoas, e isso o transforma. O cuidador abre-se para uma nova dimensão.

Assumir-se como responsável pelo que ocorre com o idoso não é sentir-se uma vítima do destino ou da sorte. É compreender o problema. É conseguir enxergar as possibilidades de 'com-viver' com o processo demencial. É deixar a postura de espectador e se envolver no cuidado. É também se deixar cuidar, se deixar transformar pelo cuidar:

Hoje, com seis anos de luta, eu já me sinto mais tranqüila, mais madura, eu cresci muito. Eu já vejo a vida de uma maneira diferente. A vida não é como a gente quer fazer, a vida é como acontece. O dia-a-dia da gente... ninguém programa o dia de amanhã... a noite de hoje... tudo vai correndo lentamente, dependendo do que vier, das situações, dos problemas... e é assim que eu estou vendo.

\section{TERCEIRA UNIDADE DE SIGNIFICADO: AO CUIDAR DO FAMILIAR IDOSO DE QUEM SE OCUPA INTENSAMENTE, O CUIDADOR APRESENTA UM GRANDE CANSAÇO}

O cansaço que o cuidador sente é avassalador. E o pior é que não há uma perspectiva de repouso a curto prazo. Isso porque o que eles sentem não é apenas físico: é um cansaço total, existencial. O desabafo de um deles representa muito bem essa situação:

Ah! Tem dia que enche o saco, que eu estou cheia, sem memória, cuidar de casa, cuidar de filho e cuidar de sogro...

Mas eles mesmos revelam que também não sabiam que poderiam suportar tanto. Relatam que a sua capacidade de suportar o esforço vai aumentando à medida que a necessidade surge. Quando os cuidadores contam seu cotidiano em depoimentos, relatam tal carga de trabalho que chamam a atenção de quem escuta. É impressionante a freqüência com que perdem noites de sono, sendo que precisam estar bem despertos e atentos a cada dia, pois a demanda de trabalho só vai aumentando: 
Eu me sinto arrasada, né? Arrasada! Porque, às vezes, tem dia que ele não quer água. Aí eu digo para a minha filha: 'Olhe, eu vou deixar de dar água a ele', porque ele se molha todo, ele me cospe água no rosto, ele enche a boca - ôôôôôôô̂, pão!... Aí a pessoa também tem um limite. Se eu fosse novinha, tudo bem, mas também eu estou velha, né? E tem hora que é muito difícil! Uma coisa de louco! Mas é a raiva, mais a água no... (...) Você sabe que a gente pouco dorme.

O cansaço está presente todo o tempo e por toda a trajetória. À medida que a doença vai avançando, vai deixando de ser predominantemente físico. As demandas concretas de seu cotidiano não permitem um descanso absoluto. É do esforço de superar a fadiga física e existencial que se constitui a próxima unidade de significado: o exercício da paciência.

\section{QUARTA UNIDADE DE SIGNIFICADO: É NECESSÁRIO TER MUITA PACIÊNCIA PARA LIDAR E CUIDAR DE SEU FAMILIAR IDOSO QUE ESTÁ DESENVOLVENDO UM PROCESSO DE DEMÊNCIA}

Os cuidadores demonstram que a paciência precisa estar como um pano de fundo, permeando sua experiência. Caso contrário, tudo se desequilibra: o idoso, a família e a casa, a partir do descontrole do próprio cuidador:

Minha vida virou um inferno. Eu estou praticamente me separando do meu marido. Virou tudo de cabeça pra baixo... Eu estou num estresse muito grande agora.

A paciência tem relação com a capacidade de aceitar a doença como uma realidade da qual não se pode fugir. Quando o cuidador resiste a enfrentar essa realidade ou se revolta, não se abre para a possibilidade de superar o sofrimento que a doença traz a ele próprio e ao seu familiar:

Eu me sinto sem Deus, numa terra sem lei, injustiçada. É sério! Porque eu acho que não tem a quem atribuir certo destino, ou se for uma má alimentação, ou um... azar, mas acho ela não merecia um fim desses. É isso que dói. Não é autopiedade minha, não, é a dor do porquê esse destino para ela. Eu estou muito me questionando. Sei lá, acho que a vida foi muito injusta com ela. Ela não merecia isso, não. Que o problema não é... eu estou, aos poucos, tomando consciência de como cuidar etc. e tal, mas a minha maior dificuldade... Por que com ela, cara?

O exercício da paciência traz a possibilidade de não temer o processo degenerativo. Possibilita ao cuidador reconhecer e descrever todas as dificuldades vivenciadas, mas também refletir sobre elas. $\mathrm{O}$ cuidador adquire flexibilidade. Parece que o exercício da paciência vai preparando o cuidador para enfrentar todo o processo demencial, que consiste numa transformação permanente e progressiva:

A família é muito grande, mas quem pode olhar ela mesmo são poucos. Então, a gente vai fazendo. Ela tinha a mania de ficar a noite toda no banheiro lavando a mão. Esfregava tanto que até esfolava. Ela sofria muito com isso, porque a gente deixava, né? Não se dormia com ela, porque ela se levantava e ia para o banheiro. Foram anos e anos assim. Muitos anos. E a gente com a paciência até hoje. Nós temos paciência e vamos ter até o dia que Deus quiser, que Deus der saúde. 
Outro aspecto do exercício da paciência é a aceitação do ritmo do idoso. A pessoa que vivencia um processo demencial tem um ritmo totalmente próprio e sem possibilidade comparativa com os parâmetros de um indivíduo da mesma idade em plena capacidade cognitiva. Seus horários, as manifestações de suas necessidades e vontades são totalmente atípicos; muitas vezes, ilógicos. Tudo exige paciência para aceitar e compreender esse comportamento.

Quando não se tem paciência, força-se o idoso (que já não pode entender racionalmente o que está se passando) a caminhar no mesmo passo do cuidador. A perda de controle da situação, do idoso e do meio ambiente só causa mais sofrimento a todos. Portanto, ter paciência é buscar percorrer junto com o idoso todo o processo demencial, do princípio ao fim, sem queimar etapas. Cada dia é um dia diferente. O que pode acontecer é sempre imprevisível.

Quando exercitam a paciência, os cuidadores demonstram compreender o processo vivenciado pelo idoso como o seu próprio caminho e se dispõem a acompanhálo lado a lado. Não é possível forçá-lo a trilhar outro caminho. O cuidador com dificuldade para acompanhar o ritmo do idoso acaba tentando fazer o contrário: que o idoso o acompanhe, o compreenda - o que vai se tornando um processo interacional totalmente insuportável.

A paciência dá sabedoria, dizem os sábios. Só que a vivência dos cuidadores anuncia que não é o tempo que traz a sabedoria. É a compreensão e a aceitação do ritmo do outro que resultam num modo de ser próprio dos sábios:

Está meio difícil, mas tem que saber entrar no meio deles, não levar tão a sério, entender aquela doença. Uma hora ele está como uma criança, uma hora ele fala coisas que não têm nexo. A gente tem que se adaptar àquele mundo; é meio difícil. Eu me sinto... Eu me sinto bem, até! Não sei se é porque eu já lidei com bastante idosos, então eu me sinto bem. Mas tem pessoas que não têm paciência e tem que ter bastante paciência e amor para cuidar dessas pessoas, bastante amor; e levar na brincadeira. Na hora da brincadeira, é brincadeira; hora séria é séria. E assim nós vamos cuidando dele. Você vendo que ali não tem jeito, mas que é viver, no correr do dia. Eu estou me sentindo bem.

O enfrentamento de ritmos diferentes (o do cuidador e o do familiar que desenvolve processo de demência) no cotidiano da relação desgasta o cuidador, mesmo o que oferece total dedicação, deixando-o no limite de suas próprias forças. Ele então se mostra como pessoa que está precisando de atenção, como veremos a seguir.

\section{QUINTA UNIDADE DE SIGNIFICADO: O CUIDADOR ESTÁ TENSO, CANSADO E LIMITADO NO SEU LAZER PORQUE ASSUME A OBRIGAÇÃO DE CUIDAR DE SEU FAMILIAR QUE APRESENTA GRANDE DEPENDÊNCIA}

A limitação que o cuidador sente não é apenas a impossibilidade de ir e vir sem dar satisfações; é a consciência de que qualquer descuido ou falha pode determinar o agravamento do doente, porque este, sim, é que está privado da liberdade de autodeterminação. E o pior é que toda essa dedicação não garante que consiga a reversão da situação do seu ente querido e não vai evitar a sua morte: 
Ah! Tem dia que enche o saco, que eu estou cheia, sem memória, cuidar de casa, cuidar de filho e cuidar de sogro... Tem dia que eu queria viajar, num carnaval, num ano novo, não tem nem por que, por que ele vai ficar com quem? A filha nem esquenta. Às vezes passa assim, nem entra lá dentro para ver ele. Quer dizer: tudo isso vai agravando na mente dele.

O idoso que desenvolve um processo de demência é uma pessoa que vai progressivamente se tornando totalmente dependente do cuidador, como já foi evidenciado. Muito cedo o cuidador percebe que vai precisar se responsabilizar por essa outra vida:

Embora a gente saiba que a minha família é muito grande, mas todos têm problema - trabalham fora, têm filhos pequenos... [Ao fundo, a mãe grita seu nome.] Tá vendo? Tá me chamando... é assim o tempo todo. Os outros não podem dar a assistência que ela precisa, porque a assistência pra ela tem que ser o dia todo e a noite toda, então eu nem durmo mais na minha casa. A gente tem que ficar de plantão.

O que o cuidador percebe como grande limitação, na verdade, é a impossibilidade de organizar um esquema de suporte para seu idoso. E mesmo que consiga estruturar um eficiente sistema de apoio, ele não se desliga de seu familiar, ainda que esteja longe, passeando:

Eu não queria internar, porque eu sei que não é uma boa... Agora, nós estamos vendo o que é melhor para poder me dar chance de viver, porque eu só vivo em função dela. Não saio. Hoje, pra vir aqui, meu irmão teve que deixar de trabalhar para ficar com ela. E eu saio e fico preocupada, se ela está bem em casa, se não está. Então eu não saio tranqüila. Não saio.

A vida do cuidador, embora tenha sempre novos desafios com a situação de seu familiar doente, precisa ser totalmente planejada e organizada no que concerne a todas as atividades. Esse fato limita um pouco a possibilidade de quebra de rotinas ou mudanças de planos:

Não saio, não passeio, porque não vou deixar ela. Quando é passeio que eu posso levá-la, eu levo, mas tem passeios que não levo. Agora, quando passeio, ela fica uma coisa na rua, quer sentar, quer fazer xixi, quer tudo! Às vezes, quero dar uma volta, mal saiu, assim, quer sentar, não fica... Em casa, ela anda atrás de mim no corredor, e quando sai na rua, é esse problema!

Os desejos do cuidador ficam bastante limitados pelo que é possível realizar. A consciência dessa limitação gera grande insatisfação. Só é possível enfrentá-la passando pelos processos já descritos anteriormente: aceitação, exercício da paciência e superação.

\section{Sexta unidade de Significado: O CUIDAdor Re CONHECE A NeCESSIDADE DE SER CUIDADO TAMBÉM PORQUE ENFRENTA DIFICULDADES PELA INTENSIDADE DA OCUPAÇÃO DE SEU TEMPO E DE SUAS EMOÇÕES}

Os cuidadores demonstram ter consciência de que se não estiverem bem de saúde não poderão suportar a intensidade da ocupação de cuidar. Mesmo que não 
estejam tendo tempo para atender a si próprios adequadamente, preocupam-se com isso e apontam o desejo de receber atenção:

Claro que isso está matando a gente, eu e minha irmã estamos nos arrasando. Eu tenho problema sério de coluna, eu tenho problema de estômago, de pressão, então está acabando comigo, mas mesmo assim eu vou ficando até o dia que Deus quiser, que enquanto eu ficar em pé eu vou fazendo. Ah, vou! Tanto é que às vezes, quando a gente pede para um outro irmão ficar e ninguém pode, então tá bem, eu fico, vou ficando, vou dobrando, e a gente trata ela com carinho...

Apesar das preocupações consigo mesmo, para o cuidador é difícil manter um equilíbrio entre a ocupação de cuidar de seu familiar idoso e o seu próprio cuidado, pois ele não dispõe de estruturas de apoio nem familiares, nem comunitárias e muito menos institucionais:

Meus irmãos e eu tivemos uma reunião pra decidir o que fazer. Eu queria até internar, porque eu não estava agüentando mais, e aí conversaram e não chegaram a conclusão nenhuma, aí achamos melhor colocar uma pessoa pra me ajudar pelo menos a cuidar dela, as outras coisas eu faço. Nós estamos procurando, só que é muito caro. O pessoal pede muito. Eu já estou esgotada.

Eu estou num estresse muito grande agora. E outra coisa: a gente não encontra uma pessoa que ajude porque, por mais boa vontade que você tenha, você fica cansada. Eu fico todos os meus fins de semana com ela. Então isso é muito cansativo.

Os depoimentos demonstram que muitos cuidadores chegam a situações-limite por falta de apoio material, físico e emocional. Algumas vezes por não perceberem seus próprios limites, outras vezes por absoluta falta de opção: não há com quem contar para ajudá-los.

Eu me sinto sensibilizada com o problema dele, tenho pena dele e tem hora que eu me aborreço, porque eu também tenho vários problemas. Eu tenho artrite. Agora eu estou melhor, eu tenho estado melhor, mas eu não saía da crise, porque eu tenho glaucoma, eu não posso usar remédio que tem cortisona, esse remédio forte, né?

O cuidador exercita com seu familiar uma atenção que o ocupa todo o tempo, no cotidiano. É uma situação em que se assume tudo pelo outro e em que se cria dependência, e não há como evitar que isso aconteça à medida que a doença avança. Mas também o cuidador sente a necessidade de desenvolver consigo mesmo uma atenção que o faça amadurecer e crescer como pessoa. Muitas vezes, tal necessidade é maior do que a de desenvolver um cuidado com o próprio corpo cansado.

\section{Considerações Finals}

Meu propósito, ao me lançar a este estudo, foi o de compreender o que o cuidador revelou: facetas do significado de cuidar de um familiar idoso que vivencia um processo demencial. 
Nesta investigação, foi possível demonstrar que é fundamental para a atenção ao idoso que seus familiares sejam vistos nas suas singularidades. É como seres singulares que precisam ser ouvidos, suas necessidades detectadas e, a partir deste diagnóstico, receber cuidados.

Os cuidados a serem prestados aos familiares dos idosos em processo demencial devem garantir apoio à sua desgastante tarefa. Esse apoio não significa apenas transmitir informações sobre a doença e orientações gerais sobre o cuidado. Não se podem considerar os cuidadores meros cumpridores de orientações padronizadas. Pois, quando se tratam pessoas como objetos de prescrições, anulam-se as possibilidades de serem elas mesmas livres para tomar decisões e exercitar a criatividade.

É preciso que os profissionais da saúde compreendam que o fato de os cuidadores cumprirem as prescrições e orientações não significa que as necessidades do idoso estejam plenamente atendidas. $\mathrm{O}$ ideal é que tais pessoas participem das decisões sobre os rumos da assistência ao idoso, sabendo que contarão com o suporte técnico.

Quando os cuidadores contam com uma estrutura de apoio institucional, estratégico, material e emocional, têm a possibilidade de exercer o cuidado e permanecer inseridos socialmente sem imobilizar-se pela sobrecarga determinada pela difícil e estafante atenção ao doente em processo demencial.

Um cuidador que recebe apoio adequado busca aprender e descobrir novas estratégias para lidar com o seu ente querido, reduzindo os desencontros entre as necessidades de ambos. Com isso, é possível que aprenda a fazer ajustes no seu cotidiano e não anule as suas próprias possibilidades de continuar a ter uma vida própria.

O estudo evidencia que a família precisa receber atenção específica dos profissionais da saúde. E lidar com essa clientela exige um conhecimento que inclui aspectos teóricos e metodológicos da forma de abordá-la levando em conta sua estrutura e sua dinâmica próprias. Esse tipo de conhecimento ainda é muito precário na área da saúde em nosso país.

Embora muitas vezes o desespero, a angústia, o turbilhão de emoções que emergem da vivência dos cuidadores possam se apresentar como prioridades para o profissional da saúde que os atende, é preciso estender a atenção para além destas manifestações emocionais e atingir as suas demandas objetivas.

O que os cuidadores familiares revelam é que, mais do que compreensão, precisam de apoio estratégico e institucional, pois suas necessidades não são apenas de ordem emocional. São necessidades objetivas e subjetivas, como a de poder contar com estruturas confiáveis para acompanhar o seu familiar idoso e atender a eles próprios, que se esgotam e necessitam de atenção. A solução seria a existência de estruturas sociais e institucionais para apoiar o cuidado ao seu familiar idoso.

Atualmente, além de tais estruturas não existirem, os profissionais da área da saúde ainda demonstram outras dificuldades, que incluem problemas na detecção dos casos de demência, o desconhecimento sobre como lidar com o idoso em processo demencial e de como apoiar a sua família.

Os cuidadores demonstraram também que, com toda a dificuldade e mesmo sem apoio, conseguem cuidar fazendo adaptações que geram grandes custos materiais e comprometem a sua saúde física e mental. Mas fica evidenciado que, se tivessem apoio 
profissional que os auxiliasse a descobrir as melhores estratégias para lidar com seu familiar, além de suporte material, institucional e/ou comunitário, teriam a possibilidade de prevenir maior desgaste de sua saúde e qualidade de vida, garantindo ao idoso uma assistência adequada e livre de riscos.

\section{ReferênCIAS Bibliográficas}

BARCLAY, L. Clinical Geriatric Neurology. Pennsylvania: Lea e Febiger, 1990.

BEAUVOIR, S. A Velhice. Rio de Janeiro: Nova Fronteira, 1990.

BRASIL. Ministério da Previdência e Assistência Social. Plano Integrado de Ação Governamental para o Desenvolvimento da Política Nacional do Idoso. Brasília: Secretaria de Assistência Social, 1997.

BRASIL. Ministério da Saúde. Política Nacional de Saúde do Idoso. Diário Oficial da República Federativa do Brasil, 237-E:20-244, 13 de dezembro 1999.

CALDAS, C. P. O Sentido do Ser Cuidando de uma Pessoa Idosa que Vivencia um Processo Demencial, 2000. Tese de Doutorado, Rio de Janeiro: Escola de Enfermagem Anna Nery, Universidade Federal do Rio de Janeiro.

CASSEL, C. et al. Geriatric Medicine. 2.ed. Nova Iorque: Springer, 1990.

DUARTE, M. J. R. S. Internação Institucional do Idoso: assistência à saúde em geriatria no setor público, 1991. Tese de Doutorado, Rio de Janeiro: Escola Nacional de Saúde Pública, Fundação Oswaldo Cruz.

HEIDEGGER, M. Ser e Tempo. 5.ed. Petrópolis: Vozes, 1995.

KOSBERG, J. I. (Ed.) Family Care of the Elderly. Newbury Park: Sage Publications, 1992.

MENDES, P. B. M. T. Cuidadores: heróis anônimos do cotidiano, 1995. Dissertação de Mestrado, São Paulo: Pontifícia Universidade Católica de São Paulo.

VERAS, R. P. País Jovem com Cabelos Brancos: a saúde do idoso no Brasil. Rio de Janeiro: Relume-Dumará, 1994.

WITMER, D. M. Geriatric Nursing Assistant. Nova Jersey: Prentice-Hall,1990. 


\title{
4
}

\section{A Cultura do Medo e as Tensões do Viver a Cidade: narrativa e trajetória de velhos moradores de Porto Alegre ${ }^{1}$}

\author{
Cornelia Eckert
}

Este artigo trata do cotidiano de velhos habitantes de Porto Alegre, com base em suas reconstruções narrativas das experiências temporais que delineiam trajetórias de vida. Refere-se a uma população de segmentos médios que, de alguma forma, experimentou as transformações urbanas da localidade e compartilhou de interpretações sócio-históricas e políticas em numerosas modalidades de simbolização: meios de comunicação de massa, focos de sociabilidade formais e informais etc.

Tomamos as narrativas como a maneira singular de problematizar o caráter temporal de experiências de vida, exteriorizando valores interiorizados cotidianamente pelo sujeito-narrador, evidenciando a complexidade das tramas cotidianas de inserção nos contextos sociais, da negociação dos papéis e 'performances' demandados e do desempenho no ato comunicativo/vivido. Trata-se de "redescobrir a autenticidade do sentido graças a um esforço de desmistificação", nos termos de Paul Ricoeur, tentando compreender o que descreve, para descobrir seu sentido, "um método, portanto hermenêutico ou interpretativo" (Ricoeur, 1988:3-4).

A narrativa das experiências que analisamos aqui dizem respeito à configuração de uma cultura do medo na cidade com base no trabalho da memória, evocando no presente suas experiências que processam as feições dos medos assimiláveis aos 'dramas culturais' (Turner, 1974), na tentativa de exprimir o sentido 'dizível' da existência e da vida, tecendo na memória narrativa um sentido cultural que ultrapasse o caráter episódico de experiências vividas.

Os relatos contrastam um cenário de violência no tempo atual com lembranças do passado, abordando de múltiplas formas o tema do medo, mapeando nos jogos descontínuos/contínuos de suas representações imagens da cidade-contexto em que constroem sua "identidade como geração"” (Lins de Barros, 1995:92). No processo de atualizar suas interpretações sobre a cidade que contextualiza suas experiências de vida, as feições dos medos tomam múltiplas colorações. Nesse repertório simbólico de viver numa cidade violenta, não raro reafirmam as representações envoltas por um discurso de 'poder' sobre o agravamento das situações de violência e uma dinâmica criminal, divulgado sobretudo pela mídia. 
As notícias restritas às características de criminalidade certamente não cobrem toda a complexidade da problemática da violência urbana no mundo contemporâneo, no qual devemos considerar ampla gama de aspectos que exercem impacto sobre a qualidade de vida: problemas historicamente mais recentes ou mais antigos, como a poluição do ecossistema, o desemprego, a miséria, a corrupção, as disputas pelo poder doméstico e/ou público (violência doméstica, rivalidade entre gangues, disputas por honra familiar etc.) que geram violência e vítimas fatais.

Entre todos, são os crimes que transformam os habitantes em vítimas em potencial, como o crime contra o patrimônio e os crimes contra a pessoa "em que o agressor faz uso da força para causar dano a alguém” (Tirelli, 1996:29), que são considerados os componentes que englobariam os demais em níveis de significação na formação de uma "cultura do medo". ${ }^{2}$

As pessoas são roubadas, assaltadas, agredidas etc. Esses acabam sendo os maiores temores e as indagações reflexivas cotidianas de segmentos médios urbanos destituídos da liberdade celebrada na modernização. Vítimas ou não de perigos reais (incidentes/acidentes), adotam estratégias de proteção e criticam a falta de sustentação da ordem cotidiana por autoridades civis.

Estudos e reportagens constatam que, não raro, quando se questionam as causas da violência no imaginário da população, a tendência é conceber o 'inimigo’ na figura genérica do 'pobre bandido', o 'outro', que ameaçaria uma irreversibilidade na crise urbana. $\mathrm{O}$ deslize para um sistema de acusações é perigo ideológico iminente. ${ }^{3}$

Nesse sentido, é a população do segmento médio brasileiro, que sempre buscou proteger seu patrimônio num contexto fragilizado pelas desigualdades sociais, que hoje mais se depara com o aumento da violência urbana como um "neoconflito" (Ricoeur, 1988:149), uma nova determinação social pelo risco iminente, em sua rotina, da ameaça à sobrevivência física pela criminalidade desmesurada em que transparece a globalização do crime organizado. Cada vez mais recolhidos em seus nichos gradeados, eles clamam por macrossoluções, enquanto mergulham no sentimento de impotência, sem sair da passividade.

Porto Alegre, ${ }^{4}$ nesta passagem de século, é uma polis, uma urbe; enfim, uma metrópole com seus quase 1.500 .000 habitantes. Sua modernidade vem sendo figurada em logotipos, funções e status como a 'capital do Mercosul', primeiríssimo lugar em qualidade de vida entre as demais capitais brasileiras. Sua imagem internacional é, hoje, a de 'cidade democrática', inserida na civilidade apregoada pelos ideais da 'Razão': o progresso, por um lado, e os ideais do individualismo, por outro.

Uma análise dos conteúdos dos jornais gaúchos (de 1997 a 2000) permite observar, no entanto, que eles sistematicamente repetem matérias que prognosticam que o Rio Grande do Sul está 'doente', 'enfermo', ou que "a violência mandou o estado para a enfermaria", ocupando o estado hoje, conforme o Ministério da Justiça, o segundo lugar no ranking nacional de vitimização, passando à frente do Rio de Janeiro nesta quantificação nada meritória e perdendo apenas para São Paulo, que tem uma população 3,6 vezes maior. ${ }^{5}$

"O ano 2000 nasce batizado pela violência crescente", divulga a imprensa, denunciando uma "explosão de violência" sem par no estado e em destaque na cidade de Porto Alegre. A população é roubada na rua, em automóveis, nos ônibus, no trabalho e em casa, situando "um estado que se orgulha de sua qualidade de vida nos níveis das 
regiões mais violentas do País"(Zero Hora, 31/10/2000). "O crime desafia autoridades", destacam as manchetes sobre a violência local ao longo do século (Zero Hora, 20/8/2000).

As reportagens analisadas indicam que os moradores porto-alegrenses (em sua maioria de segmentos médios) estão amedrontados e revoltados com a falta de atitude dos poderes dirigentes quanto a uma política mais ostensiva e protetora contra o crime organizado, o tráfico de drogas e o crime contra o patrimônio.

Os dados jornalísticos delineiam um mapa de inseguranças no estado em que a violência seria a epidemia de uma desordem que situa o indivíduo e a coletividade num processo de aceleramento de transformações históricas geradoras de inquietações e angústias coletivas.

O conteúdo dessas reportagens adquire um clima ainda mais caótico quando elas são comparadas com as seções dedicadas a noticiar o passado porto-alegrense, destacando, no 'túnel do tempo', um clima urbano dos anos 50 aos 70 compassado por referências humanitárias, quando "existia um equilíbrio entre a vida familiar e a coletiva”. O culto à ordem no passado recente destaca os segmentos médios que valorizariam o convívio familiar, quando eles sentiam-se seguros para ocupar as ruas do Centro para os footings na Rua da Praia, ${ }^{6}$ as festas e os concertos no Parque da Redenção, as reuniões nas calçadas e as rodas de chimarrão ao entardecer, temas de predileção de cronistas e poetas do passado.

São, sobretudo, os velhos habitantes que testemunham de forma privilegiada essas passagens descontínuas do tempo, as mudanças que tematizam as crises como vividas, constitutivas de sistemas de representações e de valores em vigor em todas as ações e práticas cotidianas.

Assim, sugerimos que os entrevistados, ao refletirem sobre a crise dos tempos na cidade, reavaliem sua própria identidade de cidadão, configurando a construção de sua identidade citadina como um processo de crise de identidade. Mas essa reflexão sobre a identidade emblemática do ser porto-alegrense é compassada pela interpretação da passagem do tempo. É vista a partir de uma trajetória de envelhecimento do eu e de transformações de valores geracionais e no âmbito em que a noção do eu é repensada.

Da mesma forma, eles se deparam com outros imperativos socialmente determinantes, como o de se apreenderem como 'idosos' numa cidade violenta, uma vez que "o curso da vida é construído em termos da necessidade antecipada de confrontar e resolver essas fases de crise" (Debert, 1999:53).

Trata-se de pessoas que pertenceram a uma geração que vivenciou essas transições incorporadas no processo de construção social da identidade de pertença. Privilegiamos, pois, uma idéia de geração que é "menos marcada pela idade das pessoas que a compartilham do que pela vivência de determinados eventos que marcam trajetórias passadas e futuras" (Debert, 1999: 52). ${ }^{7}$

A população analisada define seu estilo de vida como o de segmentos médios, ${ }^{8}$ com suas trajetórias motivadas por projetos de vida cuja condição econômica e social é construída com base na educação e na profissionalização muito mais do que na posse de capital ou de propriedades. Ela constrói, de modo geral, uma auto-imagem de grupo emergente assalariado, adotando perspectivas políticas, gostos diversos com base em anseios sobre posições sociais que conformam o pensamento contemporâneo. 
Os agrupamentos médios se caraterizam por diferenciações internas complexas de pertencimento a redes de interesse e grupos morais diversos, cuja imagem mais generalizadora pode definir sua inserção na classe média 'baixa', 'média' ou 'alta' conforme a renda salarial capaz de sustentar uma qualidade de vida que permita a execução de projetos familiares de modernização e ascensão sociocultural bem delineados, que vão desde a educação básica até a capacidade de financiar hábitos de consumo para além da cesta básica, diferenciando-se, assim, da grande maioria de baixa renda. Tal diferença não se vislumbra apenas na renda, mas também nos papéis sociais de autoridade, influência e poder, em geral conquistados a partir de um capital cultural. ${ }^{9}$

A aproximação com os entrevistados partiu da rede de amigos e conhecidos dos familiares de alunos envolvidos na pesquisa, tendo por critério inicial sua residência em bairros centrais há um tempo considerável e sua disponibilidade em nos receber como pesquisadores, indagando sobre suas histórias de vida. Após a concordância, as visitas ocorreram em suas residências. Quando se tratava de um casal, conversamos com ambos simultaneamente, na maioria das ocasiões. Em alguns casos de entrevistas com vídeo, foram filmados seus percursos de rotina e situações de convívio nas ruas do bairro.

Entre os entrevistados (aqui citados com nomes fictícios), aqueles que não são nascidos em Porto Alegre vieram do interior do Rio Grande do Sul ou de outros estados para esta capital nos anos 30, 40 ou 50, tendo, portanto, uma trajetória pessoal significativa nesta cidade. Dentre os entrevistados homens, todos estão hoje aposentados, enquanto a maioria das mulheres entrevistadas é dona-de-casa, desempenhando tarefas restritas ao círculo doméstico. Mas duas também vivem a experiência da aposentadoria, após uma vida ativa de trabalho assalariado como professoras.

\section{Narrar a Cidade com Medo}

D. Crista tem hoje 92 anos. Mora com familiares em uma casa de alvenaria com pátio em bairro de classe média, na cidade de Porto Alegre. Estimulada a refletir sobre sua trajetória de vida, discorre longamente sobre sua vivência familiar em pequena cidade do interior, ao longo de sua infância e adolescência. O casamento e a carreira do marido são citados como os motivos para a mudança para Porto Alegre na década de 30, onde 'criou raízes'. Iniciamos com sua fala para realçar, nas suas reminiscências, o contraste entre um tempo passado e um tempo atual, buscando ordenar seus sentimentos em relação aos temores de viver na cidade de Porto Alegre hoje.

Naquele tempo era uma vida bem simples, né? Bem pacata, mas num ponto era melhor. Não havia violência como há hoje, né? As crianças saíam, brincavam de noite na rua, a gente sentava na calçada... até tarde da noite. E hoje em dia... Vai sentar na calçada hoje? Deus o livre... Vai ficar com a casa aberta sentada na rua? Tá pedindo pra ser assaltada, né? Naquele tempo, não. A gente sentava, tomando chimarrão, as vizinhas vinham tudo, sentava na frente. Nossa! Quantas horas a gente ficava até a meia-noite sentado na frente, conversando. Mas capaz que dê pra fazer isso hoje! Mas nunca, né? As crianças brincavam na rua de noite, saíam, 
vinham pra casa. E a gente não tinha preocupação, não havia mesmo, isso é uma pura verdade. Pelo menos onde eu morei. Não tinha essa bandidagem, não tinha mesmo. A gente conhecia a vizinhança, criançada brincava, de noite saíam, brincavam na rua, vinham... Hoje, não... Os netos saem e a gente fica preocupada, né? Botou o pé pra fora, não sabe se volta. Ai, que coisa triste! Eu, cada um que sai, eu faço uma carga de oração. De verdade! Cada um que sai eu rezo. Pra que volte sem problemas, né? Porque eu acho que tem que ser assim mesmo. Só Deus pra nos salvar. Eu não tenho esperança... Cada vez aumenta mais essas coisa ruim, né? Porque era um tempo muito bom, era um tempo com pouco progresso, mas era muito bom por isso. Muita paz... e segurança. A gente não tinha medo das coisas, né? Ladrão era só de noite, arrombando janela das casas, e assim mesmo era muito pouco, não tinha assim como tem hoje. Hoje roubam, assaltam de dia. Não, naquele tempo arrombavam uma... 'Sabe, vizinha, arrombaram a loja do seu fulano, entraram pela janela!' Ah, mas aquilo era uma coisa, um acontecimento! E era uma coisa que acontecia assim lá uma vez que outra, né? Às vezes faziam isso. Faziam buraco na parede pra entrar, né? Mas hoje não precisa, entram porta adentro que... [risos] que a gente estranha, né? Puxa vida, e como!

Vê hoje que tá tudo povoado. Esses... esses condomínio que eles fizeram aí, essas coisas, tudo isso não tinha, né? Porto Alegre cada vez cresce mais, fica mais bonita, né? Não tinha nada disso... Hoje tá tudo uma beleza. Vai, vai melhorando, cada dia melhor, e o progresso avançou muito ligeiro. Pra esse lado aqui - não sei dos outros, porque eu não vou pra lá. Mas pra cá, barbaridade, como desenvolveu! Porque aqui, até Alvorada, é cidade hoje, é asfaltado e tudo que não era. Era uma poeiragem triste na estrada. Hoje tudo tá que é uma maravilha... Sempre gostei daqui.

O ponto de vista de D. Crista revela o paradoxo de viver o tempo vertiginoso da cidade moderna que intensifica os estranhamentos e os distanciamentos entre as pessoas nas esferas públicas e nas esferas privadas, construindo rupturas e fragmentações intensas no exercício da arte de conviver. Trata-se da ambigüidade entre os discursos que consolidam uma admiração da racionalidade urbana (o progresso econômico como valor ideológico) e as complicações da experiência vivida pelas crises consubstanciais ao sistema e à imagem da catástrofe total dos valores e virtudes sociais.

D. Crista caracteriza hoje um estilo de viver em Porto Alegre com base no caos de um tempo presente, reportando-se ao passado, na sua condição de pertencer à classe média, uma ordem mais sólida. A consciência da desordem vem das sensações de rupturas inéditas e imprevisíveis na sua própria cidade, onde as pessoas empreendem mil maneiras de se proteger, constroem muros e grades em torno de suas casas e aos idosos é recomendado evitar circular em certos locais, em determinados horários: o deslocamento solitário. A experiência de envelhecimento é, cada vez mais, alijada de dinâmicas interativas (o vizinhar, o passeio livre, a caminhada descomprometida), sendo prisioneira do pessimismo sobre os itinerários dos membros da família, restando-lhe a preocupação presenteísta com a sobrevivência dos netos que circulam nesse contexto urbano hostil, frustrando-lhe o exercício de projetar um futuro seguro para os seus.

Sem dúvida, é de seu lugar de velha habitante que ela reflete sobre o sentido das transformações urbanas, uma crise que "não existia antes": a violência na sua proximidade e banalidade, perturbadora de associações projetivas. É como idosa de uma con- 
dição de vida 'média' que avalia a desfiguração de ordens temporais almejadas como contínuas. Entretanto, na condição de filhos de Cronos que somos, o próprio envelhecimento a põe em confronto com a dialética temporal do viver como transformador da imagem de si em face da vulnerabilidade de novas rupturas na continuidade, até a própria morte. A experiência de envelhecer é também o processo de constituição da experiência temporal dos sujeitos, percurso de lembranças e esquecimentos, de linguagem e silêncios, de escolhas e desistências, mas que requisitam seu olhar avaliador e seu gesto recriador, em cada palavra do trabalho da memória, que é o trabalho de tomada de consciência.

A imagem da cidade evocada no presente é também o contexto que dilacera suas experiências de envelhecer e fragmenta seu reconhecimento como sujeitos da história da cidade que lhes aparece cada vez mais desencantada pela violência progressiva. Neutralizados como agentes de transformações, os velhos habitantes percebem-se ameaçados pelo esquecimento na cidade divulgado na mídia, que os sujeita à indulgência compreensiva na simplificação demagógica do estado de arte da criminalidade e da vitimização noticiados.

Sugere-se, entretanto, que a crise postulada é também uma crise de interpretação que permite outras interpretações dos velhos habitantes que, ao folhearem a memória-contexto de suas vidas, ultrapassam o próprio conflito perturbador ao acomodarem os tempos de desordem em suas narrativas como movimentos incessantes de instauração de sentido, de 'duração' - ou, na significação atribuída pela dialética do ser na duração (Bachelard, 1989), dando aos ritmos temporais vividos um encadeamento lógico e compreensivo.

Em suas reminiscências, D. Crista reordena o vivido embalado por mudanças conflitantes que vão sendo configuradas nos jogos da memória que reordenam as descontinuidades ritmadas por transformações espaço-temporais da 'paisagem urbana' vivida cotidianamente.

Importa menos aqui a condição cronológica que condiciona os sujeitos nessa fase cíclica da vida e mais a riqueza do testemunho que eles trazem de suas histórias vividas, conforme Maurice Halbwachs (1968), o teórico que diferenciou a memória coletiva da memória histórica com base num pertencimento afetivo à comunidade da lembrança, elucidou ao destacar nos velhos o privilégio de guardiães da memória por deterem de forma mais viva e presente que os demais adultos e crianças as referências dos quadros sociais da memória.

É nos jogos da memória e do trabalho da imaginação criadora humana que podemos recolocar a experiência de envelhecer na vida temporal da cidade numa dimensão de múltiplos significados, explodindo o modelo linear da imagem do homem moderno configurado no processo de individualização que 'coloniza' ${ }^{10}$ as etapas etárias e institucionaliza o curso da vida. ${ }^{11}$

Os velhos habitantes de Porto Alegre entrevistados se situam como narradores da memória coletiva da cidade ou da consciência coletiva do viver a cidade, com base em seus singulares percursos individuais e familiares. Com suas vozes cognitivas, refletem sobre a fragmentação que o medo e a insegurança vão provocando nos seus mapas mentais afetivos nas territorialidades de pertencimento: sua rua, seu bairro, suas 
redes sociais, ameaçando de esquecimento as apropriações dramáticas que puderam realizar na vida urbana em seus rituais cotidianos.

Os velhos habitantes narram uma prolongada convivência em múltiplos ambientes da vida urbana local, relacionando dinamicamente o passado ao presente, mapeando uma cidade em mudanças de condutas e atitudes, que comunica seus afetos territoriais, suas incertezas e evitações socioespaciais, as faces de medo e agonias, orientadas pela linguagem socializada e pelas emoções apreendidas, reconfigurando Porto Alegre como repositório de suas memórias-experiências, como nos termos de Walter Benjamin (1986, 1993 e 1995).

\section{Vozes na Cidade}

D. Eulália é moradora do centro de Porto Alegre há 54 anos. Vive em um apartamento amplo de classe média com o marido, Sr. Mauro, aposentado do Exército, uma filha e uma neta. Hoje com 67 anos, ela veio morar ainda menina em Porto Alegre, em função da transferência de seu pai da cidade fronteiriça de Uruguaiana, indo residir em rua próxima ao Palácio do Governo, território que mantém ainda hoje sua função político-administrativa.

Segundo D. Eulália, "naquela época... ninguém trancava a porta”. Quase em tom de lamento, ela lembra que "havia uma plaquinha na porta com o nome do proprietário, todo mundo passava e respeitava" e que antes de entrar as pessoas batiam na porta, batiam palmas ou chamavam pelo nome do proprietário.

Ao falar 'dessa época', conta que só tinha medo da autoridade do pai, e é em termos morais que ela explicita seus cuidados cotidianos: "Não podia sair sozinha, nem eu, nem minha mãe. A gente só saía acompanhada, porque era assim mesmo. Perto do nosso bairro tinha uma zona mal falada", zona rotulada como de meretrício e que era evitada em suas trajetórias diárias.

D. Eulália recorda, por exemplo, os temores de sua época de adolescência:

Naquela época, olha, nunca se ouviu falar em assim assaltar e atacar. Me lembro quando eu fui pro Instituto de Educação, eu já estava com 12 anos. De vez em quando aparecia no instituto um cara, como é que se chamava? Um exibicionista, e ficava se mostrando às vezes pras gurias, mas aquilo era a coisa assim mais chocante que acontecia. Tô te dizendo, a gente saía de casa, as portas eram fechadas assim só com o trinco, e era aqueles trincozinhos que batia, deixava a janelinha pra abrir. Não entravam, não roubavam, todo mundo se conhecia, porque até a miséria era diferente, né? Naquele tempo a diferença era de dinheiro mesmo, de gente pobre, mas eram todos pessoas assim, a gente brincava com os colegas pobres.

Hoje em dia a gente tem medo, se tranca toda. Acho que antes a gente não tinha medo de nada. Hoje, se a gente vai com uma criança pra praça, a gente fica até com medo que roubem, né? Tem que estar sempre de olho.

É igualmente significativa, nas narrativas, a identificação de um certo 'momento', a partir do qual o sentimento de insegurança passa a ditar novas atitudes preventi- 
vas, como "chavear", "trancar as porta", um indicador da presença de medo pessoal ou preocupação por ordens comportamentais e verbais, individuais ou coletivas.

O sentimento de insegurança é experimentado nos pequenos gestos cotidianos de D. Eulália e sinaliza a desintegração de valores que se materializaria nas situações de agressão. Para situar suas experiências e/ou sentimentos de insegurança de viver no mundo urbano, a interpretação é comparativa ao viver na cidade no passado como exercício de significar o presente. Crises de uma época não muito distante que conhecem novas feições.

Todo mundo morava em casas, aí começaram as dificuldades. Começaram a roubar, a assaltar as casas... Então já começavam as pessoas a se fechar em apartamento. Ninguém roubava pobre. Já hoje em dia eles roubam até dos miseráveis. Entram nas casas dos miseráveis e levam tudo... Antes não tinha porque tu ter medo. Se um guri mexia contigo e tu reclamava! Ah! já levantava dois, três homens para te defender. Hoje, não. Não tem ninguém olhando pela gente nem nada.

Dessa forma, a breve harmonia da interpretação que aponta para uma superação de recalcamentos - os quais podem ser extensivos aos conflitos interiores vividos num passado recente (o medo da autoridade, a vergonha do olhar moral do outro) - é compassada por uma outra ordem de embaraços (não necessariamente intimista), que acompanha o sentimento de que, para manter sua posição na rede humana, deve-se deixar novamente "fenecer sua verdadeira natureza" (Elias, 1994:33).

D. Eulália sugere uma transformação importante em relação ao impacto da violência e do temor sobre o cotidiano das pessoas que passaram a recorrer aos apartamentos para maior segurança, ampliando as razões práticas desses símbolos de urbanização e massificação populacional das cidades verticais, idealizados por Le Corbusier como forma de galgar a liberdade individual (Jacobs, 2000). Tal enfoque é reforçado pelo relato do Sr. Mauro: aos 73 anos e vivendo em Porto Alegre desde 1928, morava com sua família (pai militar) no Grande Hotel e no Hotel Majestic antes de se mudar por um período mais longo para a José Bonifácio. ${ }^{12}$ Também militar, exerceu atividades em várias cidades brasileiras, retornando em sua aposentadoria a residir no centro de Porto Alegre, num apartamento em edifício na rua considerada o próprio centro da cidade, a Rua dos Andradas, cognominada de Rua da Praia. Explica que sua opção foi "para maior comodidade e segurança".

Sr. Mauro busca temporalizar um aumento do sentimento de sua vulnerabilidade à violência ao justificar seu receio em percorrer certos lugares em função da violência, contrastando com seus hábitos de passeios no centro da cidade no passado. Nas décadas de 50 e 60, o footing na Rua da Praia era hábito recorrente de um grupo emergente no processo de modernização da cidade: a classe média.

$\mathrm{O}$ adensamento da cidade e o fenômeno urbano que se torna mais complexo (divisão social do trabalho, distinções sociais, êxodo, desemprego) são causas, para o Sr. Mauro, de um estranhamento diante da concentração popular - a imagem do 'outro' na Rua da Praia, no passado, em contraste com o presente:

Da década de 70 para cá. Bom, até 60 ainda se tinha a Rua da Praia, ainda se conservava um pouco, vamos dizer uns $70 \%, 60 \%$ do que era antes. 
Narra longamente passeios com seus pais, o clima familiar dos passeios, os footings, os cafés da época, chocolaterias etc. Época em que Porto Alegre contava com 275 mil habitantes e conhecia uma importante urbanização das zonas centrais e o surgimento de vilas irregulares na periferia.

A quantidade maior era bem arrumado. $O$ pessoal de fora vinha menos ao centro. Mas a gente já começava a notar a diferença, porque uns eram dum jeito e outros eram de outro. O pessoal dessas vilas populares aparecia por aí, se sentia a diferença.

Hoje o pessoal de fora vem mais ao centro, essas vilas populares aí, vem mais. É o perigo hoje. De assalto, de roubo. O pessoal... O desemprego tá começando a crescer, a porcentagem de desempregados. E o pessoal desempregado, com filho, com isso, com aquilo... termina fazendo qualquer negócio.

Hoje aqui na frente, à tardinha, principalmente, seguidamente a gente escuta 'pega ladrão, pega ladrão'... seguidamente nessa Rua da Praia aqui toda. Aqui no centro assaltam muito, roubam muito. É mais gurizada assim, 18, 19, 20 e poucos anos que roubam e um passa para o outro e tal. Depois ninguém sabe quem foi ou não foi. A polícia às vezes anda... Ontem mesmo eu vi a Brigada. Pegou meia dúzia ali, encostou na parede e tava revistando...

A prudência passou a ser uma regra do cotidiano. À luz do dia, eles arriscam o convívio em lugares públicos; já ao escurecer evitam sair, e a entrada de qualquer desconhecido é controlada por um serviço de portaria com vigilância 24 horas, que comunica por interfone interno a presença de um visitante. Uma série de práticas é desempenhada para modular o cotidiano da neta, num quadro de forte segurança. "Eu levo e busco de carro", sentencia a avó.

As estratégias para preservar um estado de segurança é indicativo, pois, de um ato considerado cada vez mais civilizador nas cidades. Não é apenas a rua que é evitada como local favorável aos crimes contra a pessoa, mas a própria 'casa' precisa ser fortalecida e garantida contra as ameaças do mundo criminal. Para proteger o mundo doméstico, a vida privada, apela-se a instrumentos protetores materiais (alarmes contra roubo etc.) e cursos de defesa pessoal. Investe-se em protetores cotidianos (guardas, por exemplo) contra vandalismo, roubos e assaltos. A paisagem urbana de Porto Alegre conhece, assim, de forma acelerada, uma vitalização das estratégias de segurança que vão figurando uma cidade segundo uma estética do medo.

Para Sr. Mauro, o temor que ele sente na rua é motivo para uma certa reclusão, sua e da família, no apartamento. Hoje, a cidade é o grande contexto público que prima pela insegurança e desordem. Ao referir-se à hegemonia de condomínios fechados para classe média, acrescenta:

Ah, hoje o individualismo tomou conta da população. Cada um 'primeiro eu', depois eu, depois eu, depois eu, depois a minha mãe... e olhe lá. E olhe lá... Não, hoje a coisa tá desse jeito. Por incrível que pareça... é verdade.

Sr. Mauro destaca uma importante consequiência do enclausuramento forçado em que se é obrigado a viver nos tempos atuais: o enfraquecimento das relações de vizinhança que implica um decréscimo das relações de amizade e solidariedade. Mas 
relativiza seu pessimismo e seu temor ressaltando sua participação em redes de sociabilidade ao situar seu pertencimento ao grupo de aposentados no Clube Militar, nos encontros periódicos em que se sente "entre amigos", e no grupo de terceira idade da paróquia local.

A crítica ao individualismo exacerbado beirando um narcisismo como metáfora da condição social de nossos dias (Lasch, 1978) traz, interpenetrada no tema da crise, a noção do enfraquecimento dos sentidos de socialização pela privatização, em certas esferas da vida (vizinhança, comunidade, família), das relações tradicionais (hierarquia, solidariedade, reciprocidade). A trama do tempo é a fragmentação dos laços e valores de reciprocidade. A personalidade individualista, diz Sennet (1979), desintegra as relações, fragmenta os sentidos, impondo aos sujeitos uma ideologia da intimidade.

Essa idealização da vida pública no passado, presente mais em Sennett que em Lasch (1978), é um exercício de reflexão significativo nas ordenações temporais dos entrevistados, como revela a narrativa do Sr. Ronaldo:

Eu sempre morei nesta rua. Tá, eu nasci em Passo Fundo e vim pra Porto Alegre com 15 anos [tem hoje 71 anos e sua esposa não informou a idade]. Eu trabalhava no centro mesmo [relato sobre a profissão]. Naquela época, quase não tinha edifícios... Eu tinha um fusquinha que dormia na rua. Eu chegava de viagem e deixava o carro na rua, não tinha problema nenhum e os meus filhos brincavam no meio da rua, só se cuidava do bonde... Era muito tranqüilo... Só era perigoso andar de noite no Alto do Bronze, perto do presídio... Era uma parte mais pobre, mas aqui em cima era ponto nobre. Eu cansei de sair assim, domingo à noite. Eu também trabalhava à noite. A gente saía, jantava e ia passear no centro, olhar vitrine, era um baita programa. Lá pelas oito da noite, eu e minha mulher íamos passear, voltava pra casa às dez horas sem pensar em assalto nem nada. Agora está um terror. Eu andava a pé até duas da manhã e tudo bem. Eu tinha dois empregos e nesse da noite eu voltava pra casa a pé... Olha, eu digo que está perigoso. Nunca fui assaltado, só roubado, numa sexta-feira à tardinha ali naquela praça em frente à Santa Casa. Então eu acho Porto Alegre muito perigosa e violenta. Já pensei em me mudar para a praia. Tá todo mundo fazendo isso... [continua a narrar os motivos pelos quais ainda não consolidou esse projeto].

Sr. Ronaldo e D. Joyce, moradores da Rua Duque de Caxias, no centro da cidade, explicam que todo o edifício é gradeado, mesmo tendo serviço de portaria. Recentemente, o condomínio contratou o serviço permanente de segurança de rua, facilmente identificável nas guaritas que proliferam nas ruas da cidade.

A estética do medo é a constatação material mais figurativa na transformação da cidade, impulsionando seus habitantes, sobretudo os aposentados, a buscar maior segurança. Justamente são os segmentos médios, com um certo poder aquisitivo, que recorrem ao gradeamento de suas casas, edifícios e janelas e à instalação de alarmes em suas casas e seus carros. Os edifícios têm porteiros eletrônicos e as ruas se povoam de exércitos pessoais para vigilância. Seus hábitos e rotinas são igualmente estilizados pela estética do medo, conforme Sr. Ronaldo: 
De uns dez anos pra cá... De noite eu não saio mais, só às vezes, na casa de um filho, mas aí a gente chega em casa e ilumina bem a entrada do edifício pra ver se não tem nenhum ladrão esperando pra assaltar, e já entraram no nosso apartamento antes. A gente morou um tempo na Nilo, é um daqueles edifícios pequenos ali da rua, tem só quatro andares, tem zelador mas não tem portaria permanente. Aí, num dia de manhã, o cara conseguiu entrar, foi no andar de cima, a moça, empregada, abriu a porta e ele entrou, ele estava armado, aí chegou a filha da dona de camisola e ele mandou ela se vestir, era um negrão, né? Ele levou jóias e levou o dinheiro que tinha em casa. No dia seguinte, nós fomos pro parque de exposições de Esteio. Quando voltamos pra casa, eu botei a chave na porta e abri o trinco, virei pra minha mulher e disse pra ela que ela tinha se esquecido de trancar a porta, e ela respondeu que nem bêbada iria esquecer. Nós notamos que o freezer estava desencostado da parede, e ali era uma entrada de ar e ele entrou por ali. Por sorte, a minha mulher tinha fechado à chave a porta que leva pros quartos e o cara não conseguiu abrir, ele só levou um anel que tinha caído no chão e amassou... Eu tinha deixado em cima da geladeira, pra lembrar de levar na relojoaria pra consertar. Depois os caras botaram guarda e grade em tudo, então a cidade, assim... Nesse edifício aqui, em 30 anos houve um roubo só. Foi quando o zelador foi pra um grenal e deixou o edifício. Foi embora, entraram e roubaram. $\mathrm{O}$ fato de ter um porteiro 24 horas não evita o roubo, mas dificulta.

\section{Joyce:}

O nosso prédio lá da Nilo não tinha porteiro 24 horas, então botamos porta de ferro. Essa porta de ferro aqui foi idéia do vizinho. O ladrão te espera. Quando tu chega em casa, quando tu encosta o carro, ele quer entrar junto na garagem. Quando tu vai abrir a porta do edifício a pé, ele está te esperando pra entrar dentro.

Sr. Ronaldo indica um temor muito presente: o atentado ao patrimônio por latrocínio, roubo ou furto. Nas famílias de classe média, cultoras de uma vida privada marcada pelo conforto material e por objetos representativos dos sentimentos burgueses, o ataque ao patrimônio é temor constante. D. Joyce identifica as seqüelas da explosão do crime organizado em Porto Alegre, que configura a década de 80 , e a disseminação do crime pelos bairros, que se acelera na década de 90 e deixa a população em pânico diante de criminosos e/ou quadrilhas cada vez mais armados em práticas audaciosas, como assalto a carros e edifícios. Estes, embora seguros, têm no seqüestro de algum morador ou funcionário ameaçados de morte e lesões corporais a garantia do sucesso da transgressão.

Outro entrevistado, Sr. Jorge, poeta, é apaixonado por sua cidade, por seu bairro. Funcionário aposentado, aos 70 anos em 1997, é proprietário de um apartamento simples em bairro residencial nas proximidades de uma das principais artérias comerciais e de lazer da cidade de Porto Alegre, a Avenida Osvaldo Aranha. Residem com ele, além de sua esposa, um filho e um neto (tiveram cinco filhos e cinco netos). Ele relata longamente seus hábitos um tanto boêmios no centro da cidade, com destaque para a freqüência ao Restaurante Maria, próximo ao mercado público, ponto de encontro de poetas amadores.

É elaborando um jogo contrastante com as recordações de um "passado seguro", com "espírito comunitário", que seu Jorge sentencia ser "a segurança o 
maior problema na atualidade, nesta cidade", desabafo acompanhado por sua esposa (“o maior problema”).

É justamente sua esposa (D. Pérola, 59 anos em 1997) que assinala a presença do valor medo na socialização do seu neto:

Eu tinha pena de assustar, mas aí entraram aqui em casa [relato do arrombamento]... Agora eu não tenho mais pena de assustar, tem que avisar. Meus meninos, quando eram pequenos, eu tinha pena de assustar, porque eu acho que a pessoa viver assustada, né, é horrível. Os meus tipos de susto eram outros. Naquela época, minha mãe dizia: 'Não come isso, ouviu? Isso faz mal!' Minha mãe dizia que manga com água não podia, me metia medo assim, né, que hoje não existe mais, hoje é o medo dessa violência.

Sr. Jorge acentua a adesão ao signo mais presente dos traços de hostilidade e desconfiança em relação ao 'outro' e requisito básico de proteção: a grade de ferro. "Nós gradeamos tudo aqui agora. Já fazia algum tempo que nós pensávamos em colocálas com medo dos assaltos... Aqui na frente é... Nossa! Não existe mais segurança”.

D. Pérola acrescenta:

Uma vez assaltaram nossa filha dentro do carro, saindo de dentro do carro, ela e o namorado. Então vê o perigo que tá essa zona aqui hoje? De uns dez anos para cá... Esta rua é meio caminho de tráfico... Essa mudança dessa atualidade, né, as drogas, modificou completamente... [Segue falando da beleza do Parque Farroupilha, próximo a sua casa, que descreve criticamente como território perigoso, em função da circulação de drogas, do homossexualismo e da prostituição.]

Socializar seu neto com a ameaça permanente de agressões retira do fenômeno da violência seu caráter de anormalidade para situá-lo como estruturante da sociedade. Seu depoimento associa um sentimento de perda de ideais sociais que se fragmentam na poeira do tempo ao crescimento da violência urbana.

Como eu disse ainda há pouco, sabes que até algum tempo atrás existia um pouco de espírito comunitário. Hoje em dia, não existe mais esse espirito comunitário, nós procuramos defender a nossa família. Então a gente procura dar alguma coisa para a comunidade com o exemplo que a gente dá aos filhos, os ensinamentos para que ele não venha a perturbar o outro porque eu, sinceramente, na situação que estamos vivendo hoje nesse país politicamente... Então eu procuro me doar à minha família. Isso não quer dizer que um vizinho vai cair no chão, numa casca de banana, e eu vou passar, e não fazer nada. Não vou menosprezar o vizinho, mas eu não tenho mais condições de freqüentar os outros, conversar assim, vamos melhorar isso [desvia para questões do condomínio], colocar uma lâmpada aqui. Não! Eu tenho que ficar dentro de casa, infelizmente, 'egoisticamente' eu falo. E lamentavelmente todo mundo está fazendo a mesma coisa hoje.

A frustração com que se qualificam as relações de hoje como mais presenteístas mescla os embaraços das experiências subjetivas no mundo moderno, as feições do medo e as estratégias sociais 'necessárias' para evitar oportunidades de agressão. Mas na preocupação com a segurança, o maior temor é quanto à vitimização pessoal. A experiência, de modo geral, é lembrada em detalhes que pressupõem, eventualmente, o 
difícil esquecimento. O casal Zélia e Jonathan já havia passado pela ameaça de vitimização, como seus relatos evidenciam.

Acostumados com as mudanças geográficas exigidas pela profissão bancária, a escolha de morar em edifício em bairro residencial foi opção desse casal, para o enraizamento após a aposentadoria. O bairro Cidade Baixa, evitado no início do século pela sua identificação com comunidades de ascendência africana, mais tarde transferidas para a periferia, passou a abrigar edifícios residenciais para segmentos médios e uma importante vida noturna (bares e restaurantes). Mesmo assim, apresenta ainda hoje raros pontos de barracos concentrados, denominados 'ilhas' de favelas. Essa é pelo menos uma das razões que Zélia sugere para explicar os freqüentes assaltos na parada de ônibus ou no interior do ônibus, experiência da qual foi uma das protagonistas. $\mathrm{O}$ inesperado da situação, explica ela, deixou-a por vários dias amedrontada. A relação sem conteúdo lhe aparece disforme - "levei tempo para passar o susto" - e sua preocupação se volta para horário tardio do retorno de uma filha ainda estudante: "Minha preocupação é com Lúcia, mas agora o noivo tá indo buscá-la e eu fico mais tranqüila do que se ela tivesse ainda que voltar sozinha".

Sr. Jonathan traz em seu relato de atentado uma performance pouco estimulada pelas regras comportamentais sugeridas pela polícia e divulgadas pela mídia para evitar a fatalidade maior: "a reação diante de criminosos impacientes e nervosos e muitas vezes drogados". A intemperança aqui o situa no interior de um habitus masculino, apelando para uma violência lícita pela honra, como podemos interpretar na sua leitura da experiência. A coragem e a valentia constituiriam as ordens de significações possíveis ao imprevisível e ilícito.

Olha, eu fui assaltado várias vezes. Tentaram me assaltar várias vezes, mas nunca me levaram nada. A primeira vez foi aqui bem perto, né? Tinha entrado numa padaria pra comprar pão, e eu carregava o dinheiro no bolso esquerdo sempre, porque eu sou canhoto. E o sujeito meteu a mão no meu bolso direito. Não foi propriamente assalto. Ele tentou me levar alguma coisa do bolso, né? Mas só tinha papel com uns endereços aqui no bolso. Tirou, saiu correndo... Eu vinha com uma máquina de moer carne na mão, soltei a máquina e tentei sair atrás dele, mas o cara era rápido que era uma coisa braba... Disparou. E eu não pude nem... notar quem era. Eu sei que era... o sujeito assim era um... mulato, moreno. Puxando pra preto. O cabelo levantado assim. Um rapaz novo. Porque se locomoveu muito rápido. Eu saí atrás dele e já ia a uns 20 metros, 30 .

A segunda vez também foi aqui perto...

E a outra vez... A outra vez, não sei se foi antes ou depois...

E no mesmo lugar que tinham me tirado o talão de cheque, dessa vez...

Uma vez um garoto...

E agora, não faz muito tempo, eu tava, era um domingo, eu ia atravessando ali, naquele... próximo àquele Largo Glênio Peres, por ali. Eu ia me aproximando em direção à Praça XV, ali, era um domingo de tarde, tava cheio de gente ali, né? Mas tudo desocupado assim, marginais, que ali... freqüentam muito naquela região ali, né? E não havia quase policiamento. E o sujeito me meteu a mão nesse bolso aqui, pra pegar dinheiro, e eu segurei a mão dele também, segurei a mão e apertei e ele tirou a mão, com dificuldade até, e se escondeu atrás duma árvore ali. E eu fui 
atrás dele. Fui atrás dele, e um dos caras que viram ali me aconselharam: 'melhor não ir lá, melhor chamar a polícia, melhor não ir lá que esse cara vai reagir'. Se escondeu atrás duma árvore grossa... Aí eu deixei, não fui chamar nem polícia... Ele não levou nada, também. Só fui quando roubaram o talão de cheque. Mas depois que eu saí, eu fui ver, o meu bolso tava todo danificado.

Eu, se eu puder pegar o sujeito, eu vou estrangular o cara, né? Ou ele me mata, ou eu mato ele. Uma das duas. A minha reação é pegar o sujeito e bater, bater no cara, mesmo que seja de mão aberta assim... Geralmente esses caras andam caindo de magro aí, de pobre, de doente também. Eu, se puder segurar o sujeito, eu seguro. Se eu levar a pior, aí azar meu. Eu não me abaixo pra esse tipo de gente, eu não me abaixo. A minha reação é reagir. Ele nota se a gente fica com medo. Ele nota porque ele tem muita prática disso. E se tu ficar com medo dele e te encolher, eles vêm mesmo pra cima. E se a gente ameaçar e sair atrás dele, eles já sabem que o cara não é assustado, né?

Mas tanta autonomia não se mantém ao longo do seu relato. Ele se rende à sensação de vulnerabilidade em face do imprevisível e "toma precauções". A mudança desses pequenos hábitos vai dando os contornos da estética do medo.

Se nós vamos passear de noite, a gente pega táxi. Chama o táxi aqui na frente. $\mathrm{E}$ se é de dia, não levo algum objeto que eles possam me levar assim, como relógio, ou aliança, eu não levo.

De uns quatro anos pra cá, a gente colocou grade na frente do edifício. De noite, a gente não atende, porque quando é alguma pessoa que quer alguma coisa com a gente, geralmente a pessoa liga antes, né? Eu não sei se tu viste, mas tem grade até na porta. Porque esse edifício aqui, antes de nós virmos pra cá, ele já tinha sido... Por duas vezes entraram nos apartamentos. Então a síndica mandou colocar essas grades de ferro por isso, sabe? Pessoas que trabalham, saem de manhã, só voltam à tarde, chegaram em casa e encontraram o apartamento totalmente depenado, levaram tudo.

Interessante destacar, na narrativa do Sr. Jonathan, o tema do gênero, tão importante nos estudos antropológicos sobre envelhecimento, e as diferenças constatadas nas experiências masculinas e femininas. Percebe-se aqui que, se ao homem é dado maior valor na experiência de envelhecimento por sua situação de rompimento com a vida ativa/aposentadoria, uma vez que a experiência da mulher é de restrição ao mundo doméstico (Lins de Barros, 1995), justamente os homens, de forma mais acentuada, conhecerão os determinantes dessa nova condição de insegurança e temor à vitimização. Acostumados que estavam ao aproveitamento do tempo livre da aposentadoria para o convívio em formas de sociabilidade masculina no mundo público (rua), a opção pela restrição maior ao mundo doméstico torna-se freqüente.

Há, de qualquer forma, uma desconstrução de ordem apreendida e o esforço de construção de enfrentamentos das circunstâncias, táticas cotidianas de resistência, como diz De Certeau (1994), na busca de sentido numa história de mudanças contingentes.

Conheci D. Nora por meio de uma amiga que me dissera que ela estaria para se mudar de sua casa, onde morava há 30 anos com a família, para um apartamento. Abalada com o falecimento do seu marido, falou sobre a decisão de sair da casa: 
Não é que tenha medo de ficar sozinha, mas eu não gosto de ficar sozinha. Não compreendo, tenho amigas que dizem que adoram ficar sozinhas, não precisam de ninguém. Eu sou uma pessoa completamente dependente de alguém... Adoro esta casa, mas também estou envelhecendo, e ficar sozinha neste casarão... é perigoso. Então, para mim, o apartamento fica mais fácil, apesar que vou sentir uma falta enorme da minha casa. Eu amo ela, aqui criei os meus filhos e passaram os anos mais importantes da minha vida. Mas tudo muda. No apartamento, tenho porteiro 24 horas. E aqui teria que ter alguém para vigiar, e aumenta as despesas. No edifício, tem zelador, porteiro 24 horas, porteiro eletrônico, facilita muito a vida e tem mais segurança.

D. Nora apresenta nesse relato a problemática da relação do idoso com sua família, característica nos segmentos médios, somada às estratégias e táticas a serem apreendidas pelos idosos que optam por residir em suas próprias casas. Conta que nenhum filho quis permanecer na residência da família após a idade adulta; o casamento e a independência econômica permitiram a construção de novos projetos familiares. Ela ressalta que esse era um hábito do passado e hoje a 'época é outra'. Destaca então a sapiência do seu marido, que repetia: "Viver não é difícil, o difícil é conviver”. E acrescenta:

Essa gente moça hoje fala muito em seu próprio espaço. Fala-se muito no espaço. Os velhos nunca tiveram espaço, mas agora os velhos estão querendo seu espaço, porque é o espaço de ter realmente o seu silêncio, quando se quer silêncio, de se deitar a hora que quiser, de sair, viajar, um direito que a gente tem na velhice e que se morar com outro não se tem esse direito.

Nora critica filhos que jogam seus idosos em asilos, mas também não quis 'a saída' da casa geriátrica, "pelo menos enquanto eu puder ter autonomia, né?". Uma vez que nos restringimos a entrevistar pessoas residentes em seus próprios lares, entre os entrevistados o recurso ao asilo ou à casa geriátrica é bastante estigmatizado. D. Nora expõe uma série de estratégias tomadas para poder conviver sozinha, com autonomia, "sem atrapalhar" os filhos, mantendo os vínculos familiares e trocas de favor, como a tarefa de cuidar dos netos, situação que desempenhava na hora da entrevista. Explica que, quando sai por tempo indeterminado, telefona para os filhos e avisa sobre seu deslocamento e itinerário. Alega que esses cuidados são importantes, pois quando seu marido ainda vivia, ela sempre ligava avisando do seu retorno, para ser aguardada.

Dava uma buzinada, ele abria o portão e já entrava. Agora tenho essa menina, que é empregada do meu filho, está dormindo aqui provisoriamente. Mas normalmente a esta hora [20 horas] eu já cheguei. Para não arriscar, sabe... Agora, hoje, minha filha passa aqui, me liga, eu ligo, a gente tá sempre se vendo.

Dessa forma, Nora exterioriza um temor de alguma forma presente nas narrativas: poder manter na velhice uma qualidade de vida independente e autônoma, pelo menos enquanto a doença e a perda da consciência de si mesma não lhe imponham a morte social. ${ }^{13}$

D. Raquel, de 60 anos, profissional aposentada, divorciada, que mora em edifício de segmento médio em bairro central, tem uma experiência significativa nesse sentido. Refere-se a ela mesma como tendo sido "uma mulher decidida". Foi a única mulher de 
uma família de imigrantes do interior gaúcho, de predomínio étnico italiano, a enfrentar uma vida de estudos na capital. Na época (1953), recusou uma arma que seu pai insistia que ela usasse para autodefesa. No interior, era comum ter-se uma arma em casa; já em Porto Alegre, disse não achar necessário:

Eu não tinha medo... Meus pais nunca inculcaram na gente o medo, eu não temia as coisas. Eu sempre fui valente, mais arrojada... Não que as pessoas não tivessem medo. Umas amigas que moravam do outro lado do Parque Farroupilha atravessavam correndo porque tinham medo. Mas eu não me lembro de coisas temerosas dessa época. Eu trabalhava na periferia, e tudo como diretora. Diziam que era um lugar de delinqüência. Não tinha policiamento, mas não era perigoso... Enfim, como eu era mais jovem, eu e meu marido, então, não tínhamos medo. Não tinha esse problema de temer ser assaltada na rua. Até uns anos atrás, não lembro de nunca ter medo de andar na rua.

Raquel casou-se e teve três filhos (uma menina e dois meninos; hoje tem um neto). Uma situação de vitimização sofrida por seu filho, segundo ela, foi o início de alguns acontecimentos desagregadores de sua história familiar. Seu filho fora perseguido e assaltado por um "grupo de delinqüentes", a "gangue da Matriz", como foi denominado um grupo de jovens assaltantes que atacavam na região da Praça Matriz, no centro da cidade, o que chegou a ser assunto do noticiário dos meios de comunicação. "Ele ficou muito fragilizado", conta, e foi o início de uma história de depressão que o levou à morte.

Seu relato segue, situando uma segunda ruptura drástica da rotina familiar: a perseguição política, a sua prisão e a do marido. Essa experiência traumática, somada a problemas de saúde, levou-a à prática da ioga como "busca de equilíbrio".

Eu buscava um caminho... Tentei o espiritismo e não gostei. Não sabia o que queria, queria uma filosofia de vida, e aí uma amiga minha me falou do grupo esotérico [grupo denominado Tempo Astral ou Grupo Universal, também chamado simplesmente de grupo esotérico]... Eu agora faço parte. Nós estudamos textos de filosofia de vida buscando um caminho... Era tudo que eu queria na vida, um grupo para estudar junto.

O fortalecimento do sentido religioso (bastante presente em várias narrativas) é tema complexo para ser aqui tratado com profundidade. $\mathrm{O}$ catolicismo tradicional e até a terapia se fazem presentes. Neste caso específico, a afirmação de um crescimento individual busca um rearranjo da vida interior mediada pelos "saberes psis" (Salem, 1992:69), ${ }^{14}$ em contraste com a grande maioria de idosos católicos entrevistados, que se mantêm em redes de sociabilidade católica e em projetos pessoais de devoção à tradição judaico-cristã do amor como auto-sacrifício e ideal de salvação.

$\mathrm{Na}$ sua narrativa, Raquel diz que essa opção espiritual de vida a ajudou em vários aspectos: "Eu, por exemplo, tinha uma arma em casa". Mas passou a superar o medo e desvencilhou-se da arma. E foi, sobretudo, para superar um segundo afastamento (menos drástico) que reafirmou a importância do grupo esotérico, o reencontro com a solidão, quando seu último filho resolveu sair de casa: "Sabe o que é você chegar em casa e ninguém estar te esperando? Ninguém mexeu nas tuas coisas, ninguém te 
esperando, não ter ninguém para conversar em casa, para dividir, alguém que vai chegar e vai fazer um barulho na porta?".

O medo da solidão revela um traço importante da vida contemporânea, que pode ser esboçada por uma cultura privatista, uma vez que se tornou 'um fenômeno endêmico' da vida caracterizadamente urbana. À solidão pública das massas se acrescenta uma dose ampliada de temor à vitimização, encurralando o cidadão nos domínios do privatismo, não só pela hibernação emocional do homem moderno, mas pelo temor da busca de espaços de interações em lugares públicos. No caso das pessoas idosas, esse parece ser um dos maiores dilemas, sobretudo nos segmentos médios, em que o idoso tende a permanecer vivendo só após a partida dos fillhos ou após a perda do cônjuge.

A visibilidade dessa condição solitária é um dos pontos de maior motivação para os programas para a terceira idade angariarem novos adeptos. Também as formas de associação tradicionais, como grupos religiosos, associações e programas para a terceira idade - que, segundo Debert, "são formas de associativismo em que a idade cronológica é um elemento fundamental na aglutinação dos participantes" (Debert, 1999:138) -, mobilizam uma importante população (sobretudo mulheres), em geral promovendo uma sociabilidade lúdica e de reinvestimento de laços afetivos de amizade e convívio social.

O recorte dado à história de Raquel revela como viver na cidade a partir das feições do medo e da insegurança é, paradoxalmente, também captar seu esforço de duração (durée) social na luta contra a desordem e a desagregação social. Como lembra Duvignaud, "não existe nenhuma razão, natural ou não, para que uma sociedade se conserve, salvo justamente a sua cultura, que é o instrumento de luta contra a dissolução" (1983:4). Tal como na mitologia grega, o medo personificado por Fobos e seu irmão Deimos, o pavor, ${ }^{15}$ tem uma irmã chamada Harmonia, que vislumbra o restabelecimento da ordem e da segurança. A interação de Raquel em rede de cultivo espiritual, assim como em outros exemplos citados pelos entrevistados, promove esse exercício de reencantamento da vida.

\section{Insegurança e Cultura do Medo}

Os relatos de como vivem e pensam os velhos habitantes no ambiente urbano marcado pela imagem da violência permitem refletir sobre as experiências de envelhecer nesse contexto próximo à obsessão pela segurança e sobre a generalização do sentimento de medo em todos os lugares sociais.

Ao analisar a preocupação com a vitimização criminal entre pessoas da terceira idade, observa-se que o seu aumento depende da percepção que as pessoas têm de sua possível vitimização. Quanto mais uma pessoa acredita em sua provável vitimização, maior a possibilidade de ela ficar preocupada com o assunto. Vários estudiosos falam, pois, da vitimização subjetiva - a que atinge as vítimas do temor. Esse temor pode ser produzido desde uma realidade objetiva até um menor ou maior grau de subjetividade (Rovinski, 1993). Impactos do viver urbano que podemos já encontrar nas reflexões de 
Georg Simmel, em 1902 (apud Grafmeyer \& Joseph, 1984), sobre o psiquismo do citadino, ao se referir à cidade moderna como o lugar da atitude blasée.

Mas não se trata de conferir ao medo e à insegurança apenas o estatuto de mais um estímulo ao psiquismo a que são submetidos os indivíduos nas grandes metrópoles e "fazem dele um ser com elevada consciência de sua subjetividade e lhe confere, ao mesmo tempo, uma atitude de autopreservação frente aos estímulos recebidos" (Lins de Barros, 1987:17). Tomam-se as feições dos medos como estratégias para tematizar os exercícios de reordenação do tempo vivido no contexto urbano por meio de jogos da memória dos entrevistados, sem perder de vista que "o medo é um fato social que varia segundo os lugares e as situações” (Roché, 1993:41). A cultura do medo vivida pelos grupos urbanos em questão desestabiliza a previsibilidade da cosmovisão de grupos e de suas ações rotineiras com base em referências institucionais e papéis socialmente objetivados. Ocorre, para os habitantes, uma ruptura da liberdade de acessar as diversas redes que consolidam seu universo cognitivo e contextualizam seus atos de socialização que integram suas biografias.

O medo da violência dilacera as previsibilidades que giram em torno das experiências de vida para dinamizar as ações cotidianas e coloca em xeque as projeções de trajetórias na vida urbana. Previsibilidades ancoradas num capital cultural e num mapa simbólico tão importantes na auto-interpretação coletiva que representa a concepção comum, interna, da comunidade, segundo Schutz (1979). Essas previsibilidades são ameaçadas pela perda de orientação de suas antigas noções relativas à conduta diária. O medo da violência urbana se coloca, assim, como tendo uma relevância imposta aos citadinos pela força com que participa do cenário cognitivo do mundo da vida - contendo, portanto, uma "relevância temática" (Schutz, 1979:23). Ou seja, os indivíduos, diante de uma situação problemática, precisam se preocupar em reconhecer o problema e, com base nessas atividades cognitivas e 'interpretativas', desenvolver estratégias para resolvê-lo. Assim, o medo da violência urbana passa a fazer parte da herança da comunidade cultural a ser transmitida às gerações mais novas.

O sentimento de insegurança pela imprevisibilidade se coloca como um problema relevante, que obriga os sujeitos, especialmente os idosos, vítimas em potencial nos espaços públicos dos descuidistas ou dos trombadinhas, a traçar novos procedimentos de sua rotina, incluindo os projetos de agir, numa dramática cotidiana. Os idosos, portanto, aparecem como uma população bastante propensa a desenvolver sentimentos de receio e desamparo diante da impossibilidade de agir.

Seguindo a teoria das tipificações de Schutz, pode-se sugerir que o medo "define a situação"16 e conglomera o duplo caráter da motivação: "os motivos a fim de", essencialmente subjetivos (que prescrevem as tentativas idiossincráticas do indivíduo de se orientar), e "os motivos por que", os quais indicam "as razões dos homens para as suas ações enraizadas em experiências passadas” (Schutz, 1979:49). O medo é, assim, um elemento perturbador não só da concretização de projetos de vida mas da própria elaboração de novos projetos pessoais, dada a sua incorporação como emoção preponderante na "experiência da dúvida" (Schutz, 1979), uma vez que são as emoções a base do processo da construção de projetos pessoais-sociais. ${ }^{17}$ 
É o exercício de idealizar ações e planejar o futuro, característico das dinâmicas de estilo de vida de segmentos médios urbanos, ${ }^{18}$ que os citadinos percebem ameaçados de ruptura motivada pelo sentimento de medo, insegurança e pânico associado ao risco do livre ser nas esferas pública e mesmo privada de sua existência.

Mas importa abordar a noção de cultura do medo em sua complexidade, para além das condutas conscientes de mudanças de projetos e ações motivadas pela insegurança num campo de possibilidades de vitimização, posto que o método hermenêutico nos permite decifrar os comportamentos simbólicos do homem, "o trabalho da tomada de consciência" (Ricoeur, 1988:4), que nos aproxima do propósito de elucidar "a dinâmica entre memória individual e coletiva"19 que situa as feições do medo nas múltiplas formas de os velhos habitantes interpretarem suas trajetórias vividas, construindo a partir desta 'referência' - o valor medo - a imagem que compartilham do viver na cidade.

Trata-se aqui de se conceituar o medo como valor. ${ }^{20}$ Toma-se a noção de medo como contendo qualidades simbólicas, um 'valor' que funda a oposição hierárquica, segundo Louis Dumont, em nome do qual se realiza o processo de articulação das idéias relacionais que amalgama a idéia de cultura como sistema simbólico e de sociedade como atualização de uma nova ordem social. Nesse sistema, a apreensão e a interpretação que os sujeitos fazem da realidade vivida são a abstração ou a classificação de uma ordem simbólica do mundo, mas também construção de uma inserção social na qual se devem deter os diferentes níveis de interação cultural no seio da sociedade dominante. Isso implica dizer que essa inserção encontra-se colada a 'situações' ${ }^{21}$ que combinam os valores e dão sentido às práticas sociais, imprimindo lógica e sentido à vida.

Dimensiona-se, assim, com base numa situação de crise social associada aos sentimentos de medo expressos no viver no contexto contemporâneo de violência urbana, a reflexão sobre a construção do individualismo no processo sócio-histórico moderno. O desejo idealizado de igualdade e emancipação do indivíduo moderno produz, em contraposição, o 'contágio da violência', o enfraquecimento da livre conduta e a impotência da produção de interações sociais que potencializem harmoniosamente a integridade moral e física de homens e mulheres no espaço público e privado, encerrando em seu âmbito o descompasso da ambiência humana perturbada e temerosa em seus atos recíprocos, cada vez mais fragmentados no enclausuramento do homem em si mesmo.

Trata-se de uma cultura do medo, como transparece na narrativa de D. Crista, apegada às suas reminiscências marcadas por uma nostalgia de um tempo embalado pelo sentimento de segurança, cotejado com seus temores atuais dos perigos impostos por uma violência urbana. $\mathrm{O}$ recolhimento doméstico pelo medo que se antecipa à ameaça de um perigo potencial diante da vulnerabilidade cotidiana impõe, de forma progressiva, não mais um individualismo-no-mundo, como apregoava Louis Dumont (1985), mas um individualismo-recolhido e com medo-do-mundo, preso à suposta segurança do seu lar.

O sentimento de insegurança atua sobre as formas de sociabilidade cotidianas etnografadas - relações familiares, vizinhança, trabalho, parceiros, redes associativas formais (clubes) e informais (footing), redes de amigos, lazer ou deslocamentos solitários e/ou utilitários etc. Assim, em torno da inquietude e do sentimento de vulnerabilidade em face da possível experiência de vitimização, a simples preocupação se transforma de 
imediato em medo pessoal (Roché, 1993:67), motivando não só mudanças de atitudes nas formas de as pessoas viverem e interagirem no mundo urbano contemporâneo, mas igualmente na forma de atribuírem sentido à vida e representarem seu entendimento do mundo. Trata-se da ameaça da ruptura ética que aponta para um universalismo da boa vontade, do respeito de si e da estima de si, em que o si "não é o eu. Trata-se, antes, de isolar o momento de universalidade que, na qualidade de ambição ou de pretensão (...), marca a experimentação pela norma do desejo de viver bem” (Ricoeur, 1991:238-239).

Segundo Soares, "mais do que um problema tópico específico, a violência se converteu numa linguagem compartilhada, a partir da qual (...) temos pensado os limites da sociabilidade, a sua crise e suas possibilidades" (Soares, 1995:1). O medo e a insegurança são, então, determinantes da forma de socialização cada vez mais presentes no convívio urbano, uma linguagem compartilhada de modo cada vez mais coletivo.

Esse processo está associado à tendência de qualificar todos os fenômenos que tratam a violência como um mesmo e único processo, cuja matriz, simbolicamente compartilhada, seria a decadência da cidade, a degradação dos valores éticos, que geraria a crise da civilização urbana. É essa tendência a homogeneizar as observações relativas a fenômenos associados à violência uma crise que Soares (1995:4) define por cultura do medo.

O sentimento de insegurança é mordaz, solapa a sociabilidade e as experiências públicas. A crise aparece mais aguda pela emergência da cultura do medo de ser vítima da violência, justamente na contramão da ideologia da emancipação das vigas sólidas da disciplina moral e da conduta econômica que erigiram a família nuclear nos dois últimos séculos de industrialização e urbanização. O paradoxo está entre a atitude de temer o usufruto dos direitos à liberdade de ir e vir e a de trilhar "um caminho de mudanças sociais concernentes a um campo social mais amplo do que aquele de sua própria família" (Lins de Barros, 1987:11), em que a própria diferença atribuída tradicionalmente aos papéis masculinos e femininos é questionada e ressemantizada, subvertendo estruturas disciplinares no seio da instituição familiar, que se emancipa das amarras da pudicícia vitoriana, em que a personalidade individuada ensaia determinar os destinos da cultura.

A violência desenfreada que indigna e atemoriza a todos parece trair os atores da história que levou à libertação - em relação a ordens e proibições sociomorais, a medos e opressões ligados à ordem tradicional, inculcados durante tantos séculos - e à superação de traumas morais, sentimentos de vergonha e constrangimentos associados a atos afetivos, possibilitando ações de ser-no-mundo que compõem novas formas de relacionamento familiar, liberadas dos controles morais. Os constrangimentos sociais mostraram-se bastante presentes nas narrativas, que relacionam as experiências pessoais e familiares à modernização da sociedade, às transformações dos valores morais e modelos de conduta familiar.

Agora, as trajetórias das vidas de cada indivíduo gravitam numa ambiência de agressões crescentes que extrapolam qualquer possibilidade de previsão, obrigando-os a espreitar suas práticas sociais num quadro de probabilidades em relação à violência urbana que empresta a imagem de uma sujeição a formas individualizadas de vitimização. 
Hoje, caminhar, passar, viver, pertencer, ocupar são verbos condicionados pela imagem que as pessoas interiorizam e representam sobre os espaços urbanos de maior ou menor segurança. Paliativos de toda ordem são levados em conta, cuidado com os horários sobretudo noturnos: segura-se o carro, a casa, vigia-se o bairro etc. De fato, a busca por maior segurança é uma empreitada sem fim.

Há, no contexto desses discursos, uma construção social do medo. O medo do atentado ao patrimônio e à integridade física e o medo da morte por violência revelados pelos entrevistados são sintetizados no temor à vitimização pelo crime, que tem como reação paliativa uma regulação de condutas, na qual se interioriza a hostilidade do viver urbano, alienando os depoentes de dinâmicas do mundo social. O receio resulta de um processo de contato agressivo com o outro que desestimula o indivíduo no que lhe é constitutivo: as interações que o constroem como sujeito social. Reféns do estranhamento, indivíduos em suas redes de pertencimento designam como perigosos trajetos, territorialidades, situações, horários e indivíduos que, potencialmente estranhos, ameaçam a ordem social. A desconfiança do outro mergulha-os no sentimento de esvaziamento dos sentidos coletivos, fortalecendo ainda mais as bases de um ethos social hiperindividualista.

\section{Da Arte de Viver o Cotidiano Inseguro}

Diante desse estado de crise e ameaça da ordem coletiva, moradores, habitantes, cidadãos se vêem constrangidos a buscar estratégias e formas de viver enfrentamentos, táticas (De Certeau, 1994) para reagir à crise e à violência que os anestesiam. Respostas práticas e simbólicas para garantir a integridade humana e sociabilidades que expressam um novo estilo de vida, reconfigurando o imaginário social. $\mathrm{O}$ que torna possível, entre outras, esta leitura da arte de viver o cotidiano com base nas práticas que vão estetizando novas formas de viver e estilizando as interações sociais cotidianas propulsoras de expressões múltiplas de repensar e 're-agir' na cidade dramatizada pela estética do medo, nas condutas de prevenção e de projeção de uma rotina segura, percursos e situações planejadas, trajetórias e interações comedidas, implicando uma 'estética de existência', delineada pela violência urbana como um constrangimento social externo.

No ato de narrar suas rememorações configurando o mapa dos medos, os velhos habitantes de Porto Alegre situam suas experiências com o mundo por meio desse sentimento ou de sua superação, na representação, seja dos aspectos positivos, seja dos negativos, conforme situações vividas e contextualizadas etnograficamente.

A análise, nesta instância, consiste em relacionar as formas com que experimentam as reconfigurações do envelhecimento com base em múltiplas vivências que vitalizam esse momento da vida às vicissitudes figuradas por uma violência urbana que estetiza os estilos de viver urbano.

Trata-se de dar conta das formas de reinventar o cotidiano. Esse desafio é apontado nos relatos que sinalizam a emergência progressiva de uma massa de indiví- 
duos idosos (como assinalam as estatísticas sobre os ganhos tecnológicos e científicos, e a medicina gerontológica, por exemplo, nesta passagem de século). As novas imagens construídas sobre o ser velho, ao contrário da idéia do idoso que aparece no discurso gerontológico, multifacetam o desempenho de papéis previstos socialmente para eles. O próprio convívio familiar se desamarra de antigos preceitos para ser visto em novas perspectivas.

As experiências são múltiplas tanto quanto o são os indivíduos singulares, mas o exercício dessas novas interpretações da realidade acaba por mapear um estilo de viver o drama do envelhecer sob novas figurações que emancipam os atores e possibilitam a negociação possível, seja de suas autonomias, seja de seus pertencimentos coletivos. Esse movimento não é demonstrativo de uma luta contra a família ou da 'crise familiar' que instituições morais buscam caracterizar, nem se revela uma luta contra as desigualdades de gênero (proposta do movimento feminista, por exemplo), bem como não se reduz a ações e práticas que celebram o envelhecimento, como os "programas para a terceira idade ou os grupos de convivência de idosos", que têm "na mídia o palco central para a criação e divulgação das novas imagens" (Debert, 1999:209).

Nosso propósito é acionar esse campo interpretativo das múltiplas experiências de envelhecer que não apenas elucidam um projeto reflexivo do eu, mas valorizam a experiência e o saber de ser um sujeito com memória do seu eu, do seu grupo, de sua cidade, onde ele próprio é sujeito configurador de uma história coletiva. Os acontecimentos cotidianos não lhe parecem, assim, alheios a seus jogos de memória e fluxos de vida. Não se trata também de rejuvenescer o lugar (o país, a cidade, sua família) com base no cultivo da memória do social, que reduziria a qualidade narrativa ao lugar de velho habitante, ao santuário da preservação e da conservação de referências identitárias emblemáticas.

A adesão à estética do medo não impede o aproveitamento de formas de sociabilidade privilegiadas para a valorização pessoal e afetiva, como relata Sr. Mauro, que cultiva grupos de amigos em reuniões semanais, assim como motiva a vivência de práticas religiosas já tradicionais na cultura brasileira, como o catolicismo, ou a adesão a formas mais recentes no ethos brasileiro, como a opção espiritual de D. Raquel.

Ser porto-alegrense, para o velho habitante narrador, não é afundar-se nos traços de um passado perdido. Mas é como velho habitante que ele pode delinear os múltiplos movimentos que o sujeitam a conflitos e tensões pessoais/coletivos, internos/externos, singulares/complexos, em que negocia incessantemente uma identidade familiar e social, individual e coletiva.

Ser velho é viver um conflito de identidade, e ser velho habitante de Porto Alegre é igualmente viver as tensões identitárias que a cidade amalgama. Conflitos que descompassam a rítmica das trajetórias de vida e do trajeto urbano (história da cidade), mas não matam a inventividade do viver nesse ethos. É com sua identidade de velhos habitantes que podem então narrar sua cidade, enfim, trabalhar a memória tecendo as 'reminiscências' que 're-situam' as experiências orientadas pelo sentimento do medo como algo vivido, temporalizando a vida por essa 'identidade-valor', em que se percebem como sujeitos transformados na predominância de outros valores significativos no passado. Mas, tocados pelas circunstâncias, nos jogos da memória, os velhos 
habitantes vão singularizando essas mobilidades desconcertantes impressas por condições externas e acabam por conferir ao próprio ato de memorar uma poética temporal na vigília pelo aprendizado de reinventar a vida por reordenações dos sentidos fragmentados. Ou, como diz De Certeau, "na arte de contar as maneiras de fazer, estas se exercem por si mesmas" (De Certeau, 1994:166).

Compartilhar da cultura do medo que se impõe pela linguagem ordinária, e que naturaliza seu conteúdo, acaba por permitir o conhecimento desse processo e ultrapassálo, não na negação, mas na adesão a essa realidade, no reconhecimento da existência do conflito na dramatização das relações sociais. Compreender nossa relação com a cultura do medo seria, de certa forma, conhecer nossa tática de pensar a morte para desejar a vida. Não se trata de criar a expectativa de prorrogar a morte fisiológica, mas de ultrapassar as rupturas trágicas, que ameaçam de esquecimento as referências de uma duração da identidade do grupo.

Se a violência nos situa no drama trágico da vida pela sua dinâmica cíclica como determinante simbólico, a cultura do medo como crise nos situa num jogo interativo, dialógico e reflexivo que acaba por permitir, em alguma dimensão, o conhecimento do 'si-mesmo'. Uma circunstância que nos faz ver a cidade inventada por nós mesmos, uma trajetória de vida traçada pelo nosso desejo e por temores constituídos por nossos ressentimentos.

As narrativas que delineiam fragmentos de trajetórias são apreendidas como prospecção e projeção das possibilidades de realização de um projeto de humanidade. Se o aceleramento dos acontecimentos urbanos entrelaça a violência que escapa à legibilidade, o medo da vitimização nos ameaça como condição de possibilidade de um desconhecimento do outro e de esquecimento das práticas conciliadoras de redes de sentido.

\section{Conclusĩo}

Os conflitos, as crises, as tensões do mundo moderno têm sido historicamente vinculados ao fenômeno urbano, contexto que implica compreender a vida e as interações sociais diferenciadas em graus de concretude e vividez.

Diante de um aumento desmesurado da violência nas grandes cidades, a questão da sobrevivência assumiu aspectos especialmente dramáticos, como sugere Gilberto Velho: "Pode-se especular que essas seriam variáveis importantes para compreender uma espécie de individualismo agonístico que se tornou cada vez mais freqüente nas camadas médias brasileiras" (Velho, 1987:4).

Pensar a condição de viver na cidade, hoje, implica pensar sobre as formas culturais e simbólicas dinamizadas igualmente por sentimentos de medo, insegurança, ansiedade e solidão, mapeando a cidade como um grande repositório de vítimas de um contexto urbano ameaçado por crises, violência, fragmentações, esquecimentos etc. $\mathrm{O}$ sentimento de insegurança não encontra eco nas eventuais providências político-administrativas estatais, na maioria das vezes insuficientes.

Diante da ineficiência do aparelho estatal para limitar essa onda de ameaças (uma vez que em grande parte o próprio aparelho e sistema estatal é corrompido: polícia, 
políticos etc.), temerosos ou não, os habitantes tomam precauções, atitudes, adotam comportamentos que atuam sobre práticas e sociabilidades cotidianas.

O cenário da cidade se confirma, assim, como topos de uma multiplicidade de acontecimentos individuais e coletivos que denotam experiências vividas carregadas de sentimento de insegurança. Este sentimento é, sem dúvida, algo que envolve uma série de aspectos psicológicos e culturais dos indivíduos, suas emoções, suas reflexões e seus comportamentos.

Tendo os indivíduos sido vítimas de situações de violência urbana ou simplesmente bombardeados pela mídia, sua reclusão passa a ser uma atitude recorrente; desconfiam de suas próprias certezas sobre a previsibilidade de sua 'sorte' em seus movimentos interativos em redes diversas no mundo urbano. A previsibilidade escapa 'das suas mãos', ou do seu pensamento, para ser substituída pelo temor advindo da imprevisibilidade imposta pela violência urbana.

O medo estruturante é o de sair em espaço público, sobretudo em determinado horário. A insegurança concerne a todos, mas ao idoso esta condição parece mais perversa, principalmente no final do seu ciclo de vida, em geral mais solitário, quando tem de contar com os imponderáveis do corpo envelhecido. Os idosos de segmentos médios que optam pela autonomia residencial aderem aos 'conselhos' de prevenção que configuram os "medos domésticos" (Roché, 1993), como o de se trancar em casa "a sete chaves", o não atender à porta, aumentar a proteção do domicílio. A vida intramuros não é um desejo, mas uma prevenção para evitar a vitimização. Os recursos acessíveis aos pertencentes ao segmentos da classe média são investidos na segurança material; a grade e o alambrado se destacam na arte da proteção.

A vida social no mundo público não se rompe, pois o idoso nutre-se nele como ser social, mas esta interação é permeada pelo receio, medo do estranho, medo do assalto, medo dos muitos acidentes de percurso e das armadilhas a que está sujeito na condição cotidiana, numa espécie de agorafobia. Ambas as formas de configurar as inquietudes são correlatas com a expressão de um medo que se afirma na subjetividade: "eu estou inseguro" (Roché, 1993:150). Essas formas de expressão das preocupações que habitam os corações e as mentes dos citadinos se colocam como uma discursividade (um texto) do desejo coletivo da reconstrução de uma ordem perdida, de uma normatividade desfeita, de uma sociedade que lhes parece cada vez mais estranha e incivilizada, buscando incessantemente, no contexto da imponderabilidade, os sentidos de seguir.

De modo geral, serão as vozes citadinas dos segmentos médios, movidos pela lógica do auto-interesse, que aclamarão a incivilidade que retrata a violência urbana, a qual ressoa em suas avaliações sobre a perda dos valores morais, o esvaziamento de sentido ético, a desordem e o desencantamento das emoções humanas, a banalização do horror, a subversão dos direitos, a saturação (ou os excessos) dos modelos de gestão política da ordem social, a guerra civil.

Os constrangimentos impostos pela violência, dirão os velhos habitantes de Porto Alegre, tensionam os valores modernos na perda de referências humanitárias, a reciprocidade, a solidariedade encapsulada num tempo alhures, atribuindo às estrutu- 
ras de poder político-urbanas a tarefa de salvaguarda do mundo objetivado da lógica racionalista traduzida em atos e normas de coibição da criminalidade.

Nas experiências de vida dos entrevistados, nesta cidade, o sentimento de medo é constitutivo de uma crise que desancora as probabilidades de suas projeções de vida. A clivagem de suas vontades e escolhas não pode mais seguir apenas um traçado livre da ideologia individualista, mas precisa conformar suas volições ao mapa do medo. A 'crise dos tempos', presente para a população etnografada, é a ruptura do trajeto de identificação do indivíduo psicológico como o sujeito da consciência, da vontade e da autonomia, sobretudo ao condicionar o futuro dos netos a um mundo cotidiano que não garante mais uma previsibilidade da vida, de reconhecimento do outro na imagem ideal do prometeico trabalhador honesto.

Nesse contexto de cultura do medo, o citadino tende a aguardar macrorreestruturações com eficácia para a garantia de uma qualidade de vida humana, cultivando em suas impressões do viver urbano as crises dos tempos gestadas nos discursos midiáticos, que acabam por imprimir códigos de interpretação da realidade.

Mas, na incessante arte de narrar sua cidade, os velhos habitantes acabam por transmitir formas de ultrapassar a passividade de nossos sentimentos urbanos de desencantamento. É nesse sentido que buscou-se a narrativa de 'durar' na cidade em que viveram, esse trabalho árduo de não deixar cair no esquecimento as 'artes de fazer' o social, dado que o trabalho da memória, de lembrar o que não esquecemos, tem essa força de reconstruir as razões afetivas para continuar.

\section{NOTAS}

1 Artigo relacionado à pesquisa Estudo Antropológico de Itinerários Urbanos, Memória Coletiva e Formas de Sociabilidade no Mundo Urbano Contemporâneo, desenvolvida em Porto Alegre sob minha coordenação e da antropóloga Ana Luiza Carvalho da Rocha, com auxílio do CNPq, no Banco de Imagens e Efeitos Visuais, PPGAS/UFRGS, iniciada em 1997. De 33 entrevistas realizadas até 1999 (22 gravadas em fitas cassete e 11 em vídeo digital, transcritas), 18 foram com pessoas de 60 a 87 anos; nove com pessoas de 40 a 60 anos; seis com pessoas de 20 a 40 anos. Os entrevistados pertencem, na maioria, a segmentos médios, mas também desenvolvemos pesquisa com uma população de baixa renda, moradores de vilas na periferia. Neste artigo, analisam-se as entrevistas com pessoas de mais de 60 anos.

Agradeço a Maria Cecília de Souza Minayo e Carlos E. A. Coimbra Jr. as sugestões elaboradas por ocasião da oficina de trabalho Antropologia, Saúde e Envelhecimento (Rio de Janeiro, ago.2000). Agradeço igualmente a Clarissa Eckert Baeta Neves e Ana Luiza Carvalho da Rocha, pela leitura atenciosa e pela proveitosa discussão do texto.

2 Nos termos de Soares, "uma certa estrutura simbólica de articulação entre representações” (Soares et al., 1996:259). 
3 Citamos como exemplo a reportagem 'A centrífuga do medo na cidade', na revista Veja. Segundo o texto de Dorrit Harazim, "como um véu que impede a percepção dos verdadeiros problemas, a paranóia social do rico confunde medo com pobre". Veja, 23/11/1994, p. 78.

4 Porto Alegre, IBGE, 1996: população - 1.286.251 habitantes; expectativa de vida 70,3 anos; mortalidade infantil - 18 por mil habitantes; população alfabetizada $91 \%$.

5 'Vítimas da insegurança: as seqüelas da violência', Jornal Zero Hora, Porto Alegre, 23/7/2000, p. 44. Os gaúchos, segundo esta reportagem, sofreram 48.710 lesões corporais no primeiro semestre de 1999, enquanto no Rio de Janeiro foram registrados 325 casos a menos. Entram nessa contabilidade agressões como socos, facadas, garrafadas e tiros. Reportagem de Patrícia Specht.

6 "O chamado footing na Rua da Praia era antigo hábito entre rapazes e moças, que perdurou em Porto Alegre até os anos 60. Consistia em passeios, a determinadas horas, sem maiores compromissos, a não ser tentar algum namoro, ver o movimento ou por simples passatempo." Zero Hora, Porto Alegre, 23/10/2000. Almanaque Gaúcho - Túnel do tempo, Antônio Goulart, p. 54.

7 “As pesquisas sobre grupos de idade mostram, por um lado, que a geração, mais do que a idade cronológica, é a forma privilegiada de os atores darem conta de suas experiências extrafamiliares; por outro lado, indicam que mudanças na experiência coletiva de determinados grupos não são apenas causadas pelas mudanças sociais de ordem estrutural, mas que estes grupos são extremamente ativos no direcionamento das mudanças de comportamento, na produção de uma memória coletiva e na construção de uma tradição. A idéia de geração, apesar das várias conotações que assume, teria assim uma efetividade que ultrapassa o nível das relações na família, direcionando transformações que a esfera da política tem que incorporar." (Debert, 1999:52-53)

8 Seguimos os preceitos de Pierre Bourdieu, para quem a noção de classe social ou 'segmentos médios' deve ser apreendida com base tanto na posição e situação na estrutura social quanto nos bens simbólicos e no capital cultural referentes às relações entre as classes, uma vez que se relacionam ao mundo representacional que os atores conferem a suas posições de pertencimento (Bourdieu, 1974).

9 O antropólogo Gilberto Velho, em sua obra A Utopia Urbana (1989), sobre segmentos médios cariocas, faz uso do conceito de white-collars da obra de Wright Mills, pois é neste mundo "que se deve buscar grande parte do que é característico da vida do século XX” (Mills, 1975:120).

10 Mike Featherstone (apud Debert, 1994) analisa a forma como especialistas da psicologia do desenvolvimento relacionam o curso da vida com fases cronológicas bem demarcadas. Tem-se o que chamamos de colonização das idades.

11 Guita Debert (1994) chama a atenção para o fato de que o processo de individualização, próprio da modernidade, teve na institucionalização do curso de vida uma de suas dimensões fundamentais. 
12 Rua circundada pelo maior parque da cidade (Parque Redenção), pelo Colégio Militar e por edifícios residenciais.

13 Aspecto analisado por Myriam Moraes Lins de Barros em seu artigo 'Testemunho de vida: um estudo antropológico de mulheres na velhice', constatando que a perda de consciência e a velhice-doença eram os maiores temores, ligados à ruptura do projeto de viver a velhice (Lins de Barros, 1995:165).

14 “Os saberes 'psis' afirmam-se como importante foco de produção social de representações sobre o indivíduo moderno" (Salem, 1992:69).

15 Ambos são filhos de Ares, o deus da guerra, e acompanham seu pai por onde houver conflito e sangue.

16 Concepção de William I. Thomas, conforme Schutz in Wagner (1979:26).

17 "O lado individual (nos projetos de vida) é o das emoções. As minhas emoções estão ligadas, são matéria-prima e, de certa forma, constituem o projeto. Há sentimentos e emoção valorizados, tolerados ou condenados dentro de um grupo, de uma sociedade. Há, portanto, maiores ou menores possibilidades de viabilizá-los, efetivá-los" (Lins de Barros, 1995:155).

18 Como sugerem os trabalhos etnográficos em segmentos médios brasileiros de Velho (1979), Lins de Barros (1995) e Salem (1980).

19 O artigo 'O passado no presente: aos 70 falando do Rio de Janeiro' serviu, aqui, como base para nossas reflexões (Lins de Barros 1995: 92).

20 Segundo Dumont (1985), o 'valor' designa algo diferente do 'ser', algo que, distinto da verdade científica, que é universal, varia muito com o meio social e até no seio de uma sociedade dada, não só com as classes sociais, mas, também, com diferentes setores de atividade e experiência.

21 Propriedades de situação, conforme Evans-Pritchard, (1978).

\section{ReFerêNCIaS BibLiográficas}

ARENDT, H. Sobre a Violência. Rio de Janeiro: Relume-Dumará, 1994.

BACHELARD, G. La Dialectique de la Durée. Paris: Quadrige, PUF, 1989.

BENJAMIN, W. Crítica da violência - Crítica do poder. In: BENJAMIN, W. Documentos de Cultura - Documentos de Barbárie: escritos escolhidos. São Paulo: Cultrix, EDU São Paulo, 1986.

BENJAMIN, W. Magia e Técnica, Arte e Política: ensaios sobre literatura e história da cultura. São Paulo: Brasiliense, 1993.

BENJAMIN, W. Charles Baudelaire: um lírico no auge do capitalismo. São Paulo: Brasiliense, 1995.

BERMAN, M. Tudo que é Sólido Desmancha no Ar: a aventura da modernidade. São Paulo: Cia. das Letras, 1987. 
BOSI, E. Memória e Sociedade: lembranças de velhos. São Paulo: Queiroz, Edusp, 1987.

BOTT, E. Família e Rede Social. Rio de Janeiro: Francisco Alves, 1976.

BOURDIEU, P. A Economia das Trocas Simbólicas. São Paulo: Perspectiva, 1974.

CANEVACCI, M. A Cidade Polifônica: ensaio sobre a antropologia da comunicação urbana. São Paulo: Studio Nobel, 1993.

D’ÁVILA, N. L. M. Na Trajetória da Modernidade, as Camadas Médias Porto-alegrenses frente à Modernização na Década de 50, 1996. Dissertação de Mestrado, Porto Alegre: Programa de Pós-Graduação em História, Universidade Federal do Rio Grande do Sul.

DA MATTA, R. A Casa \& A Rua: espaço, cidadania, mulher e morte no Brasil. São Paulo: Brasiliense, 1985.

DEBERT, G. G. (Org.) Antropologia e Velhice. Campinas: IFCH/Unicamp, 1994. (Textos didáticos, 13).

DEBERT, G. G. A Reinvenção da Velhice. São Paulo: Edusp, Fapesp, 1999.

DE CERTEAU, M. A Invenção do Cotidiano: artes de fazer. Petrópolis: Vozes, 1994.

DELUMEAU, J. História do Medo no Ocidente: 1300-1800. São Paulo: Companhia das Letras, 1989.

DUVIGNAUD, J. Festas e Civilizações. Fortaleza: EUFCeará, Tempo Brasileiro, 1983.

DIAS DUARTE, L. F. Da Vida Nervosa nas Classes Trabalhadoras Urbanas. Rio de Janeiro: Zahar, CNPq, 1986.

DUMONT, L. O Individualismo: uma perspectiva antropológica da ideologia moderna. Rio de Janeiro: Rocco, 1985.

ELIAS, N. A Sociedade dos Indivíduos. Rio de Janeiro: Jorge Zahar, 1994.

EVANS-PRITCHARD, E. E. Os Nuer. São Paulo: Perspectiva, 1978.

FOUCAULT, M. Microfísica do Poder. Rio de Janeiro: Graal, 1979.

FOUCAULT, M. Vigiar e Punir. Petrópolis: Vozes, 1988.

GANDILLAC, M. de. Gêneses da Modernidade. Rio de Janeiro: Editora 34, 1995.

GEERTZ, C. A Interpretação das Culturas. Rio de Janeiro: Zahar, 1978.

GIDDENS, A. As Conseqüências da Modernidade. São Paulo: Unesp, 1991.

GOFFMAN, E. La Mise-en-Scène de la Vie Quotidienne. Paris: De Minuit, 1973.

GRAFMEYER, Y. \& JOSEPH, I. L'Ecole de Chicago: naissance de l'écologie urbaine. Paris: Aubier Montaigne, 1984.

HALBWACHS, M. La Mémoire Collective. Paris: PUF, 1968.

HARVEY, D. Condição Pós-Moderna. São Paulo: Loyola, 1996.

ISRAEL, J. Simmel et quelques problèmes fondamentaux de la connaissance. Revue Société. Georg Simmel. Paris: Dunod, 1992. 
JACOBS, J. Morte e Vida de Grandes Cidades. São Paulo: Martins Fontes, 2000.

LASCH, C. The Culture of Narcisism: american life in the age of diminishing expectations. Nova Iorque: Mouton, 1978.

LINS DE BARROS, M. O passado no presente: aos 70 falando do Rio de Janeiro. Cadernos de Antropologia e Imagem [A Cidade em Imagens], 4. Rio de Janeiro: Uerj, NAI, 1995.

LINS DE BARROS, M. Autoridade \& Afeto. Rio de Janeiro: Jorge Zahar, 1987.

MAUSS, M. Sociologia e Antropologia. São Paulo: EPU/Edusp, 1974.

MILLS, C. W. A Imaginação Sociológica. Rio de Janeiro: Zahar, 1975.

PORTO ALEGRE. Jornal Zero Hora. 23/7/2000.

PORTO ALEGRE. Jornal Zero Hora. 20/8/2000.

PORTO ALEGRE. Jornal Zero Hora. 23/10/2000.

PORTO ALEGRE. Jornal Zero Hora. 31/10/2000.

RICOEUR, P. Interpretação e Ideologias. Rio de Janeiro: Francisco Alves, 1988.

RICOEUR, P. O Si-Mesmo como um Outro. Campinas: Papirus, 1991.

RICOEUR, P. Tempo e Narrativa. Tomos I e II. Campinas: Papirus, 1994.

ROCHÉ, S. Le Sentiment d'Insécurité. Paris: PUF, 1993.

ROVINSKI, S. L. R. A Violência na Vitimização Criminal: vivências em situações de assalto, 1993. Dissertação de Mestrado. Porto Alegre: Instituto de Psicologia, Pontifícia Universidade Católica do Rio Grande do Sul.

SALEM, T. Um Estudo de Papéis e Conflitos Familiares. Petrópolis: Vozes, 1980.

SALEM, T. A “despossessão subjetiva”: dos paradoxos do individualismo. Revista Brasileira de Ciências Sociais, 18:62-77, 1992.

SCHUTZ, A. Textos Escolhidos de Alfred Schutz. (Wagner, H. R., org.). Rio de Janeiro: Zahar, 1979.

SENNET, R. O Declínio do Homem Público. São Paulo: Cia. das Letras, 1988.

SENNETT, R. Les Tyrannies de l'Intimité. Paris: Seuil, 1979.

SIMMEL, J. Cultura Femenina y Otros Ensayos. Madri: Revista de Occidente, 1934.

SOARES, L. E. Homicídios dolosos praticados contra menores no Estado do Rio de Janeiro. Relatório de pesquisa desenvolvido como parte do plano de trabalho do projeto Se Essa Rua Fosse Minha. Rio de Janeiro: Fase, Ibase, Idac, Iser, 1991.

SOARES, L. E. Violência e cultura do medo no Rio de Janeiro. Palestra proferida no Programa de Pós-Graduação em Antropologia Social. Porto Alegre: UFRGS, mar.1995. (Mimeo.)

SOARES, L. E. et al. Violência e Política no Rio de Janeiro. Rio de Janeiro: Relume-Dumará, Iser, 1996.

SOREL, G. Reflexões sobre a Violência. Petrópolis: Vozes, 1993. 
TIRELLI, C. Cartografia Social da Violência: estudo sobre a criminalidade na Região Metropolitana de Porto Alegre - 1988 a 1995, 1996. Dissertação de Mestrado, Porto Alegre: PPGS da Universidade Federal do Rio Grande do Sul.

TURNER, V. Social dramas and ritual metaphors. In: TURNER, V. (Org.) Dramas Fields and Metaphors: symbolic action in Human Society. Itacha: Cornell University Press, 1974.

VEJA. 23/11/1994.

VELHO, G. \& FIGUEIRA, S. (Coords.) Família, Psicologia e Sociedade. Rio de Janeiro: Campus, 1981.

VELHO, G. O cotidiano da violência: identidade e sobrevivência. Boletim do Museu Nacional: nova série. 30/4/1987. (Antropologia, 56).

VELHO, G. Individualismo e Cultura: notas para uma antropologia da sociedade contemporânea. Rio de Janeiro: Zahar, 1981.

VELHO, G. Subjetividade e Sociedade. Rio de Janeiro: Zahar, 1986.

VELHO, O. (Org.) O Fenômeno Urbano. Rio de Janeiro: Zahar, 1979.

VELHO, G. A utopia urbana. Rio de Janeiro: Zahar, 1989.

WEBER, M. La Ville. Paris: Aubier Montaigne, 1982.

ZALUAR, A. Condomínio do Diabo. Rio de Janeiro: Revan, UFRJ, 1994. 


\title{
Envelhecimento e Juventude no Japão e no Brasil: idosos, jovens e a problematização da saúde reprodutiva
}

\author{
Russel Parry Scott
}

Os japoneses e os brasileiros compartilham uma grande semelhança: vivem em países em processo de envelhecimento populacional que têm grandes preocupações com o que está acontecendo com os seus jovens. É essa relação entre envelhecimento e juventude que abordo aqui. Um dos eixos interpretativos fundamentais desta leitura do fenômeno se localiza no controle social da saúde reprodutiva, que se torna alvo de preocupações morais e materiais, como será evidenciado em cada um dos itens diferentes abordados.

A comparação de dois países com um contingente populacional semelhante (o Japão, com 126 milhões, tem em torno de 3/4 do total da população do Brasil - 166 milhões de habitantes), com extensões territoriais muito diferentes (o Brasil é 22 vezes mais extenso), com histórias e culturas extraordinariamente díspares, e, sobretudo, ocupando locais diferentes na escala de desenvolvimento humano e qualidade de vida divulgada em abril de 2000 pela Organização Mundial da Saúde (o Japão ocupa o primeiro lugar, o Brasil o 125\%), oferece uma oportunidade para compreender os efeitos da interação entre cultura, sociedade e processos demográficos. Em ambos os casos, evidencia-se que o envelhecimento populacional é um processo social cujas conseqüências não se restringem ao contingente populacional mais idoso, e sim permeiam todas as gerações e, ainda mais, todos os setores da sociedade.

Em primeiro lugar, descrevo comparativamente como Japão e Brasil estão vivendo o processo de envelhecimento populacional por meio da apresentação da distribuição etária das suas populações e suas transformações recentes. Assim, será possível identificar, parcialmente, o que significa 'muitos idosos' para os dois países, e como isso redunda na visibilidade dos jovens. Em segundo, identifico algumas maneiras pelas quais se evidencia a problematização diferenciada de jovens brasileiros e japoneses pelas suas próprias sociedades, e a relação de tal problematização com a presença de uma população cada vez mais idosa. Em terceiro, enfoco diferenças no mercado de trabalho e na previdência entre os países como demonstração das implicações de qualidades de vida bem díspares, bem como para entender como se engendram preocupações diferentes sobre os jovens de acordo com a constituição destas questões. Em quar- 
to lugar, descrevo como ocorreram as quedas de fecundidade nos dois países, demonstrando diferenças culturais, sociais e históricas no desenvolvimento da saúde reprodutiva que precisam ser compreendidas para realizar uma comparação entre os processos. Em quinto, discuto as transformações nas relações familiares e nas relações entre gerações e gênero como o pano de fundo fundamental para a compreensão da perspectiva de relações intergeracionais e as suas implicações para a reprodução social e a continuidade ou melhora da qualidade de vida das populações jovens e idosas dos dois países.

\section{Muitos Idosos?}

O Japão é o país com a maior expectativa de vida ao nascer - 83,82 anos para mulheres e 77,19 anos para homens (JOICFP, 1999:21) -, a qual aumentou em quase dez anos desde 1970. Os idosos têm o crescimento relativo mais alto entre todas as faixas etárias do país. Evidentemente, essa longevidade faz com que ele abrigue uma das maiores proporções de população acima de 65 anos - 15,7\% em 1997 -, como se vê no Gráfico 1 (JOICFP, 1999:10). Como a queda de fecundidade ocorreu há muitos anos no Japão, o país se encontra numa situação em que os adultos entre 40 e 55 anos constituem as faixas etárias proporcionalmente maiores. Ao mesmo tempo, as faixas mais jovens (de 0 a 20 anos) sofrem decréscimos sucessivos na sua participação na pirâmide populacional e esboçam uma projeção de crescimento populacional negativo no futuro imediato. Os jovens são poucos e não estão crescendo em número, e os adultos entrando para a faixa dos idosos são muitos. É essa relação entre as gerações que influencia a forma como a sociedade encara a sua população mais jovem.

Gráfico 1 - Pirâmides etárias comparadas. Japão - 1997; Brasil - 1995

$$
\text { Japão }
$$

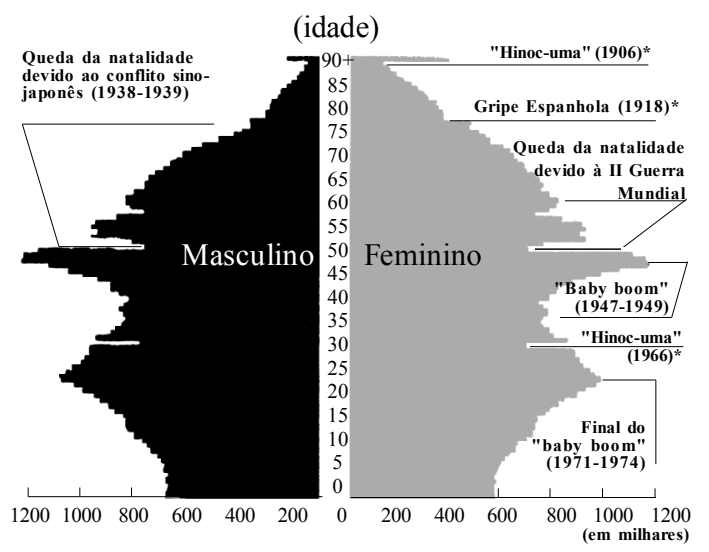

*No ano "Hinoc-uma" (ano do "cavalo de fogo", segundo o calendário chinês), o número de gravidezes era intencionalmente controlado. Há uma superstição de que as meninas nascidas nesse ano matariam seus maridos.

Fontes: JOICFP, 1999:10 e CNPD, 1998:16.
Brasil

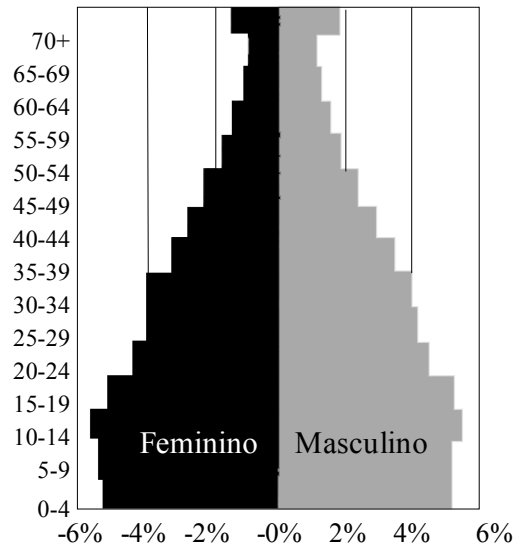


O Brasil, que há muitos anos tem se caracterizado como ‘um país jovem', não somente pela sua história mais recente, mas também pelas proporções relativamente altas de população mais jovem que constituem a sua população (ver Gráfico 2 CNPD, 1998:16), ${ }^{1}$ contém uma proporção menor de idosos na sua população total (8,6\% acima de 60 anos em 1997, e somente 5,4\% acima de 65). De 1970 a 1995, a expectativa de vida média brasileira aumentou de 63,18 para 65,86 anos para os homens e de 70,20 para 73,74 para as mulheres (CNPD, 1998:13), refletindo uma tendência freqüentemente anunciada de envelhecimento populacional, mas que ainda fica apenas como 'sombra' do processo de envelhecimento populacional no Japão, e também apresenta cifras que indicam que a longevidade brasileira está sujeita a uma qualidade de vida baixa, segundo a OMS.

O envelhecimento da população brasileira redunda numa relação diferente com as outras faixas etárias da população, quando comparado com o do Japão. Como a queda de fecundidade é recente, o Brasil apresenta uma 'onda jovem', com 30\% da sua população entre 10 e 24 anos. Dentro deste grupo, é ainda a faixa de 15 a 19 anos que detém as maiores proporções. É evidente que os idosos e os jovens são os contingentes populacionais que mais crescem no Brasil. Ou seja, os muitos idosos brasileiros continuam acompanhados por muitos jovens.

\section{Os Jovens Sĩo Problemas?}

O título deste item identifica uma parte importante de nosso enfoque. Aqui, a questão é: quais as preocupações que a sociedade manifesta sobre os jovens? Isso se reflete em conversas informais, na mídia, em estudos de opinião e na definição de estatísticas formais e políticas públicas, e não necessariamente na própria opinião dos jovens sobre si. Seria pretensioso tentar identificar toda a variedade de maneiras com que essas preocupações se manifestam, pois são tão diversas quanto as próprias sociedades em si. Então, optou-se aqui por identificar como algumas preocupações específicas sobre os jovens se associam mais proximamente aos processos demográficos intergeracionais, e como ocorrem conflitos entre os procedimentos dos jovens e as expectativas dos que pensam sobre, ou que efetivamente formulam, políticas de direcionamento da composição ideal da população nacional (em termos quantitativos e em termos morais!).

A escolha das preocupações descritas é resultado de processos de reflexão e observação muito diferentes para as duas sociedades. No caso do Japão, os dados são impressões mais ou menos dirigidas, oriundas de uma missão de estudos sobre saúde pública, saúde reprodutiva e planejamento familiar realizada durante trinta dias em novembro e dezembro de $1999 .^{2}$ No caso do Brasil, as reflexões se relacionam com um período muito maior de estudo sistemático e participação na comunidade acadêmica e política relacionada com a compreensão da família brasileira (desde o início dos anos 70), mas estão mais fortemente relacionadas com a pesquisa atual do Núcleo de Família, Gênero e Sexualidade (Fages) sobre Reprodução, Sexualidade e Programas de Saúde em 
Grupos Sociais Distintos em Pernambuco. ${ }^{3}$ Em nenhum dos dois casos, a questão de envelhecimento populacional foi adotada inicialmente como perspectiva de interpretação, tendo aparecido como uma questão cuja importância se impôs para a compreensão dos fenômenos sob investigação. Por sua vez, o comportamento reprodutivo dos jovens foi, evidentemente, um dos principais eixos comuns das duas investigações, e é por isso que ela está ressaltada aqui, tanto diretamente, na identificação de preocupações, quanto indiretamente, nas interpretações sobre fatos observados e coletados.

Os jovens preocupam os japoneses. Preocupam porque, além de serem poucos, não estão correspondendo à vontade, caracteristicamente interesseira (por sua faixa etária e pela nação), dos adultos de assegurarem um bem-estar futuro para as gerações mais velhas. Muitos dos japoneses adultos identificam a si mesmos como uma das principais causas de tal preocupação. Eles reduziram o número de filhos e agora precisam enfrentar a dificuldade destes mesmos filhos em sustentar os seus pais.

Há muitas maneiras de identificar essa preocupação. O que mais chama a atenção do observador da sociedade japonesa é a opinião, muito generalizada, de que os filhos estão sendo superprotegidos, exageradamente paparicados pelos seus próprios pais.

Numa das manifestações dessa superproteção, encontram-se os clássicos 'jovens rebeldes,' que procuram sublinhar as diferenças entre eles mesmos e seus pais. São os jovens que se apresentam como muito moderninhos, usando moda ocidental exagerada, pintando os seus cabelos e ornamentando-se de formas muito chamativas. Isso é mais evidente nas moças que usam casacos preferencialmente de pele e brancos, cabelos tingidos de branco ou ruivo, camadas grossas de maquiagem, brincos e adereços coloridos e grandes, e sapatos de plataforma cujos saltos altíssimos são a alegria dos ortopedistas do país! Essas moças, e os rapazes que as acompanham nas ruas, nas boates e nas lojas de Pachinko (salões repletos de jogos eletrônicos), aparentam afastar-se significativamente de alguns valores tradicionais nipônicos. Ao mesmo tempo que apelam para uma aparência de alta inconformidade, são os comentários que suscitam, mais do que a direção explícita da sua inconformidade, que apontam uma questão sobre a inserção da juventude na sociedade.

Muitos japoneses opinam que esse comportamento é o resultado de superproteção dos pais. Ou seja, o mimo dos pais permite que os filhos apresentem uma face pública de procura de liberdade, autonomia e independência que aparenta um afastamento dos padrões tradicionais da sociedade. Mas é um mimo sustentado por um alto padrão de consumo, característica generalizada no Japão contemporâneo. A rebeldia não atinge o consumo como componente fundamental do bem-estar. É preciso que haja pais que sustentem esses costumes. E os pais dizem que têm de ser mais tolerantes com esse comportamento porque hoje em dia cada casal só tem um ou dois filhos, e estão receosos de que os filhos se distanciem mais da família e dos pais.

Se esses jovens chamam a atenção para si mesmos, é importante reconhecer que há um contingente, ainda maior, de jovens japoneses que estão batalhando para ganhar o seu espaço na economia e na sociedade por meio da reafirmação de valores ultratradicionais de dedicação plena ao trabalho. E, de forma cada vez mais forte, pelo menos desde a Segunda Guerra Mundial, esse grupo inclui jovens de ambos os sexos, rapazes e moças. $\mathrm{O}$ trabalho feminino se tornou uma realidade muito importante na 
economia japonesa, e não há dúvidas de que isto é um fator de peso na decisão de elas (e eles) investirem esforços no sucesso nesta esfera. Em geral, isso significa adiar tanto o casamento quanto a procriação. A média de idade de casamento das japonesas tem sido de 26 anos e a dos japoneses, 28. A essa altura, tanto o homem quanto a mulher geralmente estão trabalhando e ainda preferem passar alguns anos investindo no trabalho, antes de ter filhos.

O primeiro filho tende a representar um transtorno na carreira da mãe, como ouvi muitas mães japonesas contarem. Mesmo havendo alguns apoios, governamentais e particulares, na criação desses filhos pequenos (legislação, creches, auxílio financeiro), a mulher se vê obrigada a enfrentar um período de afastamento do seu trabalho que ela mesma julga prejudicial, e na decisão sobre o nascimento de um segundo filho pesa muito a sua potencial repercussão sobre a inserção da mulher no mercado de trabalho. Não é de estranhar que a média de filhos por mulher no Japão tem estado em pleno decréscimo desde quando o mercado de trabalho se abriu mais para a sua participação e que hoje ela seja de apenas 1,4 filho, abaixo do nível de reposição da população.

Então, quando se trata da questão da saúde reprodutiva, a preocupação dos japoneses com os jovens é muito relacionada ao baixo número de filhos e à entrada tardia na reprodução efetiva devido à alta valorização, pelos jovens, do trabalho e da autonomia. Ter poucos filhos redunda em alta preocupação dos pais com o sucesso destes filhos, significando, além de superproteção (como se fosse um investimento no bem-estar dos filhos), supercobrança quanto ao sucesso deles no mundo do trabalho.

O resultado é a continuação de uma baixa fecundidade, que se torna um problema para os planejadores governamentais que trabalham com a redistribuição da renda entre gerações (sobretudo no sistema de previdência, como se verá mais adiante) e também para os próprios pais que, quando mais velhos, ficam dependentes de um único filho, e não mais de uma prole maior, que antigamente podia dividir a responsabilidade do sustento dos idosos. Algumas medidas governamentais atuais de alta cotação são as que possam promover uma ampliação da fecundidade japonesa, embora haja um ar de pessimismo sobre a sua eficiência, devido aos ganhos individuais (liberdade, autonomia, renda relativa) que a sociedade percebe na baixa fecundidade.

Para resumir, a sociedade japonesa, ao criar condições de garantir um envelhecimento saudável e trabalho bastante pleno para a sua população, olha os seus jovens na expectativa de poder contar com quem sustente tanto o país quanto os pais no futuro, e enxerga um problema de baixa fecundidade, que deseja corrigir.

No Brasil, o fato de a população estar em processo de envelhecimento também tem implicações para a maneira como a sociedade enxerga os jovens, mas o fato de o envelhecimento populacional ser um processo mais recente modifica o conteúdo das preocupações. A queda de fecundidade ocorreu mais entre as mulheres na faixa superior da idade reprodutiva, e deve-se em boa parte a um uso inusitado de esterilizações cirúrgicas femininas. Assim, com as mães que estão na faixa etária acima de 30 anos tendo encerrado as suas carreiras reprodutivas, são as mais jovens que estão tendo os filhos. As grandes proles de algumas décadas atrás são cada vez mais raras, e, agora, é um acontecimento bem raro ver uma mãe (de 30 ou mais anos) e a sua filha (adolescente) tendo filhos ao mesmo tempo. Quando a filha adolescente engravida, a atenção da 
mãe dela volta-se mais para o neto, esperado, já que ela (a mãe) não vai ter mais filhos. E quando se percebe que a faixa etária de 15 a 19 anos entre os jovens é a mais avantajada, é fácil entender por que ‘a gravidez na adolescência' se tornou foco de atenção da sociedade e de planejadores da população (CNPD, 1999). É importante frisar que gravidez na adolescência não é uma quebra de uma tradição - a quebra de tradição está no fato de as mulheres de 30 anos ou mais não engravidarem.

O Brasil, apesar de ter reduzido em muito a média de filhos por mulher, ainda manteve a média de 2,7 filhos em 1997, um número que representa quase o dobro da média japonesa. $\mathrm{O}$ significado desses filhos é bem diferente para os jovens pais brasileiros. A média de idade na primeira união no Brasil é bastante baixa (em torno de 22 anos) e, para atingi-la, é importante notar que nela se inclui boa parte dos que se casaram (legalmente ou não) antes de completar 20 anos. O mercado de trabalho brasileiro não absorve jovens com facilidade, e o sistema educacional não os retém, fazendo com que a procura de autonomia e independência do jovem brasileiro seja mais dificilmente construída em torno de padrões de alta capacitação, rentabilidade e, enfim, consumo. De fato, procuram-se os sinais de capacidade de consumir (especialmente no uso de roupas da moda), mas é muito modesto o nível de consumo permitido pela baixa renda da população. As pesquisas com os jovens pais demonstram que a chegada de um filho é valorizada muito positivamente por eles.

A opinião de médicos e muitos dos seus auxiliares, que chamam a atenção para os 'perigos' da gravidez na adolescência (explicitamente fisiológicas, implicitamente morais e econômicas), não encontra muito respaldo entre os jovens. Eles associam sua chegada a uma época em que as suas responsabilidades aumentarão de uma forma positiva. A afirmação de autonomia e liberdade pelo trabalho e pelo consumo encontra bloqueios significativos, mas a paternidade e a maternidade servem como ingresso rápido na categoria de pessoas autônomas e livres, com responsabilidades de adultos. Se a notícia da gravidez mexe com os pais até o ponto de eles reagirem com conselhos bastante duros e repreensões aos filhos, durante o próprio período de gestação a expectativa da chegada de um filho/neto produz, no mais das vezes, um efeito contrário, amenizando as relações até o ponto de promover maior união na família (Butto \& Silva, 1999; Scott, 2000).

O Brasil ainda está num nível de reposição populacional que implica crescimento da população, embora num ritmo muito mais gradativo que antes. Ainda almeja um crescimento populacional menor, e o nascimento de filhos de pais adolescentes sinaliza uma preocupação que aumenta as dúvidas sobre a possibilidade de se atingir esta meta. E também há vários anos os administradores governamentais vêm chamando a atenção para o fato de que o envelhecimento populacional contribui para a maior dificuldade de o sistema de previdência sustentar maior número de dependentes por trabalhador. Como ressalta o documento do CNPD (1998:17), de 1900 até 1970, "para cada 20 dependentes, somente dois tinham mais que 65 anos..." ao passo que, em 2000, "para cada 20 dependentes três terão mais que 65 anos". Se é preciso olhar mais para a população mais idosa, é importante notar que a proporção da população jovem dependente decresce, levando os planejadores a ver os próximos dez anos como 'uma fase favorável' no que concerne à composição etária do país. 
A visibilidade da 'gravidez na adolescência' termina, então, sendo vista com cautela, porque parece representar um retorno à alta fecundidade e, potencialmente, ameaça a capacidade de sustentar um número de idosos dependentes crescente. E, é bom lembrar novamente, os índices da OMS indicam que, mesmo que o brasileiro esteja vivendo mais, ele não está vivendo esta velhice melhor. Na medida em que os jovens pais reforçam a preocupação com sua incapacidade de educar seus filhos para o trabalho e de que estes sejam absorvidos pelo mercado de trabalho, esse comportamento reprodutivo será marcado como uma preocupação para o país.

\section{Trabalhando e Prevenindo: como os jovens vão, mesmo, SUSTENTAR OS IDOSOS?}

Pelo menos dois elementos cruciais entram na avaliação da atribuição aos jovens, pela sociedade, da responsabilidade de sustentar os idosos: trabalho e previdência. As preocupações são estruturais e morais. Por que estruturais? Porque dependem da relação entre as proporções das faixas etárias. Por que morais? Porque dependem da capacidade da sociedade de ativar um sistema de redistribuição da riqueza com a concordância dos seus participantes. Ou seja, depende dos jovens reconhecer a legitimidade da demanda apresentada pelos idosos, por vias institucionalmente formalizadas e por vias mais informais, de que sejam sustentados por quem está trabalhando. E ter trabalho também é uma questão estrutural e moral. Estrutural porque depende da organização da economia da nação entre todas as nações; moral porque o caminho da dignificação dos participantes da sociedade é o exercício do seu direito a um trabalho que permita uma qualidade de vida digna para si mesmo e para os seus dependentes.

A enorme diferença nas oportunidades de trabalho marca profundamente a forma pela qual se vive o cotidiano. Por um primeiro índice, o de desemprego, constatase, de um lado, um Japão que emprega a sua própria população e, de outro lado, um Brasil que não oferece oportunidades suficientes para absorver a sua própria população, mantendo muito alta a cifra de desempregados. O contraste é evidenciado diretamente quando se examina o fluxo migratório de, entre outras populações, brasileiros à procura de algum trabalho que remunere adequadamente (Yoshioka, 1995). Nesse fluxo, estudado por Yoshioka no âmbito das nações, mas também em casos específicos de bairros brasileiros, os dekasseguis ${ }^{4}$ são notadamente mais capitalizados do que os que nunca migraram, e isto se torna visível no padrão de vida desses brasileiros que se aventuram a ganhar a vida no Japão. Tal capitalização é observável na sua forma de viver no Japão, no seu patrimônio no Brasil, no dos seus parentes e, também, no que é mostrado na ocasião de visitas.

Em resumo, os migrantes 'trabalhadores no Japão' aparecem como ‘investidores' no Brasil (para não falar do consumo considerável). Outro índice, o de nível médio de renda, também evidencia o hiato. No caso japonês, o fato de poder trabalhar e ganhar bem se traduz na sustentação da imagem do 'homem trabalhador' como com- 
ponente de uma identidade nacional constantemente reafirmada, reforçado ainda mais pelos baixos índices de criminalidade e violência, que são um ponto de orgulho do japonês. ${ }^{5}$ As altas cobranças e o investimento de tempo em educação, muito conhecidos mundialmente, são um reflexo da vontade de assegurar uma capacitação para o mercado de trabalho que possa garantir uma boa situação socioeconômica na vida adulta. O jovem tem um caminho de trabalho traçado para ele, no qual a probabilidade de haver retorno aos seus esforços é bastante alta. Mas este mesmo jovem (e ainda mais a jovem mulher) não quer atrapalhar a sua ascendência no mundo do trabalho.

No Brasil, a valorização do trabalho em si é, também, muito grande. Isso fica muito evidente quando se examinam as categorias usadas para compreender a organização familiar de famílias pobres (Sarti ,1996; Scott, 1997). Mas o drama da falta de trabalho e renda frustra as tentativas de construir imagens nacionais mais duradouras em torno da noção de 'trabalhador'.

O Brasil contemporâneo está repleto de evidências de como a criação de redes alternativas de ganhos, por meio de atividades ilícitas, termina por promover um ambiente de insegurança marcada e projetar uma imagem de violência e de contravenção contra a qual a população precisa montar frentes unidas e solidárias. Mesmo entre ocupantes de postos importantes no governo do país, essa imagem de contravenção encontra constantes reforços. A ambigüidade entre 'trabalho' e 'esperteza' cria um clima de desconfiança sobre o valor de 'trabalho' no estabelecimento da identidade do cidadão. Um trabalho que é difícil de encontrar e que rende níveis ínfimos de renda não é uma base firme para a formação de um sistema de previdência confiável. O jovem fica desestimulado desde a idade escolar, como se verifica nos níveis de evasão escolar e nos conseqüentes baixos níveis educacionais. A universalização da educação no Brasil ainda é uma meta procurada timidamente, e deve continuar assim enquanto a capacitação individual do jovem não redundar em melhoras significativas no campo de oportunidades de trabalho. Com poucas oportunidades educacionais e de trabalho, o jovem não vislumbra facilmente uma vida de autonomia e responsabilidade, e alguns respondem com o paradoxo aparente de uma gravidez na adolescência, a qual permite o estabelecimento de uma família própria e o provável estreitamento de laços efetivos com os pais.

Para o japonês que trabalha, há muita gente idosa que depende da redistribuição da sua renda. Essa questão está sendo discutida seriamente no Japão, especialmente devido à constatação do baixo nível de reposição da população. Projeta-se uma razão de dependência crescente no futuro imediato (ver Tabela 1), o que implica que o japonês que trabalha terá de sustentar uma quantidade cada vez maior de aposentados. Isso é feito tanto pelos mecanismos previdenciários formais quanto pelas relações - aqui consideradas informais - de parentesco, mas há indicações da passagem progressiva de tal responsabilidade para instituições do Estado e para instituições formais privadas a ele associadas. Os parentes não deixam de oferecer esse apoio, mas, como se verá mais adiante na discussão sobre a organização domiciliar, verifica-se uma perda dessa função entre parentes hoje em dia.

Para o brasileiro que trabalha, há menos dependentes idosos (embora crescentes proporcionalmente, como já ressaltamos) e mais jovens. A aceitação da aposentadoria por velhice, que já beira meio século, é muito grande, mas as instituições gover- 
namentais que sustentam este sistema estão repetidamente presentes nos noticiários por causa de escândalos e 'rombos' perpetrados por pessoas que manipulam os dados e direcionam os ganhos em benefício próprio. Questiona-se menos a justiça da idéia dessa redistribuição de renda e mais o próprio processo de designação dos beneficiados.

A eliminação da categoria de 'aposentados por tempo de serviço,' um alvo prioritário de recentes modificações no sistema previdenciário, ${ }^{6}$ representa um esforço do governo de preparar o terreno para uma população mais idosa, jogando o peso das responsabilidades de pagamento para pessoas de faixas etárias mais avançadas e diminuindo os pagamentos para os que, pelo menos em termos ideais, ainda estão em idade de trabalhar. O governo divulga a necessidade de cuidar desses índices de dependência, e os estudiosos sempre insistem, no final dos seus artigos, na necessidade de garantir a continuação das rendas ameaçadas dos idosos (Debert, 1993; Goldani, 1994; CNPD, 1998; Beltrão, 1999; Berquó \& Baeninger, 2000).

Como no Japão, há modificações nos arranjos domiciliares brasileiros que indicam que os idosos estão morando sozinhos com mais freqüência, mas também há pesquisadores que reconhecem uma agregação de idosos às unidades familiares em função dos valores, mesmo reduzidos, que recebem de aposentadoria. Isso será discutido mais amplamente adiante, na parte sobre arranjos domiciliares, mas precisa ser entendido aqui como a parte informal do sistema de previdência. Interessante aqui é que voltamos a uma questão de ambigüidade semelhante àquela que se observou entre 'trabalho' e 'esperteza'; neste caso, tratando-se de 'justiça', porque os idosos merecem, e 'esperteza', porque os seus parcos ganhos ainda servem para complementar os ganhos também muito reduzidos dos mais jovens.

As diferenças pintam um quadro de contrastes interessante: apesar da sua alta densidade populacional, por causa do envelhecimento populacional e forte mercado de trabalho, o Japão se torna um país com trabalho e sem gente para contribuir com a previdência, ao passo que o Brasil é um país com menor densidade populacional ainda com gente na faixa etária de contribuir para a previdência, mas sem trabalho para assegurar qualquer contribuição. Em ambos os casos, a tarefa dos jovens de sustentar os idosos por sistemas formais (já tratados aqui) ou informais (como se verá adiante) torna-se árdua.

\section{Histórias e Culturas Diferentes na Queda da Fecundidade}

O pano de fundo de todas as comparações realizadas neste trabalho, iniciado com uma comparação de pirâmides etárias, é, sem dúvida, a grande diferença nas curvas de queda de fecundidade entre Japão e Brasil. O Gráfico 2 mostra que houve uma diferença de cerca de 30 anos entre Brasil e Japão no que concerne ao início de um decréscimo na fecundidade. O Japão começou de um patamar bem mais baixo que o Brasil (cinco filhos por mulher, comparado com oito no Brasil), e a sua queda está marcada por uma pequena oscilação e acréscimo decorrente dos efeitos na próxima geração do breve baby boom pós-guerra. 
Gráfico 2 - Quedas de fecundidade. Brasil/Japão

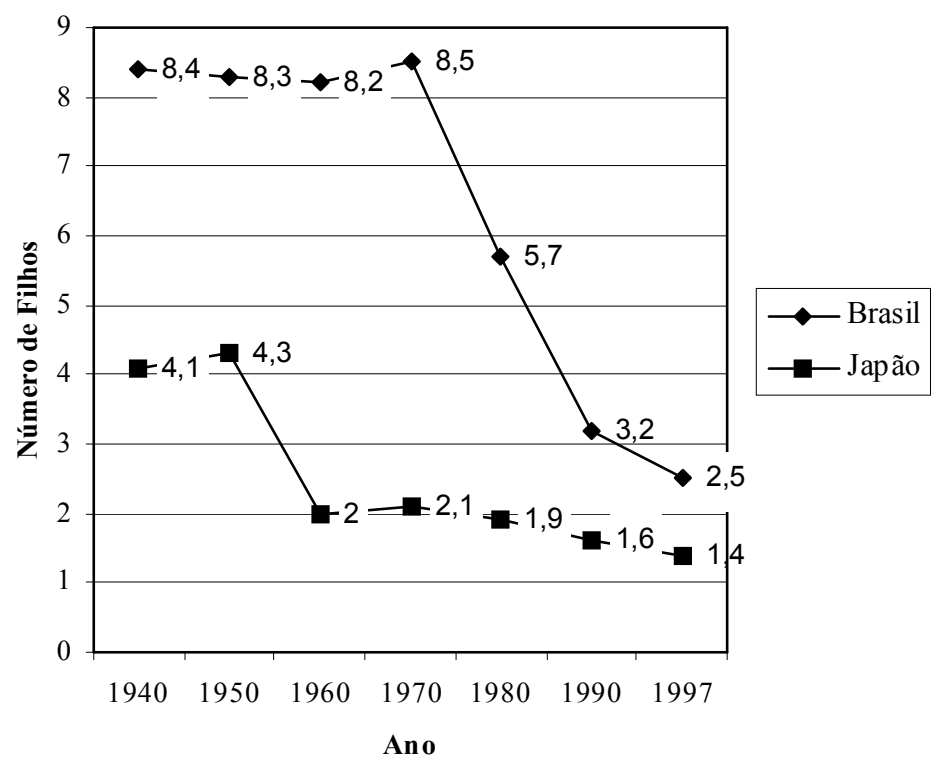

Fontes: Atoh, s. d.; Jica,1998; Formiga, Ramos \& Cunha, 1996; Fernandes, 2000.

Mas essas linhas escondem uma realidade muito complexa que precisa ser contada para se entender o que encadeia, em contextos diferentes, o processo de envelhecimento populacional. Para explicar as diferenças, recorremos a cinco fatores muito inter-relacionados que, embora não esgotem o campo, explicam boa parte das diferenças nas histórias:

- a inserção histórica do país na estrutura de poder global;

- o processo de planejamento e administração política;

- cultura, religião, maternidade e aborto;

- mulher e trabalho;

- medicalização, corpo e saúde.

\section{A INSERÇão histórica do PAÍS Na ESTRUTURa de PODER GLOBAL}

Em termos de população, o Japão tem poucas informações sobre os resultados da Segunda Guerra Mundial. Depois da guerra, sofreu uma intervenção do Exército americano no período conhecido como Ocupação, de 1945 até 1953. A política pósguerra americana foi de desmonte de estruturas adversas e fortalecimento das economias e políticas dos países derrotados, de modo que estes pudessem participar numa ordem global regida pelas trocas entre economias capitalistas nacionais e transnacionais.

A reconstrução do Japão, então, visava à sua inserção como parceiro relativamente igual na ordem global. Mas é importante também não perder de vista a maneira 
como os japoneses encaravam a derrota e a intervenção. Foi uma afronta que serviu para motivar o país, com uma história milenar, a demonstrar a sua capacidade de organização e recuperação. A chamada ao trabalho e ao esforço redobrado para compensar as perdas da guerra se construíram sobre uma base sólida de uma população organizada hierarquicamente e com forte lealdade às corporações em que se inseriam. Nesse quadro, no Japão pós-guerra a população sofreu um acréscimo bastante grande (imigração e um período curto de baby boom), mas logo em seguida o país enfrentou déficits habitacionais e problemas de bem-estar que associou com superpopulação (Muramatsu, s. d.), iniciando uma política de planejamento familiar em torno de 1950.

O Brasil, no mesmo período, foi um país jovem iniciando um processo de centralização marcada do Estado, e a sua associação à guerra foi como aliado que lutou no cenário de guerra européia. A dependência econômica do país em relação aos Estados Unidos e aos mercados monetários internacionais já esboçava sua inserção subordinada na ordem global. O aconselhamento e o apoio internacional no estabelecimento de órgãos administrativos e na criação de modelos ideais de desenvolvimento capitalista serviram para nortear um desenvolvimento, o qual se pautava na idéia de que o próprio processo de industrialização e urbanização contribuiria para uma nucleação e diminuição do número de membros da família. É somente quando ocorre a revolução socialista em Cuba e se torna evidente que a pobreza está se alastrando nos países do 'Terceiro Mundo' que se identifica a estrutura populacional de tais países como alvo mais direto e se procura incentivar uma queda na fecundidade.

\section{O PROCESSO de Planejamento E AdMinistraÇão Política}

Estreitamente associada à questão da inserção na ordem global ora analisada é a questão da cultura administrativa e de planejamento nos dois países. Enquanto a história japonesa passa por sucessivos e longos períodos de centralização com hierarquias sociais bastante rígidas e bem delineadas e com um aparato institucional estatal elaborado, a história brasileira, desde os tempos do Estado Novo, apresenta um Estado centralizado cujos aparatos institucionais estão em construção e constante reordenação.

A tentativa de operar de acordo com planejamento e administração sob a orientação de políticas governamentais faz parte da cultura japonesa desde antes da Segunda Guerra Mundial, e o governo de ocupação cuida de reforçar esse aspecto da cultura japonesa como um meio de facilitar a adesão dos japoneses ao projeto 'globalizante' capitalista com mecanismos administrativos de alta eficiência. Ao mesmo tempo, um dos grandes debates travados no Brasil é sobre como tornar o seu aparato institucional estatal mais afinado com as finalidades de planejamento e administração eficiente. É real a preocupação sobre o 'patrimonialismo' e a 'cordialidade' brasileiros, vistos como empecilhos à inserção do país no caminho de desenvolvimento capitalista, por fazerem com que os interesses particulares sejam postos acima dos interesses da nação (Buarque de Holanda, 1936; Da Matta, 1987).

Quando se trata de propor uma política populacional, concretamente, essa diferença na organização de instituições estatais redunda em maior facilidade de implantar e fazer cumprir decisões centralizadas, o que de fato ocorreu. Houve, ainda mais, uma 
decisão central no Japão - país territorialmente pequeno e com alta densidade populacional que vinha passando por períodos longos de emigração da sua população, seguido por um breve crescimento pós-guerra - de tratar o planejamento familiar e a limitação populacional como metas importantes a serem alcançadas.

De sua parte, o Brasil, receptor histórico de imigrantes, que se via como um país com fronteiras abertas, marchando para o oeste e ocupando vastas expansões de terras devolutas ou de fronteira (Velho, 1976) à procura de uma inserção mais plena no mundo desenvolvido (50 anos em 5!), não enxergava essas metas como explicitamente necessárias. Então, além de contar com um aparato menos eficiente que o japonês, enfrentou a inexistência de uma política populacional declaradamente a favor de planejamento familiar a ser implementada.

\section{Cultura, religiño, aborto E Materniddde}

Os índices de mortalidade materna, bem como de pobreza em muitos locais no país, espantavam os oficiais japoneses nos anos 50 e contribuíram para uma decisão cujo efeito revolucionou a tendência à queda da fecundidade. Em 1948, o país legalizou o aborto por razões da saúde da mãe e em 1949 acrescentou as razões de incapacidade material de criar um filho. Culturalmente, no Japão, essa decisão não encontrou grande oposição religiosa, ${ }^{7}$ pois nem o budismo nem o xintoísmo, as grandes religiões e filosofias de vida japonesas, condenavam a prática de aborto, por reconhecerem a validade do argumento da necessidade de garantir condições de vida dignas para os filhos.

De fato, nos muitos templos pelo país, há entidades religiosas budistas que recebem visitas de mães que abortaram e que pedem que não haja sofrimento para os filhos abortados, oferecendo estatuetas, mas a explicação dada pelos fiéis e pelos oficiantes dos templos é que, segundo essas religiões, as mães não são 'condenadas' pelo seu ato, apesar do fato de que terão de viver sabendo o que fizeram. $\mathrm{O}$ ato religioso de oferecer uma imagem no templo facilita o 'poder conviver' com o sempre difícil fato de ter realizado um aborto. Como o aborto foi legalizado, houve condições de realizálo em clínicas e hospitais ligados ao sistema da saúde pública, assegurando as condições sanitárias que evitassem mortalidade materna. A principal razão de abortos na sociedade japonesa, até hoje em dia, é, de longe, a incapacidade de criar os filhos.

No Brasil, a história e a cultura de tradição católica são totalmente outras. A alta valorização da maternidade se evidencia de muitas formas, como no marianismo, no grande número de 'Nossas Senhoras', na ênfase na condição de Jesus 'Filho' etc. A postura explícita e enérgica da Igreja na convicção de que aborto é pecado e resulta na condenação da mãe e na necessidade de pedir perdão sempre dificultou o estabelecimento de qualquer rede formal de assistência a mães que desejavam abortar. De fato, até hoje luta-se para conseguir apenas que as unidades de saúde observem a garantia constitucional de direito de aborto em casos de estupro e de ameaça séria à saúde da mãe. Tais adversidades levam a que os abortos no Brasil aconteçam em menor número e em condições sanitárias muito piores, contribuindo, inclusive, para a manutenção de altos índices de mortalidade materna. 


\section{Mulher e trabalho}

Após a Segunda Guerra Mundial, as mulheres japonesas estavam experimentando um reforço do modelo da família moderna, com 'homem provedor' e 'mulher em casa' (Atoh, 1999), e o primeiro filho era para ela a ocasião de sair de um mercado de trabalho crescente. A participação feminina na força de trabalho aumentou muito nos anos $60^{8} \mathrm{e}$, sem dúvida, os ganhos de estima pessoal, de autonomia e de bem-estar material que resultaram desta experiência foram fundamentais para as mulheres questionarem se 'ser mãe' - e, como resultado, se ausentar das atividades de trabalho talvez permanentemente - era uma compensação adequada quando comparada com a atividade de trabalho e o fato de poder fazer parte de uma unidade Dinks, ${ }^{9}$ em melhores condições econômicas.

Assim, o trabalho feminino japonês foi outro fator que reforçou a antecipação da queda de fecundidade dos japoneses, pelo menos moderadamente, no início, e bem mais fortemente a partir dos anos 70. Desde meados da década de 70, a participação da mulher na força de trabalho deixou de evidenciar a tradicional 'retirada' entre 25 e 35 anos, quando antigamente ela se dedicava quase que exclusivamente ao nascimento e ao cuidado dos filhos. Em 1990, as mulheres japonesas compuseram 39\% da força de trabalho (Meguro,1990). Tsuya (1994) mostra que, em 1994, 3/4 das mulheres japonesas casadas, em atividade reprodutiva, estavam ativas na força de trabalho.

A inserção da mulher no mercado de trabalho brasileiro foi mais gradativa (Bruschini, 2000), e, de fato, só se evidencia um crescimento muito significativo a partir da década de 70, quando o milagre econômico brasileiro aperta as economias das famílias brasileiras e as mulheres ampliam a sua atuação na economia remunerada. E continuou crescendo, pois, de 1981 a 1990 passou de 28,0\% para 35,6\% da força de trabalho ativa, embora os dados indiquem que o crescimento é de atividades de baixa qualificação e com remuneração em torno de apenas a metade do salário masculino (CNPD, 1998). Verifica-se uma reação semelhante à que ocorreu entre as japonesas: o reconhecimento da importância do trabalho para auferir renda (mesmo limitada), ganhar auto-estima e autonomia, cria uma esfera 'além da maternidade', na qual as mulheres procuram a valorização da sua participação societária e, neste processo, também avaliam diferentemente a alta fecundidade. É nesse período que a queda de fecundidade começa a se instalar, vindo a se efetivar durante a década de 80 .

\section{Medichlização, CORPO E SaÚde}

Um último ponto também vale ser tratado. O respeito japonês à qualidade da vida de acordo com a forma como esta se manifesta no corpo humano favorece a adesão a um estilo de vida, o qual abre um espaço para uma atuação médica que visa à integração entre diversas maneiras de procurar o bem-estar físico e espiritual. Sem nos reportarmos às tradições religiosas orientais conhecidas que visam a essa integração entre corpo e espírito (um campo 'fértil' para descobertas adicionais), mantemos o nosso foco no campo de saúde reprodutiva, em que o respeito ao corpo e à qualidade de vida é particularmente notável. Parece haver uma contradição entre esse respeito e a consecução de uma efetiva queda de fecundidade: a avaliação médica japonesa dos níveis de hormônios presentes na pílula anticoncepcional fez com que este método 
anticoncepcional fosse proibido no país até 1999, quando novas versões da pílula com níveis hormonais bem menores foram aprovados.

A abertura recente para o uso da pílula está resultando numa enorme preocupação com outro índice marcado da garantia de qualidade de vida do japonês: níveis muito baixos de contaminação pelo HIV (Aids) e outras doenças sexualmente transmissíveis. Por quê? O método anticoncepcional usado em 77,8\% dos casos no Japão, pelo menos até 1998 (Muramatsu, s. d.), é o preservativo, que serve também como barreira contra a contaminação dessas outras doenças. A liberação da pílula está sendo prevista como o provável início de um processo de declínio do uso do preservativo e provável aumento de doenças sexualmente transmissíveis, especialmente a Aids. Essa proibição por causa de níveis hormonais, quando somada ao respeito à vontade da mulher no tocante à decisão de abortar para evitar os altos índices de mortalidade materna e o declínio da qualidade de vida, mostra que, pelo menos num plano, a atuação médica no Japão tem preservado grande respeito ao corpo feminino.

No Brasil, a história da queda de fecundidade evidencia uma atuação médica diferente. Diante de uma política populacional nunca explicitada, mas evidentemente a favor de planejamento familiar, o uso da pílula anticoncepcional foi altamente estimulado (em 1996, o método era usado por 29,3\% de mulheres em idade reprodutiva) e estabeleceram-se grandes polêmicas sobre a atuação de instituições internacionais e profissionais da saúde neste processo. Essas instituições e esses profissionais eram excessivamente controladores, ou seja, promoviam os direitos reprodutivos das mulheres (Fernandes, 2000). O embate entre saúde reprodutiva e direitos reprodutivos encontrou um campo enorme de locutores que, até hoje, discutem sobre as implicações de intervenções na área de fecundidade para a autonomia feminina e para o bem do país e da saúde dos seus habitantes.

O Brasil tornou-se famoso pela alta incidência de esterilizações cirúrgicas femininas (laqueaduras) que, em 1996, foi o método anticoncepcional 'escolhido' por 56,8\% da população feminina em idade reprodutiva (CNPD, 1998; Fernandes, 2000). Somando $86,1 \%$ de todos os métodos contraceptivos, são dois métodos extraordinariamente eficientes em contribuir para a queda de fecundidade que vem ocorrendo desde a década de 80, mas é inegável que representam uma atuação médica muito menos 'respeitosa' ao corpo feminino. Como diz Fernandes, ao ressaltar a transferência do controle do corpo feminino das próprias mulheres para os profissionais da saúde, o Brasil sofreu uma 'intervenção branca' - branca porque nunca foi explícita e porque foi comandada pelos profissionais da saúde em suas batas brancas (Fernandes, 2000).

\section{Os Idosos nas Casas dos Jovens e os Idosos em Suas Próprias Casas}

A modificação dos padrões residenciais é uma pista para a compreensão das transformações das relações sociais entre as gerações. Fugindo, mesmo que apenas parcialmente, das considerações mais materiais que a discussão da previdência susci- 
tou, a visão sobre a queda de um padrão de continuidade intergeracional e solidariedade hierárquica em grupos de parentesco mais fechados, corporativamente, ${ }^{10}$ é comum a ambos os países, seja no Ie, ressaltado por Meguro (1985) e muito referido na literatura japonesa, seja na 'família patriarcal', tão citada na literatura sobre a identidade nacional brasileira (Freyre, 1967; Correia, 1983; Scott, 1998).

É importante reconhecer que os dados demográficos que fundamentam esse argumento têm sido repetidas vezes postos em xeque com a demonstração de que, historicamente, grandes contingentes de ambas as populações não tinham condições que correspondessem à criação de redes de solidariedade intergeracional tão singulares e solidárias quanto os dois conceitos de referência - Ie e família patriarcal - sugerem. Ou seja, a reificação da integração intergeracional sob a égide de figuras poderosas de referência em grupos de parentesco precisa ser entendida, prioritariamente, como parte de uma estratégia de criação de uma ideologia que favoreça a formação de uma identidade nacional integradora, e somente secundariamente, e com grande ceticismo, essa reificação pode ser tomada como reflexo de uma realidade demográfica de uma tendência notável, mas sujeita a comprovação.

Dito isso, é possível examinar onde residem e como residem os idosos nos dois países, e verificar o que se diz sobre as relações entre as gerações conforme as situações de moradia. No Japão, a tradição de coabitação intergeracional diminuiu de 76,9\% das pessoas acima de 65 anos residindo com os seus filhos, em 1970, para 68,7\%, em 1980 (Meguro, 1985), e continua em declínio (Statistics Bureau, 1998). Entre estas unidades multigeracionais, a preferência (em declínio também) recai sobre a situação em que os pais residem com o primogênito (masculino). Meguro afirma que, com as modificações socioeconômicas e a queda do modelo do $I e$, a convivência intergeracional resulta às vezes numa inversão que leva até o "isolamento e suicídio da geração mais antiga" (Meguro, 1985:13), quando antes era a geração mais nova a afetada pelos conflitos. Isso se reflete na composição de outras residências.

Em 1996, o grupo doméstico japonês apresentava uma média de 2,85 pessoas (Statistics Bureau, 1998). O número de unidades unipessoais entre os idosos está em franco crescimento, especialmente entre mulheres, denotando uma individualização e procura de autonomia tanto entre os filhos quanto entre os próprios pais, embora as pesquisas sobre contatos entre parentes que não coabitam mostrem que ainda perdura uma forte relação de afetividade e padrão de visitação entre eles.

Levantamentos indicam que, nos períodos de doença ou de morte de um dos pais, ocorrem algumas recomposições de grupos domésticos nas quais os mais idosos são reincorporados nos grupos dos seus filhos, mas que, mesmo assim, o aumento de unidades unipessoais é significativo, tendo triplicado nas últimas duas décadas, chegando a 2,8 milhões de pessoas (até 1996). Somando-se as residências unipessoais de idosos e as unidades com apenas idosos e pessoas solteiras abaixo de 18 anos (o que o bureau de estatísticas designa 'grupos domésticos de idosos'), é possível notar que essas unidades ${ }^{11}$ pularam, de 1975 a 1996, de 4,9\% de todos os grupos domésticos para $14,2 \%$, o que se traduz em mais de 6 milhões de pessoas residindo neles.

Mais da metade dos respondentes (até 49 anos de idade) de um levantamento nacional disseram que não tinham intenção de depender dos seus filhos quando atingiam 
a velhice. Essa falta de expectativa de dependência é mais marcante na cidade que no campo, atingindo quase dois terços da população. Mesmo que esteja declinando um número (eram 75\% há 15 anos), 50\% dos jovens ainda acham que "cuidar dos idosos é um dever natural ou é um bom costume", ao passo que os respondentes mais velhos demonstram uma preferência por serem cuidados em instituições oficiais, mais do que por seus familiares. Quando se trata de preferência por familiares, esta recai sobre a mesma geração (a preferência por cônjuges como cuidadores) e, secundariamente, e bem mais distante, sobre a geração inferior, especificamente sobre filhas cuidadoras (e não filhos, noras ou genros). As críticas à qualidade das instituições são mais contundentes entre as pessoas mais próximas de 50 anos, provavelmente porque tiveram experiências com essas instituições que as marcaram no cuidado dos próprios pais (Okazaki, 1994; Kuroda, 1994).

As projeções de Atoh (1999:204) anunciam a direção, já bem estabelecida, para a qual a condição dos idosos em famílias japonesas se encaminha: "a função familiar de cuidar dos idosos vai diminuir com a assimilação de mulheres na força de trabalho e o alargamento da ocorrência da família nuclear. Adicionalmente, o aparecimento de um grande número de idosos sem família e sem parentes se espera no meio do século XXI por causa da proporção aumentada de solteiros permanentes, de divórcios e de casais sem filhos". Exalta-se "o princípio básico de criar uma sociedade com participação igualitária de gênero fundada no individualismo" (Atoh, 1999:206; Meguro, 1992).

A sociedade japonesa adaptou muitos dos seus serviços governamentais e criou uma crescente economia 'prateada' dirigida aos mais idosos e cuidados especiais para os que não podem mais se cuidar (colocados grosseiramente na categoria de 'demência') (Atoh, s. d.:9-11). Mesmo assim, é interessante notar a firmeza com a qual a tendência predominante se estabelece e influencia propostas e políticas individualizantes e particulares, as quais, em vez de aliviar o peso do idoso na família e o peso do idoso para si mesmo e seus dependentes diretos, adotam medidas que vão forçá-lo a trabalhar por mais tempo, a viver com menos benefícios e com mais despesas - enfim, a se autoexplorar com o avanço da idade. Dito de outra forma, o idoso, de maneira ainda mais contundente do que a atual, no futuro dependerá ainda mais de si mesmo, e não dos seus familiares, que serão cada vez em menor número e cada vez mais ocupados na procura de recursos próprios.

No Brasil, como já dito aqui, o envelhecimento populacional está em outro patamar, e as transformações nos padrões residenciais intergeracionais indicam uma realidade que apresenta algumas semelhanças com o caso japonês, mas que guarda particularidades notáveis. Os dados que Berquó \& Baeninger (2000) apresentam mostram uma pequena e decrescente participação dos idosos como dependentes em casas de outros. Em 1995, 23,6\% das mulheres acima de 65 anos residiam nas casas dos outros, número que é significativamente menor que os $32,2 \%$ em 1970. Entre os homens, com igual declínio proporcional no mesmo período, apenas $6,9 \%$ dos idosos são domiciliados assim. Ou seja, a coabitação intergeracional como dependente, mais feminina que masculina, ${ }^{12}$ não constitui regra nem para mulheres, nem para homens. Morar sozinho é uma opção que apresenta um crescimento de 1970 a 1995, sendo mais acentuada para as mulheres $(85,1 \%)$ do que para os homens $(45,8 \%)$. 
Em 1995, 8,6\% dos homens idosos residiam sozinhos, em relação a 17,4\% das mulheres na mesma faixa, ${ }^{13}$ número médio que não se afasta muito da média japonesa de unidades unipessoais. As mulheres idosas também estão incrementando a sua participação na chefia de famílias monoparentais $(18,2 \%)$, enquanto apenas $6,2 \%$ dos homens idosos ficam como chefes de família sem companheiras. A facilidade do homem para se casar novamente e os benefícios que tal ação lhe traz fazem com que ele, mesmo idoso, se mantenha como membro de um casal à frente de uma casa em três de quatro casos $(75,6 \%)$, ao passo que para as mulheres isto só ocorre em um caso de três $(33,0 \%)$.

Camarano, Tarcom \& Carneiro (1999), numa análise estatística nacional, reportam que as famílias com idosos costumam ser menores que as famílias sem idosos, contando com três pessoas, em relação a 4,2 para as famílias sem idosos. Também mostram que essas famílias auferem rendas melhores, na média, do que as rendas das famílias mais novas. Concluem que o argumento de forte 'dependência' do idoso na família não se apóia nos dados, e insistem na enorme importância de rendimentos provenientes de aposentadorias e pensões. Isso reflete também o forte fechamento do mercado de trabalho brasileiro: mesmo quando os idosos não são um contingente da população tão significativo quanto no Japão, os seus rendimentos são supervalorizados, relativamente.

Sobre sociabilidade, Goldani (1994) - adepta do argumento de que a maior longevidade proporciona maior possibilidade de convivência entre as gerações, mesmo que em arranjos domiciliares separados - acredita que dados que apresentam arranjos domésticos separados não indicam nenhuma 'crise' na família, e sim novos desafios para a convivência (especialmente das mulheres de meia-idade que precisam cuidar de filhos e de pais idosos ao mesmo tempo). Debert $(1993,1999)$ ressalta que a própria coabitação com os filhos não constitui nenhuma garantia de boa qualidade de vida para os idosos, pois as pesquisas mostram que é fácil e freqüente marginalizar um idoso coabitante. Este só tem condições de aumentar a sua sociabilidade extradoméstica sem vigilância das gerações mais novas, e a melhora da sua qualidade de vida pode ser muito visível.

Autores continuam insistindo na importância dos idosos (e especialmente das idosas) nas famílias brasileiras - seja como articuladores(as) de redes amplas de relações entre gerações (Barros, 1987), seja como pessoas que sabem tocar a sua vida com maior independência e liberdade do que antigamente (Britto da Motta, 1999, 2000). Mesmo diante do fato de que a centralidade do papel dos "velhos mais velhos' na família diminui com o avanço da idade, Britto da Motta (2000) encontrou amplas interações entre as gerações nesse grupo acima de 80 anos. $\mathrm{O}$ recurso a asilos geriátricos ainda é uma prática pouco comum no Brasil, e não foi possível encontrar um estudo sobre 'expectativa de dependência' como realizado no Japão, mas pode-se arriscar um comentário sugerido pela literatura brasileira. A insistência japonesa na questão da 'dependência' pode estar escondendo tanto um preconceito quanto uma oferta generalizada de trabalho, que ofusca a possibilidade de enxergar as contribuições de idosos, com patrimônios estabelecidos e rendas significativas, para as suas famílias. 
Esse breve resumo comparado de arranjos domiciliares e relações intergeracionais indica que o Japão e o Brasil compartilham processos semelhantes: cada vez mais os idosos estão residindo sozinhos. O fato de não residirem mais em unidades de parentesco mais amplas e historicamente consagradas, como o Ie japonês e a 'família patriarcal' brasileira, precisa ser compreendido menos como uma indicação da queda de autoridade dos mais velhos do que uma modificação no lugar do discurso segundo o qual essas unidades são 'instituições fundantes' da nação e, portanto, chaves para a formação da identidade nacional. As pesquisas de demografia histórica questionam a força histórica desse padrão residencial, mostrando diversidades inesperadas no passado. Enquanto no Japão os que estão envelhecendo preocupam-se em não se tornar um peso para os seus filhos é bem evidenciada, no Brasil não acontece o mesmo. Os idosos, em ambos os países, detêm patrimônios próprios - fruto da sua herança anterior, do seu trabalho, de aposentadorias e benefícios aos quais têm direito, ou de mais de uma dessas fontes -, e isto cria uma diferença grande na qualidade da sua relação com as gerações mais jovens.

Dessa forma, o fato de residirem juntas só pode ser mais uma indicação de mudança na qualidade das relações entre as gerações, mas cuja avaliação precisa ser objeto de mais observação e reflexão. Se no Japão há todo um setor da economia que se dirige ao atendimento das demandas dos idosos, e no Brasil há uma indicação de que as famílias dos idosos conseguem uma renda per capita maior, é possível que a idéia de morar sozinho, ou com poucos dependentes, dê maior autonomia aos idosos e permita que se construam novas formas de inter-relacionamento domiciliar - continuando e ampliando costumes de visitas e de apoio, mas diminuindo a obrigatoriedade de convivência cotidiana.

O discurso sobre a velhice que cada vez mais enfatiza esse lado ainda não implica o fim de problemas de doença, morte e religião associados à reflexão sobre a fragilização do corpo e dos laços sociais que acompanha o avanço da idade (Debert, 1999). Mas, em muitos casos, não são o isolamento e a fragmentação que chamam a atenção, e sim as mudanças na valorização da qualidade de vida e das atividades dos indivíduos. Está ocorrendo uma passagem do tempo do idoso nas casas dos outros, e de muitos outros nas casas dos idosos, para um tempo em que o idoso está na sua casa, e os outros estão na casa deles.

\section{ENVELHECIMENTO E JUVENTUDE: UM RESUMO COMPARATIVO}

As Nações Unidas elaboraram, em 1999, uma tabela internacional sobre a questão de envelhecimento. Um resumo desses dados comparativos para o Brasil e para o Japão serve para relembrar alguns dos dados e argumentos aqui apresentados. 
Tabela 1 - Envelhecimento populacional. Japão/Brasil - 1998

\begin{tabular}{lrr}
\hline & Japão & Brasil \\
\hline Milhões de idosos (+60) & 28.603 & 12.839 \\
\hline \% da População acima de 60 & 23 & 8 \\
\% da População acima de 80 & 16 & 2 \\
\% Homens +60 casados & 86 & 79 \\
\% Mulheres +60 casadas & 51 & 40 \\
\% Homens +60 na força de trabalho & 49 & 44 \\
\% Mulheres +60 na força de trabalho & 21 & 11 \\
\% Mulheres/Homens +60 & 56 & 57 \\
\% Mulheres/Homens +80 & 67 & 65 \\
Razão de apoio* & 4 & 14 \\
Previsão de razão de apoio em 2050 & 2 & 6 \\
Esperança de vida aos 60 anos - homens (em anos adicionais) & 21 & 16 \\
Esperança de vida aos 60 anos - mulheres (em anos adicionais) & 26 & 17 \\
\hline
\end{tabular}

* Pessoas entre 15 e 64 anos por pessoas acima de 65 anos.

Fonte: United Nations, 2000.

Este estudo oscilou na sua atenção entre duas gerações, de jovens e de idosos, mesmo que tenha sido obrigado a passar por todas as outras para poder compreender a relação entre as duas. Partindo do princípio de que as histórias particulares de cada país e as suas culturas específicas precisam ser abordadas para que se possa situar a importância das relações intergeracionais que se apresentam por meio de dados demográficos, foi possível elucidar algumas questões com esta abordagem comparativa.

Japão e Brasil passam por processos de envelhecimento populacional. No Japão, com uma expectativa de vida de dez anos mais que no Brasil, proporcionalmente há três vezes mais idosos e a composição etária favorece numericamente os adultos entre 40 e 55 anos, que podem vislumbrar a chegada próxima da velhice. Com o crescimento negativo da população, são essas faixas mais idosas que tendem a crescer mais rapidamente. Ao chegar a 60 anos, o japonês ainda vislumbra uma expectativa de mais 23 ou 24 anos de vida, enquanto o brasileiro que chega a esta idade vislumbra mais 16 ou 17.

No Brasil, a faixa etária numericamente maior se situa entre 10 e 24 anos, o que reflete o desencadeamento mais recente (anos 1980) do seu processo de envelhecimento populacional em função da queda de fecundidade. Essa faixa mais jovem enxerga uma vida adulta pela frente. Com o passar de mais dez anos, as previsões são de que essas mesmas coortes continuarão sendo majoritárias (assim, no Brasil, a faixa maior passará para 20 a 34 anos).

Japão e Brasil demonstram preocupações diferentes quanto aos jovens e à saúde reprodutiva. Os jovens japoneses têm filhos tarde e de menos, e os brasileiros, cedo e demais. Viu-se aqui que o Japão "olha os seus jovens na expectativa de poder contar 
com quem sustente tanto o país quanto os pais no futuro, e enxerga um problema de baixa fecundidade que deseja corrigir".

No Japão, os jovens se conformam ao ideal generalizado (e realizado) de alto consumismo, seja pela apresentação de uma imagem de rebeldia e autonomia de confecção bastante dispendiosa, seja por uma dedicação plena à integração no mundo bem remunerado de trabalho e de casamentos tardios. Os pais se preocupam com a superproteção dos filhos, um acontecimento perfeitamente associado à diminuição no número de filhos por cada pai. Os filhos, quando poucos, são menos intercambiáveis. Aos nipônicos, quase se aplica o velho ditado brasileiro de que "quem tem um não tem nenhum", o qual denuncia a precariedade da garantia de sustento posterior que um único filho representa. Com tão poucos filhos, e filhos tão paparicados, como será possível que estes sustentem os idosos?

No Brasil, são os adolescentes e jovens que estão engravidando, fenômeno que o país identifica como um dos seus problemas principais. Com as mães acima de 30 anos esterilizadas, seus filhos adolescentes que se tornam mães e pais são mais visíveis do que antigamente. A incapacidade dessas mães (e desses pais) jovens de sustentarem os seus próprios filhos gera mais preocupação do que a sua incapacidade de sustentar os idosos depois. Para os próprios jovens, que não conseguem consagrar-se facilmente como 'adultos com responsabilidade' por meio dos estudos ou do trabalho, tornar-se pai/mãe jovem antecipa a sua chegada à vida adulta com uma fecundidade percebida pelos outros, e não por eles, como precoce.

Japão e Brasil têm economias com ofertas de trabalho e de remuneração radicalmente diferentes e com sistemas de previdência pressionados a contribuir para uma redistribuição justa de recursos entre quem trabalha e quem não trabalha. Com uma alta densidade populacional, envelhecimento populacional avançado e uma força de trabalho numerosa e bem remunerada, o Japão é "um país com trabalho e sem gente para contribuir com a previdência", ao passo que o Brasil, com menor densidade populacional, envelhecimento populacional incipiente, alto desemprego e baixa remuneração, "é um país sem trabalho e sem condições para assegurar a continuidade do sistema de previdência”. Em ambos os países há uma forte valorização do trabalho e do 'trabalhador nacional bem-sucedido', e a população procura seguir o modelo.

No Japão, o sucesso relativo da procura de trabalho vem associado a baixos índices de criminalidade e violência, enquanto no Brasil o desemprego e a dificuldade de encontrar outros meios de sobrevivência se associam a crescentes níveis de violência e à manutenção de uma ideologia que coloca, não sem ambigüidades, o 'malandro esperto' ao lado do 'trabalhador dedicado' na apresentação de uma identidade nacional.

As histórias e culturas diferentes dos dois países traçam trajetórias diferenciadas nas quedas de fecundidade. A inserção do Japão como país-chave no contexto da economia global capitalista se deu com o final da Segunda Guerra Mundial, quando, na reconstrução da economia dos países derrotados, o orgulho e a tradição nacionais japoneses comandaram uma dedicação forte ao trabalho e uma procura de demonstração de autonomia. As faltas do pós-guerra foram identificadas com superpopulação e rapidamente traduzidas em políticas explícitas de planejamento familiar (inclusive acesso a informações) e aborto legal no final da década de 40. O Brasil, nesse período, intensi- 
ficava a sua associação subordinada à expansão da economia capitalista, procurando trilhar um caminho de desenvolvimento traçado por economistas do Primeiro Mundo, e nunca identificou explicitamente planejamento familiar ou controle de natalidade entre as suas metas.

O planejamento centralizado japonês, com alvos bem definidos, incluindo planejamento familiar, se mostrou mais eficiente do que o planejamento central brasileiro, que lutava contra o patrimonialismo e a falta de recursos e não tinha planejamento familiar como meta explícita. O Japão identificou altos índices de mortalidade materna como um problema de saúde pública, e não encontrou grandes dificuldades, nem no plano religioso, para implantar legislação permitindo o aborto no meio do século, ao passo que a resistência católica e cultural ao aborto legal e a forte valorização da maternidade impediam tais ações no Brasil. Enquanto a noção da moralidade japonesa implica garantir boas condições de vida para quem nasce (e conseqüentemente permite abortos para quem declara não ter condições de garantir tais condições), a moral brasileira associa aborto a pecado e não permite aborto formalmente por razões de condições de vida, o que acarreta nascimentos não desejados e abortos realizados em condições extraordinariamente insalubres.

No Japão, a mulher entrou no mercado de trabalho mais de uma década antes da sua entrada mais maciça no mercado de trabalho brasileiro. Em ambos os países, os ganhos desse ingresso no mercado de trabalho para o status feminino foram tão significativos que redundaram na diminuição da vontade de ter mais filhos. Isso ocorre mais tardiamente no Brasil que no Japão.

Finalmente, percebe-se uma diferença no processo de medicalização e respeito ao corpo feminino: no Japão, os efeitos nocivos dos altos níveis hormonais da pílula anticoncepcional e o receio contra a esterilização cirúrgica irreversível, ambos desestimulados pela saúde pública, fizeram com que o método contraceptivo preferencial fosse o preservativo, e a saúde da mulher e do seu corpo fossem mais garantidos. No Brasil, houve uma 'intervenção branca', constituída pela omissão formal das autoridades e pela ampliação das práticas médicas de esterilização e de amplo uso da pílula, para garantir a redução da fecundidade. Houve uma medicalização da queda de fecundidade e, mesmo que tenha redundado em maior controle, pela mulher, sobre o seu corpo, o primeiro passo desse processo se deu com os médicos.

A vivência entre jovens e idosos sofre transformações que passam por uma desvalorização das unidades de parentesco mais amplas que historicamente têm sido referência para os dois países (Ie e família patriarcal). Os idosos estão residindo sós, numa atitude que sublinha a sua autonomia e liberdade tanto quanto, ou até mais que, a sua solidão. A experiência da ampliação do número de gerações e de arranjos residenciais vividos por pessoas num mundo de longevidade ampliada e fecundidade diminuída proporciona oportunidades para diferentes formas de construção das relações entre gerações. A evidência da preocupação dos japoneses de não se tornarem dependentes dos seus filhos é resultado, em parte, do seu tempo mais longo e mais agudo do processo de envelhecimento populacional e da preocupação com as relações materiais e espirituais entre as gerações. Ao mesmo tempo, muitos idosos brasileiros conseguem sua autonomia, respeitabilidade e, muitas vezes, inclusão nos ar- 
ranjos residenciais dos seus filhos com a ajuda de benefícios e aposentadoria de valores que, apesar de baixos, lhes outorgam a condição de um dos poucos cidadãos com renda segura.

Reiteramos aquilo que foi declarado no início do trabalho: por meio de uma comparação entre dois países aparentemente muito díspares, é possível enxergar melhor as dimensões dos problemas de população, reprodução e relacionamento entre as gerações num mundo de países que envelhecem e procuram rejuvenescer.

\section{NOTAS}

1 Para ler comparativamente as pirâmides etárias, é importante notar que a pirâmide japonesa tem mais detalhes e inclui 15 anos a mais que a pirâmide brasileira, mascarando graficamente a grande diferenciação no topo da pirâmide, onde o Japão extrapola em mais que o dobro a proporção de idosos acima de 75 anos.

2 Fui ao Japão com o apoio da Japanese International Cooperation Agency (Jica), no âmbito do programa de intercâmbio entre a Universidade Federal de Pernambuco/ Núcleo de Saúde Pública e a Jica do projeto Saúde Pública no Nordeste.

3 Esta pesquisa, iniciada em 1998 e em etapa final da primeira fase, foi realizada com apoio da Facepe (auxílio) e do CNPq (projeto Nordeste, auxílio e bolsas), com complementos significativos da UFPe e da Jica.

4 Imigrantes no Japão, originários de população japonesa no estrangeiro. No caso referido aqui, brasileiros de origem japonesa que voltaram para o Japão.

5 Esta questão de identificação da importância da não violência tem um contraponto interessante na valorização de artes marciais, tão conhecidas pelas gerações de freqüentadores de cinema e leitores de narrações históricas nacionais.

6 Basta pensar na rotulação promovida pelo presidente ao chamar os aposentados com menos de 50 anos de 'vagabundos' para sentir tanto a importância outorgada à idéia de atingir o alvo pelo governo como a dificuldade de estabelecer credibilidade para o argumento. O próprio presidente recebe um benefício desde idade inferior a 50 anos!

7 Sobre religião japonesa hoje, ver Nakamaki, 1994.

8 Segundo Meguro (1990:63), “os fatores que empurraram as mulheres para entrar no mercado de trabalho incluem níveis educacionais mais altos, uma ideologia igualitária, o aumento no custo de vida, o maior custo da educação dos filhos, ansiedade sobre as garantias para a velhice, liberdade de trabalho doméstico com a ajuda de eletrodomésticos, e o menor número de filhos".

9 Dinks = double income, no kids - renda dupla, sem filhos; ou, pelo menos, como mostra Atoh (1999), renda dupla e poucos filhos.

10 Meguro (1985:1) caracteriza a instituição do $I e$, historicamente relacionada aos Samurai, como uma instituição na qual "continuidade intergeracional tinha prio- 
ridade sobre ligações afetivas entre familiares. (...) sucessão de propriedade, linhagem e cuidado dos pais idosos se mantiveram como as preocupações principais da maioria".

11 No Japão, as estatísticas oficiais diferenciam a identificação das unidades unipessoais como sendo 'de idosos' (elderly) conforme o gênero: as mulheres são classificadas como 'idosas' a partir de 60 anos e os homens, a partir de 65 (Statistics Bureau, 1998).

12 Uma pesquisa que realizei sobre pessoas morando nas casas dos outros confirma essa tendência (Scott, 1990).

13 Ver detalhes sobre as diferenças de gênero nesses arranjos domiciliares em Scott, 2000 .

\section{REFERÊNCIAS Bibliográficas}

ATOH, M. Fewer children: trends and issues. Asian Medical Journal, 42(5):197-207, 1999.

ATOH, M. Social Policies in Low-Fertility and Rapidly Aging Societies: the case of Japan. Tóquio: National Institute of Population and Social Security Research, s. d. (Mimeo.)

BARROS, M. L. Autoridade e Afeto: avós, filhos e netos na família brasileira. Rio de Janeiro: Zahar, 1987.

BELTRÃO, K. I. Dependência da população idosa: uma visão previdenciária. Como Vai? População Brasileira, 1:3-17, 1999.

BERQUÓ, E. \& BAENINGER, R. Os idosos no Brasil: considerações demográficas. Textos Nepo, 37, 2000.

BRITTO DA MOTTA, A. Não Tá Morto Quem Peleia: a pedagogia inesperada nos grupos de idosos, 1999. Tese de Doutorado, Salvador: Faculdade de Educação, Universidade Federal da Bahia.

BRITTO DA MOTTA, A. Relações de Família dos Mais Idosos. Petrópolis: XXVI ENCONTRO ANUAL DA ANPOCS, 2000.

BRUSCHINI, C. Gênero e trabalho no Brasil: novas conquistas ou persistência da discriminação? (Brasil 1985-1995). In: ROCHA, M. I. B. (Org.) Trabalho e Gênero: mudanças, permanências e desafios. São Paulo, Belo Horizonte: Abep/Nepo/Unicamp, Cedeplar/ UFMG, 2000.

BUARQUE DE HOLANDA, S. Raizes do Brasil. Rio de Janeiro: José Olympio, 1936.

BUTTO, A. \& SILVA, J. M. Representações sociais da sexualidade e da reprodução na adolescência e serviços de saúde em São Domingos, Brejo da Madre de Deus, Pernambuco. Anthropológicas, 9:86-97, 1999. (Série família e gênero)

CAMARANO, A. A.; TARCOM, A. R. P. \& CARNEIRO, I. G. Idoso brasileiro: dependente da família? Como Vai? População Brasileira, 1:3-11, 1999. 
CNPD - National Population and Development Commission. Cairo + 5: report on Brazil. Brasília: CNPD, 1998.

CNPD - Comissão Nacional de População e Desenvolvimento. Jovens Acontecendo na Trilha das Políticas Públicas. Brasília: CNPD, 1999. 3 v.

CORREIA, M. Repensando a família patriarcal brasileira. In: ARANTES, A. et al. Colcha de Retalhos: estudos sobre a família no Brasil. Campinas: Unicamp, 1983.

DA MATTA, R. A família como valor: considerações não familiares sobre a família à brasileira. In: ALMEIDA, A. M. \& GONÇALVES, P. (Orgs.) Pensando a Família no Brasil. Rio de Janeiro: Espaço e Tempo, UFRJ, 1987.

DEBERT, G. G. Desbravando fronteiras e redefinindo padrões. Tempo e Presença. s.n:13-16, 1993.

DEBERT, G. G. A Reinvenção da Velhice. São Paulo: Edusp, Fapesp, 1999.

FERNANDES, M. Mulher, Família e Reprodução: do controle à intervenção branca, 2000. Dissertação de Mestrado, Recife: PPG Sociologia, Universidade Federal de Pernambuco.

FORMIGA, M. C. C.; RAMOS, P. C. F. \& CUNHA, M. H. S. Características Sociodemográficas dos Idosos Norte-Riograndenses no Periodo 1940-1991. Caxambu: ENCONTRO DE ESTUDOS POPULACIONAIS, X (ABEP), 1996.

GOLDANI, A. M. As famílias no Brasil contemporâneo e o mito da desestruturação. Cadernos Pagu, 1(1):67-110, 1994.

JICA - Japan International Cooperation Agency. National Health Administration in Japan Tóquio: JICA, 1998. $3 \mathrm{v}$.

JOICFP - Japanese Organization for International Cooperation in Family Planning. Population, Reproductive Health and Family Planning in Japan: a bird 's-eye view. Tóquio: JOICFP, 1999.

KURODA, T. Overview - undercurrent of family change. In: Population Problems Research Council/Mainichi Shimbun. In Search of the New Family Model: summary of twentysecond national survey on family planning. Tóquio: Population Problems Research Council/ Mainichi Shimbun, 1994.

MEGURO, Y. Changing Patterns of Multi-generational Linkages in Japan. Nova Iorque: XIIIth International Congress of Gerontology, 1985. (Mimeo.)

MEGURO, Y. Japanese family: change and continuity. In: National Women's Education Centre (Comp.) Women in a Changing Society: the Japanese scene. Bangkok: Unesco, 1990.

MEGURO, Y. Between the welfare and economic institutions: Japanese families in transition. IJJS, 1:35-46, 1992.

MURAMATSU, M. A Brief History of Birth Control/Family Planning in Japan. s. d.

NAKAMAKI, H. The Japanese and Religion: a consumer's perspective. Kansai Forum, 3(26):2630, 1994.

OKAZAKI, Y. Support and take-care of elderly persons. In: Population Problems Research Council/Mainichi Shimbun. In Search of the New Family Model: summary of twenty-second 
national survey on family planning. Tóquio: Population Problems Research Council/ Mainichi Shimbun, 1994.

SARTI, C A. A Família como Espelho: um estudo sobre a moral dos pobres. Campinas: Autores Associados, Fapesp, 1996.

SCOTT, R. P. Homens e Mulheres sem Cônjuges: tendências recentes em Pernambuco. Belo Horizonte: ENCONTRO NACIONAL DE ESTUDOS POPULACIONAIS (ABEP), VII, 1990.

SCOTT, R. P. A etnografia da família de camadas médias e de pobres urbanos: trabalho, poder e a inversão do público e do privado. Anthropológicas, 1(2):121-154, 1997.

SCOTT, R. P. Patriarcalismo e Idéias Salvacionistas. Recife: ENCONTRO DO GT INTERNACIONAL IDENTIDADES NA AMÉRICA LATINA: ODEP, PGOA E FRAGMENTAÇÃO NA AMÉRICA LATINA, V, 1998. (No prelo)

SCOTT, R. P. Homens, Domesticidade e Politicas Públicas de Saúde Reprodutiva, RECIFE: SEMINÁRIO HOMENS E POLÍTICAS PÚBLICAS, 2000.

STATISTICS BUREAU, Management and Coordination Agency. Statistical Handbook of Japan 1998. Tóquio: Japan Statistical Association, Gov. of Japan, 1998.

TSUYA, N. O. Employment of married women and attitudes toward family policy in Japan. In: Population Problems Research Council/Mainichi Shimbun. In: Search of the New Family Model: summary of twenty-second national survey on family planning. Tóquio: Population Problems Research Council/Mainichi Shimbun, 1994.

UNITED NATIONS. Population Ageing 1999. Nova Iorque: Population Division, Department of Economic and Social Affairs, 2000.

VELHO, O. G. Capitalismo Autoritário e Campesinato: um estudo a partir da fronteira em movimento. São Paulo: Difel, 1976.

YOSHIOKA, R. Por que Migramos do e para o Japão. São Paulo: Massao Ohno, 1995. 


\title{
6 \\ Envelhecimento, Relacões de Gênero e o Papel das Mulheres na Organização da Vida em uma Comunidade Rural
}

\author{
Rita Maria Heck \& Esther Jean Matteson Langdon
}

O processo de envelhecimento apresenta variações que são constituídas socialmente nos diferentes grupos sociais de acordo com a visão de mundo compartilhada em práticas, crenças e valores. A visão clínico-biológica não contempla essa perspectiva, ao diferenciar as fases da vida em infância, juventude, fase adulta e velhice, seguindo uma ordenação linear cronológica de transformações do corpo. Segundo essa explicação, ocorre uma progressiva deterioração das funções vitais, em que o envelhecimento é caracterizado por um período de falência gradativa dos órgãos, agregado a características como tristeza, abandono, desrespeito, exclusão dos meios de produção, carências afetivas e materiais (Velasquez et al., 1989). Esse referencial se vincula a uma explicação moderna e produtiva da noção de pessoa. Segundo a Organização Mundial da Saúde, idoso é a pessoa com 60 anos ou mais, população estimada, no ano 2000, em 600 milhões em todo o mundo. No Brasil, a projeção para 2025 é de 32 milhões de pessoas idosas (Tavares \& Anjos, 1999; Kalache et al., 1997).

Tal discussão quantitativa, cronológica e homogênea, com relação ao idoso, é fixada em parâmetros que não incluem a perspectiva cultural. Por conseqüência, é limitada quando se quer compreender, em seu contexto, o envelhecimento. $O$ aspecto da cultura é importante para se compreender o ciclo da vida em que a morte é uma etapa que apresenta variações nos diferentes grupos sociais que compõem a complexa sociedade brasileira.

Há diferentes abordagens com relação ao termo 'cultura'. Nós partilhamos da proposta de Geertz (1989), na qual a cultura significa ação humana, o vivido no cotidiano pelas pessoas, as diversas interpretações que formulam, dia após dia, as formas como estas se reproduzem, de acordo com os significados de vida, morte e do universo. Esses valores estão relacionados ao sistema simbólico partilhado coletivamente.

Assim, o envelhecimento deixa de ser apenas uma fase biológica, passando a ter diferentes construções de acordo com as relações de poder, as expectativas dos papéis sociais das pessoas no grupo, as relações de gênero e os conflitos que fazem parte da vida, podendo encaminhar situações de readaptação, invenção de valores e/ou exclusão.

Pesquisando um grupo de colonos ${ }^{1}$ alemães no Rio Grande do Sul, Heck (2000) observou como são socialmente construídas as relações de gênero e a rigidez com que se moldam os papéis do homem e da mulher. Na visão de mundo desse grupo, há uma 
série de regras que precisam ser seguidas desde a infância e que são socialmente reafirmadas até a morte. A pesquisa, que tinha como objetivo investigar os suicídios rurais, mostrou um dado interessante com relação aos homens, que, na fase do envelhecimento, não têm espaço social devido à rigidez do seu papel no grupo; morrem mais, se comparados às mulheres, que organizam outra dinâmica de vida. As mulheres, principalmente, a partir da década de 90 , quando conquistaram a aposentadoria rural, ${ }^{2}$ introduziram a possibilidade de viver de forma sadia em espaço independente, dispondo de tempo e dinheiro para reforçar as relações sociais. Protagonizam, nessa experiência, uma valorização da identidade, uma nova possibilidade de envelhecer por meio da motivação e da participação no contexto social.

\section{Metodologia}

A pesquisa da qual fazem parte os dados aqui apresentados foi desenvolvida no ano de 1998 no município de Santo Cristo (RS). O trabalho consistiu em uma etnografia na qual foram utilizadas diferentes técnicas de pesquisa, como observação participante, entrevista semi-estruturada individual com informantes-chave e validação dos dados em grupos focais. A pesquisa de campo se estendeu por sete meses, período em que foi possível aprender sobre a visão de mundo daquele grupo social, que apresenta valores bastante seletivos com relação à aceitação de pessoas externas ao grupo.

Três credenciais foram importantes para a concretização da pesquisa: primeiro, o domínio da língua alemã, a qual é fluentemente falada no cotidiano; segundo, a condição de mulher casada, que possibilitou às pessoas confiarem assuntos só abordados depois de uma 'certa experiência na vida'; e terceiro, a referência a um grupo familiar, mesmo distante, mas que podia ser situado como pertencente à visão de mundo dos colonos, o que foi fundamental para o acolhimento em suas casas.

\section{Caracterização da População do Estudo}

Santo Cristo ${ }^{3}$ é um município pequeno na região noroeste do Rio Grande do Sul. A população é composta por 15.048 habitantes: 9.023 residem no meio rural e 6.025 na área urbana (IBGE, 1996). Na década de 60, a população localizava-se quase que exclusivamente no meio rural. ${ }^{4}$ Essa realidade foi mudando com as migrações e o êxodo rural. Nos últimos dez anos, formaram-se duas vilas que incharam o espaço urbano. Os núcleos rurais, num total de 35 comunidades, ${ }^{5}$ também passaram por uma transformação, conformando pequenos povoados (10-15 casas) de casais com maior idade, principalmente viúvas, que preferem residir próximo à igreja, à sociedade recreativa e à escola.

A distribuição da população por faixa etária e a comparação por sexo podem ser acompanhadas no Gráfico 1, em que percebemos que as mulheres são maioria na fase do envelhecimento, em comparação com os homens. 
Gráfico 1 - População de Santo Cristo de acordo com a faixa etária e o sexo

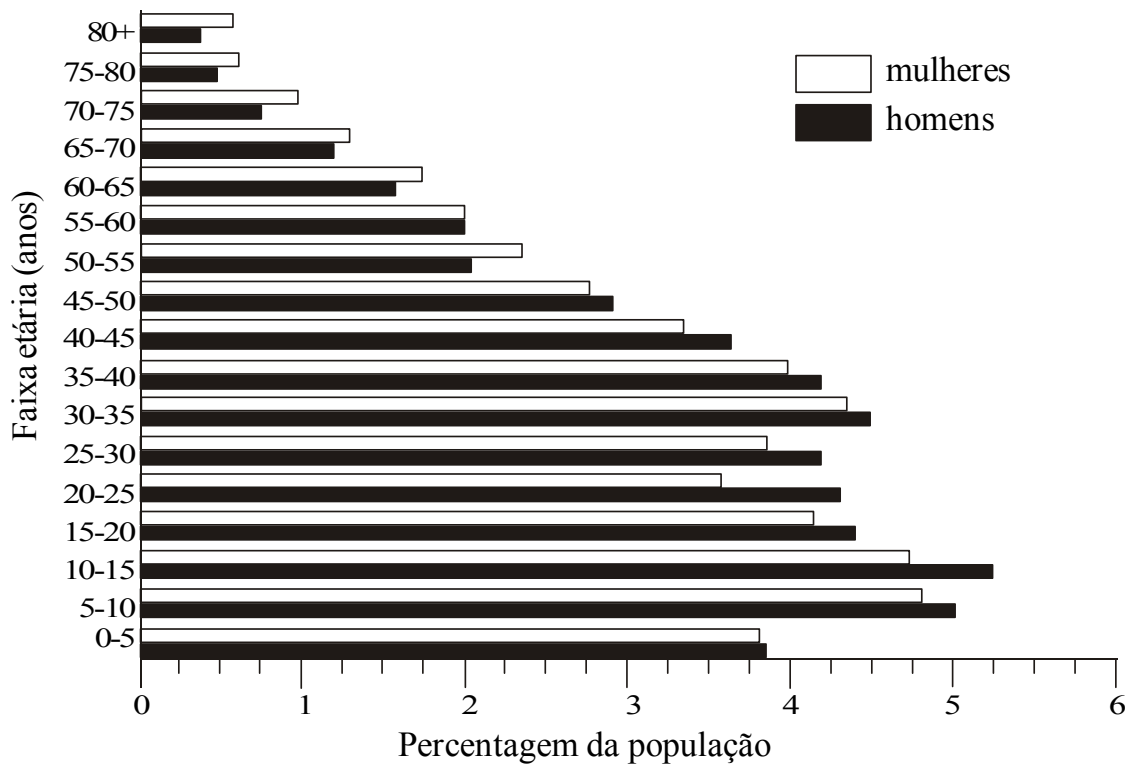

Fonte: IBGE, 1996.

Segundo os dados da Empresa de Assistência Técnica e Extensão Rural (Emater, 1992), ${ }^{6}$ as propriedades rurais têm em média 10,5 hectares, caracterizando-se como minifúndios. A produção agropecuária está voltada para uma economia com uso intensivo da terra, cultivando trigo no inverno e soja ou milho no verão.

A produção do leite é uma das potencialidades econômicas que garante renda mensal às famílias. No entanto, há diversas exigências para a entrega do produto: produção mínima de 50 litros/dia e aprovação nos testes de sanidade e higiene cobrados pela indústria. ${ }^{7}$ A suinocultura, por sua vez, está em decadência nas propriedades menores, e a maioria dos criadores - que antes tinham de três a cinco matrizes desativou a produção, alegando que o preço do suíno no mercado estava muito baixo. Somente os colonos associados à Associação de Produtores de Suínos (Apsat) ou integrados à Sadia (agroindústria) fazem a 'terminação' (engorda) do porco e se mantêm na atividade. Essa mudança no cenário da produção pecuária, que antes servia como complementação de renda, tem levado muitos colonos a se empregar em atividades fora da propriedade. ${ }^{8}$

Como conseqüência desse processo, novas situações sociais surgiram e alteraram os padrões de consumo entre as pessoas. Ao mesmo tempo, os colonos ${ }^{9}$ jovens intensificaram as migrações para as periferias das cidades, que antes estavam voltadas para novas frentes agrícolas no norte do Brasil e até o Paraguai. Com isso, o perfil da população se alterou. Segundo informações da Secretaria Municipal da Saú- 
de, $20 \%$ da renda que circulam no município são oriundos de aposentadorias e pensões pagas pelo Instituto Nacional do Seguro Social. Essa renda é tão significativa que as comunidades rurais deixam de promover eventos sociais se não tiverem apoio dos aposentados, diante do risco de as despesas com as promoções recreativas não serem cobertas.

As articulações associativas fazem parte do modo de vida desses colonos. Desde a colonização, ocorreram diferentes iniciativas: caixas rurais, cooperativas de comercialização (Santo Afonso, Bom Princípio, Mista Santo Cristo), Apsat e Associação Santo-Cristense de Agricultores (Asca), que atualmente é a Cooperativa de Agricultores de Santo Cristo (Copas). Além das experiências associativas voltadas para a economia, ${ }^{10}$ destacam-se o sindicato dos trabalhadores rurais, as sociedades recreativas em cada comunidade, os clubes do lar, os clubes de mães, os grupos de idosos, iniciados em $1990^{11}$ e vinculados à Secretaria da Saúde, e outros grupos, como a pastoral católica. ${ }^{12}$

A vida se caracteriza pelo cotidiano de trabalho na roça, marcado por encontros dominicais nas igrejas católicas e nas sedes sociais existentes em cada núcleo rural. Qualquer reunião de caráter festivo e solene é prenunciada pelo sino e começa com o ritual da missa ou culto. Os símbolos e a prática do catolicismo são marcantes nesse grupo, que tem uma história de colonização influenciada pelos padres jesuítas. Em decorrência, criou-se uma situação pouco atrativa para outras religiões devido ao crivo imposto a partir da idade escolar - os alunos precisavam ter batismo católico para freqüentar a escola, que era sustentada pelos colonos. Até 1930, os professores ensinavam em língua alemã, quando houve a nacionalização das escolas, e o ensino passou a ser ministrado em língua portuguesa.

O índice de alfabetização está entre $90 \%$ e 100\%. A maioria da população tem primeiro grau (atual ensino básico) incompleto - isso porque as escolas do meio rural ofereciam apenas o ensino até a quinta série do primeiro grau. Observamos que há uma preocupação em mudar essa realidade com a introdução do transporte escolar para a cidade. Entre os adultos, a maioria lê e fala com muita dificuldade o português, preferindo comunicar-se em dialeto alemão (hunsrük ou russich). Os mais jovens, ao freqüentarem a escola, não aprendem a língua alemã, apenas o português. Em casa, falam alemão, o vocabulário alemão pobre é complementado pela inclusão de palavras do português. Não existe casa sem televisão ou rádio, o que favorece o desinteresse pela leitura. Na prática, somente as pessoas mais idosas assinam revistas religiosas, geralmente na língua alemã, pois não tiveram oportunidade de freqüentar uma escola pública de língua portuguesa.

$\mathrm{Na}$ alimentação, contrastam os pratos dos dias de festa e domingo, que consistem de churrasco, maionese, galinhada e cerveja, com aqueles do cotidiano, feitos de feijão, arroz, batata, massa, mandioca, carnes (suína, bovina e aves), pão de trigo (em poucas casas ofereceram pão de milho), salame, ovos, melado e schimier de diversas frutas, nata, leite, café, chimarrão (folhas e talos de erva-mate), cuca, ${ }^{13}$ diversos tipos de bolachas, verduras e frutas variadas (as cítricas são consumidas nas estações de outono e inverno, ao passo que melancia, uva, pêra, maçã, pêssego, butiá, goiaba e abacaxi fazem parte do cardápio da primavera e do verão). 
No município, funcionam quatro conselhos de desenvolvimento (Agricultura, Educação, Indústria e Saúde) que se reúnem periodicamente e discutem alternativas para problemas como desemprego; migração; falta de agroindústrias e de formação para agricultores; ausência de infra-estrutura adequada, água potável e telefone em todas as propriedades; e o risco de as crianças perderem os vínculos com as localidades rurais. Outro problema é o acesso limitado dos colonos ao Hospital de Caridade. Embora tenha caráter filantrópico e vínculo com o Sistema Único de Saúde (SUS), o tratamento é caro e os leitos são restritos, sem transparência administrativa. Apesar desses focos em discussão, Santo Cristo, conforme os dados da Fundação de Economia e Estatística, ${ }^{14}$ é o vigésimo município com melhor nível de vida do Rio Grande do Sul, onde a expectativa de vida dos homens e das mulheres tem aumentado, a mortalidade infantil praticamente não existe e há investimento em programas de saúde preventivos.

\section{Identidade, Relaçôes de Gênero e Papel Social}

Na compreensão de mundo do colono, há uma acentuada valorização do corpo físico como instrumento de trabalho. É este que confere ao sujeito qualidades que dignificam a identidade, enquanto os sentimentos devem ser sublimados, são parte das qualidades invisíveis do indivíduo, que se anulam. Observa-se um direcionamento para o desenvolvimento de certas partes do corpo, que darão qualidades de destaque na vida adulta, atribuídas ao feminino e ao masculino. Por exemplo: a mulher é orientada para aprimorar tudo que se relaciona à habilidade manual, o que explicita delicadeza, sem que haja um vínculo direto com ganho econômico (fazer almoço, lavar roupa, fazer limpeza, cuidar dos filhos), enquanto o homem é levado a exercitar e desenvolver a musculatura de todo o corpo, exercendo atividades como colher soja, lavrar, erguer peso, tratar de porcos, domar animais, contrastando com a delicadeza, qualidade permitida somente à mulher.

Essas características, construídas num modelo de família em que a produção é atribuição do homem e a casa ocupação da mulher, se contradizem na atualidade, não correspondendo mais à distribuição conciliatória de valores, em que as qualidades ligadas à personalidade estavam em equilíbrio com a possibilidade de perpetuação do modelo. É importante frisar que os padrões tradicionais foram readaptados e continuam a se manifestar, mas impõem variações. Existem situações nas quais homens secam a louça, seguram as crianças em público (durante o ritual da missa) e auxiliam na ordenha das vacas. As mulheres participam da vacinação e da alimentação dos porcos, realizam atividades não mecanizadas da lavoura, assumem parte da contabilidade que exige controle cotidiano, como anotações da quantidade de litros de leite entregues à indústria por dia etc. Essas são manifestações impulsionadas pelas mudanças econômicas, principalmente decorrentes do processo de modernização da agricultura, que reflete, na propriedade familiar, a necessidade de maior diversificação, qualidade e agregação de valor aos produtos. 
Atualmente, vive-se nas famílias uma contradição entre a necessidade de pensar no futuro dos filhos e a sua utilização como força de trabalho. Com a redução da área nas propriedades, não é mais possível manter todos os filhos ${ }^{15}$ exclusivamente na atividade agrícola. Uma das alternativas adotadas pelos colonos de maior posse é custear o estudo dos filhos. Entretanto, a descapitalização progressiva do mercado agrícola e a necessidade de investir em tecnologia se acrescentam aos custos da educação, ${ }^{16}$ que, para a maioria dos colonos, estão além de suas possibilidades. Ao mesmo tempo, na expectativa dos pais, os filhos são um investimento que deve retornar à propriedade como força de trabalho sem remuneração.

Nós aqui temos a administração em conjunto. Já tinha uma vez e chegou num ponto que nós tivemos que separar, porque não dava mais para a comida. Sou sincera. Naquela vez não tinha solução, então ficamos individuais. São quatro irmãos da parte do meu marido, cada casal tem três filhos. Então, desta vez, foi os jovens que acharam que tinha que dar, não tem alternativas. Então nos convenceram e nós começamos de novo no conjunto. Então tudo é dividido, e com a graça de Deus está indo, nós temos tarefas e tudo é distribuído. Com eu e meu marido é as galinhas, temos duas entrega por semana. Como hoje acabamos há pouco o abate, entregamos limpo para comercialização, às três horas vem buscar. Tudo na propriedade é aproveitado: as laranjas, as hortaliças, tudo que é transformado. As terras, tudo planejado e plantado em conjunto. O leite é a principal renda líquida do mês. Os porco para engordar, somos tratadores, mão-de-obra, ganhamos por quilo de porco entregue, é dos O... Este é um negócio à parte, não é coletivo. Eu e meu marido achamos que dava para assumir, só tratamos, é se rebaixar para menos que empregado, mas como temos que cuidar as galinhas, então dava. No coletivo, todos têm horas iguais ou tarefas equivalentes. Uma vez por semana, temos que planejar e discutir. Então este ano compramos mais este pedaço de terra. Ainda não pagamos, precisamos para pastagem. Os filhos homens conseguimos incluir todos nas atividades de trabalho. Agora, cada um [cada família] libera um para continuar estudando. Precisamos de gente com estudo. Estudam à noite, então dá certo. As meninas temos agora que resolver, estas estão sobrando, não conseguimos encaixar, estão na escola, mas alguma alternativa temos que criar. A minha tem nove agora. Eu coloco para fazer o serviço de casa, mas só isso para elas não pode ser, não é lucro na propriedade. Sozinha também ainda não vai muito, também não ligo tanto. A casa fica por último, faço o que posso de noite. (sexo feminino, 45 anos, casada)

A nova perspectiva vincula à família a idealização de uma organização em que a economia produtiva é um fator importante, muito mais necessária em relação ao controle da mão-de-obra, da valorização do trabalho como ganho econômico, e expõe o contraste das meninas que, mesmo crianças, passam a ser um explícito ponto de preocupação: "estão sobrando". O contraste com relação às meninas, que antes era pouco destacado, atualmente é motivo de reflexão. Compreendem que devem ser valorizadas em igualdade, ao mesmo tempo que as tarefas de manutenção da casa ficam em segundo plano. Essa foi uma inquietação também verbalizada por outras mulheres, que lamentam a falta de tempo para se dedicar às tarefas da casa. Paralela- 
mente, falam da sua satisfação em participar da produção econômica do leite, no projeto assumido pelo conjunto da família.

A mulher solteira, mesmo que atinja sua autonomia financeira (graduando-se num curso universitário ou exercendo outra profissão), não conquista sua independência. Da submissão aos pais passa, com o casamento, para a do marido. O casamento deve ser realizado na comunidade de procedência da mulher e previamente programado no orçamento de ambas as famílias.

Eles nem noivaram ainda. A gente já pediu várias vezes quando. Ele não fala. Aqui tem um boizinho para a festa do casamento, então vai ter que contar antes, mas primeiro a namorada quer terminar o curso e também vai querer um emprego. Depois, eu acho que não vai demorar e ele vai encomendar o boizinho. (sexo feminino, 67 anos, viúva)

Enquanto as mulheres são moldadas para a submissão, o filho homem é estimulado a encaminhar-se de forma autônoma na vida. O estudo é uma das possibilidades de ganhar seu próprio sustento. Nesses casos, há necessidade de conciliar trabalho e estudo. O serviço militar, em algumas situações, é uma oportunidade importante; no entanto, a falta de higiene na arcada dentária e a depreciação dos dentes, além do baixo nível de instrução, têm sido motivos de reprovação na seleção. Para aqueles que conseguem ingressar no serviço militar, este tem caráter delimitador. Geralmente, experimentam a primeira saída de casa, administram seu próprio dinheiro e se definem pelo abandono da atividade de colono.

Quando existe um único filho, desde o princípio, ele é desencorajado pelos pais a se dedicar aos estudos. Com a justificativa da baixa escolaridade, consegue se desvencilhar do serviço militar obrigatório e, automaticamente, tem a preferência, em relação às filhas mulheres, para substituir o lugar do pai no dia em que este se ausentar do comando da família.

O rapaz tem que assumir. O pai não está ali, então ele tem que assumir, adolescente, 17 anos, tem. Então gritou que tinha que bater em qualquer um que estava dentro de casa. Ele era o homem, agora. (sexo feminino, 31 anos, casada)

O homem, na vida adulta, é pressionado para o casamento. $\mathrm{O}$ celibato, que era pouco comum e obrigatoriamente tratado como anormalidade, passa a ser percebido numa nova perspectiva.

Estes que ficam mais para trás não é opção... Tem uma gente que tem na base 2530 anos aí e não tem namorada ainda. Para mim, acho que não tem chance... As gurias que saem do interior e vão trabalhar de empregada não querem mais o rapaz... Podem ser das famílias mais simples, mais humildes, mais pobres, mas quando estão meio ano na cidade, não querem mais saber dos rapaz do interior. Elas conseguem emprego mais fácil porque pegam de doméstica. (sexo feminino, 39 anos, casada)

Parte desse quadro emergente de solteiros era, até o final da década de 80, encaminhado para a formação religiosa (seminários de formação de padres ou irmãos). $\mathrm{Na}$ atualidade, essa opção tem sido menos acionada, devido ao custo dos honorários 
que recaem sobre a família do colono. ${ }^{17}$ Estudos feitos por Grossi (1990) levam a compreender a relação entre os conventos e as famílias camponesas da região Sul, discutindo o celibato feminino, mostrando o convento como maneira de as mulheres escaparem da autoridade do pai, receberem educação e poderem viajar. Essa explicação se aproxima da perspectiva dos homens em sua relação com os seminários.

Até o presente, uma parte da formação diocesana dos padres (que está bastante reduzida) é feita num imenso seminário, Padre Adolfo Galas - localizado no limite urbano de Santo Cristo, onde funciona um curso de filosofia -, exclusivo para os internos. É uma honra para uma família ter um filho padre, que é símbolo de autoridade. De acordo com os colonos, houve um desinteresse vocacional religioso diante de uma nova proposta da Igreja católica de estimular o exercício de atividades leigas, que são assumidas por casais, mas os padres ainda desempenham papel de destaque nesse contexto, assim como as freiras.

O 'bom partido', inicialmente, é aquele que, com a ajuda dos pais, conseguiu adquirir uma área de terra e/ou foi escolhido para administrar a propriedade paterna. Essa escolha não o isenta do pagamento de partes iguais aos demais irmãos herdeiros (homens e mulheres). Essa negociação, muitas vezes, é explicitada pelo patriarca da casa, que formula uma proposta razoável de preço de pagamento do herdeiro para os demais irmãos (é comum negociarem não em dinheiro, mas em quilos de porco ou sacos de soja). A intermediação também é feita por um filho ou tio padre, que são pessoas extremamente respeitáveis, tanto na família como na comunidade. É a eles que se recorre, buscando conselhos e orientação, em momentos de conflito.

Hoje não fica mais muita herança. No geral, é distribuído entre todos. A herança em si, o que fica em casa, geralmente ele não ganha. Para mim... quando o pai consegue ajudar ainda comprar um pedacinho de terra para o filho... este consegue se manter colono. (sexo feminino, 35 anos, casada)

A nova conformação leva os rapazes a aceitar moças que não se dedicam exclusivamente às atividades de colona, diante da necessidade de complementar a renda familiar. As moças estão menos disponíveis, devido à oportunidade de trabalho remunerado. Encontram ocupação na cidade como balconistas ou domésticas ou, então, se profissionalizam - por meio do estudo - com a ajuda dos pais. Além disso, há, aparentemente, uma preferência mais concreta e menos idealizada de amor romântico, expressa na expectativa de amor dentro da relação conjugal. Há uma compreensão, entre as mulheres, de que não é preciso sentir afeto e, com o tempo, aprende-se a gostar do marido.

Nem todos os rapazes encontram moças que correspondam ao modelo que qualifiqua um colono. Isso tem favorecido e valorizado moças de comunidades anteriormente menos privilegiadas (economicamente mais pobres ou de credo religioso diferente), que estavam fora do círculo de preferências dos pais. Diante dessa situação, surgem novas parcerias, como por exemplo casamentos interconfessionais (católicos e protestantes) ou interprofissionais (colono e professora), que não deixam de ser apontados como 'problemas' em relação ao que se idealiza como apropriado para a mulher colona nesse contexto e como algo que expõe a risco a identidade do colono: 
Ele foi o único que não quis estudar, tinha dificuldades, e como um tinha que ficar em casa, casou, mas a nora, terminando o segundo grau, quer estudar. Aqui nós precisamos alguém, uma mulher que assume o trabalho. Isso tem que se ajeitar ainda, ou então os dois vão ter que estudar. Vamos dar estudo para o nosso filho também. O casamento não dá certo se um estuda e o outro não. (sexo feminino, 62 anos, casada)

O modelo hierárquico de família persiste, concomitantemente a uma nova situação de transformação. Nos casos peculiares aqui destacados, a autoridade é estruturada dentro de uma visão complementar de papéis de gênero e idade, que são definidos em termos recíprocos. Em contrapartida, os interesses secundários vinculados ao casamento ficaram mais explícitos, a exemplo do casamento de arranjo entre famílias, como relata Ellen Woortmann (1995). As escolhas em função do ganho econômico da mulher passaram a ser incorporadas como parte vantajosa para os homens, embora, no discurso, salientem que predomina a escolha livre, idealizada segundo o modelo de amor romântico. ${ }^{18}$

Observa-se, por parte da família do noivo, que há uma preocupação com a moça escolhida - se esta vai de fato ser fisicamente apta para o trabalho. Para isso, são consideradas a origem dos pais (quando mestiços, geralmente são tidos como não tão trabalhadores) e a aptidão física (não pode ser muito lenta, magra, nem adoentada ou apresentar defeito físico que a impossibilite de erguer peso ou ter filhos, por exemplo). A família da moça, por sua vez, avalia as qualidades morais do pretendente (se é ordeiro, paga as contas, não se excede em discussões ou bebida alcoólica, entre outros aspectos) e fica apreensiva por conseguir preparar a filha para um convívio amistoso com os sogros, pois tem como natural e dada a submissão dela tanto ao marido quanto aos pais dele. Algumas dessas preocupações são verbalizadas no comentário a seguir:

\begin{abstract}
Sim, o colono fica com um filho para cuidar dos pais, continuar a vida de colono. Sim, aqui ficou uma menina, tem que casar com colono, senão não fecha. Pense você: se um rapaz colono casar com uma moça que não é da colônia, como vai ser a vetchaft [tarefas, administração e ou divisão do trabalho na família] de colono? Ou o mais difícil é quando o rapaz casar com uma menina que é de outro lado, de gente que não estão acostumado com a vida de colono. Isso é o mais difícil. Porque vou dizer francamente: o fino, o esfregar, isto que não fecha com a sogra. Mas se é uma moça que conhece o serviço da casa e arruma um rapaz, mesmo que seja da colônia, mas isso fecha melhor, se adapta melhor. A menina, por exemplo, esta que mora comigo, desde criança ela trabalhou no mercado, muitos anos. Aí depois quando a mãe faleceu, ela disse que vinha para casa. Quatro anos demorou para casar com um rapaz que também era colono e eles trabalham juntos como deve ser, mas isto se encontra raramente nos dias de hoje. (sexo masculino, 82 anos, viúvo)
\end{abstract}

A edificação autônoma da casa faz parte do ideal de cada colono. Porém, só os mais 'fortes' conseguem adquiri-la antes do casamento. Geralmente, os recém-casados residem com os pais por algum período (que é razoavelmente longo, cinco a 15 anos, ou indefinidamente, até o falecimento dos patriarcas). Por vezes, a casa é edificada próxima à anterior, no mesmo hoff (pátio), em arquitetura mais moderna, o que exige submissão, salientada em relação à mulher, como se observa no comentário: 
$\mathrm{Eu}$ acho que as mulheres, estas ficam mais submissas... a M. trabalhou, uma mulher que liderava... casou, totalmente dominada pela sogra hoje... Tem que ficar em casa e servir o marido, tem que fazer as coisas para o marido, o serviço. (sexo feminino, 39 anos, casada)

A dominação exercida pelos pais é maior quanto mais próximos forem os pátios, pois, assim, estes acompanham as ações dos filhos, que identificam as diferenças de autonomia com relação à definição de uma administração mais independente:

Isso sim, eu escolhi isso para mim. Foi a maior alegria quando eu podia ir bem separado dos meus pais e dos meus sogros. O importante é que tinha um pedacinho de terra para fazer minha vida, porque eu via esse exemplo da minha irmã, que morava perto do meu pai e perto do sogro dela também. Sempre tem alguém vigiando, os meus cunhados, que moram perto do sogro, lá... Os pais acham que devem ter controle sobre eles. E, para mim, foi muito diferente, resolvi fazer a vida, a nossa vida. Nós casamos, o sogro ajudou a comprar a terra, por isso que eu acho que nós hoje estamos... O sogro comprou e nós tivemos que pagar de volta, mas os que viveram mais perto... cada vez que eles saíam o sogro via e cobrava: 'Isto tu não pode comprar antes que tu paga a minha dívida!' E nós não: nós também, no início, fomos lá cada vez que queria comprar alguma coisa. Tinha que pedir para o sogro, e assim que a gente saiu da dívida, construímos a nossa vida e era opção em participar em tudo. Os outros não deviam porque tinham que trabalhar, trabalhar. (sexo feminino, 39 anos, casada)

As cobranças em relação ao genro em situação inversa, isto é, quando o homem é o escolhido para dividir com o sogro a casa e o trabalho, também não são consideradas tranqüilas, sendo que a mulher (neste caso, a filha) atua como mediadora para evitar atritos:

O pai, como eu falei, se sente dono, tem que continuar mandando, e na verdade tem o genro. Então quando a gente fala, a gente já procura assim apaziguar. Deus o livre, que tem que ter muito papo e outra coisa assim de querer ele não se sentir bem lá... Tem coisas que ele não faz só para poder cobrar isso de nós. É uma coisa muito interessante aquele orgulho, aquela cobrança. (sexo feminino, 33 anos, casada)

Se os noivos são da mesma comunidade, as relações do novo casal são facilitadas e o prestígio de status, de liderança da nova família, passa a sobressair, especialmente se ambos provêm de um bom keim. ${ }^{19} \mathrm{O}$ casamento, que comumente só é oficializado na Igreja, muda os vínculos de identidade dos sujeitos: a mulher passa da submissão aos pais para a submissão ao marido e, se residir na mesma casa, também aos sogros. Perde o seu sobrenome e passa a ser parte da família do marido. A autoridade do marido, entretanto, está articulada a uma visão complementar e recíproca no cotidiano, fazendo parte dos seus deveres ter controle do dinheiro, manter em dia as mensalidades da sociedade e da igreja (oferecer generosas doações em ocasiões de festas), o que lhe dá prestígio, fazendo-o corresponder à imagem pública que se espera de um chefe de família. É pelo sobrenome do marido que se identifica a família.

Está implícito que cabe à mulher o dever de construir essa imagem do representante da família, assumindo uma posição de submissão, aparentando equilíbrio familiar 
em público, pois mulher sem marido não é nada no contexto comunitário. As separações praticamente não acontecem. ${ }^{20}$ Um exemplo das situações em que ocorrem são os casos de alcoolismo do homem, em que a mulher mantém a imagem familiar, assumindo a administração da propriedade com a ajuda dos filhos. Com a mulher calada, aparentemente, o poder continua sendo do homem, mas de fato não é.

Nesse universo, a mulher constrói sua autoridade atrelada à figura de mãe. Em termos simbólicos, religiosos, é invocado um reconhecido louvor a Nossa Senhora, prestigiada por ser mãe. O papel da mulher se completa ao ser mãe; ela não pode apenas ficar sendo uma potencialidade, uma aspirante. A maternidade faz parte da regulação da mulher, que é impedida de ter uma livre circulação, ao mesmo tempo que lhe é dada a oportunidade de exercer autoridade sobre os filhos.

A questão da comida, da higiene, bem dizer, da casa, da roupa, a horta, tem homens que exigem, a mulher primeiro tem que ir junto fazer as coisas da roça, vê que está tudo plantado: milho, feijão, pasto, essas coisas. Tem que estar toda a roça plantada, aí podem ficar em casa e arrumar a horta, arrumar o jardim. Isso eu acho que é coisa de serviço de mulher, fica até em terceiro plano estas coisas de horta. As minhas vizinhas... tem umas que não vão em uma reunião, tem que ir na roça, estão cada dia na roça, mas eu tenho antes coisas na horta do que elas, então não sei, não... Tem flor, essas coisas, é difícil elas plantar flor, então isto é serviço: a casa, lavar roupa, criança, levantar de noite e cuidar dos filhos, até cuidar da saúde deles [maridos], é o caso da mulher fazer um chá para ele, fazer um chimarrão, servir o chimarrão em muitos lugares, é serviço de mulher... Da mulher se exige muito mais. Tu faz o serviço da roça, plantar milho, tem que prestar atenção, mas ao mesmo tempo já está pensando em casa, nos filhos, horário, no pão, como cresceu em casa, se a roupa vai estar limpa, todas estas coisas. (sexo feminino, 39 anos, casada)

A mulher colona, normalmente, tem duas ou até três jornadas de trabalho. Divide o seu tempo entre a roça, os filhos, a casa, as vacas e galinhas, a horta e o jardim. Nessas tarefas, merece pouco auxílio de terceiros ou da tecnologia, ${ }^{21}$ que pode facilitar o trabalho. O capricho da mulher é avaliado pela limpeza dos filhos, da casa (ausência de teia de aranha, pó e capoeira no pátio) e pela horta, que deve ser bonita, com flores e verduras. O homem caprichoso é aquele que tem uma lavoura limpa (sem ervas daninhas), faz boas colheitas e investe o dinheiro, adquirindo tecnologia que aumente $o$ retorno financeiro da propriedade.

O homem é cobrado duplamente: como administrador do dinheiro dentro de casa, sofre pressão do grupo familiar, que quer participar de forma mais igualitária das decisões e da aquisição de bens de consumo. Tanto homens como mulheres disseram que as expectativas de consumo das mulheres estavam além das condições reais de aquisição e da disponibilidade de dinheiro, apontando este como um dos problemas de desentendimento na família.

Eu nunca sabia o que o meu marido fazia com o dinheiro, eu incomodava porque só ele sabia. Aí começou o grupo [de idosos] e eu ia, sempre queria que ele também vinha, então conversava com este, aquele, para ajudar a convencer o meu marido. Vários que foram convidar. Este casal [aponta com a mão os que estavam 
sentados à frente] também falou, então veio uma vez, veio outra, viu como era, agora é ele que ajuda a combinar onde nós vamos. Sabe que muita coisa já mudou, nós temo outra vida e também a gente conversa entre nós. Tem outros casais amigos. Devagar eu fico sabendo o que acontece, o que o meu marido pensa, o que faz com o dinheiro. Aqui a gente foi criado... a mulher... eu não sabia de nada... Hoje, com mais tempo, eu sento na frente da TV, me esforço, porque a gente tem que saber das coisas. Então já estou planejando, reservando o dinheiro. O próximo é para o jornal, eu vou assinar o jornal. A gente não precisa ficar só velha, eu só descobri isto agora. Estou mais feliz que quando estava em casa dia e noite trabalhando. (sexo feminino, 59 anos, casada) $)^{22}$

A outra cobrança é da indústria, do banco, da cooperativa, do modelo econômico mais amplo no qual o homem, como representante da família, interage constantemente. A imagem pública de administrador envolve cobranças que são feitas ao homem e não à mulher; é ele quem responde pelos negócios. ${ }^{23}$ Por exemplo: o cheque correspondente à fatura do leite, que é vendido para a cooperativa, vem em nome do sócio, que é o homem; é ele quem vai retirar o dinheiro que sobrou, após a mulher fazer o rancho no supermercado da própria cooperativa. Mesmo que afirmem que esse dinheiro pode ser retirado igualmente pela mulher, na prática esta é uma tarefa do homem, assim como a assinatura de financiamentos, abertura de conta bancária (a maioria das mulheres não tem conta no banco), operações financeiras que não são detalhadamente conhecidas pelas mulheres. Elas disseram que se interessam por essas questões apenas quando observam que têm dívidas, ou quando o marido demonstra preocupação com a possibilidade de não conseguir quitá-las. A mulher associa o dinheiro ao consumo, ao cuidado com a saúde da família, à manutenção das pessoas e da imagem pública de harmonia da família.

Observamos que algumas mulheres usam estratégias para ter o seu dinheiro extra, em vez de pedir para o marido. Uma delas explicou que, como a produção de leite virou atividade da família e o marido o controla esse dinheiro, ela, juntamente com a nora, tem uma pequena criação de galinhas, e a renda advinda da produção de ovos é utilizada para comprar suprimentos específicos da cozinha (às vezes, censurados pelo homem por serem supérfluos), peças do vestuário (calcinhas, sutiãs etc.) e para oferta de missa.

Temos uma pequena criação de galinhas, não é grande. Agora temos até bastante ovo. Combinamos pontualmente a entrega de ovos, isto se são poucos ou muitos, e isso sempre dá uns cruzeiros. Isso sempre é um dinheiro cada semana - handals kelthe, um pouquinho tem que ter. (sexo feminino, 52 anos, casada)

Entretanto, essa situação é complexa e contraditória, pois observamos que, enquanto algumas mulheres faziam questão de dizer que têm o seu dinheiro para pequenos gastos, outras vão se empregar parcialmente fora de casa, ${ }^{24}$ mas entregam seu dinheiro ao marido. Este mesmo raciocínio não se aplica ao homem, que emprega a remuneração de seu trabalho para garantir a sua imagem de autonomia, independência e status em relação aos outros colonos. Publicamente, só ao homem é permitido jogar, beber e fumar, o que, de acordo com as regras sociais, são transgressões aceitas como parte do lazer. O bom marido idealizado, como podemos perceber nos relatos, é aquele que traz dinheiro para casa, não joga e não bebe: 
Sábado de tarde é o dia de mais serviço para a mulher, mais ocupação. Tem que fazer o que sobrou da semana e já preparar o domingo, deixar a roupa, a casa em dia, a roupa lavada, a comida já meio preparada. Se tu quer ir na missa, na igreja, já tem que adiantar sábado. Os homens, uma grande parte, vai na sociedade, no bolicho, conversam, têm jogo de baralho, bocha ou bolão, jogam por dinheiro, cerveja, já tomam ali. (sexo feminino, 39 anos, casada)

Não sei. Um pouco as relações na família, a gente fica sabendo o que acontece, por exemplo... Tem este homem, K., fica com todo dinheiro. Ele mesmo trabalha fora, mas o filho trabalha só em casa, já com família morando junto, a mulher, ela é gente que trabalha demais, se mata trabalhando e ele gasta dinheiro no jogo. Outro dia fiquei sabendo... perdeu no jogo, tiveram que vender a melhor vaca de leite para cobrir o tufo, então a mulher tem que ficar quieta. (sexo feminino, 51 anos, casada)

Essas transgressões são toleráveis enquanto o homem traz dinheiro para casa e não afeta o sustento da família. Entretanto, o agravamento da situação leva à condenação, que é apontada publicamente como um problema que abala a imagem individual do homem.

Nunca havia imaginado que isso poderia acontecer, pagar com o dinheiro da mulher o que gastou ou gastaram na zona, é uma coisa que eu não sei se poderia aceitar. (sexo feminino, 37 anos, casada)

Ele ia junto nas guria em Santa Rosa... Perdeu tudo: terra, casa, trator, perdeu tudo. Ficou pelado, tudo levando nas schene med [moças bonitas] da zona. (sexo feminino, 70 anos, viúva)

A transição de valores que eles vivem socialmente é complexa, repercutindo numa disputa de papéis de gênero dentro da família. Nessas circunstâncias, a mulher individualmente também quer espaço, fazendo uso do corpo como instrumento de poder para contestar a situação.

A mulher foi criada em segundo plano, né? Submissa a muita coisa... Existe uma briga muito grande entre ser homem, mulher, com relação ao poder. Quem manda, quem não manda em casa. A mulher se vale, por exemplo... é muito comum aqui as mulheres se valer do sexo para mostrar poder. Então elas negam a relação ao homem. Para elas, é um poder, elas sabem que o homem gosta e se valem disto para se impor: 'Eu não dou', isto é muito comum. Tem mulheres que negam sexo aí faz ano... É uma briga de poder, né? É muito comum as brigas. (sexo masculino, 52 anos, casado)

Essa disputa, como sugere o informante, põe em questão a autoridade do homem e se estende por outros contrastes, como o verificado entre trabalho e valor econômico, valor social da pessoa e aquisição de mercadorias de consumo em oferta nos meios de comunicação. A mulher, além do poder sexual, tem vínculos que emergem como suporte para a definição do seu espaço, como podemos observar no comentário a seguir:

Vivendo as situações na família, observo que chega um ponto, os filhos e a mulher ficam de um lado e o pai do outro. Os filhos crescem e ficam do lado da mãe e o pai perde o lugar de chefe. (sexo masculino, 72 anos, casado) 
As mulheres, na atualidade, superam as relações com o espaço doméstico, de parentesco. Observamos que estão engajadas em grupos de discussão nos quais podem compartilhar informações, discutir problemas. Lentamente, despertam para uma auto-afirmação, descobrindo nesta a importância de se sentirem sujeitos com iniciativas e poder de decisão.

A mulher empurra [pressiona], quer mudanças. As que participam um pouco, então, começam aos poucos de ter segurança, mas a maioria ainda está só em casa. $\mathrm{O}$ marido fica sabendo das coisas, não coisas da mulher. Ele fica sabendo o que interessa para ele continuar no mando, não conversa isso com a mulher. São muitas coisas que vão no bolicho por ali [conversas entre homens], nos bar, fica sabendo das coisas que acontecem. Eu também fico sabendo. Os homens, quando a mulher começa de participar, ele sentiu que as coisas estavam mudando, não deixa mais a mulher participar ou então fica sério, de agressão, que elas vão direto denunciar no promotor. (sexo feminino, 39 anos, casada)

Nesse contexto, o modelo de família nuclear passa por uma complexa transformação e algumas contradições são verbalizadas diante de ações que quebram o discurso de igualdade. A mulher colona, em situações isoladas, dá forma a uma nova identidade de contra-resistência; com sabedoria, concilia o espaço doméstico e a participação em atividades fora desse contexto, aumentando a integração com outros vínculos sociais.

\section{Envelhecimento, Organização da Vida e Participação da Mulher}

A vida, como espaço de sociabilidade na conformação desse grupo de colonos, passa por uma construção de poder muito sutil, em meio a um discurso e um esforço de construção da igualdade social. Os colonos entendem a vida como um dom de Deus, acreditam que foram privilegiados com essa graça, mas ao mesmo tempo parece pouco comum se questionarem sobre o que é a vida. A pergunta a ser feita, para eles, é o que fazer para ter vida, como respondeu um senhor de mais de 80 anos:

Para ter vida, a gente não pode se preocupar por que eu ainda estou aqui. Participar no grupo de idosos, comunidade, cooperativa, ter amigos... Viver é não sobrecarregar a carroça, não se sobrecarregar com o trabalho, das muss [obrigação], é relativo, fazer o que a gente pode fazer. (sexo masculino, 82 anos, viúvo)

A vida, como parte de sociabilidade, é seguir e apoiar as normas comunitárias e as obrigações institucionalizadas por esses colonos como identidade social, sem perder de vista a saúde individual do corpo. São as mulheres as responsáveis pelo cuidado individual no cotidiano da família. As meninas, mesmo crianças, são lentamente iniciadas no cuidado quando aprendem a preparar os alimentos, a cumprir os diferentes rituais de limpeza da casa, do pátio, a plantar hortaliças e flores. A característica da mulher cuidadora vai sendo ensinada pela avó, mãe ou responsável (madrinha, tia), de forma muito peculiar. Assim, a moça (15-18 anos) pode ser 'emprestada', ${ }^{25}$ temporariamente, para prestar serviços mediante uma solicitação de gestante/parturiente da co- 
munidade. Nessa situação, as mulheres não negam ajuda, mesmo achando que não poderiam dispensar a filha devido às tarefas que esta desenvolve em casa; cedem ao pedido, diante da explicação de que também elas podem precisar um dia. Essa é uma forma de a moça conviver com uma nova realidade, aprender a lidar com recém-nascido (e maternidade), com a dinâmica e a transformação que acontecem na chegada de uma criança na família. ${ }^{26}$

A função da mulher como cuidadora tem um papel indispensável para a vida do colono. Eles entendem que um homem, viúvo, com filhos, não pode levar a vida sem contrair novo casamento, pois não teria como cuidar da família. A mulher deve receber solidariedade dos parentes (pai, irmãos) e da vizinhança com relação às atividades da roça. Quando a manutenção financeira estiver assegurada para a viúva e os fillhos, não se indica a necessidade de novo casamento. Em contrapartida, essa é uma preocupação das mães em relação aos filhos homens que não contraíram casamento na idade considerada normal (até 30 anos, no máximo). Elas os acusam de 'solteirões' e se mostram receosas em relação a quem vai cuidar deles, temendo que fiquem perdidos. Já as moças, em número bem mais reduzido em comparação aos homens, são acomodadas no grupo familiar - como, por exemplo, mães solteiras, as consideradas doentes ${ }^{27}$ e algumas que têm um ganho financeiro e mantêm e/ou dividem o seu ganho com a família.

A mulher, como cuidadora, tem o papel de gerir e preservar a vida, em iniciativas tanto individuais quanto coletivas (vizinhança). A sua ação envolve a iniciativa de ampliar os limites do grupo, estabelecer relações, ao passo que os homens se mantêm individuais, mais autoritários, comprometidos com a idéia de estabilidade da propriedade, responsabilidade econômica e política de preservar o nome, assegurar as fronteiras da identidade de colono.

Observamos que as mulheres fazem parte de diferentes espaços coletivos, como o clube do lar (articulados a partir da metade da década de 60 pela Emater), ${ }^{28}$ clube de mães (ligado à Confederação das Mulheres Trabalhadoras), reuniões de saúde, grupos que seguem a segregação sexual, em que discutem a condição individual e social da mulher. A mesma mobilização não existe em relação aos homens; estes são convidados para reuniões esporádicas para discutir a produção econômica da propriedade. Foi extremamente difícil conversar com os homens sobre algum assunto que enfocasse os valores sociais ou as transformações da mulher. Os diálogos espontâneos apontaram para o conteúdo econômico, o lucro, a perda, o sofrimento exigido do corpo e da mente para superar obstáculos como entender as contas, falar português e o esforço sobrehumano de se adaptar à tecnologia, mantendo a autonomia da propriedade familiar.

As mulheres contam com estímulos políticos mais concretos (recentes) de mobilização, a exemplo da aposentadoria rural, um benefício conquistado na década de 90, direito que antes era só assegurado ao homem. Além disso, as mulheres estão experimentando direitos civis de autonomia com relação à locomoção, reivindicando benefícios sociais como os de atenção à saúde.

Eu tenho 83 anos e estou bem. Saio com o grupo de idosos e me sinto até melhor de como era antes. Agora eu estou livre para sair quando tenho vontade, só tenho uns pintinhos e, quando quero sair, cuidam. Moro sozinha. Já fiz o inventário, 
ainda estou recebendo de uma parte de terra que vendi. Agora estou planejando... No próximo ano, tem que fazer a transferência da escritura, acho que com isso vou fazer também do usufruto de onde moro: minha casa e de mais quatro hectares que tenho arrendado. Isso tudo é para os meus filhos não ter que brigar depois por minhas coisas. (sexo feminino, 83 anos, viúva)

Enquanto, de forma muito objetiva, faz verbalmente o 'testamento' dos seus bens de acordo com o seu desejo, sem conflito entre os filhos, a viúva aponta o grupo de idosos como motivação e suporte das iniciativas. Essa é uma perspectiva em processo, que está associada à questão da autonomia financeira da mulher, mas não é acessível a todas. Uma parte mais jovem da população feminina convive, no cotidiano, com outra realidade, como comenta a informante a seguir:

Tem homens que querem levar o CPF para casa porque a mulher di kamt doc net, di kan net in di schtat kome, di comt net in di schtat [ela não vem igual, ela não pode vir à cidade, ela não vem na cidade]. Fa rom net? [Mas por que não?] Ai di mus da heim plaiben di arbait schaffen [Ela precisa ficar em casa, realizando as tarefas]. Se é doente, daí é sério, porque se é doente eu entrego... Mas tem muitas mulheres que não vêm e os homens querem levar junto. Elas só ficam em casa. (sexo feminino, 41 anos, casada)

As viúvas, em diferentes comunidades, têm traçado novos objetivos em parceria ou nos grupos de idosos. Em número, as viúvas superam os viúvos. Em algumas comunidades, as viúvas ${ }^{29}$ representam $25 \%$ da população. Observamos que a mulher não se desvincula do cuidar, de resolver preventivamente os problemas com apoio dos filhos, podendo em algumas situações se vincular em novo matrimônio, sendo esta uma situação nova, incipiente como experiência do grupo social.

Hoje me parece... Os viúvos, as pessoas admitem esta possibilidade de ele casar de novo e às vezes ter filhos, mas ainda é... A relação conflituosa é com os filhos, não é por ele não querer, mas é pelos filhos não aceitar. $O$ jogo principal é o jogo financeiro, econômico. Então, para ele casar, tem que casar com separação de bens. Eles permitem o pai ou a mãe casar de novo, mas com união parcial ou sem comunhão de bens, começar do zero, porque eles não querem repartir o que o pai e a mãe, durante anos, conquistaram, com outro... Eu sei de vários casamentos que houve, mas sem comunhão de bens. (sexo masculino, 52 anos, casado)

Observamos que, entre os colonos, a expectativa média de vida aumentou. Muitos casais festejam cinqüenta anos de casamento, ${ }^{30}$ sessenta anos em alguns casos, sendo o casamento uma data importante. Os rituais de renovação, como bodas de prata (vinte e cinco anos de casados) e bodas de ouro, são cerimônias públicas que reforçam os laços sociais, principalmente entre o grupo de parentesco, ocasiões de reunião de toda a comunidade,

Foi uma festa linda que nós fizemos de bodas para a mãe e o pai. Cada filho deu um pouco e o pai mais um pouco e foi lindo, a mãe feliz, feliz, nem cansou. Tu acredita que tinha cinco padre na celebração da missa? Foi uma coisa da gente não esquecer nunca, uma homenagem que fizeram tão bonita... Acho que, em vida, a mãe e o pai não vão mais ter outro dia igual, e tudo deu bem certo na festa, te conto, uma cerimônia inesquecível. (sexo feminino, 29 anos, casada) 
As mulheres, na fase do envelhecimento, têm iniciativas e desenvolvem ações políticas mais ofensivas em âmbito social, quando comparadas aos homens. Criam oportunidades e sentem-se com coragem de falar dos problemas familiares em grupo; acompanham o que acontece com os jovens, estão informadas sobre os assuntos da saúde. Os homens, de forma isolada, conversam no bar, no boliche, durante o jogo de bocha, em locais fechados, limitados como grupo. Eles não estão articulados em seus interesses e reagem de forma individual, apontando como ameaça ao seu poder qualquer iniciativa de mobilização dentro de uma proposta coletiva, que entendem como conspiração, com desconfiança. A vergonha, o medo de abordar diretamente assuntos como a sexualidade, mesmo a título de informação, é assunto de palestra de interesse da mulher; é delas a responsabilidade de cuidar.

Durante nosso trabalho de campo, acompanhamos várias reuniões entre mulheres vizinhas que semanalmente se reúnem em atividades como jogo de baralho, encontro de trabalho manual e, nas terças-feiras, reservam um espaço para inventar novas atividades, com apreciação de quitutes e troca de receitas. Nesses encontros, discutem-se algumas iniciativas que são implementadas e levadas para reuniões mais amplas (no clube social, na escola) entre mulheres e/ou grupo de idosos. Os homens não fazem parte dessas reuniões das mulheres; ficam isolados, realizando tarefas no seu pátio (pequenos consertos, capina da roça próxima à casa), ou acompanham o plantio e o crescimento da soja, alegando que não têm o menor interesse pelas atividades das mulheres.

Acompanhamos também o esforço de determinada mãe que entendia que sua filha casada deveria participar das reuniões das mulheres. Isso a levou a convidá-la para que fosse integrando-se aos poucos, aprendendo alguns trabalhos que lhe despertassem o interesse de se reunir com as demais. Confidenciou que seu genro é muito trabalhador, mas não apóia o clube do lar; vem de uma família em que o pai era autoritário e nunca permitiu a participação da mulher em uma reunião. A mulher explicou que teve essa liberdade e não poderia deixar de integrar a sua filha em atividades fora de casa, fazê-la participar das reuniões e não só ficar em casa trabalhando, porque isso traz vida, explicando que deste mundo não se leva nada para o céu (estava se referindo a bens materiais e a sua acumulação).

Os encontros dos grupos de idosos também foram apontados como espaço de sociabilidade. Observamos que os idosos constituíram um espaço diferenciado, onde podem se comportar como jovens, se permitir sentimentos que haviam ficado de lado, como a amizade entre os integrantes do grupo e a sua união, que entendem como valores inestimáveis.

Nosso grupo é muito unido. É bonito assim quando alguém tem uma idéia. Isso já sai. Agora o rei e a rainha estão se preparando, vai ter a festa dos idosos no município e vai ser escolhido o rei e a rainha do município para este ano, então todos estamos ajudando a fazer as tarefas, estamos preparando uma surpresa, queremos fazer uma apresentação bonita no dia. (sexo masculino, 74 anos, casado)

Os mais jovens também reconhecem e aprovam as mudanças na vida dos idosos, opinando a respeito: 
Têm vida bonita, ganham, sabes? Aposentadoria, têm vida bonita... (sexo feminino, 47 anos, casada)

A participação no grupo é fundamental para estes que são idosos, como o pai. A gente nota que ele conversa com pessoas que têm a idade dele, no dia do encontro ele volta para casa com um monte de coisa diferente para contar e assim a gente vê em casa, sabe? A solidão é muito grande. A mãe já é falecida faz anos. Como o pai, ele assim tem um monte de coisa que ele não se permite. Tu pensa que ele uma vez ligou a televisão, ele só assiste se nós estamos olhando, o mesmo canal, mesmo se tem outro programa na Rede Vida, isto ele não, só para poder cobrar de nós. É muito interessante, né? Aquele orgulho... Ele se impõe com a idade o respeito. As pessoas não se preparam para esta idade e o relacionamento com os filhos. Acham que simplesmente têm que continuar mandando, precisam de poder e hoje já é diferente. Deviam falar mais disso no grupo de idosos. Eu vejo que um pouco ele já melhorou, porque eu sinto que ele gosta se eu troco o canal para a Rede Vida. (sexo feminino, 34 anos, casada)

A mãe... Hoje eu estou sentindo que ela está mais feliz do que quando no tempo em que estava em casa, muito mais feliz. Ela sai, dança com meu pai... O meu pai nunca dançou, hoje participa do grupo de idosos. Tu é para ver como meu pai dança, canta, nós nunca ouvia o pai cantar durante o tempo que eu estava em casa. Hoje canta, estão muito mais feliz. Eu acho que os filhos são um atropelo na vida, às vezes sempre uma tropa de gurias ao redor, a gritaria, amigos, discutem... Acho que hoje eles são mais feliz e mesmo hoje, dormindo separado, têm mais afetividade, estão mais felizes que no tempo em que tinham mais potência, força física. (sexo feminino, 39 anos, casada)

Os grupos de idosos têm uma mobilização muito forte nas comunidades, ${ }^{31}$ estão descobrindo e mostrando um outro espaço de vida entre as pessoas em fase de envelhecimento e que, até então, não se permitiam. Fazem reuniões mensais coletivas, discutem problemas que têm com os filhos, realizam promoções sociais entre comunidades, apóiam iniciativas dos jovens, fazem com que sua mobilização traga uma nova perspectiva de vida para os demais membros da sociedade.

Esse processo, de acordo com uma informante, intensificou-se com a aposentadoria rural para as mulheres, pois permitiu a elas também terem o seu dinheiro, coisa que poucas tiveram durante a vida como colonas. Além disso, criou expectativas para se aposentar, ter seu salário e poder tomar algumas iniciativas como fazer uma pequena viagem, ir à casa dos filhos, e não só trabalhar.

Entretanto, a aposentadoria do idoso, em algumas situações, também representa o sustento de toda a família. Alguns jovens se sentem no direito de reivindicar para si o dinheiro, na argumentação de que cuidam do idoso, situação denunciada pelos demais idosos do grupo que conhecem a realidade de cada um, pois planejam entre si pequenos passeios, visitas a lugares turísticos ou mesmo a outros grupos de idosos. Dizendo que cada um pode fazer uso do dinheiro como quiser, protestam, pois não acham certo que aqueles que não estão aposentados o usurpem, em vez de trabalharem e ganharem o seu sustento dignamente. 
O filho dela não quer trabalhar, vive da aposentadoria da mãe. Outro dia, a T. viu no banco, ele leva a L. buscar a aposentadoria, fica do lado de fora e quando volta na porta fica com todo dinheiro, cinco reais diz que viu ele deixar para ela. Isso é o fim, fazer isso com a mãe não é certo. (sexo feminino, 73 anos, casada)

A grande maioria dos idosos compreende que a aposentadoria é de quem a recebe, e não dos filhos; estes devem trabalhar, como os idosos já fizeram; se os idosos querem ajudar, podem fazê-lo de forma que beneficie todos os filhos, como explicou uma aposentada, de forma orgulhosa:

No Natal, comprei um presentinho para cada um dos meus filhos. Aprendemos a fazer um arranjo e eu consegui fazer um para cada filho. Eu acho que nós temos que dar igual para cada um. Os meus todos são casados, mas eu fiz questão de dar para todos eles. Agora tenho tempo e vou inventando coisas, não vou parar, até não poder mais. (sexo feminino, 74 anos, casada)

Os idosos vão criando novas formas de sociabilidade, reinventando valores que fortificam os laços dentro das famílias e da comunidade, permitindo novas formas de relacionamento. Observamos, nesse grupo social, que as pessoas na fase do envelhecimento são as que dispõem de mais tempo para discutir problemas do cotidiano, empreender iniciativas de intervenção de acordo com os interesses comunitários, conciliar grupos com interesses políticos opostos. Diversos idosos declararam ter uma mensagem de trabalho e ação para deixar aos jovens, de motivação para que dêem valor aos seus costumes, como as práticas religiosas, o convívio social, demonstrando isso em pequenos exemplos, como a dança da polonesa no início de cada reunião dançante ou baile.

\section{NOTAS}

1 O termo 'colono' é utilizado corriqueiramente pelos agricultores para nomear a si mesmos, o que não pode nos levar a generalizações. No sentido em que o empregam, fica evidente que expressa um sentimento de igualdade dentro daquele espaço social. Há, entretanto, diferentes tipos: os que têm terra, os que não têm e trabalham como arrendatários (na opinião deles, são muito diferentes dos que invadem propriedades). De acordo com a nossa observação, a identidade que expressam se relaciona à forma de organização econômica, familiar, participação comunitária (igreja, escola, clube social) e trabalho com a terra, da qual depende o sustento da família, e lhes dá credenciais para se enquadrar como colonos (foram taxativos ao afirmar que, para serem colonos, não podem ter outra fonte de renda).

2 A aposentadoria rural anterior à década de 90 só beneficiava os homens.

3 O município de Santo Cristo foi emancipado pela Lei Estadual no 2.602, de 28 de janeiro de 1955. Inicialmente, o núcleo Santo Cristo integrava o 5o Distrito de Santo Ângelo; em 1924, passou a ser sede do 10ํDistrito; em 1931, tornou-se o 4응 Distrito de Santa Rosa; e somente em 1955 ocorreu a sua emancipação políticoadministrativa. 
4 Conforme os dados do IBGE, na década de 70 havia 15.076 habitantes, sendo que 1.914 residiam na área urbana e 13.162 no meio rural. Os dados comparativos por década podem ser obtidos em Heck (1994).

5 Cada comunidade rural é composta por 60 a 120 famílias, que residem em casas individuais.

6 A Emater recebe fomento financeiro para prestar assistência técnica e é vinculada à Secretaria de Agricultura do Estado do Rio Grande do Sul.

7 As salas de ordenha têm piso e paredes em cerâmica. As vacas são ordenhadas em celas individuais, que precisam ser lavadas e pintadas (com cal) periodicamente. $\mathrm{O}$ piso precisa permanecer lavado e limpo em cada turno. A ordenha das vacas é feita em dois horários: pela manhã e ao entardecer. Os tarros, onde é armazenado o leite, também precisam de limpeza rigorosa, assim como o resfriador, local que mantém acondicionado o leite na propriedade. O caminhão leiteiro recolhe a produção de 24 em 24 horas.

8 Os homens se empregam na construção civil e em trabalhos urbanos sem qualificação específica. Observamos que, entre as comunidades rurais próximas à sede, de seis a dez homens se deslocam diariamente para trabalhar no meio urbano; as mulheres e os filhos assumem o trabalho na propriedade rural.

9 Existe uma hipótese, ainda não pesquisada quantitativamente, mas perceptível no discurso dos colonos e que assinala o empobrecimento deles nas últimas três décadas. No final da década de 60 e no início da de 70, deslocam-se para as novas frentes de colonização em Santa Catarina e Paraná, vendendo a terra e adquirindo outra de menor custo e maior área (coberta de mata). Na década de 80, migram para o Pará e o Maranhão, sendo que alguns retornam. A maioria submete-se a condições de vida piores que as anteriores. E, na década de 90, há uma valorização da terra no país. Além disso, a distribuição da herança fragmenta os lotes. O capital que possuem não permite a aquisição de terra, então migram para a área urbana. Com o dinheiro da venda da propriedade, conseguem comprar um terreno e vão para a região do Vale dos Sinos, área de indústria coureiro-calçadista. Alguns ainda arriscam ir para o Paraguai, mesmo sabendo que lá não têm direito de propriedade, somente o título de posse da terra.

10 Das associações voltadas para a perspectiva produtiva, hoje permanecem ativas somente a Cooperativa Mista São Luiz, a Cooperativa Tritícola Santa Rosa (CotriRosa), cinco Associações de Produtores de Suínos (Apsats), o que corresponde a aproximadamente duzentos colonos, e a Asca, uma cooperativa de consumo (troca e venda de gêneros alimentícios).

11 Essa experiência teve início em conjunto com a enfermeira Dóris Nonnemacher, agentes da saúde e 11 idosos da comunidade de Bom Fim. A partir dela, a formação de grupos de idosos em comunidade rurais se multiplicou.

12 O catolicismo é a religião predominante (90\%), e os $10 \%$ restantes da população são evangélicos luteranos e membros da Assembléia de Deus. Todas as linhas (núcleos rurais) do município têm prédios da Igreja católica e cemitérios. Em duas linhas, 
observamos que o cemitério é interconfessional, mas as igrejas funcionam em prédios independentes.

13 A cuca é um prato típico da culinária alemã, preparado e servido em datas festivas. Consiste de uma massa de farinha de trigo doce recheada com schimier de framboesa, requeijão, uva, mamão e pêssego, entre outros ingredientes. 70 , esse número começou a diminuir, estando hoje por volta de dois a três filhos. As formas de anticoncepção são assunto abordado no curso de noivos. Entretanto, com o aumento de jovens engravidando em idade precoce, o assunto passou a ser enfocado também na preparação da crisma (um dos sacramentos que o jovem recebe na Igreja Católica durante a adolescência).

16 Na região, existem apenas instituições particulares de ensino superior. A instituição pública mais próxima fica a 300 quilômetros. A formação profissional de nível técnico não existe de forma contínua. A maioria dos filhos de colonos que estudam desiste da vida agrícola, fazendo esta opção bem antes de terminar o curso superior.

17 A formação religiosa (inclui curso superior de filosofia) exige um custo financeiro que não é acessível para um colono. A renda familiar é baixa, não perfazendo um salário mínimo por pessoa/mês. O dinheiro é vinculado à safra e não constitui um rendimento mensal. Numa situação em que foi exposta a contabilidade da família, as despesas com o estudo de um filho absorviam $3 / 4$ da renda obtida mensalmente com o leite, sendo que três trabalhavam em casa e dividiam os $25 \%$ restantes em valor bruto.

18 Semelhante ao que diz Giddens (1993), o amor romântico, entre os colonos, se assemelha ao que foi observado entre os camponeses da França e da Alemanha do século XVII, em que o beijo, a carícia e outras formas de afeição física associadas ao sexo eram raramente expostas pelos casais.

19 O keim, categoria descrita por Ellen Woortmann (1995), relaciona-se à reprodução e à observância de valores tradicionais. Avaliam-se as pessoas como derivadas de keim bom ou ruim; entre estas, ele cita as condutas morais negativas que não devem ser levadas adiante pelas pessoas.

20 Durante a coleta de dados, criaram-se vínculos com várias mulheres que relatavam problemas de relacionamento com os maridos. O impressionante era a agressividade entre casais, a violência autoritária, calada, sem denúncia, que recaía sobre as mulheres. Elas buscavam soluções com o padre, com familiares; não faziam denúncia pública contra os maridos.

21 A ordenha mecânica das vacas é a tecnologia mais inovadora que estava sendo adotada em algumas propriedades. A maioria dos colonos continuava com a prática de ordenha manual, tarefa que ocupava as mulheres e as crianças.

22 Este depoimento foi dado numa festa, na presença do esposo e de um casal de amigos da depoente. 
23 Também é o homem que responde diante do Conselho Tutelar, do promotor, pela ação judicial de prorrogação da dívida agrícola com o banco, pela dívida direta com o comerciante. Estes foram alguns problemas apontados por homens que se diziam preocupados em superar situações desse tipo.

24 A complementação da renda é crescente em atividades fora de casa, em que as mulheres vão se empregar em pequenas agroindústrias ou atividades de educação, saúde e cargos de lideranças (a presidente do sindicato de trabalhadores rurais é mulher e vereadora).

25 A autorização quem dá é a mãe e, se envolve salário, também é acertado por ela. Não nos deixaram claro qual é esse valor e nem se a cobrança sempre envolve dinheiro.

26 Essa é uma referência que dão quando buscam emprego de doméstica. Conforme o desempenho, têm melhores referências. Elas referem-se a esses acompanhamentos a puérperas não como emprego, mas períodos em que trabalharam em tal família (geralmente de dois a três meses). Também observamos que desenvolvem vínculo de afetividade e amizade com crianças e casais com os quais conviveram.

27 Essas doenças nem sempre são casos reconhecidos por um médico, mas os demais a caracterizam como net kans richtig (não bem certo), sendo que esta pessoa recebe um tratamento de doente por parte do grupo. Acompanhamos dois casos de pessoas que fizeram perícia médica, para requisitar aposentadoria por invalidez, e não tiveram parecer clínico de doença confirmado. Para a comunidade, eram casos inquestionáveis de doença, pessoas tratadas como 'doentes da cabeça', 'sem juízo'.

28 A Empresa de Assistência Técnica e Extensão Rural é um órgão do estado e tem um escritório em cada município do Rio Grande do Sul. A equipe é composta por, pelo menos, um engenheiro agrônomo, uma extensionista e um técnico agrícola.

29 Essa observação foi relatada por uma viúva que fez questão de me levar à casa de todos os filhos e, por último, conduziu-me ao cemitério, onde está enterrado o marido. Lá, relatou como organizou sua vida após o falecimento do marido e observou que organizam os túmulos aos pares, já reservando espaço para o pessoa que permanece viva, seguindo uma ordem igual à da festa de casamento.

30 Essas datas são festivas somente se os dois parceiros do casamento estão vivos; se um deles é falecido, não há comemoração da data.

31 Estavam em atividade 28 grupos de idosos, das 35 comunidades que compõem o município. Contavam com acompanhamento da Secretaria da Saúde e Ação Social.

\section{Referências Bibliográficas}

GEERTZ, C. A Interpretação das Culturas. Rio de Janeiro: Guanabara Koogan, 1989.

GIDDENS, E. A Transformação da Intimidade. São Paulo: Unesp, 1993. 
GROSSI, M. P. Jeito de freira: estudo antropológico sobre a vocação religiosa feminina. Cadernos de Pesquisa, 73:48-58, 1990.

EMATER, Escritório Local de Santo Cristo/RS. Levantamento de Dados e Informações. Santo Cristo, 1992. (Mimeo.)

HECK, R. M. Suicídio, um Grito sem Eco: contexto social de Santo Cristo. Pelotas: UFPel, 1994.

HECK, R. M. Contexto Sociocultural dos Suicídios de Colonos Alemães: um estudo interdisciplinar para a enfermagem, 2000.Tese de Doutorado, Florianópolis: Programa de Pós-Graduação de Enfermagem da Universidade Federal de Santa Catarina.

INSTITUTO BRASILEIRO DE GEOGRAFIA E ESTATÍSTICA (IBGE). Sinopse Preliminar do Censo Demográfico - 1996. Rio de Janeiro: IBGE, 1996.

KALACHE, A. et al. O envelhecimento da população mundial: um desafio novo. Revista de Saúde Pública, 21(3):200, 1997.

TAVARES, E. L. \& ANJOS, L. A. Perfil antropométrico da população idosa brasileira: resultados da Pesquisa Nacional sobre Saúde e Nutrição. Cadernos de Saúde Pública, 15(4):759-768, 1999.

VELASQUEZ, M. D. et al. As trajetórias de vida dos cuidadores principais. In: KAESCH, U. M. (Org.) Envelhecimento como Dependência: revelando cuidadores. São Paulo: Edusc, 1989.

WOORTMANN, E. Herdeiros, Parentes e Compadres: colonos do Sul e sitiantes do Nordeste. São Paulo, Brasília: Hucitec, Ed. UnB, 1995. 


\title{
Nervoso e Experiência de Fragilização: narrativas de mulheres idosas
}

\author{
Paulo César Alves
}

Na literatura gerontológica, a velhice é usualmente concebida como um período de ajustamento às mudanças fisiológicas provocadas pela força física cada vez menor, às transformações físicas no corpo, à incapacidade de procriação, à morte do cônjuge, ao abandono do lar pelos filhos.

Erikson, Erikson \& Kivnick (1986), por exemplo, caracterizam a velhice como, necessariamente, um tempo de abdicação. Os mesmos autores também consideram que na velhice, devido às características biológicas próprias ao seu gênero e/ou à posição sociocultural em que está inserida, a mulher teria maior probabilidade de entrar em crise, principalmente no que concerne à concepção que ela tem de si mesma, ligada às multideterminações que até então sustentavam a sua identidade (Lock, 1993). A velhice, portanto, é identificada como um período de particular fragilidade no curso da vida das mulheres. Mas esses autores observam ainda que as mulheres idosas tendem a questionar a sua situação feminina, em função de um conjunto de elementos ligados à sua trajetória singular, aos seus projetos iniciais, ao lugar que ocupam no mundo social. ${ }^{1}$

Tendo em vista a importância atribuída à idéia de fragilização no tocante a uma caracterização da velhice, torna-se necessário que as ciências sociais se detenham mais cuidadosamente no significado desse termo. A idéia de fragilização está revestida de significados variados, dependendo em grande medida do uso que lhe é dado pelas diferentes disciplinas.

Contudo, apesar das diversas modalidades interpretativas atribuídas a essa noção, parece existir um certo consenso entre os pesquisadores sobre associar fragilização com vulnerabilidade. Sendo fragilidade ligada ao que é quebradiço, pouco vigoroso ou débil, a idéia de vulnerabilidade refere-se à qualidade ou ao estado de alguém que pode ser atacado ou ferido e, portanto, pressupõe uma situação ou acontecimento capaz de perturbar o estado físico ou mental de alguém. Assim, pode-se observar que o significado de fragilidade usualmente refere-se a eventos que são tidos como provocadores de determinadas desordens ou desajustamentos nos indivíduos. Nesse aspecto, não se leva em devida consideração que vulnerabilidade, se pressupõe o efeito nos indivíduos, diz respeito também à maneira pela qual respondemos às condições potencialmente 'fragilizadoras' do nosso meio e, portanto, depende largamente do significado que é dado aos eventos. 
A idéia de vulnerabilidade pressupõe o que podemos chamar de 'qualidade do evento', isto é, o aspecto circunstancial do acontecimento, as situações nas quais os indivíduos socialmente vivenciam e interpretam determinados acontecimentos tidos como vulneráveis, associando-os ou não a outras situações ou contextos da sua vida. A qualidade do evento, portanto, depende da especificidade da resposta social e individual que é dada a ele. Nesse aspecto, a qualidade do evento nos remete tanto a elementos tidos como 'subjetivos' (percepções, interpretações, sentimentos) quanto a 'objetivos', a experiências cotidianas e estratégias socialmente aceitas para melhor lidar com acontecimentos. Assim, se determinados eventos podem desencadear uma experiência aflitiva, isso não prova que tal experiência derive exclusivamente desses acontecimentos.

Há que se considerar que a severidade do evento (freqüência, intensidade e duração) é sempre passível de ser relativizada ou vista em suas circunstâncias, pois uma série de aspectos biopsicossociais que compõem uma determinada vivência são elementos essenciais para se pensar a qualidade do evento. Portanto, para melhor compreendermos o significado de fragilização - ou, antes, de processo de fragilização - torna-se necessário observar que, na análise da qualidade de um evento, deve-se levar em devida consideração a presença de um conjunto de elementos, tais como self, intersubjetividade, contexto e situação social em que se encontra esse 'eu'. É no contexto de uma trajetória - de uma história pessoal de vida - que eventos pontuais ganham sentido para o sujeito.

O conceito de experiência nos parece essencial para se compreender o de processo de fragilização, pois nos remete diretamente à dimensão vivida da cultura, de símbolos, crenças, regras e códigos que supostamente regem os comportamentos. Um primeiro ponto nessa direção é reconhecer a preeminência da esfera do fazer e agir sobre o pensamento e a reflexão. Assim, em vez de situarmos a análise no universo já constituído de representações ou objetificações, a análise da experiência nos conduz a problematizar o processo em que a vivência de algo se constitui e ganha expressão (Csordas, 1990). Ao incorporar o conceito de experiência aos estudos em antropologia da saúde, a atenção é deslocada da doença ou aflição como fato (seja dado empírico ou signo) para o curso da doença como experiência. ${ }^{2}$

Várias questões importantes podem ser relacionadas se considerarmos a idéia de fragilidade do ponto de vista da experiência. Como as mulheres dão significados às experiências tidas como 'fragilizadoras' da condição feminina? Como elas, sendo portadoras de problemas relativos à saúde mental, vivenciam momentos críticos e reagem a eles? Que significados as mulheres idosas atribuem às suas aflições mentais? Em que sentido elas se sentem fragilizadas e impotentes para administrar suas vidas, levandose em conta as situações cotidianas de um bairro de classe trabalhadora?

Inseridos na perspectiva sociológica e antropológica da saúde, propomos aqui analisar o significado de experiências potencialmente 'fragilizadoras', a 'doença mental' em mulheres idosas e nervosas pertencentes a uma comunidade urbana de baixa renda em Salvador. Mais especificamente, pretendemos caracterizar o discurso (narrativa) que as mulheres idosas, definidas por elas mesmas e pela comunidade local como 'nervosas', produzem para interpretar as experiências consideradas como 'fragilizadoras' nas suas trajetórias de vida. 
A discussão está fundamentada em dados produzidos por um conjunto de pesquisas realizadas por integrantes do Núcleo de Estudos em Ciências Sociais, Ambiente e Saúde (Ecsas) da Universidade Federal da Bahia, de 1993 a 1997. O principal trabalho de pesquisa, no que se refere à nossa temática específica, intitulou-se Saúde Mental e Processos de Fragilização na Trajetória de Mulheres de Classe Trabalhadora Urbana. ${ }^{3}$ O objetivo dessa pesquisa foi identificar e caracterizar como as mulheres de baixa renda, moradoras em um bairro de classe trabalhadora de Salvador (Nordeste de Amaralina), percebem e vivenciam alguns dos principais processos de fragilização relacionados à saúde mental e como as redes sociais de suporte disponíveis na localidade as ajudam a lidar com os eventos e processos 'fragilizadores'.

Inicialmente, faremos uma rápida revisão crítica da literatura sobre mulher e saúde mental, com o objetivo de introduzir a nossa problemática: os conceitos de experiência e narrativa como elementos essenciais para a compreensão do significado de mulheres idosas e 'nervosas'. Após identificar brevemente os signos e significados do nervoso no Nordeste de Amaralina, apresentaremos os fundamentos metodológicos da pesquisa que serviu de alicerce para este artigo. Em seguida, analisaremos alguns aspectos característicos das narrativas produzidas por mulheres idosas e nervosas.

\section{Saúde Mental, Gênero Feminino e Narrativa}

Nos últimos trinta anos, aproximadamente, tem havido uma crescente atenção por parte dos cientistas sociais ao estudo das relações entre mulher e saúde mental, como atestam os trabalhos, entre outros, de Chesler (1972), Ehrenreich \& English (1978), Gove (1984), Showalter (1987), Miles (1988), Ripa (1990), Ussher (1991) e Russel (1995). Mesmo assim, a natureza dessa associação parece não estar ainda suficientemente explicada, e os resultados alcançados pelas pesquisas são amplamente discutidos.

Tendo em vista a complexa relação entre mulher e saúde mental, é conveniente que comecemos a nossa análise levando em devida consideração a natureza e o significado dessa associação. Em primeiro lugar, não devemos esquecer que grande parte dos trabalhos que lidam com essa relação parte dos dados fornecidos pela epidemiologia. A abordagem epidemiológica aponta para as diferenças entre as taxas de desordens mentais conforme o gênero. Trabalhos realizados nessa área, principalmente em zonas urbanas de baixa renda, observam maior prevalência de morbidade psiquiátrica entre as mulheres (Coutinho, 1974; Memminki, 1974; Choiton et al., 1976; Almeida Filho e Rouquayrol, 1982; Mari, 1987; Reichenheim \& Harpham, 1991). Um resultado comum dessas pesquisas refere-se ao fato de que as mulheres são as que mais sofrem dos chamados distúrbios afetivos, desordens neuróticas, principalmente os afetos disfóricos ou depressivos (Weissman \& Klerman, 1977; Gove, 1984).

É importante chamar a atenção, contudo, para o fato de que alguns estudos tradicionalmente conhecidos como 'feministas' argumentam que as medições epidemiológicas são superestimadas - e que seus resultados, portanto, são artificiais -, uma vez que, comparadas aos homens, as mulheres têm maior número de sintomas (isto 
é, são mais perceptivas no tocante a suas emoções), tendem a reportá-los mais facilmente e buscam mais rapidamente um tratamento (Dohrenwend \& Dohrenwend, 1977; Scambler, Scambler \& Craig, 1981; Sartoris \& Rapella, 1985; Rogers, Pilgrim \& Lacey, 1993).

Não há dúvida de que os achados epidemiológicos são muitas vezes esclarecedores para um conjunto de problemas apresentados pelos pesquisadores e formuladores de políticas de saúde. Mas em que aspecto a epidemiologia identifica e discrimina a associação entre mulher e saúde? Até que ponto a abordagem epidemiológica pode fundamentar uma perspectiva socioantropológica? Desnecessário é afirmar a complexidade dessas questões, e não nos cabe aqui discuti-las. Contudo, é importante observar que, para o campo socioantropológico, a abordagem epidemiológica é insuficiente ao analisar as relações entre saúde mental e processo de fragilização.

Vejamos alguns dos pressupostos da análise epidemiológica. O primeiro deles é a noção de 'fator de risco', um conceito que parece central nesse campo (Ayres, 1997). Para a epidemiologia, risco é usualmente definido como a probabilidade de que indivíduos ou grupos sociais de uma determinada população possam desenvolver, em certo período de tempo, um dado evento relacionado à saúde. Trata-se de um conceito que está fundamentado em teorias probabilísticas e de causalidade voltadas para explicar a correlação, estabelecida por medidas de 'co-incidência', entre uma classe particular de eventos, ou um conjunto deles, e uma determinada desordem ou desajustamento físico ou mental. Tal noção limita-se a quantificar correlações e incertezas, abstendo-se de investigar o processo pelo qual um determinado episódio é interpretado pelos atores sociais. Assim, a depressão entre as mulheres é associada a determinados eventos, situações ou momentos definidos previamente como estressantes.

Há aqui algumas questões fundamentais. Em primeiro lugar, é importante observar que, para estabelecer tal associação, é necessário identificar e discriminar o conteúdo concreto dos fenômenos tidos como estressantes. Há, portanto, um processo de 'objetivação'. Não apenas se objetivam os eventos como também se objetiva o significado de depressão, o qual é usualmente entendido na concepção biomédica (psiquiátrica) do termo. Trata-se, portanto, de uma dupla objetivação. A noção de 'fator de risco' pressupõe também uma determinação causal. Os eventos identificados são considerados como causadores dos distúrbios mentais entre as mulheres. Por último, procurando expressar a correlação saúde-mulher em termos quantitativos, a análise epidemiológica tende a reduzi-la a uma hierarquização de variáveis. Assim, apenas duas grandes especificidades são levadas em consideração: um conceito operacionalizado de evento (entendido, muitas vezes, como uma questão etiológica) e a presença de uma desordem, ou um conjunto de desordens, provocada pelo evento.

Ao procurarem identificar e discriminar a associação entre mulher e saúde, os estudos desenvolvidos no âmbito das ciências sociais fundamentaram-se, grosso modo, em duas grandes linhas de argumento. A primeira, mais 'biologicista', refere-se aos estudos que defendem a tese de que as mulheres são mais susceptíveis a problemas mentais do que os homens, devido às condições intrínsecas à natureza feminina, tais como aquelas decorrentes das questões reprodutivas (tensão pré-menstrual, uso de anticoncepcionais, distúrbios do pós-parto, menopausa). 
O famoso trabalho de William Stephens (1962), The Oedipus Complex, ao discutir a 'ansiedade de castração' e o 'tabu menstrual', pode de certa forma ser enquadrado nessa linha. Tendo em vista a prioridade atribuída a fatores biológicos, 'objetivos', o tratamento dos distúrbios próprios das mulheres é visto, em última instância, como uma questão médica, farmacológica ou psiquiátrica.

Essa concepção tem motivado determinadas considerações críticas. Chesler (1972) vê nesse tipo de argumento uma certa ‘criação' da medicina e aponta, entre outros aspectos, para o interesse da indústria farmacêutica em manter tal concepção. Fazendo um balanço da perspectiva psiquiátrica sobre a mulher, Russel (1995) observa que os 'danos' causados por essa disciplina, ao rotular e manipular inadequadamente alguns problemas femininos, têm sido maiores do que os benefícios legados. A autora argumenta que a medicina, preocupada em catalogar e rotular certos comportamentos femininos como patológicos, tem se descuidado da avaliação de uma série de comportamentos masculinos que igualmente poderiam ser julgados, dentro dos mesmos critérios classificatórios, como patológicos.

Outra importante linha de argumento, de caráter mais ‘sociológico', diz respeito àqueles estudos que atribuem um grau maior de importância a determinações ligadas à estrutura social, bem como aos significados coletivos de que se revestem os fatores de riscos usualmente apontados pela epidemiologia. São concepções que procuram compreender a relação entre ‘distúrbio psiquiátrico' e mulher por meio do papel por ela desempenhado e do lugar por ela ocupado na sociedade, isto é, sua posição de subordinação, seu status desvantajoso, sua falta de poder, maior dependência e menor autoestima. Tais fatores ou processos levariam as mulheres a vivenciar os eventos de forma distinta da dos homens, tornando-as mais vulneráveis (Oakley, 1974; Rosenberg, 1984).

$\mathrm{O}$ argumento predominante, portanto, é o de que a vulnerabilidade da mulher a desordens neuróticas é, em última instância, uma questão de discriminação e exclusão social. Assim, literatura sobre gênero tem observado que as mulheres apresentam taxas de desemprego mais altas que os homens, e que as da classe trabalhadora que desempenham o papel de chefe de família - um fenômeno crescente no Terceiro Mundo (Tinker \& Bramsen, 1977; Barroso, 1978; Neupert, 1988; Oliveira, 1992; Goldani, 1994) têm menos acesso a recursos e são mais dependentes do 'setor informal' da economia do que os chefes de família do sexo masculino (Bolles, 1985; Jelin, 1994). Tal orientação teórica aponta também, pelo menos indiretamente, para um possível decréscimo das taxas de depressão no mundo feminino, à medida que as mulheres passam a ser menos discriminadas socialmente. Nessa linha de argumento temos, por exemplo, os trabalhos de Murphy (1986), Klerman (1989) e Russel (1995), os quais observam que a crescente participação da mulher na força de trabalho e as mudanças do seu comportamento em direção a maior individualização e autonomia constituem fatores importantes para a redução dessas taxas.

Um exemplo significativo da interpretação 'sociologista' referente à relação entre mulheres deprimidas e situação ou contexto feminino pode ser encontrada em dois trabalhos realizados na Inglaterra por Brown \& Harris (1978) e por Miles (1988). Sem deixar de considerar os possíveis fatores biológicos específicos do gênero feminino, Brown \& Harris chamam a atenção para os 'agentes provocadores' da depressão, isto 
é, para os eventos adversos na vida de um indivíduo, tal como morte de parentes, doenças, rompimento de relações íntimas, acidentes. Para esses autores, a depressão nas mulheres está relacionada a determinados acontecimentos, tais como a perda da mãe antes dos 11 anos de idade, a presença em casa de três ou mais crianças com menos de 14 anos, a ausência de relação confidencial, principalmente com o marido, e a perda parcial ou completa do trabalho.

Miles igualmente aponta para outros aspectos problemáticos da vida das mulheres diagnosticados como depressivos: casamentos insatisfatórios, traumas, problemas de ordem reprodutiva, relações familiares insatisfatórias (família de origem), eventos vitais adversos ou dificuldades severas, como o cuidado com parentes doentes ou velhos e o padecimento de doenças físicas crônicas. A autora acredita que a possibilidade de melhora para essas mulheres envolveria mudanças profundas nas suas vidas, como divórcio, separação, mudança de casa, obtenção de um trabalho satisfatório e novas relações sociais. Um aspecto interessante para o qual chamamos a atenção nesses dois estudos, principalmente no de Miles, é que eles não se limitam apenas a enumerar e classificar cuidadosamente os 'agentes provocadores', mas se preocupam em apresentar as representações que as mulheres deprimidas atribuem aos eventos.

Tanto a interpretação que chamamos de 'sociologista' quanto a 'biologicista' tendem a enfatizar o caráter objetivo da realidade social, isto é, identificam e discriminam objetivamente fenômenos causadores de 'estresse'. Para uma vertente, são de ordem fisiológica ou biopsíquica; para a outra, uma estrutura material de relações sociais ou sistemas de idéias, valores ou modelos. Sejam estruturas biológicas ou socioculturais, ambas são vistas como fenômenos exteriores (tomados como algo a priori) que se impõem aos indivíduos, estabelecendo limites e possibilidades para as suas ações. Nesse aspecto, ambas as interpretações terminam por sustentar uma visão dicotomizada do fenômeno social.

A objetivação pressupõe a existência de um sujeito que objetifica, estabelecendo, assim, 'duas' ordens de realidade: o objeto, identificado como os entes que estão 'fora' das consciências individuais; e o sujeito que os apreende. Basear-se nesse pressuposto para estabelecer o ponto de partida para a análise socioantropológica é problemático. A questão que se apresenta é: como o objeto está na consciência? A resposta usualmente dada a essa questão argumenta que é pela representação que concebemos o mundo e que por meio dela nos orientamos e guiamos as nossas ações.

Para entender as relações entre mulher e saúde mental, é importante que o pesquisador se atenha de forma mais cuidadosa às vivências ou trajetórias de vida que levam os indivíduos a se sentir fragilizados e/ou impotentes diante das condições que lhes são dadas. Tomar como ponto de partida a idéia de que o problema mental é resultante de uma interação complexa de experiências que se desenvolvem ao longo de uma trajetória de vida exige do pesquisador atenção ao processo pelo qual os indivíduos dão sentido e respondem às suas condições e às situações dadas. Mas afirmar a importância da significação atribuída a eventos estressantes (qualidade do evento) não equivale a dizer que devemos nos ater exclusivamente às 'representações' individuais sobre esses eventos. 
Os estudos que tomam o discurso dos indivíduos como porta de entrada para o universo de significações têm, sem dúvida, ampliado o nosso entendimento das matrizes culturais sobre as quais se erguem os conjuntos de significados e ações relativos à saúde e à doença característicos de diferentes grupos sociais. Contudo, esses estudos tendem a estabelecer uma cisão entre representações e práticas, pois são usualmente marcados pela idéia de uma nítida relação de determinações das representações sobre as práticas, de tal forma que estas últimas são vistas como passíveis de serem deduzidas do sistema construído de representações (Alves \& Rabelo, 1998a).

Conforme têm insistentemente ressaltado muitos teóricos sociais contemporâneos, é necessário que reelaboremos as relações entre pensamento e ação, consciência e corpo, cultura e individualidade (Ritzer, 1990; Alexander et al., 1987; Knorr-Cetina \& Cicourel, 1981; Giddens, 1984; Bourdieu, 1987). Partimos do pressuposto de que o conceito de experiência parece nos indicar pistas significativas em que se entrecruzam essas dimensões. Um postulado básico desse conceito é o de que o fenômeno social não é soma de subjetividades nem tampouco uma realidade objetiva (estrutura simbólica, modo de produção, integração entre sistemas social, cultural e de personalidade ou mesmo sistema de disposições duráveis).

Como observa Merleau-Ponty (1994:487), a classe e a nação - e poderíamos acrescentar o gênero - "não são fatalidades que submetam o indivíduo do exterior; nem tampouco valores que ele ponha do interior. Elas são modos de coexistência que o solicitam". O conceito de experiência expressa uma preocupação de problematizar e compreender como os indivíduos vivem seu mundo, o que nos remete às idéias de consciência e subjetividade, mas também, e especialmente, de intersubjetividade e ação social.

Problematizar a idéia de experiência significa assumir que a maneira como os indivíduos compreendem e se engajam ativamente nas situações em que se encontram ao longo de suas vidas não pode ser deduzida de um sistema coerente e ordenado de idéias, símbolos ou representações. (Rabelo, Alves \& Souza, 1999:11)

As narrativas que as mulheres produzem acerca de suas vidas constituem dimensões importantes da experiência do nervoso, na medida em que põem à vista uma relação percebida entre sujeito e contexto, fundadora dessa experiência. A narrativa é uma instância privilegiada para a compreensão de como os indivíduos ou grupos sociais dão significado às suas histórias, entrevêem os numerosos e variados eventos, encontros, acidentes e ações que caracterizam a esfera do vivido. Como observa Ricoeur (1991), na narrativa, sujeito e ação se constituem mutuamente. O sujeito que narra um evento que lhe ocorreu revela-se por intermédio das ações que empreendeu e em que se envolveu; estas, por sua vez, aparecem como desenvolvimento necessário do próprio personagem. Assim, a análise dos processos narrativos pelos quais as mulheres idosas e nervosas reconstituem suas experiências 'fragilizantes' evidencia o fato de que a relação entre os padrões de comportamentos relacionados com eventos tidos como potencialmente problemáticos para a condição feminina - tais como morte da mãe, casamento, reprodução - e as suas respectivas experiências não é intrínseca, universal. 
Tendo em vista as considerações teórico-metodológicas aqui resumidas, perguntamos: o que caracteriza o discurso (a narrativa) de mulheres idosas, consideradas por elas mesmas e pela comunidade local como 'nervosas', quando relatam acontecimentos vivenciados, tidos como 'fragilizantes' para sua condição feminina? Antes, contudo, apresentaremos breves informações sobre as pesquisas que embasaram essa discussão e a concepção de nervoso existente no Nordeste de Amaralina.

\section{A Pesquisa}

Conforme já observado, a pesquisa que fundamenta a nossa discussão foi desenvolvida no Núcleo de Estudos em Ciências Sociais, Ambiente e Saúde (Ecsas) da Universidade Federal da Bahia, de 1993 a 1997. Essa investigação tanto obteve dados sobre a vida das mulheres residentes em um dos mais populosos bairros de classe trabalhadora de Salvador (Nordeste de Amaralina), ${ }^{4}$ sua inserção na família, as redes sociais de apoio a que recorrem e as experiências problemáticas que elas enfrentam em suas vidas, quanto procurou compreender de modo mais aprofundado a experiência dessas mulheres com problemas relativos ao campo da saúde mental, especificamente tidas como 'nervosas'. A primeira fase da pesquisa constituiu-se na realização de um pequeno survey. Foram escolhidos aleatoriamente 120 domicílios, com o objetivo de aplicar a uma mulher residente em cada um deles um extenso questionário. ${ }^{5}$

O questionário era composto de quatro blocos de questões semi-estruturadas sobre família, redes sociais, tratamento, calendário de eventos da vida da mulher. $\mathrm{O}$ objetivo do calendário foi o de reconstituir a trajetória de vida de mulheres, pontuando 34 acontecimentos usualmente identificados na literatura como marcantes no curso de vida da mulher, contando com questões referentes aos principais momentos, acontecimentos e relações que potencialmente tiveram um efeito 'fragilizante' (ou protetor) sobre elas. ${ }^{6} \mathrm{O}$ calendário, portanto, buscou identificar os tipos de eventos 'fragilizantes' que marcam a trajetória das mulheres.

$\mathrm{Na}$ segunda fase da coleta de dados, foram entrevistadas em profundidade 30 mulheres consideradas como 'nervosas', sendo dez delas idosas (acima de 55 anos). Todas elas foram 'acompanhadas' por um integrante da equipe de pesquisa por um período de aproximadamente um ano e submetidas a sucessivas entrevistas com o objetivo de reconstruir seu 'problema de saúde' e sua história de vida. Especial atenção era dada às atividades cotidianas e às relações mantidas entre a informante e os demais integrantes da família, vizinhos, parentes e terapeutas.

Ao perguntarmos nas entrevistas sobre os momentos mais tristes e difíceis das suas vidas, as nossas informantes apontaram para um conjunto de experiências que consideraram como negativas. Em termos hierárquicos, os momentos mais tristes e difíceis para as 105 mulheres não nervosas (idosas ou não) foram: doença de parentes $(80 \%)$; mortes de parentes ou pessoas próximas $(77,5 \%)$; infidelidade conjugal $(75,6 \%)$; morte do marido $(75 \%)$ e perda de bens $(73,7 \%)$. Para as 15 mulheres nervosas (idosas ou não), encontramos: doença própria $(100 \%)$; doença de parentes $(100 \%)$; adoção 
(100\%); morte de filhos (100\%); infidelidade conjugal (90,9\%). Tanto as cinco mulheres idosas e nervosas identificadas na primeira fase da pesquisa quanto as dez entrevistadas e acompanhadas na segunda fase apontaram como as suas piores experiências os seguintes itens: doença própria (14); doença de parentes (14); morte da mãe (14); mortes de parentes (14); morte de filho (13) e infidelidade conjugal (13).

As doenças e as mortes aparecem como os eventos mais problemáticos tanto para as mulheres nervosas quanto para as não nervosas. Aquelas que passaram por essa experiência consideraram-na como um dos piores momentos da sua vida. Para as nervosas, a experiência mais problemática diz respeito ao seu próprio estado doentio. Para ambos os grupos, a doença de parentes é uma experiência com a qual é difícil lidar, principalmente quando os cuidados com o doente ficam ao seu encargo. Interessante é observar que os episódios de doenças entre os parentes, mencionados pelas nervosas como os que causaram maiores sofrimentos, foram, em ordem decrescente, a doença da mãe, de filhos, irmãos, pai, avós e marido. O marido ocupa o último lugar. As mortes são também problemáticas, principalmente quando se trata da mãe e de fillho. A morte do marido não constitui para essas mulheres um evento de alta gravidade. As mulheres não nervosas parecem sofrer muito mais com a morte do marido do que com a dos filhos. Vejamos alguns fragmentos de entrevistas:

Tem uns dez anos que ele [o marido] morreu. Não foi muito difícil, não. Ele me batia desde moça. Eu tive que dá duro. (68 anos, nervosa)

Morte de marido? Teve sim... Mas não me lembro mais quando foi. (60 anos, nervosa)

Eu, ói, eu pedi a Jesus... Chorando e pedindo a Deus que Deus levasse ou a mim ou a ele. Pedi a Deus também que Deus não deixasse também ele maluco pra eu ver, pra eu passar a ver ele nos tonel de lixo, nem nas calçada. Foi um pedido que eu fiz a Jesus e ele me ouviu. Aí morreu... Descansou ele e descansou a mim também. (58 anos, nervosa)

Para melhor comparar essas diferenças, podemos agrupar os 34 eventos estudados em duas grandes tipologias: 1) de ordem afetivo-relacional, que envolve eventos tais como namoro, primeira união ou casamento e primeira relação sexual; 2) eventos reprodutivos (menarca, gravidez, menopausa, esterilização, primeiro e último parto). As experiências negativas das mulheres nervosas com relação à primeira tipologia (afetivorelacional) são proporcionalmente maiores do que as das demais mulheres. Elas apontam como problemático o primeiro namoro e a primeira relação sexual. Quanto à primeira união ou casamento, há uma tendência generalizada a considerá-la boa na primeira etapa, mas problemática com o passar do tempo. As mulheres se queixam da pouca colaboração econômica dos seus companheiros, do uso de bebida, dos maus-tratos e da violência doméstica. Vejamos alguns exemplos ilustrativos para o conjunto dessas observações:

Foi aos 13 anos. Não gostei porque eu não gostava dele. Traí muito esse homem. Eu não tinha muito juízo. (60 anos, relato sobre a primeira relação sexual)

Eu não queria, gritei, chorei, fui forçada. Naquela época eu tinha 12 anos. (55 anos, nervosa) 
Foi aos 21 anos. Eu desmaiei. Nem sabia o que era isso. Era inocência, mesmo. (58 anos, nervosa)

Foi bom no começo porque ele não era homem de rua. O que ele tinha era pra mim. (65 anos, nervosa)

No começo foi bom, mas depois passei o diabo. Na época de casada sofri muito, ele chegava todo dia 'bebo' em casa, batia em mim, quebrava tudo da casa. Era um sofrimento. (71 anos)

Eu não me apaixonei assim. Eu gostava dele, mas não tinha essa paixão, você entendeu? Depois a gente convivendo e tal, eu passei mesmo a gostar, mas não para dizer que eu era apaixonada... Aí foi quando nós casou. Eu vivia muito bem com ele, vivia bem mesmo, tinha do bom e do melhor, enquanto ele pôde (...) Depois, pronto. Aí... Ave, Maria... Ele começou a beber... (63 anos, nervosa)

Os eventos reprodutivos têm em geral uma avaliação positiva entre as mulheres. Contudo, algumas diferenças são significativas. Para os casos das nervosas, 44,4\% tiveram problemas com os partos e 14 idosas (cinco identificadas pelo questionário e dez entrevistadas) com a menopausa. Os principais problemas citados com relação ao parto referem-se a questões de ordem biológica (complicação, desconforto e morte do feto) e emocionais, como o fato de encontrar obstáculos na aceitação da sua família de origem e o pai não ter assumido o filho. A menopausa é tida como um período de agonia, calores e maior nervosismo. Gravidez e esterilização não apresentam maiores problemas para a mostra estudada. $\mathrm{O}$ aborto parece ser menos problemático para as nervosas do que para as outras mulheres. Quanto ao uso de anticoncepcionais, a relação é inversa.

\section{O Nervoso}

O nervoso tem sido objeto de vários estudos no campo da antropologia. A essa questão têm sido dadas várias respostas: o nervoso é uma categoria polissêmica (Davis, 1989; Guarnaccia, 1989; Low, 1994), usada e manipulada em situações de interação (Rebhun, 1993), característica de um determinado modo de pensar a pessoa (Duarte, 1986). Na perspectiva aqui adotada, consideramos o nervoso como um comportamento diretamente ligado a uma dinâmica interativa na qual conduta e modo de ser do indivíduo são considerados como estranhos ou alheios a um padrão normal de comportamento. Assim, esse conceito refere-se a construções culturais herdadas e utilizadas em determinadas situações de aflição. Em termos mais específicos: diz respeito a um conjunto complexo de signos, significados e práticas, identificados pelos indivíduos (no caso, moradores do Nordeste de Amaralina), ao qual se relacionam diversas situações e contextos causais. Tal concepção fundamenta-se nas pesquisas realizadas pelos membros do Ecsas no Nordeste de Amaralina. ${ }^{7}$

Nesse bairro, o nervoso constitui uma aflição bastante conhecida. Nos relatos de seus moradores sobre casos conhecidos de pessoas nervosas, ressalta-se, em primeiro lugar, o fato de que o nervoso é uma reação inadequada ou desproporcional em 
relação a um dado contexto. O nervoso é expresso como algo incontrolável. Está associado à falta de controle, isto é, à incapacidade da pessoa de exercer ação direta sobre o ambiente. Vejamos alguns exemplos:

Eu acho [nervoso] assim... você está conversando com a pessoa na calma. Aí uma pessoa fala uma coisa com você, bem, uma coisa besta, e a pessoa já leva aquilo para uma coisa mais alta. Já vai lhe agredindo. Uma coisa, uma besteira mesmo...

Meu marido mesmo era supernervoso, nervoso, nervoso mesmo pra valer. Ele era capaz de estrangular se estivesse nervoso.

E aí ela deu pra ficar nervosa, assim, e a gente falava qualquer coisa, ela respondia com aquele... Como é que se diz?... Com aquela força, agitada.

Ela vivia muito nervosa, falava muito. Ninguém chegasse na casa dela que ela mandava vir embora. Não queria ninguém lá, tava irritada, achava que tavam bulindo com ela, dizendo as coisas a ela.

Quando ela tá atacada, ela começa a xingar o povo dela mesmo.

Fica trancada dentro de casa, chora, chora. Quando ela tá com vontade, bota a casa um espelho. Quando não tá, fica tudo de perna para cima. Quando ela tá com vontade, pega as roupas, arruma, lava, passa, bota dentro do armário. Quando não tá, larga tudo lá, bagunçado.

Trata-se, portanto, de um 'problema mental', mas não necessariamente de 'loucura', isto é, a perda radical e definitiva do ‘juízo'. É importante observar, contudo, que a distinção entre 'loucura' e 'nervoso' nem sempre é clara. De maneira mais geral, o 'nervoso' é descrito como um estado menos grave e comprometedor de enfraquecimento da capacidade pessoal de julgamento ou discernimento nas interações sociais, campo de atuação do ‘juízo’, cujo comprometimento reflete-se claramente no desempenho social do indivíduo. Nesse aspecto, o enfraquecimento dos nervos pode ser temporário - diz-se então que a pessoa 'está nervosa' - ou trata-se de uma tendência mais duradoura; neste caso, diz-se que a pessoa 'é nervosa'.

O nervoso está relacionado a alguns signos que podemos agrupar em três conjuntos básicos de comportamento: agressividade e violência, agitação e impaciência e, por último, isolamento. A pessoa nervosa é geralmente descrita em termos de agressividade exagerada e/ou fora de contexto. O nervoso, assim, é um estado em que o indivíduo facilmente apela para a agressão (física ou verbal), se altera por nada, criando "cenas" tanto no domínio da casa quanto no espaço público da rua. A pessoa é retratada como "invocada" e, portanto, como alguém que não oferece um terreno favorável para a interação. Essa descrição geralmente é mais comum para o homem, embora muitas mulheres assim também possam ser definidas. A presença da violência ou da agressão é particularmente problemática quando dirigida a pessoas que, por definição, devem ser objeto de atitude de respeito ou mesmo submissão, como os membros da família, principalmente a mãe.

Nervoso também está relacionado a pessoas agoniadas, a quem falta tranquiilidade, que se mostram sempre insatisfeitas ou excessivamente preocupadas diante dos problemas do cotidiano. São descritas como aquelas "que andam de um lado para o 
outro", "tremem o corpo inteiro" e por qualquer razão riem demais ou choram em excesso. São pessoas "avexadas", "agoniadas", “insistentes”. Mas 'nervoso' designa também aquele indivíduo que procura isolamento, tranca-se em sua casa e evita contato com outros. $\mathrm{O}$ isolamento está associado, por um lado, à indisposição e à falta de ânimo, que remetem às idéias de força e fraqueza; e por outro, à condição de estar "aperreado" ou "amuado", o que pode adquirir uma conotação moral negativa, uma vez que ameaça um fluxo de reciprocidade. A pessoa que "se joga no desprezo" (descuida-se de si mesma) tem seu comportamento visto como uma dinâmica de isolamento, sendo muitas vezes alvo de reação de condenação moral explícita. A pessoa nervosa, por outro lado, é sujeita a tristeza e ansiedade.

As mulheres nervosas são descritas como "angustiadas", "amuadas", "distantes do mundo". Essas características ficam mais em evidência nos discursos das próprias nervosas. Ao falarem de si mesmas, do seu nervoso, as mulheres tendem a articular as suas trajetórias de vida e seus problemas com sentimentos de angústia e tristeza.

Ao falar dos signos do nervoso, é importante assinalar o significado atribuído à normalidade ou melhora. De maneira geral, a normalidade é identificada com a disposição para o trabalho, isto é, relaciona-se à força, a um estado de plena posse das capacidades físicas e mentais. $\mathrm{O}$ trabalho, na maioria das narrativas, é uma categoria importante na construção e na afirmação da identidade. Normalidade é também identificada pelo cuidado com a aparência. Demonstrar interesse pela higiene e pela apresentação pessoal (especialmente em contextos públicos) é ato indicador de que o indivíduo, se tem o "juízo fraco", não cortou de todo os laços sociais que lhe conferem o status de pessoa. A normalidade está também associada à manutenção de um certo equilíbrio ou bom senso na relação com os outros. A pessoa nervosa se opõe claramente a essa concepção com seus descompassos e exageros, por tomar qualquer ação ou palavra como insulto ou agressão a si.

Em síntese, o nervoso, no Nordeste de Amaralina, é descrito como uma perda temporária do controle sobre as próprias atitudes ou reações (ou tendência a isto). Mas é importante observar que, nas narrativas, o "enfraquecimento do juízo" desenrola-se no transcurso de relações sociais que terminam por vitimar o indivíduo. O tempo do nervoso é um tempo social, em que transcorre uma pluralidade de acontecimentos, incidentes e encontros nos quais o indivíduo, sem necessariamente ter conhecimento, pode estar implicado. Assim, na velhice, é de se esperar que uma pessoa nervosa acumule um conjunto de experiências 'negativas'.

Os relatos sobre nervoso no Nordeste de Amaralina são expressos em termos de conjunções específicas de situações ou relações 'fragilizantes', envolvendo outras pessoas, o ambiente (social ou natural) e o 'mundo dos espíritos'. Nesse aspecto, o nervoso raramente se apresenta como resultado de uma cadeia única de eventos e causas.

Uma irmã, descrevendo o nervosismo do irmão, nos relata:

Para mim, ele tava cansado, fraco, esgotado. Do trabalho, né? E... e porque aquela criação que eu dava a eles. Era uma alimentação muito frágil, muito pouca, sabe? Então eu achava assim. (...) Ele é magrinho e fraco. Então o pai morreu e ele ficou naquela luta, né? Aquela luta, aquela preocupação, aquela coisa que apossava nele. Ainda hoje ele conta. Quando ele chegava do jornal, com aqueles trocados 
que davam a ele, ele comprava pão, comprava o guaraná e tomava com o irmão caçula aqui. Aí o barraco caiu. O buraco caiu, foi no chão, nós ficamos desabrigado.

(...) Enquanto tava o pai e a mãe, tudo junto tratando dele, não tinha problema, né? (...) Mas o pai morreu, ele preocupado com aquela morte, apossado com aquela idéia. Assim, ficar sem o pai e uma coisa e outra. De forma que aquilo virou uma doença, de repente.

Assim, o nervoso é resultado de um processo de fragilização não apenas de um indivíduo, mas principalmente de um grupo social mais amplo. É parte de um processo de fragilização da família, o que pode implicar tanto um empobrecimento e desorganização interna quanto um certo senso de perda da unidade moral. Em várias narrativas, a descrição do contexto em que se desenha o nervoso expressa situações de fraqueza na família, como violência excessiva, desvio do papel de marido/pai, desvio do papel hierarquicamente subordinado de filho, desvio do papel da mãe na educação dos filhos. É importante observar que a força da família, no Nordeste de Amaralina, depende da manutenção de um contínuo fluxo de trocas entre os atores que estão diferentemente situados no contexto.

Não podemos esquecer também que nas histórias contadas no Nordeste de Amaralina sobre nervoso é comum que seus locutores atribuam a causa da aflição a intervenções espirituais, além do contexto familiar de referência. Em muitos relatos, estabelecem-se elos entre certos comportamentos e a intervenção de forças não humanas.

\section{A Experiência do Nervoso em Mulheres Idosas}

No Nordeste de Amaralina, como já observamos, o nervoso é expresso como algo incontrolável, revelando reações exageradas ou desproporcionais a um dado contexto. Assim, seu significado só pode ser compreendido quando se recupera a relação com o contexto que as suscita. Mas, antes de falarmos sobre esse aspecto relacional, vejamos como as mulheres idosas relatam seu nervoso no domínio propriamente físico ou corporal.

Em todas as narrativas, as mulheres idosas descreveram o seu nervoso com imagens de abafamento, calor na cabeça, agonia, dor nas pernas, na cabeça, irritabilidade. Mas também descreveram imagens de tristeza, distanciamento do mundo, isolamento. É interessante notar que nos relatos genéricos sobre o nervoso em mulheres idosas (isto é, naqueles relatos produzidos por informantes que falam sobre casos conhecidos) dominam os signos relacionados a sensações corporais (dores, fraquezas, tremores etc.). A tristeza só é mencionada nos relatos de pessoas, principalmente mulheres idosas, que se identificam como nervosas. Assim é que D. Maria (nervosa, 63 anos) descreve o seu nervoso como algo que a deixa impotente, deitada no sofá com os olhos cheios de lágrimas. Ela diz que, quando

atacada pelo nervo, (...) fica assim, em cima da cama, olho, muda de um lado, só olhando a rua, os menino briga, eu olho. Nego xinga meus netos e eu olho, sem poder falar, não posso fazer nada. A cabeça fica assim pensando. Um dia eu levanto. Um negócio assim, diz mesmo: ‘Cê vai morrer'... 
O mesmo acontece com as crises de D. Maria José (nervosa, aproximadamente 58 anos), quando ela sente como se os nervos fossem "desmoronar":

Me sentia assim, ó... aquela dor de cabeça, não doía assim a cabeça toda não, daqui pra aqui, parecendo um martelo a dor de cabeça. Fazia tim, tim, me chegava a azuá mesmo. Eu não podia ver ninguém, falar, eu não podia ouvir zuada. (...) Aí, pronto, eu começava a chorar. Aí me dava aquele ódio, aí eu chorava, chorava, chorava e ficava triste.

Quando as crises de nervos que acometem D. Maridalva (nervosa, 61 anos) configuram-se em excesso de riso e tremores no corpo ("Começa assim, sabe? Aquele riso alto, alto, alto. Aí vai ‘esmurecendo', me lasca toda, é uma coisa de doido.”), ela nos diz que se bate muito, se "estraçalha" e se "espedaça toda".

A vivência cotidiana no bairro aparece em muitos dos depoimentos das mulheres idosas e nervosas como elemento agravador da sua aflição. Devemos observar que o estilo de vida no Nordeste de Amaralina, assim como em muitos outros bairros de classe trabalhadora, é marcado pela importância dada às relações sociais travadas no seu interior. Há uma ampla rede de relações sociais estabelecidas com vizinhos e parentes que vivem nas redondezas. A rua é amplamente ocupada e compartilhada, constituindo-se em espaço de sociabilidade, além de local de passagem. É na rua que as pessoas se encontram, conversam, contam suas histórias, prestam pequenos favores.

Mas a rua é também um espaço de perigo e fofoca. Com as pessoas vivendo tão próximas umas das outras, num mundo em que as relações se tornam quase forçosamente íntimas, os dramas particulares convertem-se quase sempre em dramas públicos. As pessoas continuamente observam e são observadas. Assim, é de se esperar que a cooperação e a solidariedade constituam apenas uma das facetas da convivência entre as pessoas. Há uma boa dose de tensão e ambivalência no cotidiano do bairro. A violência, a circulação de informações sobre a vida alheia, a fofoca, os mexericos, o barulho constante na rua que se prolonga até altas horas são elementos que compõem o dia-a-dia do Nordeste de Amaralina. As manifestações de agressividade marcam também as relações sociais que ocorrem dentro das quatro paredes do lar: os homens 'provam a sua virilidade', os pais fazem uso de força na educação dos filhos, os jovens demonstram pouco respeito aos mais velhos.

Assim, alguns relatos parecem apontar para o fato de que, em um contexto social como o do Nordeste de Amaralina, a pessoa nervosa torna-se mais vulnerável ao olhar dos outros, o que pode constituir fonte de tensão nas relações de vizinhança. D. Tereza (nervosa, aproximadamente 59 anos) associa o seu problema à vida cotidiana do bairro.

E eu tô doida pra terminar minha casa pr'eu sair daqui. Aí eu vou alugar... vou arranjar um canto pr'eu ficar tranqüila, num lugar calmo, porque aqui ... Começa a bater bola... Isso aí é o dia todo. E aí quando chega de noite, o bar aí na porta, aí vai até uma hora, duas horas da manhã, cê entendeu? (...) E eu não tô mais pra ouvir zuada. Tem hora que dá um nervoso... aqui no quarto. (...) Agora eu durmo assim, assustada (...) porque depois dessa invasão a gente não tem paz (...) Hoje, pra dormir, eu tenho que tomar remédio (...) porque esses meninos pertuba... 
Nos seus relatos, as mulheres revelam recorrer constantemente a médicos, exames, remédios, cultos religiosos. As redes de parentesco e vizinhança têm também um papel fundamental na escolha e na apreciação do tratamento e, portanto, na definição do problema e na avaliação que o próprio doente faz de si. O tratamento de uma pessoa nervosa depende em grande medida dessa rede. Mas é digno de nota que a concordância sobre formas de tratamento a serem seguidas não é regra. Há muitas divergências sobre a escolha e a avaliação da terapia mais apropriada para um determinado caso.

O tratamento pelo uso de medicamentos psiquiátricos é muitas vezes abusivo. As mulheres idosas e nervosas atribuem alto valor ao consumo de remédios, combinando-os aleatoriamente. O remédio significa tanto possibilidade de alívio do sofrimento quanto a sua legitimação como doença. As consultas aos médicos são feitas quase que exclusivamente para questões ligadas à medicação. Paralelamente ao uso de medicamentos psiquiátricos e consultas médicas, as mulheres também buscam terapia em diferentes agências religiosas.

Quando na história de vida das mulheres que se referem a si mesmas como nervosas buscamos o sentido da experiência de fragilização, encontramos certos temas básicos. $\mathrm{O}$ primeiro deles está conectado com a sensação de perda ou de fraqueza. Como já observamos, nervoso é enfraquecimento dos 'nervos', o que significa dizer impotência ou perda da autodeterminação. Na velhice, esse enfraquecimento torna-se ainda mais aguçado.

Para as mulheres idosas e nervosas, a perda da autodeterminação está conectada em primeiro lugar com o enfraquecimento ou "esmurecimento" do corpo. Assim, a história do nervoso é também a história da perda gradativa da beleza e vitalidade. No corpo, vêem espelhada uma trajetória de declínio. Na velhice, as transformações físicas que ocorrem no corpo, a perda da força e da vitalidade física são vistas como marcas de sofrimentos deixadas por muitos eventos críticos. Nos seus relatos, as mulheres idosas e nervosas contam como eram fortes, gordas e atraentes, mas, devido aos numerosos sofrimentos, acabam na situação atual: magras, cansadas, com falta de disposição, incapazes de gerir a vida. D. Maria (nervosa, 63 anos) expressa o declínio do seu corpo como uma sensação de estar "diminuindo" ou "descendo". Ao voltar-se para o passado, descreve-se como uma pessoa gorda, bem-feita, dentes e cabelos bonitos, desejada e objeto de ciúme. Agora, após uma vida de padecimento, considera-se doente, ossuda, evitada pelo parceiro de anos.

O nervoso se desenha nos depoimentos das mulheres não apenas como enfraquecimento do corpo, mas também como impossibilidade de sustentar ou manter uma certa identidade pessoal e, portanto, também uma certa rede de relacionamentos com os outros que sustente essa identidade. Na velhice, o nervoso aparece como impotência ou fracasso de um determinado projeto de vida. De maneira geral, está associado a um contexto de quebra de vínculos no interior da família e principalmente com os companheiros; há um sentido de fragilização que aponta para um sentimento de estar desconectado ou privado de uma teia bem definida de relações de reciprocidade da qual emerge a identidade de mulher.

Nas suas narrativas, as mulheres nervosas expressam a dificuldade de realizar um projeto de vida de acordo com um modelo de mulher ideal - mãe, esposa, responsável pela casa etc. Essas histórias revelam a vivência de traições, de violência e de 
abandono por parte de seus companheiros, e até mesmo por parte da família extensa, uma situação que as leva a ter que arcar sozinhas com a responsabilidade de manter a casa e criar os filhos. Diante dessas dificuldades, as mulheres tendem a construir uma identidade alternativa de pessoas fortes, corajosas e orgulhosas (que criam os filhos sozinhas, recusam-se a pedir ou receber ajuda daqueles que não demonstram piedade ou simpatia pelo seu estado, não têm medo de marginais etc.). Sem que se compreenda o contexto geral que faz de muitas mulheres de classe trabalhadora urbana chefes e provedoras e no qual elaboram-se imagens positivas da mulher sofrida mas orgulhosa e forte, dificilmente pode-se compreender o sentido da experiência dessas mulheres.

No Nordeste de Amaralina, as reações às aflições dessas mulheres variam não apenas de acordo com o grau de proximidade dos sujeitos, mas também de acordo com o sentido geral atribuído ao nervoso. Usualmente, elas despertam pena e recebem algum conforto por parte dos familiares e vizinhos mais próximos. Afinal, essas mulheres representam a figura da mulher sofrida e que se sacrificou para criar os filhos por conta própria e que agora se abate com a vivência da velhice.

\section{CONCLUSÃO}

Quando caracterizamos rapidamente as duas grandes vertentes interpretativas sobre a relação entre mulher e saúde mental - a 'biologicista' e a 'sociologista' -, chamamos a atenção para o fato de que ambas pressupõem uma 'natureza intrínseca e objetiva da condição feminina'. Elas terminam por não levar em devida consideração a dimensão intersubjetiva da vida em uma dada configuração sociocultural. Assim, terminam "por falar do humano - o objeto por excelência das ciências sociais - como uma realidade sem vida, entidade quase morta, subsumido às forças onipotentes de uma estrutura" (Alves \& Rabelo, 1998b:23-24).

Uma abordagem centrada na experiência, por sua vez, permite-nos reconhecer dimensões importantes do nervoso que escapam tanto aos estudos biomédicos quanto aos trabalhos desenvolvidos nas ciências sociais pela ótica da 'teoria das representações'. Os relatos que as mulheres idosas e nervosas elaboram sobre si próprias não apenas refletem uma percepção do mundo, mas conduzem a modos específicos de ser no mundo. Conforme procuramos mostrar, as narrativas dessas mulheres sobre a sua aflição são discursos que expressam e configuram uma identidade pessoal. Nos seus relatos, sujeito e ação se constituem mutuamente: a pessoa nervosa revela-se pelas ações que empreende ou em que se envolve e estas aparecem como desenvolvimento necessário da própria identidade do ator/personagem. Ao narrar suas histórias, nossas informantes tanto apontam para experiências de eventos problemáticos - experiência vivida de fragilização - quanto contribuem para constituir essas experiências. Nervoso é um modo de ser no mundo.

Não podemos esquecer que a narrativa é o processo pelo qual o indivíduo confere uma significação à sua biografia. Conforme frisa Ricoeur (1991), a narrativa oferece ao indivíduo uma instância privilegiada para a compreensão de si próprio, uma vez 
que totaliza o que é vivido de modo fragmentário, pontual. Para que a vida de uma determinada pessoa possa ser interpretada como uma totalidade singular, é preciso que o indivíduo seja capaz de colocá-la num certo curso.

As narrativas de nervoso, portanto, referem-se a um modo próprio de ser no mundo. Trata-se, assim, de uma experiência que implica emoções, uma forma pela qual o indivíduo apreende sua situação particular em um dado contexto. A emoção é um processo que envolve um self que se situa e se orienta de maneira particular em face de determinada situação. As narrativas de nervoso representam uma tentativa de interpretar a experiência emotiva, revelando tanto os padrões culturais gerais que orientam a interpretação quanto a tentativa do indivíduo de objetivar sua experiência com base nesses padrões. ${ }^{8}$ A partir dessa premissa é que podemos compreender melhor como as mulheres idosas e nervosas, residentes no Nordeste de Amaralina, entendem e vivenciam suas aflições.

Ao refletirmos sobre os relatos que as mulheres produzem sobre suas experiências do nervoso, a primeira observação a ser feita é que suas narrativas estão cheias de referências a acontecimentos descritos como 'fragilizantes'. Vários dos 34 eventos listados pela pesquisa e vivenciados por elas foram considerados como problemáticos. Trata-se de acontecimentos ocorridos em diferentes momentos no curso das suas vidas. O nervoso aparece justamente em situações de dificuldade e crise. Mas ao narrar suas aflições, essas mulheres justapõem e combinam entre si essas experiências, de tal forma que parecem expressar uma organização seqüencial em que cada evento pressupõe outro. As dificuldades e as crises passadas não são tomadas isoladamente. Pelo contrário, remetem a uma cadeia sucessiva de eventos, formando uma unidade articulada. Em síntese, são discursos que buscam conferir coerência, uma unidade articulada de sentido, a atos fragmentados, passados.

No Nordeste de Amaralina, a narrativa do nervoso é quase sempre um discurso sobre si mesmo. As narrativas de experiências do nervoso estão mescladas com a totalidade da vida da pessoa. As mulheres nervosas são especialmente suscetíveis de falar de si mesmas como pessoas nervosas e de explicar o seu significado por meio de considerações mais pessoais sobre suas vidas e seus problemas. São relatos que explicitam vidas de consumição, um desenrolar sofrido de eventos, de constantes referências a um contexto de pobreza e violência. Esses acontecimentos terminaram por torná-las vulneráveis; fragilizaram-nas ao longo do tempo, deixando-as cada vez mais nervosas.

Os relatos de nervoso são discursos de experiências de fragilização e desgaste no curso da vida. Mas, ao mesmo tempo, em contraponto a esse discurso de fragilização, as histórias narradas são também relatos de pessoas fortes, de mulheres sofridas, mas orgulhosas. Assim, terminam por manter uma imagem positiva do ser humano capaz de arcar sozinho com as responsabilidades impostas pelo mundo social em que vive.

Quero agradecer a colaboração de Miriam Rabelo pela sua criteriosa leitura e pelos valiosos comentários. A Iara Maria Souza e Maria Gabriela Hita, por sua participação nas pesquisas que geraram este trabalho. Miriam, Iara e Gabriela coordenaram setores 
importantes da investigação. Tenho também dívida de gratidão para com os bolsistas Paula Schaeppi, Litza Cunha, Suely Messeder, Lícia Barbosa, Suely Motta, Juliana Rocha, Salete Nery e Osvaldo Bastos, que participaram do trabalho de campo. E um agradecimento particular a Cecília Sepúlveda, bolsista e estudante do curso de Ciências Sociais, pela ajuda na tabulação e na análise dos dados quantitativos. Agradeço também os comentários instigantes de Carlos Coimbra Jr.

\section{NotAs}

1 Para uma criteriosa e bastante ilustrativa análise sobre a construção gerontológica da velhice, ver Debert (1997, 1999).

2 O conceito de experiência e seu uso na antropologia da saúde é por nós discutido em seus diversos ângulos em Rabelo, Alves \& Souza (1999). Observe-se que parte da discussão aqui apresentada já foi desenvolvida no referido livro.

3 Pesquisa financiada pelo CNPq e pela Fundação Carlos Chagas. A professora Maria Gabriela Hita, integrante do Ecsas, foi sua co-coordenadora.

4 O Nordeste de Amaralina ocupa uma área de 250 hectares, aglutinando aproximadamente 90 mil habitantes que vivem em pouco mais de 14 mil casas residenciais. Quarenta por cento de seus residentes têm idade inferior a 15 anos e $60 \%$ dos moradores são migrantes rurais. A pobreza é um dado característico do bairro, e apenas $11 \%$ da população completaram o primeiro grau escolar, atual ensino básico.

5 A metade das entrevistadas (51,7\%) tinha menos de 35 anos de idade; $35,8 \%$, entre 35 e 59 anos; $12,5 \%$ (15) tinham 60 anos ou mais (22 mulheres tinham acima de 55 anos). Das 120 mulheres entrevistadas, 15 eram consideradas no bairro (e assim se auto-intitulavam) como nervosas, sendo que cinco delas tinham mais de 55 anos. Quanto ao estado civil, 17,8\% eram solteiras, 61,8\% unidas ou casadas e $20,4 \%$ separadas ou viúvas. Das 120 mulheres entrevistadas, $11,9 \%$ declararam que nunca tiveram filhos; $15,3 \%$, apenas um; 55,9\%, entre dois e seis; e 16,9\%, sete filhos ou mais. No total das respondentes, $15,3 \%$ declararam nunca ter estudado; 33,9\% não completaram o antigo primário; 30,5\% tinham primário completo; e 20,3\% terminaram o primeiro grau (atual ensino médio).

6 Os 34 eventos foram: 1) nascimento; 2) adoção; 3) entrada na escola; 4) saída da escola; 5) morte do pai; 6) morte da mãe; 7) outras mortes marcantes; 8) primeiro namoro; 9) primeira relação sexual; 10) primeira união ou casamento; 11) outras uniões; 12) primeira gravidez; 13) primeiro parto; 14) último parto; 15) aborto; 16) esterilização; 17) uso de anticoncepcionais; 18) primeira separação; 19) participação no bairro; 20) começo do trabalho; 21) períodos longos sem trabalhar; 22) desemprego do cônjuge; 23) perda de bens; 24) morte do marido; 25) morte de filho(a); 26) casamento do(a) primeiro(a) filho(a); 27) migração; 28) doença própria; 29) doença de parente; 30) incesto ou intento; 31) prisões; 32) primeira menstruação; 33) menopausa; 34) infidelidade conjugal. 
7 Trata-se dos seguintes trabalhos: Signs, Meanings and Practices Related to Mental Health (1991-1994), financiado pelo IDRC-Canadá e sob a coordenação geral de Naomar Almeida-Filho; Illness Management Strategies and Mental Health Systems in Bahia, Brazil (1994-1997), também financiado pelo IDRC e sob a coordenação de Carlos Alberto Soares, Paulo César Alves e Míriam Rabelo; A Lógica do Itinerário Terapêutico (1991-1994), financiado pela Opas e pelo CNPq, sob a minha coordenação.

8 Essas considerações são importantes porque na literatura antropológica há uma tendência a reduzir as emoções a um nível tanto biológico quanto cultural. A emoção, antes de ser um conjunto de estímulos que a cultura permite comunicar e regular em contextos sociais (Hoschild, 1979; Spiro, 1984) ou um elemento de um sistema ou código cultural (Strathern, 1975; Lutz, 1988), supõe um sujeito situado no mundo e dirigido a ele. Como observa Geertz (1978), é o resultado de uma percepção, por parte do indivíduo, de que existem incongruências entre o papel ou ideal de pessoa vigente e sua representação cotidiana ou trajetória nesse papel.

\section{ReferênCIas Bibliográficas}

ALEXANDER, J. et al. The Micro-Macro Link. Berkeley: University of California Press, 1987.

ALMEIDA-FILHO, N. The psychosocial costs of development: labour, migration and stress in Bahia, Brazil. Latin America Research Review, 17:91-118, 1982.

ALVES, P. C. \& RABELO, M. C. Repensando os estudos sobre representações e práticas em saúde/doença. In: ALVES, P. C. \& RABELO, M. C. (Orgs.) Antropologia da Saúde: traçando identidade e explorando fronteiras. Rio de Janeiro: Relume-Dumará, Fiocruz, 1998a.

ALVES, P. C. \& RABELO, M. C. O status atual das ciências sociais em saúde no Brasil: tendências. In: ALVES, P. C. \& RABELO, M. C. (Orgs.) Antropologia da Saúde: traçando identidade e explorando fronteiras. Rio de Janeiro: Relume-Dumará, Fiocruz, 1998b.

AYRES, J. R. C. Sobre o Risco: para compreender a epidemiologia. São Paulo: Hucitec, 1997.

BARROSO, C. Sozinhas ou Mal Acompanhadas: a situação das mulheres chefes de família. Campos do Jordão: ENCONTRO NACIONAL DE POPULAÇÃO [ABEP], I, 1978.

BOLLES, A. L. Economic crises and female-headed households in Oban Jamaica. In: NASH \& SEFIED (Eds.) Women and Change in Latin America. Massachusetts: Bergin \& Garvey, 1985.

BOURDIEU, P. Outline of a Theory of Practice. Cambridge: Cambridge University Press, 1987.

BROWN, G. W. \& HARRIS, T. Social Origins of Depression. Londres: Tavistock, 1978.

CHESLER, P. Women and Madness. Nova Iorque: Avon, 1972.

CHOITON, A. et al. The patterns of medical drug use. Canadian Medical Association Journal, 114:33-47, 1976.

COUTINHO, D. M. Prevalência de Doenças Mentais em uma Comunidade Marginal: um estudo do Maciel, 1974. Dissertação de Mestrado, Salvador: Universidade Federal da Bahia. 
CSORDAS, T. Embodiment as a paradigm for medical anthropology. Ethos, 18:5-47, 1990.

DAVIS, D. The variable character of nerves in a newfoudland fishing village. American Anthropologist, 11:63-78, 1989.

DEBERT, G. G. Reinventando o Envelhecimento: socialização e processos de reprivatização da velhice. Campinas: IFCH/Unicamp, 1997.

DEBERT, G. G. A construção e a reconstrução da velhice: família, classe social e etnicidade. In: NÉRI, A. L. \& DEBERT, G. G. (Orgs.) Velhice e Sociedade. Campinas: Papirus, 1999.

DOHRENWEND, B. \& DOHRENWEND, B. S. Sex differences in mental illness: a reply to Gove and Tudor. American Journal of Sociology, 82:1.336-1.341, 1977.

DUARTE, L. F. D. Da Vida Nervosa nas Classes Trabalhadoras Urbanas. Rio de Janeiro: Zahar, 1986.

EHRENREICH, B. \& ENGLISH, D. For her Own Good: 150 years of the experts' advice to women. Nova Iorque: Anchor-Doubleday, 1978.

ERIKSON, E.; ERIKSON, J. M. \& KIVNICK, H. Vital Involvement in Old Age: the experience of old age in our time. Londres: Norton, 1986.

GEERTZ, C. Pessoa, tempo e conduta em Bali. In: GEERTZ, C. A Interpretação das Culturas. Rio de Janeiro: Zahar, 1978.

GIDDENS, A. The Constitution of Society. Cambridge: Polity Press, 1984.

GOFFMAN, E. Manicômios, Prisões e Conventos. São Paulo: Perspectiva, 1974.

GOLDANI, A. M. Retrato de Família: o caso do Brasil. Caxambu, 1994: trabalho apresentado em reunião da Anpocs (GT: Família e pobreza no Brasil metropolitano: um balanço dos anos 80).

GOVE, W. Gender differences in mental and physical illness: the effects of fixed roles and nurturant roles. Social Science and Medicine, 19(2):77-91, 1984.

GUARNACCIA, P. The multiple meanings of attacks de nerves in the Latin community. Medical Anthropology, 11:47-62, 1989.

HOSCHILD, A. Emotion work, feeling rules, and social structure. American Journal of Sociology, 85:551-575, 1979.

JELIN, E. Las familias en América Latina. In: SALINAS, C. \& LEÓN, M. (Eds.) Famílias Siglo XXI. Santiago: Isis Internacional, 1994.

KLERMAN, G. Increasing rates of depression. Journal of the American Medical Association, 261:2.229-2.235, 1989.

KNORR-CETINA, K. \& CICOUREL, A. V. Advances in Social Theory and Methodology: toward an integration of micro and macro-sociologies. Boston: Routledge \& Kegan Paul, 1981.

LOCK, M. The politics of midlife and menopause. In: LINDENBAUM, S. \& LOCK, M. (Eds.) The Anthropology of Medicine and Everyday Life. Berkeley: University of California Press, 1993.

LOW, S. M. Embodied metaphors: nerves as lived experience. In: CSORDAS, T. (Ed.) Embodiment and Experience. Cambridge: Cambridge University Press, 1994. 
LUTZ, C. Unnatural Emotions. Chicago: University of Chicago Press, 1988.

MEMMINKI, E. General practitioners' indications for psychotropic drug therapy. Scandinavian Journal of Social Medicine, 2:1-14, 1974.

MARI, J. J. Psychiatric morbidity in three primary care clinics in the city of São Paulo: issues on the mental health of the urban poor. Social Psychiatry, 22:129-138, 1987.

MERLEAU-PONTY, M. Fenomenologia da Percepção. São Paulo: Martins Fontes, 1994.

MILES, A. Women and Mental Illness. Brighton: Harvester Wheatsheaf, 1988.

MURPHY, J. M. Trends in depression and anxiety: men and women. Acta Psychiatrica Scandinavia, 73:113-127, 1986.

NEUPERT, R. Os Arranjos Domiciliares das Famílias Matrifocais. São Paulo: ENCONTRO NACIONAL DE POPULAÇÃO [ABEP], IV, 1988.

OAKLEY, A. The Sociology of Housework. Oxford: Martin Robertson, 1974.

OLIVEIRA, M. C. Família e Modo de Vida nas Classes Trabalhadoras em São Paulo. São Paulo: ENCONTRO NACIONAL DE POPULAÇÃO [ABEP], V, 1992.

RABELO, M. C.; ALVES, P. C. \& SOUZA, I. M. (Orgs.) Experiência de Doença e Narrativa. Rio de Janeiro: Fiocruz, 1999. (Antropologia \& Saúde)

REBHUN, L. A. Nerves and emotional play in Northeast Brazil. Medical Anthropology Quarterly, 7(2):131-151, 1993.

REICHENHEIM, M \& HAPHAM, T. Maternal mental health in a squatter settlement in Rio de Janeiro. British Journal of Psychiatry, 159:683-690, 1991.

RICOEUR, P. O Si Mesmo como um Outro. Campinas: Papirus, 1991.

RIPA, Y. Women and Madness: the incarceration of women in nineteenth-century France. Cambridge: Polity Press, 1990.

RITZER, G. Micro-macro linkage in sociological theory: applying a metatheoretical tool. In: RITZER, G. (Ed.) Frontiers of Social Theory: the new syntheses. Nova Iorque: Columbia University Press, 1990.

ROGERS, A.; PILGRIM, D. \& LACEY, R. Experiencing Psychiatry: users' views of services. Londres: Macmillan, 1993.

ROSENBERG, M. G. The home is the workplace. In: CHAVKIN, W. (Ed.) Double Exposure. Nova Iorque: Monthly Review Press, 1984.

RUSSELL, D. Women, Madness \& Medicine. Cambridge: Polity Press, 1995.

SARTORIS, A. \& RAPELlA, E. Condiciones de la Salud Mental de la Mujer en Argentina. Buenos Aires, 1985. (Mimeo.)

SCAMBLER, A.; SCAMBLER, G. \& CRAIG, D. Kinship and friendship network and women's demand for primary care. Journal of the Royal College of General Practitioners, 26:746$750,1981$.

SHOWALTER, E. The Female Malady: women, madness and English culture (1830-1980). Londres: Virago, 1987. 
SPIRO, M. Some reflections on cultural determinism and relativism with special reference to emotion and reason. In: SHWEDER A. \& LEVINE, R. A. (Eds.) Culture Theory: essays on mind, self and emotion. Cambridge: Cambridge University Press, 1984.

STEPHENS, W. The Oedipus Complex: cross-cultural evidence. Nova Iorque: Free Press, 1962.

STRATHERN, M. Why is shame on the skin? Ethnology, 14:347-356, 1975.

TINKER, I. \& BRAMSEN, B. Women and World Development. Washington DC: Overseas Development Council, 1977.

USSHER, J. Women's Madness. Hemel Hempstead: Harvester Wheatsheaf, 1991.

WEISSMAN, M. \& KLERMAN, G. L. Sex differences and the epidemiology of depression. Archives of General Psychiatry, 24:98-111, 1977. 


\title{
8 \\ Histórias de Mulheres: reflexões sobre a maturidade e a velhice
}

\author{
Ana Zahira Bassit
}

O campo de investigação sobre o envelhecimento apresenta uma tendência predominante em sua abordagem, que o coloca em estreita relação com os processos de doença e a morte. Essa tendência teórica e metodológica, por ter predominância em relação às outras, dificulta a análise do envelhecimento de maneiras diferenciadas, que também possam favorecer sua associação com a saúde e a qualidade de vida.

A concepção de um curso de vida no qual a velhice é vivenciada apenas como perdas e limitações compromete o entendimento de outros cursos de vida, nos quais a velhice pode ser vivenciada de formas distintas. Podemos pensar em até que ponto a ênfase exclusiva nas perdas e limitações que a velhice pode proporcionar não é um exemplo de colonização do curso de vida (Featherstone, 1992). Nesse caso, um único curso de vida é configurado e imposto às outras pessoas que, apesar de terem a mesma idade cronológica, pertencem a diferentes grupos sociais.

Estudar o processo de envelhecimento na perspectiva de diferentes cursos de vida nos permite ampliar esse referencial de análise, tanto para os problemas existentes na área do envelhecimento como também para a delimitação e análise de novos problemas de investigação. Uma dessas possibilidades parece ser a inclusão de novas histórias de vida (Meihy, 1996) e depoimentos pessoais (Queiroz, 1988), entre outras formas de apreender a maneira pela qual as pessoas vivem o seu próprio envelhecimento em diferentes contextos sociais, culturais e históricos.

A contribuição que diferentes histórias de vida podem apresentar está pautada no pressuposto de que o envelhecimento é uma experiência diversificada e sujeita às influências de diferentes contextos sociais, históricos e culturais. Dessa forma, podem ser consideradas como um recurso metodológico importante, porque permitem apreender tanto a forma pela qual diferentes pessoas e grupos sociais envelhecem como a forma pela qual estes relatam suas experiências de vida. Nesta perspectiva, história de vida está sendo utilizada como sinônimo do conjunto de recursos metodológicos que tem a finalidade de apreender e registrar as experiências das pessoas durante o curso de suas vidas. Essas experiências podem ser caracterizadas por meio de eventos e outros episódios que singularizam a existência tanto das pessoas quanto de determinados grupos sociais. 
Para discutir como as histórias de vida contribuem para o estudo do envelhecimento, apresentamos histórias de mulheres nascidas entre os anos de 1922 e 1936, nas quais caracterizamos os eventos relacionados às formas pelas quais elas compreendem e vivenciam o seu próprio envelhecimento. Nosso objetivo é analisar como essas histórias favorecem a articulação de novos problemas de investigação para o campo do envelhecimento.

\section{Histórias de VIDA}

Mattos (1990) indica que nem sempre as expectativas dos especialistas em envelhecimento correspondem às demandas dos idosos ou ao próprio entendimento destes em relação ao seu processo de envelhecimento. Primeiro, porque os idosos têm uma representação muito mais positiva sobre sua condição do que a de alguns especialistas em envelhecimento. Segundo, porque existem diferenças significativas na forma como os idosos relatam suas experiências de vida, associadas às diferenças entre classes sociais, valores e tradição cultural. Os estudos desses autores sugerem a importância de se conhecer as necessidades e as experiências de vida dos idosos com base em seus próprios relatos, para verificar quais são os pontos de divergência ou convergência entre o discurso dos idosos, sujeitos, e o dos especialistas, autores da descrição do processo de envelhecimento.

Para Featherstone (1992), a análise do envelhecimento na perspectiva daqueles que envelhecem tanto atribui qualidade e especificidade aos dados levantados como pode contribuir para a diminuição do preconceito existente em relação àqueles que já ultrapassaram a marca dos 65 anos (Lorenzetto, 1998). Os depoimentos dos idosos sobre suas necessidades e experiências de vida favorecem a articulação de uma cultura sobre a velhice que, ao apresentar a diversidade e a complexidade dos cursos de vida daqueles que compõem este grupo social, pode ampliar este campo de conhecimento abrangendo novos problemas de investigação.

Öberg e Ruth (1995) consideram que a forma pela qual uma vida é vivida irá se refletir nos significados atribuídos à velhice, assim como as histórias de vida podem contribuir para o entendimento tanto de uma velhice bem-sucedida quanto de uma velhice problemática, com todas as suas disfunções. Para esses autores, as histórias de vida têm um significado especial para a gerontologia, porque tornam visíveis diferentes maneiras de viver, que atualmente nós conhecemos pouco, mas que num futuro próximo serão importantes para se entender outras histórias de vida, à medida que outras coortes alcançarem a velhice.

A história de vida nos oferece uma visão geral sobre a vida de uma determinada pessoa ou grupo de pessoas, que estão numa certa situação social, cultural e histórica. São construções da identidade, nas quais as pessoas nos contam quem elas são e como têm vivido as suas vidas (Rubinstein, 1988), sendo o self visto como o narrador, aquele que articula os diferentes eventos da vida numa história coerente (Polkinghorne, 1991).

Esses autores consideram a história de vida como uma construção, porque as pessoas não são simples depositárias de suas experiências, mas reconstroem as vidas quando nos contam suas histórias. Dessa forma, o passado não será lembrado como 
aconteceu, porque nossa recordação sobre os eventos sempre irá depender dos eventos subseqüentes, vistos do presente (Öberg \& Ruth, 1995).

Segundo Lalive d'Epinay (1995), a maneira pela qual uma pessoa vive a sua vidaé organizada com base em imagens e representações. No caso dos idosos, por exemplo, as representações que têm sobre o envelhecimento, a vivência de diferentes idades, as diferenças entre velho e jovem, morte, entre outras. Para o autor, a vivência das condições de vida de uma pessoa é sempre uma experiência subjetiva, porque é organizada segundo crenças, valores, representações e conceitos, que poderiam ser resumidos numa única palavra, ou seja, cultura. A história de vida apresenta, junto com a realidade objetiva, as concepções, valores e crenças do narrador. Portanto, a narrativa de idosos é influenciada pelo conceito que eles têm sobre si mesmos, sobre o envelhecimento e a velhice.

Lalive d'Epinay (1995) observa ainda que não existe um único conceito sobre os idosos, mas diferentes conceitos e imagens que estão relacionados a uma diversidade tanto cultural como individual. Uma mesma pessoa, durante a apresentação de sua história de vida, pode utilizar diferentes noções sobre o que é ser uma pessoa idosa ao se referir a si mesma. Assim, a história de vida é um exemplo de discurso peculiar, que apresenta uma variedade de formas pelas quais as partes do texto se unem para formar o conjunto da história e apresentam um discurso com um considerável significado cultural (Alasuutari, 1995).

Para Denzin (1970), a história de vida apresenta as experiências e as definições vividas por uma pessoa, grupo ou organização, indicando como esta pessoa, grupo ou organização interpreta a sua experiência. Podemos, portanto, inferir a diversidade de experiências existentes, se analisarmos essa definição de Denzin diante da variedade das definições sobre os idosos apontada por Lalive d'Epinay (1995).

Alasuutari (1995) indica que as informações que compõem a história de vida podem ser analisadas de diferentes maneiras e para finalidades distintas, sendo possível analisar apenas uma determinada parte da história ou um de seus temas. Minayo (1994) cita Denzin (1970) ao lembrar que as histórias de vida podem ser construídas tanto sobre todo o conjunto das experiências vividas por uma pessoa como também enfatizando um conjunto determinado de experiências.

\section{Mulheres e suas Histórias}

As histórias de vida desta pesquisa foram construídas com base no próprio depoimento de mulheres sobre as suas experiências de vida, no período de tempo compreendido entre os 20 anos e a idade que tinham na época em que foram entrevistadas, ou seja, entre 62 e 77 anos. Apesar das diferenças etárias, devemos lembrar que a idade cronológica por si só não é suficiente para explicar o envelhecimento, assim como é difícil precisar quando uma pessoa começa a envelhecer ou se torna um adulto. Dessa forma, enfatizamos os eventos e experiências da vida adulta dessas mulheres, que estavam relacionados com as formas pelas quais elas vivem o envelhecimento, sendo que estas podem ou não ter alguma correlação com a idade cronológica. 
Os depoimentos de vida foram obtidos por meio de entrevista aberta com enfoque em nosso interesse temático. As entrevistas foram realizadas individualmente, durante as quais as mulheres foram convidadas a relatar suas histórias. Antes de cada entrevista, foram explicados os objetivos do trabalho, a forma pela qual os dados seriam tratados e o nosso compromisso com a manutenção do anonimato desses depoimentos de vida.

As mulheres que participaram desta pesquisa são socialmente ativas e representam um período etário no qual a diversidade de vivências permite caracterizá-las como uma categoria boa para fazer pensar em questões biopsicossociais. Entrevistamos 13 mulheres com idades distribuídas da seguinte forma: 62 anos (1 mulher), 64 anos ( 2 mulheres), 65 anos ( 3 mulheres), 68 anos ( 1 mulher), 70 anos ( 2 mulheres), 71 anos ( 1 mulher), 72 anos ( 2 mulheres) e 77 anos ( 1 mulher). Quanto ao estado civil, encontramos sete viúvas, uma casada, três solteiras e duas separadas.

Partimos do conceito de mulheres socialmente ativas, que pressupõe algum grau de participação na comunidade, e procuramos encontrá-las em grupos destinados à terceira idade. Dois grupos, em especial, nos chamaram a atenção: um localizado na periferia e outro na região dos Jardins, em São Paulo. Consideramos que esses grupos nos permitiriam verificar diferenças socioculturais entre os depoimentos de mulheres de classes populares e altas. Entrevistamos também outras mulheres que não participam de nenhuma atividade comunitária, para evitar possíveis vieses quanto à influência do grupo em sua compreensão e vivência do processo de envelhecimento. Encontramos essas mulheres por meio da indicação de amigos e/ou conhecidos.

O número de mulheres entrevistadas foi determinado em função do critério de "saturação ou de reincidência de informações" (Minayo, 1994:102), ou seja, à medida que os dados das entrevistas permitiram delimitar a relação entre os objetivos e o quadro empírico, decidimos interromper o processo de coleta de dados.

Nos depoimentos, consideramos como evento todos os acontecimentos previsíveis e imprevisíveis que pudessem estar relacionados com as formas pelas quais a vida dessas mulheres se desenrolaram, como, por exemplo, casamento, divórcio, viuvez, filhos, entre outros. Consideramos também os acontecimentos que os antecederam e os que lhes foram subseqüentes.

Para a análise dos depoimentos, realizamos uma leitura flutuante, a fim de conhecer exaustivamente as vidas que nos foram relatadas. Verificamos se as informações obtidas eram suficientes para atingir os objetivos da pesquisa, como também os temas que emergiram desses depoimentos e aqueles que estavam relacionados ao processo de envelhecimento e à idade adulta.

\section{Diferentes Maneiras de Envelhecer}

As mulheres que participaram desta pesquisa nasceram num período de intensificação dos processos de urbanização e industrialização da sociedade brasileira. Campos (1998) aborda as raras possibilidades oferecidas às mulheres daquela época, em 
que o casamento era de vital importância para as suas vidas, porque eram consideradas fundamentalmente como 'mães' e 'esposas'.

De acordo com essa autora, apesar de o voto feminino ter sido garantido em 1932, o casamento ainda continuou a ser quase que a única opção de vida para as mulheres da classe alta, como possibilidade de sustento, proteção e reconhecimento social; a outra possibilidade era entrar para uma congregação religiosa. No entanto, as mulheres de classe social mais baixa, em função da adversidade de suas vidas, eram mais preparadas para desenvolver atividades que pudessem garantir o seu sustento e, muitas vezes, também o de suas famílias (Campos, 1998).

Com exceção de Lúcia, que nasceu na cidade de São Paulo, as outras mulheres desta pesquisa nasceram em diferentes estados brasileiros ou no interior do estado de São Paulo. A mudança para a capital paulista, na maioria dos casos, foi opção de suas famílias, com a finalidade de obter melhores condições de trabalho e também como uma oportunidade para morar junto com os familiares que já estavam morando na capital. Com exceção das mulheres solteiras e de Carmen e Márcia, que se casaram com 34 e 50 anos, respectivamente, a maioria das outras mulheres se casou em torno dos 20 anos de idade. Em seus depoimentos, observamos que o papel da família, ou de pessoas mais velhas que assumiram a responsabilidade por suas vidas, foi de extrema importância como agenciador de seus casamentos, bem como para a sua introdução no mundo do trabalho.

Com exceção de Lúcia, que só começou a trabalhar depois da separação conjugal, todas as outras iniciaram as atividades antes do casamento, ou para ajudar as famílias, em vários casos, ou para ajudar a pagar os estudos, como no caso de Carmen. Essas mulheres continuaram a trabalhar depois do casamento a fim de ajudar a manter as suas próprias famílias. O trabalho influenciou fortemente a trajetória de suas vidas, o que pode ser observado em muitos depoimentos. Suas vidas são contadas com expressões como, por exemplo, "uma vida de muito trabalho", "vida sacrificada", "fui escrava do trabalho", "eu sempre trabalhei”, entre outras. No entanto, poucas, como Ana, Nair, Carmen e Lúcia, indicaram alguma satisfação com o trabalho, porque conseguiram desenvolver suas carreiras profissionais ou porque trabalharam no que gostavam de fazer.

Esses resultados coincidem com estudos similares (Campos, 1998), que indicam que o trabalho na vida das mulheres das camadas populares está associado à necessidade de ajudar as famílias quando ainda são solteiras, em função da ausência e/ou morte do pai, seguida da necessidade de contribuir com o orçamento de suas próprias famílias depois de casadas. O trabalho dessas mulheres foi realizado simultaneamente ao cumprimento das atribuições de mãe e esposa, fato apontado nos depoimentos como uma sobrecarga de atividades.

À semelhança do que aponta o estudo de Campos (1998), a maioria das mulheres que entrevistamos pertence a classe sociais 'mais baixas' ou 'populares', com exceção de Lúcia, Carmen e Nair, que pertencem a classes sociais 'mais altas'. Em termos de educação formal, Lúcia, Ana, Nair e Carmen são as mulheres com maior número de anos de estudo. Nair e Carmen freqüentaram universidade, enquanto as mulheres da classe baixa apenas conseguem assinar o seu próprio nome. Esse fato está associado à con- 
cepção, vigente naquela época, de que as mulheres não precisavam estudar porque sua função principal era cuidar da casa, dos filhos e da família. Conseqüentemente, as atividades de trabalho que desenvolveram foram de baixa remuneração e não apresentaram nenhuma possibilidade para desenvolver uma carreira profissional ou uma identidade profissional.

Em muitos depoimentos, as mulheres consideraram a família como um obstáculo tanto para o prosseguimento dos estudos quanto para a entrada em um convento, o que acarretou a sua exclusão dos processos de educação formal, bem como dificultou o acesso ao mercado de trabalho formal e, conseqüentemente, a melhores oportunidades de trabalho (Campos, 1998).

As mulheres casadas que entrevistamos iniciaram os depoimentos a partir de seus casamentos e do nascimento do primeiro filho. Carmen, no entanto, apesar de casada, começa a sua história a partir da sua fase de estudos, da universidade e do trabalho. Por sua vez, as solteiras iniciaram os relatos a partir de sua convivência com as famílias de origem. Esses resultados coincidem com outros estudos (Haldemann, 1995) que indicam que as mulheres dessa coorte começam os seus depoimentos falando dos elementos constitutivos da sua identidade como mulheres adultas de seu grupo de referência e de sua época, ressaltando o casamento, a constituição de suas próprias famílias e o nascimento dos filhos.

Para as que permaneceram solteiras, os depoimentos também confirmam os valores morais de seus grupos de referência, dando ênfase à virgindade como valor máximo da época para mulheres não casadas, dizendo que mantêm as suas vidas 'imaculadas', ou seja, sem atividade sexual alguma. Apenas uma das mulheres solteiras de classe alta disse que mantém atividade sexual mesmo não sendo casada. As mulheres solteiras também reafirmaram os cuidados e a dedicação às suas famílias de origem como valores morais da época, como no caso de Joana, que cuida de uma sobrinha-neta, ou de Ana, que assumiu para si os cuidados de uma família que não é a sua de origem.

O ideal do casamento, a constituição de sua própria família e os filhos representam os elementos que possibilitaram a reafirmação de suas identidades como mulheres adultas daquela época, ou seja, como 'cuidadoras' dos maridos, dos filhos, da família, de suas casas e dos outros. Campos (1998) observa um fato interessante na expressão da identidade dessas mulheres. Nas suas narrativas, elas não especificam suas funções como 'esposas', talvez porque acreditem que o marido, como adulto, necessite apenas de seus cuidados essenciais, como, por exemplo, a alimentação e a roupa, ou maior dedicação no caso de doença e/ou invalidez.

Igualmente, corroborando Campos (1998), para algumas dessas mulheres, o desenvolvimento das relações amorosas entre os casais não constituiu o aspecto mais importante do casamento. Apenas em algumas das histórias de vida foi possível apreender sinais de uma convivência favorável entre essas mulheres e seus maridos, assim como houve poucas indicações de que estavam ou eram apaixonadas por eles. Márcia, por exemplo, diz que gosta do marido apesar das bebedeiras. Georgina, Maria das Graças e Rosário falam da importância de seus maridos para a constituição de suas vidas como mulheres adultas. Carmen e Lúcia, por sua vez, mencionaram estar apaixonadas pelos maridos. 
A caracterização das mulheres como ‘cuidadoras' dos outros foi unânime. Marcia, por exemplo, relata que aceitou se casar com o seu marido porque ele tinha filhos pequenos que precisavam ser cuidados. Maria das Graças conta que na doença do marido, quando ela estava cuidando dele, "não tinha queixa dele, não". Maria José, por sua vez, mesmo abandonada pelo seu segundo marido, continuou a tomar conta de um dos filhos e do neto dele.

Outro aspecto a ser observado nos depoimentos é o pequeno interesse pela procura de um novo companheiro, após a morte e/ou a separação do marido. Várias dessas mulheres responderam que não tiveram tempo para um novo investimento amoroso, ou porque estavam envolvidas em outras atividades, no trabalho, ou ainda porque seus filhos, noras e genros recriminavam este tipo de comportamento. Algumas das viúvas também argumentaram com as dificuldades de seus primeiros casamentos, dizendo que estas não as estimularam a repetir a experiência.

No grupo específico de entrevistas, o desenrolar de suas vidas não se restringiu à dependência de terceiros - nem da autoridade do pai, nem de outras figuras masculinas e nem, atualmente, da cobrança dos filhos, genros/noras e netos -, embora tal dependência fosse a tônica na vida das mulheres. O depoimento de Ana é ilustrativo dessa dependência: segundo ela, para se casar naquela época, era necessário ter uma família, ou alguém mais velho, que pudesse tanto encontrar como aprovar o noivo. Hoje, existe a tentativa de cerceamento ainda muito forte, como se detecta nos depoimentos de Maria José sobre os filhos que não a deixam dançar, ou no de Georgina, quando conta que o marido brincava com ela dizendo: "Olha, eu te tirei lá da casa da mulher, mas agora eu sou o seu pai e sua mãe, porque eu sou mais velho".

Campos (1998) observa e nós constatamos na pesquisa que, em alguns casos, as viúvas e/ou as separadas consideram a ausência do marido como libertação, que lhes permite dar vazão aos seus próprios sentimentos e opiniões. Maria (viúva) expressa isso quando diz: "Depois de velha eu estou tendo o que eu não tive antes".

Igualmente, Lúcia refere-se à reconquista de sua autonomia quando menciona que só voltou a trabalhar depois de alguns anos após a separação do marido.

A maioria das mulheres desta pesquisa apontou a importância de se manter em atividade e em contato com os outros, e tal disposição coincide com os aspectos encontrados por Haldemann (1995). Essa autora assinala que as mulheres dessa faixa etária estão mais interessadas em manter suas relações pessoais do que em qualquer outro projeto. Tal perspectiva pode estar indicando a necessidade de suprir a ausência do marido e/ou companheiro ou a falta de contato mais frequiente com os filhos, mas também pode indicar uma certa libertação da função de cuidadora.

As palavras 'abandono' e ‘solidão' foram utilizadas para descrever o envelhecimento, o que pode estar indicando problemas atuais de perdas de referenciais tradicionalmente constituídos, que as deixaram sem amigos, com muitas restrições para cultivar amizades, lazer ou recreação. Os depoimentos de Ana, Nair, Carmen e Lúcia diferem dos demais porque definem o envelhecimento de uma forma mais positiva, têm amigos e desenvolvem atividades de lazer. Podemos ponderar, portanto, que a ênfase em manter alguma atividade, principalmente de lazer, sinaliza uma necessidade de suprir carências que foram se acumulando ao longo de suas vidas. 
Embora existam algumas tendências gerais, como as até aqui assinaladas, no modo de essas mulheres levarem a vida e reagirem aos problemas que enfrentam e enfrentaram, há diferenças entre as preferências quanto às atividades que gostariam de desenvolver. Carmen acumulou uma lista de coisas que gostaria de fazer em sua aposentadoria e diz que não se sente sozinha; ao contrário, aproveita os momentos em que pode ficar consigo mesma. Ana participa de diversos grupos, desenvolve diferentes atividades e gosta de estudar. Nair gosta de viajar e ainda continua trabalhando. Joana não gosta nem de bordado nem de crochê, mas freqüenta escola à noite, enquanto Lúcia aproveita tanto os momentos em que está com a sua família como aqueles em que está sozinha para recordar as viagens que já fez.

Essas diferenças indicam que, para essas mulheres, a organização de atividades, principalmente em grupos de terceira idade, deve considerar tanto as suas preferências individuais quanto as que estão relacionadas ao desenrolar de suas vidas adultas. Um dos temas centrais que emergiram de suas histórias é o da velhice e da aposentadoria como eventos que podem ser vivenciados positivamente em novas descobertas e realizações. Isso é mais do que afirma Lorenzetto (1998:113) em sua observação: "vivenciar o Tempo Livre, como uma apropriação específica da Terceira Idade, estava vinculado a um voltar-se reflexivo para o eu interior, para si - o que até então não era possível ou permitido". Mas se adapta ao que a autora acrescenta: "na Terceira Idade ocorre a descoberta de um tempo que é reinventado e que se volta para o futuro".

Observamos que essas mulheres procuram desenvolver atividades que não tiveram a oportunidade de realizar anteriormente: a conversa com os amigos para algumas, o crochê para outras, a possibilidade de se dedicar às suas recordações, as viagens e muitas outras. Suas trajetórias levam a concluir que a velhice pode ser considerada como um período oportuno para se dedicarem a si mesmas, como um espaço para um processo reflexivo, assim como uma etapa de alta produtividade material, social e moral e de conquista de autonomia.

As mulheres que freqüentam o grupo de terceira idade valorizam-no como espaço para encontro de novas pessoas e de novas amizades. Muitas também incluem as práticas religiosas como importantes nas suas vivências positivas e libertadoras. No entanto, Nair, Carmen e Lúcia não participam de grupos de terceira idade, mas se reportam aos amigos e a outros grupos de interesse e de referência como fundamentais. Isso indica que o mais importante para elas não é o formato do grupo, mas sim o que conseguem extrair das atividades que desenvolvem com os outros, com as suas famílias, com os seus pares e por si mesmas.

A maioria das mulheres que entrevistamos não falou do envelhecimento como objeto de suas maiores preocupações - embora, obviamente, falassem dos sinais do tempo em seus corpos, como, por exemplo, rugas, perda de resistência, entre outros. Apenas Carmen e Lúcia disseram que se prepararam para a aposentadoria e para a velhice, respectivamente. Ana menciona que, conforme envelhecia, observou que foi aprendendo mais. As outras revelaram não ter desenvolvido nenhuma preocupação nesse sentido, mesmo aquelas que consideraram o envelhecimento como abandono e solidão. 
Embora o grupo etário dessas mulheres represente o alvo das preocupações dos especialistas em envelhecimento, especialmente os da área médica, e apesar de terem relatado alguns problemas de saúde, esses também não constituíram o foco de atenção de seus depoimentos. Seu conceito de saúde corresponde ao senso comum para sua idade, ou seja, são saudáveis se nada inviabiliza a sua locomoção e/ou a realização de suas atividades, com autonomia e independência. Mesmo no caso de Maria José, que teve um derrame, ou de Conceição, que teve complicações sérias durante o parto, não houve, nos depoimentos, uma ênfase em doenças. Isso não impede que teçamos alguns comentários sobre sua concepção de prevenção e promoção, ou melhor dizendo, sobre a forma como cuidam da saúde.

O primeiro aspecto a ser considerado é a característica que as identifica como cuidadoras dos outros e até que ponto esta característica não dificulta que também tenham preocupação com a sua própria saúde, passando de cuidadoras dos outros a cuidadoras de sua própria saúde e de si mesmas. O segundo aspecto está relacionado com a dependência dos outros, com o fato de ficarem à espera de terceiros para tomarem providências quanto à sua saúde. Georgina, por exemplo, diz: "Eu pelo menos fui uma pessoa que toda a vida tive muita saúde. Hoje os meus filhos não precisam estar dizendo "vai ao médico"".

O terceiro aspecto está relacionado ao fato de que muitas definem o envelhecimento como doença; daí, como não estão doentes, elas não são velhas e, portanto, não precisam de nenhuma atenção médica especial, mesmo que seja apenas para a prevenção de alguns doenças, que eventualmente podem aparecer nesse período etário. Apenas Conceição diz que "a gente tem continuar sempre fazendo um tratamento de saúde, procurar uma igreja para poder ficar mais aliviada".

A finitude da vida parece ser encarada com uma certa naturalidade, conforme o referencial religioso que governa suas vidas, o qual parece contribuir para uma aceitação quase que pacífica do declínio e do fim de seus corpos, mas, mesmo assim, ainda com a idéia presente de que é necessário continuar lutando e "não se entregar e não ficar mole".

Os depoimentos não nos permitem avançar muito no entendimento dessa questão, porque ela não constituía o nosso principal foco de interesse, mas, certamente, esse aspecto revelado poderá ser um dos pontos pesquisados em outros trabalhos. Podemos, no entanto, apresentar algumas considerações quanto às relações entre a forma como elas concebem o envelhecimento e suas percepções sobre as suas condições de saúde e dos cuidados que é preciso ter para mantê-la, bem como sobre a forma como lidam com a finitude de seus corpos.

Para Lalive d'Epinay (1995), o envelhecimento pode ser considerado como exclusão da vida normal quando perdemos os significados que caracterizavam a nossa vida e ainda não pode ser caracterizado como morte, mas sim como um período de transição entre a vida que tínhamos e a nossa morte. De acordo com esse autor, a exclusão da vida normal pode ser caracterizada pela ausência do trabalho, pela falta de prazer na vida, pela falta de relações familiares e pela ausência de saúde, entre outros aspectos. 
Em diferentes narrativas, observamos que a saúde é considerada como condição necessária e fundamental para se ter uma vida normal. Tal consideração pode estar relacionada à crença de que a vida em si mesma é uma evidência absoluta de nossa existência, talvez uma de nossas poucas certezas, na qual a saúde surge como um fim em si mesmo (Lalive d'Epinay, 1995). Algumas das mulheres desta pesquisa definiram o envelhecimento por meio de sua negação, dizendo:

Não existe envelhecimento, só existe doença.

É esse pessoal que fica parado, não se desenvolve em nada.

O envelhecimento é quando você perde a saúde e não dá para você fazer mais nada.

Suas sugestões para os que estão envelhecendo passam por questões que envolvem desde "a fé em Deus" até a luta contínua contra a adversidade da vida: "Só que a gente tem que lutar até o dia que Deus quiser".

Nesses termos, o envelhecimento é equiparado à doença e à ausência de movimento e/ou de ação, o que o coloca em direta oposição à saúde e ao próprio movimento da vida. A responsabilidade de continuar vivendo parece estar muito mais nas mãos das próprias pessoas, ou nas de Deus, do que na possibilidade de manter a saúde, a independência e a autonomia no envelhecimento. Essa é a situação da maioria, quase absoluta, das mulheres entrevistadas.

Ao tomarem as doenças como uma das características definidoras do envelhecimento, essas mulheres negam este processo porque se sentem saudáveis. Conseqüentemente, tanto não reconhecem diferenças entre os padrões de envelhecimento primário, secundário ou terciário e o patológico como também reproduzem o discurso de alguns especialistas em envelhecimento.

É certo que observamos diferenças entre a forma pela qual definem o processo de envelhecimento e as maneiras como o vivenciam. Suas definições parecem estar mais relacionadas aos seus próprios receios e temores do que à forma como estão vivendo esse período em suas vidas. Portanto, se pensarmos na necessidade de implantar medidas que possam manter e implementar a condição de saúde dessas mulheres, devemos considerar tanto a forma como concebem quanto as maneiras como estão vivendo o envelhecimento.

A perspectiva é de que o envelhecimento deve ser compreendido como um período integrado a toda a existência vivida, na qual a velhice recebe diferentes significados em relação à vida inteira de uma pessoa (Öberg \& Ruth, 1995). Nesta linha de reflexão, Veras (1995:21-22) considera que "as medidas preventivas, para se tornarem plenamente eficazes, devem começar na infância e continuar na vida adulta. Contudo, nem sempre isto é possível, e, algumas vezes, só é possível tomar-se alguma providência já na velhice".

Para exemplificar essas afirmações, pode-se citar o fato de que a maioria das mulheres entrevistadas não recebeu nenhuma orientação sobre como manter a sua própria saúde ou se preocupou em cuidar do próprio corpo, assim como não teve nenhuma informação sobre a reprodução e o comportamento sexual. Esses fatos vividos de maneira tradicional caracterizam a relação dessas mulheres com a saúde, aqui 
entendida como a ausência de doença. Igualmente, os aspectos relacionados à prevenção refletem suas concepções sobre o próprio corpo, por meio de noções que foram construídas no desenrolar de suas vidas.

Tais costumes que se reproduzem no cotidiano especificam os cuidados que essas mulheres demandam em termos de prevenção e promoção de sua saúde. Elas sentem dificuldade em discutir a prevenção porque parecem acreditar que a saúde é apenas uma dádiva de Deus, e só recorrem aos serviços de saúde quando estão muito doentes, o que significa que a sua autonomia e a sua independência já estão em risco.

Podemos dizer que existe uma distância significativa entre a visão dessas mulheres e os conceitos dos especialistas em envelhecimento, especialmente os da área médica. As orientações dos especialistas voltam-se mais para os que já estão doentes do que para com aqueles que ainda têm condições de manter e preservar a sua autonomia e independência por mais algum tempo. Além disso, a medicalização do envelhecimento dificulta aceitar a contribuição dos próprios idosos que têm uma outra perspectiva.

Em relação à forma pela qual descrevem o processo de envelhecimento, observamos que algumas mulheres o definiram como tempo de solidão, abandono e desvalorização, por parte tanto da sociedade quanto dos amigos e da família: "Primeira coisa que eu tenho revolta na velhice é que ninguém dá valor em você”.

Outro aspecto observado é que o envelhecimento foi entendido também como exclusão do prazer em suas vidas, como mostra Márcia ao dizer que só começou a envelhecer quando perdeu seu marido: "Sinto falta do marido, sinto falta do prazer, isso aí..."

O envelhecimento, como período de exclusão, pode ser entendido a partir da perda de espaço dos significados e valores que anteriormente estruturaram suas vidas e que hoje não são suficientes para reorganizar sua velhice. Daí o movimento de negar a própria velhice, tanto por sua associação com doenças, uma vez que não estão doentes, não são velhas, como também de torná-la objeto de reflexão: "Acho que velha é essas que se entregam. Eu acho que velhice vai da pessoa que se entrega, que fica com aquela coisa..."

No entanto, se compararmos suas definições com a forma como estão vivendo o envelhecimento, podemos observar que, apesar de relatarem algumas das perdas previsíveis no envelhecimento, a maioria se considera feliz e está satisfeita com as atividades que desenvolvem. Tal satisfação talvez tenha como fonte o contato com outras pessoas, nos grupos de terceira idade, na igreja, ou com amigos e familiares, o que favorece a reorganização de suas existências com base em outros valores e significados. Conceição, por exemplo, não quer ser mais pajem ou esposa; ela quer ser "uma mulher livre", talvez livre dos antigos valores, significados e eventos que tornaram a sua trajetória de vida tão sofrida. Assim, ela se "sente mais alegre, mais comunicativa que quando era jovem...", e exemplifica: "Hoje, graças a Deus, eu tenho amizade com os padres, amizade com qualquer pessoa, e a velhice é para isso".

A maioria reconhece tanto as perdas como os ganhos do processo de envelhecimento, com algumas variações individuais quanto ao peso atribuído às perdas ou aos ganhos. Igualmente, apresentam sugestões positivas para aqueles que estão envelhecendo, sinalizando uma preocupação com o presente e com o futuro maior do que com o passado. Nair, por exemplo, considera que "no mundo todo mundo sofre, todo mundo 
tem alegria. Quanto mais você observar e for inteligente para ver as coisas maravilhosas que estão em volta de você, mais você vê que o mundo é belo”. E Maria das Graças dá o seguinte conselho: "Que não se entregue à velhice, que a gente tem mais que continuar a viver".

Os depoimentos de Ana, Carmen e Lúcia devem ser destacados desse contexto, porque foram as únicas mulheres que descreveram o envelhecimento com base em outros indicadores que não a saúde, a solidão e o abandono. Lúcia, por exemplo, considera o envelhecimento "uma boa experiência", porque se sente realizada com a sua vida. Carmen está sendo surpreendida com os aspectos bons da velhice, como, por exemplo, maior segurança, tranqüilidade e a possibilidade de curtir a vida. Ana considera que envelhecer é aprender para depois poder transmitir seus conhecimentos, e vê no envelhecimento uma possibilidade de trocar informações com os outros.

Lúcia e Carmen consideram que se prepararam para a velhice, ao contrário de Ana, que diz: "Não tenho do que me queixar, não, porque conforme a idade ia chegando eu ia melhorando no serviço, eu ia aprendendo, progredindo, ganhando conhecimento".

Essas três mulheres também consideram que são felizes e não se sentem sozinhas. Lúcia considera ter duas alegrias na vida: "Quando chegam pessoas da minha família e quando vão embora e eu posso ficar sozinha, descansando".

A vida dessas três mulheres foi organizada e configurada de uma forma distinta das demais, apesar das semelhanças existentes em relação às outras, quanto aos valores e costumes de sua época. Tiveram acesso a outras informações, a outros grupos de referência, a diferentes valores e culturas. Ana, por exemplo, teve os colegas de estudo, Carmen conviveu com alunos e Lúcia atendeu pessoas enquanto era secretária.

Contatos e informações foram fundamentais para acrescentar a suas vidas outros valores e significados. Contribuíram para que o patamar de suas relações ultrapassasse os valores tradicionais da família, do trabalho e do casamento, o que repercutiu na vivência do envelhecimento de uma forma distinta das demais. Consideramos que essa distinção pode ser caracterizada pela independência dessas mulheres em relação a terceiros, bem como pela satisfação que sentem por terem realizado e estarem realizando seus planos e sonhos. Esses fatos as colocam na posição de cuidadoras de si mesmas, além de cuidadoras dos outros.

Campos (1998) considera que as questões de gênero são preponderantes em relação às de classe social na determinação do habitus que governa a vida dessas mulheres. De fato, em suas narrativas, as mulheres se reportam mais aos costumes de sua época e à sua condição de gênero do que à sua classe social. No entanto, se considerarmos que as questões de gênero são, essencialmente, delimitadas a partir da classe social dessas mulheres, podemos discordar de Campos.

Os resultados encontrados nesta pesquisa corroboram os de Neri (1999a:12), para quem "as oportunidades educacionais e sociais, a saúde física e mental e o estilo de vida têm um papel importantíssimo na determinação do ritmo e dos produtos do envelhecimento". Igualmente para a definição sobre qualidade de vida na velhice como "produto de uma adequada interação de fatores individuais e socioculturais, entre os quais as oportunidades educacionais ao longo do curso de vida desempenham um papel fundamental" (Neri, 1999b:16). 
O envelhecimento deve ser considerado como uma questão de classe social, que também é permeada por questões de gênero. As diferenças entre os depoimentos de Ana, Carmen e Lucia e os das outras mulheres relacionam-se à classe social e ao tempo de escolaridade, o que também não deixa de ser uma diferença de classe. Esses depoimentos apresentam novos problemas para o campo do envelhecimento, na medida em que sinalizam a importância da educação - tanto a formal quanto a informal - para a vivência de uma velhice com qualidade de vida, como também de outras informações que possam promover a saúde desses grupos sociais.

Os resultados desta pesquisa apontam para o fato de que é importante dar ênfase aos relatos de pessoas para mostrar como, por pertencerem a diferentes grupos sociais, suas trajetórias de vida foram influenciadas de forma distinta pelo mesmo conjunto de eventos históricos e culturais.

A análise das histórias relatadas apontou semelhanças quanto aos significados que caracterizaram as suas vidas e também destacou as diferenças na vivência dos eventos que marcaram a sua época. Observamos que os eventos que contribuíram para diferenciar suas histórias de vida estavam intrinsecamente atrelados ao próprio desenrolar de suas vidas, o que indica que o curso de vida também é uma perspectiva importante na compreensão da trajetória das pessoas. Esta perspectiva mostra que a existência de cada pessoa é influenciada tanto por aspectos sociais, culturais, econômicos e históricos como por características biológicas, psicológicas e do meio ambiente.

As mulheres que consideraram o envelhecimento como negação da vida normal organizaram as suas vidas com base em papéis tradicionais, desempenhados na família e no trabalho. Suas vidas foram delimitadas em função da esfera reprodutiva e de parentesco, inclusive o trabalho. As diferenças que apontaram em relação à percepção de períodos distintos no curso de suas vidas estavam relacionadas ao casamento e à sua possibilidade de gerar filhos. No caso das solteiras, a família ainda continuou a ser o foco de significado de suas vidas.

A vivência do envelhecimento compreendida como exclusão da vida normal contribuiu para segregá-las em um grupo social identificado pela dependência em relação tanto à família como a terceiros. No entanto, anunciando sinais de um novo tempo, até mesmo esse grupo se pôs a lutar por uma posição na qual as mulheres não se sintam abandonadas pela família, pelos amigos e pela sociedade - fato que indica um período de transição dos valores que configuraram a sua vida adulta para uma nova atitude que gostariam de afirmar no presente. Portanto, cabe questionar até que ponto o discurso dos especialistas em envelhecimento, ao enfatizar a dependência na velhice, não está com exceção dos casos de incapacidade física e mental - contribuindo para a segregação desse grupo social. Se assim for, ele representa um obstáculo à vivência da velhice com base em outros parâmetros que não as perdas.

Nossos resultados permitem concluir que o envelhecimento não pode ser considerado apenas como sinônimo de doença ou que seu estudo não pode ser reduzido à categoria 'dependência'. A velhice é um período que dá continuidade à vida adulta e pode ser vivenciada de uma forma satisfatória (Guimarães, 1998). Portanto, é necessário positivar o envelhecimento e a velhice, pois fazem parte de nossa existência, desde que não morramos prematuramente. Para tanto, na organização de serviços dirigidos aos 
idosos, os especialistas devem começar a considerar também o discurso de idosos que vivem o envelhecimento com qualidade de vida e o concebem como uma experiência positiva.

As histórias de Ana, Carmen e Lúcia podem ser consideradas como exemplos para algumas das características das sociedades pós-modernas, principalmente se considerarmos a fragmentação e a multiplicidade de identidades e selves que compõem a vida dessas mulheres. A diferença entre as suas histórias de vida e as das demais reside, sobretudo, na oportunidade que tiveram de acesso a diferentes grupos sociais, diferentes oportunidades, diferentes experiências e a culturas distintas - fato que enfatiza a necessidade de maior autonomia feminina em relação ao universo restrito do lar, de seu engajamento social, de intensificação dos relacionamentos, como também de ampliação da educação formal da mulher.

As mulheres participantes desta pesquisa, apesar de toda a adversidade de suas vidas, apresentaram alternativas para a vivência de uma velhice com qualidade de vida, alegria e satisfação. Suas histórias contribuem para ampliar nossa compreensão sobre o processo de envelhecimento e sobre o fato de que as necessidades reveladas em suas narrativas podem articular novos problemas para este campo de investigação. Considerando que o envelhecimento é uma questão de classe social, permeada por questões de gênero, podemos concluir que ainda há muito o que estudar em relação às diferentes representações, significados, conceitos e definições sobre o processo de envelhecimento, que estruturam as experiências de vida de homens e mulheres de diferentes grupos sociais.

\section{ReferênCIaS Bibliográficas}

ALASUUTARI, P. Researching Culture: qualitative method and cultural studies. Londres: Sage, 1995

CAMPOS, M. C. S. S. Women in São Paulo in the family and in the work market: behavior and representations. In: KALEKIN-FISHMAN, D. (Ed.) Designs for Alienation. Sophi: University of Jyväskyla, 1998.

DENZIN, N. K. The Research Act. Chicago: Aldine Publishing Co., 1970.

FEATHERSTONE, M. The life course: body, culture and imagery in the ageing process. In: WADA, S. (Ed.) Studies on the Social and Cultural Background of the Image of Ageing. Tóquio: Waseda University Press, 1992.

GUIMARÃES, M. C. T. V. Velhice: perda ou ganho. Arquivos de Geriatria e Gerontologia, 2(2):52-59, 1998.

HALDEMANN, V. Older immigrant women in Montreal. [Sierre: IMAGES OF AGING CONFERENCE, II, 1993] In: HUMMEL, C. \& LALIVE D'EPINAY, C. (Eds.) Images of Aging in Western Societies. Genebra: Centre for Interdisciplinary Gerontology/Université de Genève, 1995. 
LALIVE D'EPINAY, C. Images of aging in autobiographical narratives of elderly. [Sierre: IMAGES OF AGING CONFERENCE, II, 1993] In: HUMMEL, C. \& LALIVE D'EPINAY, C. (Eds.) Images of Aging in Western Societies. Genebra: Centre for Interdisciplinary Gerontology/Université de Genève, 1995.

LORENZETTO, M. A. As Senhoras do Tempo. São Paulo: Texto Novo, 1998.

MATTOS, F. M. Velha é a Vovozinha: identidade feminina na velhice, 1990. Dissertação de Mestrado, Porto Alegre: PPGAS, Universidade Federal do Rio Grande do Sul.

MEIHY, J. C. S. B. Manual de História Oral. São Paulo: Loyola, 1996.

MINAYO, M. C. de S. O Desafio do Conhecimento: pesquisa qualitativa em saúde. 3.ed. São Paulo, Rio de Janeiro: Hucitec, Abrasco, 1994.

NERI, A. L. O Fruto Dá Sementes: processos de amadurecimento e envelhecimento. Campinas: Unicamp, 1999a. [Texto em fase de elaboração, circulação restrita.]

NERI, A. L. Qualidade de Vida na Velhice e Atendimento Domiciliário. Campinas: Unicamp, 1999b. [Texto no prelo. Cópia de circulação restrita ao Curso de Pós-Graduação em Gerontologia da Unicamp.]

ÖBERG, P. \& RUTH, J-E. Old age as reflected in the life stories of elderly finns. [Sierre: IMAGES OF AGING CONFERENCE, II, 1993] In: HUMMEL, C. \& LALIVE D’EPINAY, C. (Eds.) Images of Aging in Western Societies. Genebra: Centre for Interdisciplinary Gerontology/Université de Genève, 1995.

POLKINGHORNE, D. E. Narrative and self-concept. Journal of Narrative and Life History, 1(2-3):135-153, 1991.

QUEIROZ, M. I. P. Relatos orais: do ‘indizível’ ao ‘dizível'. In: VON SIMSON, O. M. (Org.) Experimentos com Histórias de Vida: Itália-Brasil. São Paulo: Vértice, Editora Revista dos Tribunais, 1988.

RUBINSTEIN, R. L. Stories told: in-depth interviewing and the structure of its insights. In: ROWLES, G. \& REINHARZ, S. (Eds.) Qualitative Gerontology. Nova York: Springer Publ. Co., 1988.

VERAS R. P. \& CAMARGO, J. R. K. R. Idosos e universidade: parceria para a qualidade de vida. In: VERAS, R. P. (Org.) Terceira Idade: um envelhecimento digno para o cidadão do futuro. Rio de Janeiro: Relume-Dumará, Unati/Uerj, 1995. 


\section{9 \\ 0 Idoso sob o Olhar do Outro \\ Edinilsa Ramos de Souza, Maria Cecília de Souza Minayo, Liana Furtado Ximenes \& Suely Ferreira Deslandes}

Este trabalho foi realizado com o objetivo de observar o olhar da imprensa e, sob sua ótica, a concepção da sociedade a respeito da categoria 'idoso'. Não se pretendeu realizar um estudo teórico dessa categoria, mas sim estabelecer uma análise do discurso sobre acontecimentos do cotidiano veiculado por alguns jornais.

A primeira questão que ressalta é a idéia, no imaginário retratado pela imprensa, de 'idoso' como pobre e como problema social. Ou seja: ficou muito clara neste estudo a visão constatada por Peixoto (2000) na literatura francesa de que, nas sociedades modernas, o 'idoso como problema' é parte da situação da classe trabalhadora em geral, acirrando-se nos seus segmentos mais miseráveis. Os velhos considerados 'problemas' são os mesmos que usam os serviços públicos da saúde, que dependem da aposentadoria do INSS ou não têm direito à aposentadoria, e os que usam os serviços de assistência social pública.

As classes privilegiadas, ao contrário, se colocam individualmente e resolvem de forma privada as demandas por assistência médica, no caso da vivência de enfermidades, e de assistência social, no caso de incapacitação. E, geralmente, os velhos ricos e saudáveis não são objeto de preocupação das políticas públicas, pois nem chegam a ser reconhecidos e nomeados por sua pertinência a um grupo etário, mas sim pelo seu poder e pelo lugar social distinto que ocupam na sociedade.

No caso do envelhecimento como problema social, o tema passa a tomar vulto por causa das céleres mudanças demográficas que, a partir da Segunda Grande Guerra, acontecem em todas as nações do mundo. A humanidade tem conseguido viver cada vez mais, graças ao controle de certas doenças, à queda nas taxas de fecundidade e de natalidade, à melhoria das condições de vida - que premiam desigualmente pobres e ricos, mas são abrangentes - e ao avanço das tecnologias de trabalho, saúde e lazer.

Em 1997, a vida média de uma pessoa, em termos mundiais, era de cerca de 66,7 anos. Contudo, as iniqüidades socioeconômicas e sanitárias se evidenciam quando se comparam as expectativas de vida de diversos países. Quem nasce no Japão, por exemplo, tem a chance de viver cerca de 80,0 anos, embora aquele que nasce em Serra Leoa tem uma expectativa de 37,2 anos - média próxima à da Idade Média (Pnud, 1999). 
O envelhecimento populacional suscita uma nova reflexão em torno da divisão do poder, assim como dos benefícios e problemas que esse fenômeno traz para as sociedades e o Estado. Sobretudo, torna-se fundamental a discussão de políticas públicas voltadas para uma categoria social que emerge com demandas muito específicas. $\mathrm{O}$ caso da América Latina é exemplar porque, a partir dos anos 80, mais da metade da população mundial de idosos vive em países de Terceiro Mundo (Veras, 1994; Videla, 1994), onde ainda não foram solucionados graves problemas de saúde e sobrevivência para outros grupos populacionais, historicamente majoritários, como é o caso de crianças, adolescentes e jovens.

A população brasileira também está envelhecendo. Sua expectativa de vida, que em 1970 era de 52,7 anos, passou para 66,1 anos em 1991 (Pnud, 1998) e 67,3, segundo dados preliminares do censo de 2000. Em 2025, o país deverá ter 32 milhões de pessoas com 60 anos e mais, o que corresponderá a 15\% da população (Brasil, 1996). Embora o prolongamento da vida em si seja um demonstrativo de melhores condições de sobrevivência, Sá (1997) pondera que o cuidado com o envelhecimento deve ser concebido com base em indicadores de qualidade da existência. Não basta viver muito, é importante viver bem.

No campo da saúde, a formulação política deve incluir a promoção de ações socioambientais e preventivas, além da ampliação da extensão e da intensidade dos equipamentos sociais de cuidados e atenção médica. Segundo Martine (1994), o tratamento das doenças que predominantemente afetam o idoso é mais demorado, e por isso mais caro, além de exigir equipamentos, medicamentos e profissionais especializados.

Com o envelhecimento de sua população em processo acelerado e a evidência de novas demandas, o país criou a Política Nacional do Idoso, concretizada na Lei $\mathrm{n}^{\mathrm{o}} 8.842$, de 4 de janeiro de 1994. Essa política foi votada no Congresso Nacional, após estudos e debates impulsionados pelas organizações governamentais e não governamentais interessadas no tema. Coube ao Ministério da Previdência e Assistência Social sua coordenação e promoção. A lei, que significa um avanço no sentido de dar publicidade a um assunto até então tratado de forma fragmentada ou restrito à esfera da família, visa, teoricamente, a evitar a exclusão da população idosa do processo de desenvolvimento do país e de seus eventuais benefícios (Brasil, 1996). O documento propõe, no que diz respeito à saúde, uma readequação da rede de serviços. Além disso, sugere a reformulação de currículos universitários, o desenvolvimento do turismo e do lazer, a assistência social integral ao idoso, dentre outras medidas (Brasil, 1996).

Apesar do avanço legal, a discussão que se tem travado na sociedade brasileira em relação ao envelhecimento de sua população tem primado por realçar o impacto e o ônus da população idosa na previdência e no setor saúde. O velho é visto como sinônimo de aumento dos gastos, tanto em um como em outro setor. É, inclusive, indevidamente responsabilizado pelos problemas provocados ora pela má administração pública, ora pelo uso inadequado dos escassos recursos dirigidos a ambos os setores. Não por acaso, esses foram os principais temas noticiados nas matérias jornalísticas aqui analisadas. 
As representações do idoso que se disseminam na sociedade - aqui trazidas da imprensa escrita - podem ser inicialmente distinguidas por meio das nomeações dos seus locais de internação. O termo 'casa de repouso' sugere ao mesmo tempo o momento em que os idosos se retiram das atividades obrigatórias à reprodução da família e a idéia de que a eles cabe se retirar da cena social, como é o caso do termo 'retiro', também freqüentemente usado para designar asilos. Por vezes, os donos de internatos recorrem a um eufemismo que induz a pensar na humanização do espaço, chamando-os de 'lar'. Todos os três termos convergem para as denominações mais comuns de 'abrigo' e 'asilo', que nomeiam um conjunto de equipamentos assistenciais, públicos, confessionais ou privados aos quais faltam normas, padrões e, sobretudo, respeito à subjetividade dos velhos que abrigam.

As exceções são muito poucas, elas mesmas confirmando a forte violência simbólica exercida sobre os abrigados na instituição. As situações de descaso, desmando e desrespeito fazem lembrar as descrições elaboradas por Goffman (1961) na análise do que denominou 'instituições totais'. Esse autor, cuja obra Asylum se tornou clássica como referência dos estudos de internatos, também evidenciou em seu trabalho o processo de naturalização dos freqüentes mecanismos de maus-tratos e os procedimentos uniformes que anulam as subjetividades, tais como foram encontradas nesta pesquisa. Esses dispositivos alienadores englobam tanto os internos quanto os profissionais que ali trabalham, como se fosse perenemente reproduzida uma cultura que envolve todas as pessoas que a criam e ao mesmo tempo são vítimas dela.

\section{Metodologia}

As perguntas que nortearam este estudo foram: como a sociedade encara e retrata seus idosos? Quais as perspectivas associadas à sua saúde e qualidade de vida? Como encarar o significado de potenciais mudanças para essa categoria social, no momento de seu acelerado crescimento no quadro demográfico nacional? Tudo isso, cabe ressaltar, visto por um instrumento de expressão da 'opinião pública', a imprensa escrita, dentro de um período determinado.

Buscou-se analisar os valores implícitos nas imagens e mensagens referidas ao 'idoso' e as respostas sociais e políticas a essa novidade demográfica. Como em qualquer estudo analítico, neste empregou-se uma abordagem qualitativa, evidenciando imagens e representações, atitudes e comportamentos que se revelam na dinâmica social das mensagens cotidianas do jornalismo brasileiro (Bardin, 1977; Minayo, 1994).

O material utilizado foi selecionado de diferentes diários do Rio de Janeiro e de São Paulo em dois períodos distintos: maio a setembro de 1996 e janeiro de 1997 a fevereiro de 1998.

Os periódicos da primeira etapa, em ordem pela quantidade de matérias, são: Jornal do Brasil (17); Folha de S.Paulo (6); O Globo (5); O Estado de S. Paulo (3); $O$ Dia (2); Jornal do Senado (1) e Jornal do Commercio (1), formando 35 enfoques. No 
segundo período foram consultados: Jornal do Brasil (31); O Globo (30); Folha de S.Paulo (9); O Dia (8) e O Estado de S. Paulo (1), num total de 79 abordagens.

$\mathrm{O}$ conjunto de textos analisados constituiu dois clippings (aqui entendidos como uma coletânea de matérias jornalísticas), cada um deles referindo-se a um dos períodos já citados. As matérias foram inicialmente selecionadas a partir do amplo recorte 'idosos'. Posteriormente, foram alocadas uma a uma, segundo o assunto principal abordado na notícia. Assim, tornou-se possível realizar classificações temáticas, organizadas conforme mostra a tabela a seguir.

Tabela 1 - Distribuição das matérias jornalísticas, segundo o tema, nos dois períodos analisados

\begin{tabular}{l|c|c|c}
\hline \multirow{2}{*}{ Tema } & \multicolumn{2}{|c|}{ Matérias jornalísticas } & \\
\cline { 2 - 3 } & maio a setembro de 1996 & janeiro de 1997 a fevereiro de 1998 & TotAL \\
\hline Saúde & 28 & 25 & 53 \\
Previdência & - & 28 & 28 \\
Demografia & 3 & 12 & 15 \\
Violência & - & 8 & 8 \\
Políticas públicas & 4 & 3 & 7 \\
Direitos & - & 3 & 3 \\
\hline ToтAL & 35 & 79 & 114 \\
\hline
\end{tabular}

No primeiro período (maio a setembro de 1996), a temática predominante foi a 'saúde'. Os demais temas noticiados nessa primeira etapa estiveram sempre interligados com 'políticas públicas' e 'demografia'.

No segundo período analisado (janeiro de 1997 a fevereiro de 1998), tiveram maior relevância e freqüência matérias relacionadas à 'previdência'. O tema 'saúde' ficou em segundo lugar, estando, contudo, bem próximo ao primeiro. A terceira temática em freqüência de divulgação foi a 'demografia', ressaltando-se, assim, a preocupação com o envelhecimento populacional da sociedade brasileira.

No conjunto, as grandes temáticas, em ordem quantitativa, foram: saúde (53 matérias); previdência (28 matérias) e demografia (15 matérias). Os jornais enfocaram ainda questões de 'violência', 'políticas públicas' e o tema dos 'direitos'.

Todas as matérias foram metodicamente resumidas em fichas para facilitar a leitura, cada uma incluindo: o título; a forma de destacar e iniciar a notícia; o fato narrado; os atores sociais e as partes envolvidas na questão; a maneira de nomear o idoso; a forma de abordá-lo, dando-lhe voz ou falando em seu nome por intermédio de terceiros; a apresentação de soluções para o problema debatido; a forma de encerrar a reportagem.

A partir da leitura das matérias, iniciou-se um processo de análise de seu conteúdo, utilizando-se técnicas já consagradas por Bardin (1977). Os dados foram ordenados, classificados, e depois procedeu-se à sua contextualização e compreensão hermenêutica (Minayo, 1994). 
Para este trabalho, a análise ficou restrita ao tópico 'saúde', dentro do qual foram abertos subtemas, cuja relevância foi inferida da estrutura das notícias. O primeiro em importância dada pelos jornais é a questão da 'institucionalização', que por sua vez foi aqui focalizada apenas na problemática dos abrigos para velhos. Esse assunto foi, em grande parte, potencializado pela crise desencadeada na Clínica Santa Genoveva, fato a que se referirá adiante com mais detalhes. O segundo subtema mais ressaltado nas matérias é o 'custo idoso', quase sempre tratado como um problema de difícil solução. O terceiro em ordem de importância é o da 'qualidade de vida do idoso como responsabilidade individual', o que configura uma posição ambígua entre a intenção de promoção de sua saúde e a tendência a culpabilizar os velhos pelos processos de adoecimento. Por fim, o quarto e último subtema apresenta a 'explicitação de uma crise do setor Saúde', a reboque da constatação do aumento demográfico da população idosa, como um problema a mais.

De todos, o subtema que aparece como o mais relevante é o da institucionalização, catalisando o discurso sobre os outros três pontos. Por sua vez, dentro de cada um deles, várias questões são levantadas e tratadas na análise do material.

\section{Saúde do ldoso, uma Preocupação da Sociedade?}

\section{A institucionalização ou as 'tragédias' nas 'Casas de horrores'}

Como já foi dito, dentro da temática 'saúde', a 'institucionalização' teve o maior número de matérias do universo analisado. Esse predomínio talvez se deva à ocorrência e repercussão, no período estudado, do incidente na Clínica Santa Genoveva (CSG), no Rio de Janeiro, onde mais de cem idosos morreram entre janeiro e maio de 1996, por doenças decorrentes do descuido, do descaso e da falta de higiene do local, sendo o fato desencadeador a alimentação contaminada servida aos internos. Guerra e colaboradores (2000) mostraram que, apesar da alta concentração de óbitos nos meses em que o escândalo pelo descaso veio à tona, uma mortalidade de idosos muito acima do esperado já vinha ocorrendo na Clínica Santa Genoveva desde 1993. Assim, se os dados do Sistema de Informações Hospitalares do SUS (SIH/SUS) tivessem sido utilizados numa vigilância adequada, tal tendência poderia ter sido detectada, evitando-se o cruel fenômeno expresso no excesso de mortes.

A análise da subtemática 'institucionalização' foi realizada com base nos seguintes eixos: problemas ocorridos na instituição; caracterização dos responsáveis; medidas adotadas em relação ao fato/evento e utilização do saber médico na justificativa das mortes dos idosos.

De início, a leitura das matérias já evidencia o caráter sensacionalista com que, geralmente, a imprensa aborda essa questão. Aqui, entende-se por sensacionalismo a forma de evidenciar com termos ou imagens exagerados qualquer acontecimento sociocultural e político que incremente a venda de jornais, sem preocupação de aprofundar, analisar, compreender e acompanhar realmente o sentido do problema, e 
que, ao sair do foco escandaloso e imediatista, é retirado também das pautas e das manchetes, mesmo quando se trata de um assunto socialmente relevante.

As matérias deram destaque ao número de mortos na Clínica Santa Genoveva, destacando este dado em seu título ou subtítulo. Tal recurso, típico do jornalismo sensacionalista, é usado para prender a atenção dos leitores na notícia, despertando a sua potencialidade emocional. O número foi estampado em 7 das 32 matérias relacionadas à temática.

Os problemas dos abrigos e residências para idosos puderam ser evidenciados primeiramente pela análise dos nomes atribuídos a esses locais após a identificação do descaso sofrido por eles e de sua morte. No primeiro período, fortes imagens foram invocadas para retratar a brutalidade da situação e o horror da mortandade em massa. A clínica, palco de um verdadeiro genocídio, foi designada pela imprensa como "casa dos horrores", "campo de concentração", "local de maus-tratos". O trecho a seguir, extraído da matéria 'Em dois meses, 84 idosos mortos', do jornal $O$ Globo, retrata bem essas idéias:

A abertura do portão da Clínica Santa Genoveva revelou ontem a existência de uma casa de horrores em Santa Teresa. (O Globo, 31/5/1996)

A mensagem do fatalismo também é encontrada neste eixo de análise. $\mathrm{O}$ fato ocorrido na Clínica Santa Genoveva é rotulado como tragédia. Tal representação pode ser ilustrada com o seguinte trecho:

Oito anos depois de um desabamento ter soterrado onze de suas enfermarias, a Clínica Santa Genoveva volta a ser palco de uma tragédia. ('Bactéria mata dez idosos em clínica', O Globo, 30/5/1996)

De fato, tragédia é, em sentido figurado, um acontecimento que desperta lástima ou horror. E as matérias invocam esse lamento e repúdio social ao descaso homicida a que foram submetidos os idosos. Mas é curioso ainda notar que a concepção original da tragédia grega está associada à própria idéia de fatalidade, destino e inexorabilidade. Tal como o dos heróis trágicos, o destino dos idosos estaria também à inteira mercê dos adultos detentores do poder, sem que sua subjetividade tivesse algum espaço de expressão.

Ressaltam-se, nas descrições jornalísticas desse primeiro período, as condições precárias das instituições e a falta de infra-estrutura, ao mesmo tempo que os jornais fazem um apelo à sensibilidade e à solidariedade social para angariar doações visando à manutenção e melhoria dos locais. Nesse momento, a narrativa já se amplia para uma espécie de diagnóstico indiferenciado da condição e da situação de todos os asilos e abrigos.

Entre os problemas de infra-estrutura, destacam-se, nas notícias, as péssimas condições de higiene; o oferecimento de comida estragada (foi encontrado um sapo em decomposição na geladeira da Clínica Santa Genoveva); a existência de banheiros imundos, de ralos destampados; a ausência de médicos nos plantões; além de irregularidades administrativas. Opiniões citadas em algumas matérias relacionam as irregularidades da clínica às suas dificuldades financeiras e à insuficiência da verba proveniente do governo. Mesmo que esses argumentos sejam, em parte, procedentes, tais 
peças jornalísticas deixam claro que, para muitos idosos, a longa internação está muito mais relacionada à garantia do lucro da empresa médica do que às necessidades do paciente.

No caso da Clínica Santa Genoveva, o relatório da Comissão Parlamentar de Inquérito da Assembléia Legislativa do Estado do Rio de Janeiro chegou à conclusão de que havia total falta de qualidade na assistência prestada. Alguns dos problemas detectados no relatório:

o esgotamento da lavanderia é feito na encosta, sem tratamento; panelas improvisadas e sistema elétrico danificado; roupas transportadas em trouxa; copa precisando de reparos; utilização de carne de segunda; hortifrutigranjeiros em quantidade insuficiente; refeições servidas aos pacientes em posicionamento e consistência inadequadas, todos recebem a mesma dieta, não importando a patologia; limpeza, iluminação e ventilação precárias na farmácia; a clínica não possuía laboratório próprio; as solicitações e resultados de exames não são registrados no prontuário médico do paciente; material esterilizado é guardado em prateleiras abertas; banheiros coletivos sem divisórias e sem apoio para deficientes; medicação irregular sem critério clínico preciso: utilização de benzodiazepínicos, que causam farmacodependência e utilização de fenobarbital [medicação para epilepsia] em pacientes sem história de epilepsia e com efeitos colaterais como sedação, depressão e distúrbio da memória. (Rio de Janeiro, 1997:2-7)

O documento enfatiza o fato de que todos os pacientes já estavam internados há muito tempo e que, praticamente, não houve altas de idosos nos últimos tempos. $\mathrm{O}$ relatório concluiu de forma contundente: "Os pacientes internados na Clínica Santa Genoveva estão expostos a riscos de vida", sentenciando:

a morte destes pacientes obriga o Poder Público, em todos os níveis de governo, a adotar medidas de punição contra as pessoas físicas e jurídicas que contribuíram ativamente ou por omissão para este desfecho trágico (....) e estão sujeitos às sanções de natureza penal, administrativa e civis, neste caso, medidas indenizatórias. (Rio de Janeiro, 1997:113)

Em relação ao segundo período, as idéias associadas a este eixo continuam apresentando referências às tragédias, ao fatalismo, às condições precárias e às irregularidades. Quando fatos semelhantes ao acontecido na Clínica Santa Genoveva se evidenciam em outras clínicas ou abrigos, são logo comparados ao ocorrido anteriormente. Porém, excepcionalmente, surgem matérias que apresentam fatos positivos, enfatizando qualidades de algumas instituições asilares, tratadas como locais agradáveis de onde o idoso não deseja sair:

O sol não esquenta a brisa fria no início da tarde, mas todos aproveitam o dia no pátio, nas varandas e nas salas de recreação da instituição. Alguns conversam, outros se reúnem para lançar mais uma edição do jornal Atividade. ('Um recanto de paz em meio à fumaça e ao barulho urbano', O Globo, 17/7/1997)

É importante destacar, neste ponto, que aí transparece uma certa ambivalência da sociedade em relação ao idoso. Por um lado, há no país uma tradição de manter os 
mais velhos em casa e envolvê-los em laços afetivos, numa convivência intergeracional. Por outro, as experiências mostram que essa convivência nem sempre é boa. Freqüentemente a pessoa do idoso é vista como um peso, pelos cuidados que requer em termos de alimentação, higiene, atenção médica, prevenção de acidentes, entre outros. Mas sua presença é igualmente apontada como fonte de dificuldades relacionais: são avós e netos que discutem por variados motivos, idoso e filho(a) que também divergem quanto aos hábitos e valores, sobretudo os referentes à criação da nova geração.

Na prática, esses conflitos e brigas tanto podem ser dirimidos como costumam levar à rejeição, ao isolamento do idoso, inviabilizando uma convivência saudável. Situações insustentáveis e, por vezes, inadequadamente resolvidas podem tender ora para a expressão de maus-tratos, ora para a expulsão dos parentes mais velhos de casa, rumo a abrigos ou asilos. Há casos em que o próprio idoso pede para ser internado, diz que "não quer dar trabalho", demonstrando o quanto se percebe como sinônimo de incômodo. Neste último caso, a família também vê esses locais como a solução para seus problemas.

Na verdade, algumas instituições conseguem se organizar de forma mais acolhedora, sendo consideradas, pelos que aí habitam, como seguras e mais apropriadas do que suas próprias famílias. Esse fato é enfatizado no seguinte depoimento de um idoso, extraído da matéria já citada: "Relutei um pouco para vir para cá, mas hoje sou capaz de relutar para não sair".

As matérias explicitam que grande parcela da população idosa está vivendo a realidade do abrigo, da casa de repouso, do asilo, do 'lar'. Esses espaços são, na sua maioria, identificados como depósitos de pessoas desprovidas do afeto da família e sem condições financeiras que lhes garantam o cuidado e o acompanhamento necessários. Os velhos vivem aí, garantidos por míseras aposentadorias. Um pequeno número dessas pessoas possui recursos financeiros que lhes permitiriam morar em residências que ofereçam um atendimento específico, personalizado e digno. Isso vai ao encontro da opinião publicada na matéria 'Saúde ignora idosos, afirmam médicos' (Folha de S.Paulo, 9/6/1996). Nela se diz que a minoria dos idosos fica em casa de repouso cinco estrelas, enquanto a maioria fica abandonada em 'lares' sem infra-estrutura.

O segundo eixo da subtemática 'institucionalização', a caracterização dos responsáveis pelas notícias dos jornais, revela que os donos das clínicas são apresentados pela imprensa como amigos do ministro da Saúde e como pessoas que têm fácil acesso a deputados, denotando a influência política de que se cercam em seus negócios. O jogo de interesses e as influências políticas, tão tradicionais no país, conforme discute Da Matta (1991), podem ser reconhecidos nos trechos a seguir:

'O ministro tem demonstrado que é muito condescendente e muito amigo dos donos dos hospitais', disse a vice-presidente da Comissão do Meio Ambiente da Assembléia Legislativa do Estado. ('Má impressão em dia de visita', Jornal do Brasil, 2/6/1996)

segundo a deputada S. A. (PFL), [o sócio da clínica] é muito influente no Ministério da Saúde... ('Estados reúnem campos de concentração', Jornal do Brasil, 3/6/1996) 
Mansur [sócio da CSG] também tem livre trânsito na bancada de donos de hospitais da Câmara dos Deputados... ('Estados reúnem campos de concentração', Jornal do Brasil, 3/6/1996)

A divulgação da amizade pessoal entre os donos da clínica onde morreram os idosos e o ministro da Saúde, bem como o fácil acesso daqueles aos deputados que constituem um lobby na defesa de seus negócios, permite uma dupla leitura: 1) a imprensa que denuncia o jogo de interesses, influências e benefícios estaria cumprindo sua 'função social' de informar à sociedade sobre a existência desse tipo de relações espúrias; 2) ao mesmo tempo que denuncia e informa tais condições de amizade e acesso, a imprensa também insinua e prevê que, na condição de poderosos e bem relacionados politicamente, os sócios da clínica sairão ilesos do episódio. Neste caso, a imprensa estaria, com a denúncia velada, indicando a histórica prática da impunidade para os crimes do colarinho branco, tão conhecidos e tão pouco punidos porque praticados pela 'gente bem' do país.

Outra idéia que a imprensa veicula é a da ganância empresarial dos donos das clínicas de idosos, que os leva a valorizar o lucro acima de tudo, não professando o mínimo respeito a seus clientes. O paradoxo dessa questão é que a saúde, um bem inegociável, é, neste caso, a 'mercadoria' vendida por tais empresários.

Até quando vamos conviver com esses empresários gananciosos que ameaçam a vida dos cidadãos brasileiros? ('As mortes anunciadas', O Dia, 1/7/1996, Opinião)

Landmann (1986), em seus estudos sobre a práxis médica, faz pensar, de forma radical, sobre os dilemas éticos para uma sociedade que transformou a saúde em objeto de compra e venda. Esse autor enfatiza que é "antiética a associação pecuniária do médico com o complexo médico industrial". Funcionar como empresário ou fazer parte de empresas conduz "a ignorar a responsabilidade pública da profissão médica na avaliação de drogas, equipamentos, de testes diagnósticos e procedimentos terapêuticos". Enfatiza também que, no caso empresarial, torna-se difícil delimitar "onde está o interesse pelo paciente e onde está o interesse pecuniário próprio” (Landmann, 1986:133-134).

O caso da Clínica Santa Genoveva se desdobrou na prisão do dono e de seus sócios, uma vez confirmada a suspeita de sua culpa pela morte em série dos idosos. Em relação a esse fato, a imprensa também se posicionou. E o que causa estarrecimento é que não faltaram matérias que tentaram sensibilizar o leitor para o drama pessoal que esses criminosos estariam vivendo ao serem presos. As matérias (que bem poderiam ser pagas) apresentaram os acusados como 'abalados', 'chocados', 'abatidos'. O subtítulo da matéria 'Crime não foi comprovado, diz advogado' não apenas lança dúvidas sobre uma situação que acabou sendo fatal como também critica as condições da cela de um dos sócios da CSG, ao colocar entre aspas a palavra especial: "Cela 'especial' abriga médico". É como se o mesmo jornal que noticiou, com tanta veemência, as tragédias vividas pelos idosos e suas famílias repentinamente as esquecesse ou duvidasse de sua veracidade, focalizando agora, com indignação, o fato de os médicosempresários estarem presos em locais desconfortáveis, sendo pessoas tão influentes. Eis fragmentos da matéria que trata do tema: 
O médico E. E., 50, um dos sócios da clínica Santa Genoveva, está preso em um pequeno quarto de cerca de $5 m^{2}$ no $23^{\circ}$ BPM, no Leblon [zona sul do Rio]. (Folha de S.Paulo, 28/6/1996)

O quarto tem apenas uma beliche. Para tomar banho, S. precisa sair do quarto. O banheiro, ao lado, não tem água quente. (Folha de S.Paulo, 28/6/1996)

M. J. M., que é hipertenso e sofre de problemas cardíacos, tomou medicamentos antes de se entregar. Segundo seu advogado, ele está vivendo sob forte tensão desde que foi decretada sua prisão. (O Estado de S. Paulo, 28/6/1996)

Da cobertura jornalística sobre o episódio depreende-se que não há uma sólida visão ou compreensão da gravidade da situação dos idosos, sobretudo dos mais pobres. Essa superficialidade na apresentação das questões reflete o próprio 'estado da arte' na sociedade, em que dominam a perplexidade, por vezes, a indignação e ainda muito pouco compromisso com soluções plausíveis e concretas. Assim, a ambigüidade do jornalismo que se expõe nas matérias sensacionalistas (Angrimani, 1995) costuma corresponder à acomodação do poder público, da sociedade e das famílias em particular. Ainda quando são avaliadoras, fazem juízo mas acabam por tomar posição efêmera. As matérias refletem o conceito do 'idoso como problema social' que tantas vezes aparece em qualquer estudo que hoje se produza sobre esse grupo etário. Por um lado, o genocídio de idosos causa horror (e produz boa chamada para as notícias); por outro, não suscita um debate mais profundo sobre como deveria ser tratado pela sociedade brasileira.

Em relação aos donos dos estabelecimentos, a impunidade, banalizada, se confirma no segundo período analisado, quando é mencionado, em apenas uma notícia, que os donos da Clínica Santa Genoveva estão livres e que continuam a comandar seis clínicas de atendimento ao idoso. $\mathrm{O}$ trecho retirado da matéria 'Morte de idosos amplia crise na saúde', publicado no Jornal do Brasil em 3 de fevereiro de 1998, mostra essa idéia:

Quase dois anos depois, os donos da clínica, os médicos M. J. M. e E. S., estão soltos e administrando cinco clínicas de que são sócios. No auge do caso, eles ficaram um mês na cadeia, mas o pedido de prisão foi relaxado.

Essa notícia revela o descaso com que os problemas dos idosos são tratados, ao mesmo tempo que retorna à conclusão anunciada pela própria imprensa, em matérias anteriores, como possível desfecho do caso: a absolvição dos poderosos responsáveis pela tragédia. Aqui, como se pode ver, prevaleceram a influência e o jogo de poder na Justiça, apesar da divulgação do escândalo, do relatório da Comissão Parlamentar de Inquérito e dos pronunciamentos de repúdio do Conselho Regional de Medicina.

É interessante, contudo, indagar por que apenas um jornal noticiou o veredicto que inocentou os donos da clínica. E a imprensa brasileira precisa, mais uma vez, ser aqui enfocada. Já se haviam passado dois anos do episódio na Clínica Santa Genoveva, e isso é tempo demasiado para o jornalismo que vive de (ou para) faits divers - fatos e notícias diárias, de gêneros diversos, que ocorrem no mundo, consideradas de importância circunstancial e que se constituem na principal fonte de 'alimentação' do noticiário sensacionalista (Angrimani, 1995). 
Outra questão que precisa ser considerada em relação a essa indagação é a tão criticada característica da mídia de dar destaque aos eventos delituosos e criminais, mas não cobrir, da mesma forma, o seu desmentido ou a sua resolução, seja ela reparadora ou incriminatória. No caso da Clínica Santa Genoveva, de uma forma bem genérica, a fraca vigilância da sociedade e da mídia permitiu que os responsáveis pela morte de mais de cem idosos saíssem impunes, inclusive inocentados pela sua entidade máxima de classe, que os absolveu das acusações.

O eixo 'medidas adotadas', que também se encontra inserido na subtemática 'institucionalização', mostra que os jornais noticiaram vários procedimentos empregados na solução dos problemas de infra-estrutura das instituições analisadas. Segundo a imprensa, foram constituídas medidas de controle (fiscalizações, vistorias, investigações); medidas punitivas (processo, prisão, intervenções, ameaça de fechamento); medidas preventivas preconizadas pela Política Nacional do Idoso (faixas nos meios de transportes, transferências de pacientes para outras instituições, criação local do Conselho de Defesa dos Direitos da Pessoa Idosa); medidas reformistas (criação de casaslares); medidas paliativas (faxina de emergência e obras de fachada nos prédios dos asilos). Quase todas as soluções apresentadas referem-se a procedimentos de controle. As de ordem preventiva, reformista e paliativa foram citadas em poucas matérias, em todo o período analisado.

A constatação advinda da presente análise vem reforçar uma tendência mais geral do setor saúde, e da própria sociedade, a adotar com mais facilidade medidas de controle e punição, em detrimento de propostas preventivas, de promoção e de bem-estar social. Aqui, vê-se claramente que a condição do idoso, suas dificuldades para sobreviver em ambientes tão hostis, com as fragilidades e debilidades próprias da idade ou por causa de enfermidades, não são pensadas em seu mérito próprio. Mesmo diante de uma tragédia como a da Clínica Santa Genoveva, a discussão e a mobilização limitam-se à agitação emocional, provocando um debate extremamente fugaz no meio jornalístico e entre os leitores. Nenhuma política mais duradoura é pensada com o vigor de uma sociedade que deseje realmente dar qualidade de vida à sua população idosa. Contudo, essa opção por medidas aparentemente mais fáceis, nos momentos de crise, cobra seu preço no futuro. No caso dos idosos, infelizmente, esse futuro foi bem próximo, como a própria imprensa noticiou ainda no período incluído nesta análise, conforme se verá adiante.

O último eixo observado na subtemática ‘institucionalização’ é o do saber médico como justificativa para as mortes ocorridas. Neste eixo, observa-se, num extremo que chega às raias do absurdo, a atribuição da culpa pelas mortes dos idosos da CSG a uma bactéria causadora da diarréia. A diarréia, na verdade, só agravou o quadro de doenças crônicas e debilidades já existentes entre os internos da clínica. A culpa dessa 'bactéria assassina' pode ser observada no título da notícia publicada no jornal $O$ Globo, no dia 30/5/1996: 'Bactéria mata dez idosos em clínica'. Essa mesma matéria, dando voz aos dirigentes da Clínica Santa Genoveva, insinua que a culpa pela dolorosa situação deve recair sobre os familiares dos internos:

A direção da clínica desconfia que os idosos tenham consumido algum alimento deteriorado oferecido pelos próprios parentes na festa realizada no Dia das 
Mães, dia 12 de maio. Apesar de a entrada de qualquer tipo de comida ser proibida, muitos receberam da família doces e biscoitos que conseguiram passar pela triagem. Para evitar novos incidentes, a direção da clínica promete tornar mais rigoroso o controle na portaria, impedindo que parentes tragam qualquer tipo de alimento.

No segundo período analisado, as notícias já se referiram a outras instituições nas mesmas condições precárias, quase sempre comparando-as ao caso negativamente exemplar da Clínica Santa Genoveva. Isso é evidenciado em:

O deputado disse que o lugar é pior que a Clínica Santa Genoveva, onde, entre abril e junho do ano passado, morreram 102 idosos. ('Idosos denunciam mau atendimento em abrigo', O Globo, 2/91997)

Em síntese, depreende-se, sob a ótica da imprensa, que o problema das instituições para idosos é generalizado e persistente. A matéria 'Intervenção não resolve problema de clínicas do Rio’ fala dessa questão:

Uma auditoria feita pelo Ministério da Saúde entre os dias 23 de abril e 16 de maio revelou que nenhuma das 15 clínicas que sofreram intervenção do Governo Federal em junho do ano passado tinha cumprido por completo as exigências de melhoria determinadas. (O Globo, 3/8/1997)

Ou seja, nenhuma medida de prevenção da reincidência do problema nem quaisquer medidas de controle foram, de fato, adotadas. Ainda assim, a mesma matéria apresenta a opinião do assessor da Secretaria Municipal de Saúde, para quem a situação das clínicas quanto à assistência ao paciente estaria melhor que há dois anos.

Nesse segundo período sob análise, as tragédias ocorridas em algumas outras clínicas e hospitais também foram bastante exploradas nas matérias, sendo relatados os casos do Hospital Eduardo Rabello (HER) e do Hospital Estadual Carlos Chagas (HECG). A primeira instituição, pertencente ao Centro de Geriatria e Gerontologia do governo estadual, é especializada no atendimento aos idosos e foi reconstruída com o intuito de melhor atendê-los. No entanto, seu funcionamento e os serviços continuaram a apresentar problemas. A matéria sobre o assunto leva a crer que o hospital foi reinaugurado apressadamente, apenas para efeitos políticos. Com a crise da Clínica Santa Genoveva, o governo estadual deu indicações de querer reparar, no âmbito público, a inadequação do setor privado em relação à assistência ao idoso. Porém, os mesmos descaso, descuido e insensibilidade humana vieram a acontecer em um de seus hospitais, evidenciando que é necessário algo mais que retórica e boa vontade.

Em menos de 24 horas, houve no Hospital Eduardo Rabelo cinco mortes ('Idosos sofrem com más instalações', Jornal do Brasil, 4/2/1998), cujas causas divulgadas foram o calor, a falta d'água e problemas de ventilação. A direção do hospital refere-se à ocorrência como uma "coincidência trágica", e a justifica pelo calor excessivo que apressou o estado terminal dos pacientes. A visita do secretário estadual de Saúde ao hospital foi noticiada, corroborando a mesma idéia da "coincidência trágica" e afirmando não haver comparação da instituição pública com a Clínica Santa Genoveva. 
As mesmas justificativas (calor, falta d' água e problemas de ventilação) foram alegadas para explicar 15 mortes no Hospital Estadual Carlos Chagas. Sua explicação é buscada no discurso pretensamente científico: "efeitos nefastos do calor no organismo" ('Vinte idosos morrem em dois hospitais', O Globo, 4/2/1998), tendo ocorrido a "síndrome de internação" ('Diretor do Carlos Chagas atribui ao calor mais uma morte de idoso no hospital', $O$ Globo, 5/2/1998). A matéria de $O$ Globo acrescenta uma pesquisa sobre a 'síndrome de internação', explicando ao leitor que ela é causada pela exposição a altas temperaturas, o que, em conseqüência, 'pode desligar' o mecanismo de controle térmico do corpo humano - que normalmente se resfria por meio do suor. A matéria também ressalta que os resultados da referida síndrome são a fraqueza, a desidratação, além de náuseas e distúrbios de consciência.

$\mathrm{O}$ argumento de que o calor tenha agravado doenças crônicas preexistentes não deveria, ou não poderia, ser usado para justificar as mortes. Se o calor era tão forte, caberia perguntar por que não foram tomadas medidas para amenizá-lo. Do mesmo modo, apelar para a noção de 'coincidência' mostra um certo cinismo nas falas das autoridades públicas, já que vinte mortes, em poucos dias, não podem ser encaradas apenas como acidente ou eventualidade.

Nas presentes tragédias, observa-se também que os idosos são mais uma vez culpabilizados por suas mortes, da mesma forma que as famílias foram acusadas pelos diretores da Clínica Santa Genoveva como responsáveis pela diarréia que os assolou. Ou seja, em ambos os casos, os discursos público e privado significam que os velhos internados nesses estabelecimentos, sendo pobres, subnutridos e abandonados pela família, estão com a vida permanentemente em risco. Assim, suas debilidades causaram-lhes a morte. Dessa maneira, o pretenso saber médico é utilizado como forma de burlar a responsabilidade dos gestores.

\section{0 'CUSTO IDOSO': RESUMO DE NOVAS CULPAS}

O segundo eixo encontrado nas matérias jornalísticas sobre o tema refere-se ao 'custo que o idoso representa à saúde pública'. A matéria 'Saúde ignora idosos, afirmam médicos' (Folha de S.Paulo, 9/5/1996), cujo título parece ser uma defesa dos velhos, na verdade apresenta, no seu conteúdo, uma 'denúncia' dos gastos excessivos do setor saúde com essa categoria de pessoas que consomem três vezes mais procedimentos e medicamentos do que o resto da sociedade. Na mesma notícia, evidencia-se que o Brasil não tem dinheiro para suprir todas as pessoas de serviços da saúde, insinuando, nas entrelinhas, que o idoso não é prioridade para o setor, num cenário de escassez de recursos.

Ora, tal idéia opõe-se frontalmente à atual Constituição brasileira, que estabelece ser a saúde direito de todos e dever do Estado. O tom acusatório da matéria coloca os velhos como responsáveis pelo problema do setor, por requererem mais cuidado médico e conseqüentes gastos. Essa culpabilização e a observada no eixo seguinte, no qual o idoso é responsabilizado pela sua própria saúde, dão uma noção do desamparo dessa faixa da população, cuja única saída seria rezar para não precisar de cuidados médicos. 
A situação dos planos privados de saúde também é analisada pela imprensa. Algumas matérias referem-se ao alto custo desses seguros para os próprios idosos. A matéria 'A dor no bolso dos idosos' (Jornal do Brasil, 24/8/1997) diz que "os custos de um seguro para um idoso é 16 vezes maior do que o de um jovem de 17 anos".

A regulamentação dos planos leva em conta que o atendimento aos maiores de 60 anos é mais caro. E isso é, decerto, um álibi usado para cobrar valores astronômicos pelas mensalidades. A matéria 'Atendimento ao idoso', publicada na Folha de S. Paulo em 28 de agosto de 1997, reflete o quanto a questão do 'custo' é enfatizada. Ela é enfocada sob dois ângulos diferentes e complementares: um aborda o ônus do atendimento; o outro se refere ao elevado custo, para o idoso, de garantir o seu próprio plano de saúde privado. Em linhas gerais, as matérias assinalam o dilema entre o custo público e a falta de condição dos mais velhos de arcar pessoalmente com os planos privados, sem que se apontem soluções plausíveis.

\section{QUALIDADE DE VIDA DO IDOSO: RESPONSABILIDADE INDIVIDUAL?}

O terceiro eixo que se verificou na cobertura jornalística da grande temática da saúde é 'o idoso como responsável e protagonista de sua qualidade de vida'. Dentre os assuntos abordados neste eixo estão o problema da depressão, como sendo comum nesta fase de vida; a vivência da sexualidade; a prática de esportes e o estilo de vida. As matérias tratam dos assuntos revelando que uma parcela da população idosa de médio ou alto poder aquisitivo está incrementando a indústria do turismo e do lazer, das academias de dança e ginástica e a indústria de cosméticos, que já perceberam aí uma promissora fatia do mercado consumidor. É a eles que se dirigem toda a publicidade e o marketing veiculados na mídia, enfocando o prolongamento do vigor e dos atributos de uma pretensa juventude.

As matérias que constituem esse eixo tendem a expressar a visão dominante de que os problemas de saúde são decorrentes de práticas e estilos de vida das pessoas. Tal concepção reduz ao nível individual todos os fatores determinantes e associados tanto das doenças como de práticas sociais saudáveis. Desconsideram a contribuição que fatores sociais e ambientais, de nível intermediário (como entidades, instituições e aparatos de incentivo, apoio, atenção e proteção da sociedade, que poderiam ser traduzidos em políticas públicas), bem como fatores de ordem mais geral (estruturais e culturais) têm na configuração da saúde e da doença.

Para Pereira (1992), se o enfoque dos determinantes da doença se restringir somente ao comportamento dos doentes, nada do âmbito político e econômico será feito para combater o aparecimento das enfermidades. A autora questiona ainda: se o cuidado com a saúde fosse mesmo apenas de responsabilidade individual, como ficariam as pessoas sem recursos socioeconômicos e em situações de vida que favorecem as condições de doença?

Na matéria 'Depressão é comum em idoso' (Jornal do Brasil, 5/1/1997), esse problema é veiculado como preocupação trazida pelo discurso médico. A matéria o coloca como um transtorno tratável que atinge $5 \%$ da população brasileira. Enfatiza que deve existir um cuidado especial na avaliação da depressão, pois, muitas vezes, o seu 
diagnóstico é confundido com o da demência, tendo em vista que ambas apresentam perdas cognitivas relacionadas à memória, ao raciocínio e à concentração.

Uma única matéria, com o título ‘Sexo do latino idoso' (O Globo, 20/11/1997), discorre sobre a sexualidade. Nela, o autor tenta esclarecer (sem aprofundar) que a sexualidade não é só genital, constituindo uma questão muito mais ampla e importante. Por isso, chama a atenção para a necessidade de que não haja preconceito da sociedade sobre o tema e para o fato de que, na velhice, é mais importante a qualidade do que a quantidade das relações sexuais. Na verdade, essa reportagem introduz uma novidade na forma tradicional como a sociedade vê e prevê o comportamento assexuado dos mais velhos.

Uma matéria, 'Longevidade dentro d'água' (Jornal do Brasil, 24/8/1997), focaliza as práticas esportivas hoje indicadas para idosos, mas trata exclusivamente da natação. Nela é dito que esse esporte fortalece o corpo e o ego, pois leva as pessoas a terem mais vontade de viver. Também evoca a idéia de valorização estética e do envelhecimento com qualidade de vida.

Nesse eixo, resumindo, o estilo de vida é colocado como o tema que deveria nortear as preocupações com o envelhecimento. Por isso, a responsabilidade por envelhecer bem seria, em última instância, do indivíduo. Na verdade, a preocupação com os estilos de vida é salutar, uma vez que hoje se tem conhecimento do seu impacto na prevenção ou no desencadeamento de muitas enfermidades. No entanto, ele é apenas um dos elementos num conjunto de condicionantes que também precisam ser considerados, tais como as condições de existência, o ambiente e a assistência médica.

\section{CRISE dA SAÚdE: de QUEM É a RESPONSABILIDADE?}

O quarto e último eixo que aparece na análise dos jornais é a 'crise da saúde', abordada por apenas uma matéria, 'Morte dos idosos amplia crise na saúde' (Jornal do Brasil, 3/2/1997). De acordo com a reportagem, essa crise revela uma dupla carência: falta de infra-estrutura dos serviços e falta de médicos, clínicos gerais e especialistas. A matéria também retorna ao caso da Clínica Santa Genoveva, mostrando que, graças à impunidade em relação à tragédia ocorrida, os mesmos problemas voltaram a acontecer. A reportagem lembrou os lamentáveis fatos ocorridos nos hospitais, o que levou o Conselho Regional de Enfermagem a realizar vistorias, mecanismos acionados quando irrompem problemas graves. Há que se lembrar que essas entidades, quando fazem sindicâncias, têm, em contrapartida, um ganho em status e visibilidade na mídia. Porém, suas atividades, necessárias e louváveis, por não aportarem uma proposta consistente, acabam por se constituir em eventos pontuais com pouquíssimas conseqüências positivas para o respeito aos direitos dos idosos a partir de então.

Os jornais noticiaram também o fato de que a crise dos hospitais levou à criação de um serviço, do tipo 'disque-denúncia', com a finalidade de receber queixas dos cidadãos contra irregularidades ocorridas nessas instituições. A gravidade da situação, no entanto, exigiria mais que isso. Se não há uma fiscalização sistemática e permanente, ocorrerão novos casos de negligência e maus-tratos, pois essa forma perversa de tratar os idosos já se tornou naturalizada nas instituições. 
O fato de a fala e a posição do idoso dos internatos, diante dos problemas que o afetam, somente serem garantidas por procuração mostra bem a posição de destituição de cidadania a que está submetido: outros falam por ele, considerado dependente ou incapaz de se expressar e defender seus pontos de vista e direitos. Segundo Lazaeta (1994), o modelo médico tradicional tem a velhice e a incapacidade como equivalentes. Esse autor mostra que a construção social da dependência do idoso se inicia com a aposentadoria vista, freqüentemente, como sinônimo de invalidez. Assim, cada vez mais, a sua identidade social é deteriorada, levando-o a considerar-se a si próprio como inútil e incapaz, internalizando o afastamento compulsório ou voluntário do convívio social e a discriminação que envolve o envelhecimento.

A visão da 'crise da saúde' tal como foi veiculada na imprensa, embora assinale o aumento do custo idoso e as carências de infra-estrutura, é abordada particularmente pelo olho que enxergou as tragédias, num tempo e num espaço específicos. Não abrange a contextualização dos problemas. É de se perguntar se o termo 'crise' dá conta da situação da política da saúde, porque este setor passa por uma conjuntura muito peculiar. Observa-se um promissor incremento da assistência pública e da universalização dos serviços, a partir do processo de municipalização de sua gestão. Além disso, a ênfase dada às mudanças no modelo de assistência, privilegiando os programas de 'saúde da família' e de 'agentes da saúde', tem potencializado uma relação mais pessoal e menos 'hospitalocêntrica' dos profissionais do setor com os usuários.

Hoje, o grande desafio do sistema reside, sobretudo, nos hospitais. Estes reúnem problemas de manutenção, de atualização de equipamentos, de escassez de pessoal e, não menos importante, reproduzem um modelo de atenção burocratizado e impessoal, cuja figura principal não é o doente, e sim a doença, não é o sujeito enfermo, e sim o médico. Ora, tais questões não podem ser atribuídas aos idosos. Elas são estruturais e estruturantes da realidade. A situação do envelhecimento da população - e, como consequiência, o aumento das doenças crônico-degenerativas, que geralmente acompanham esse processo - e o fato de o aumento da demanda por cuidados ser proveniente dos grupos mais pobres colocam luz sobre as deficiências do setor. Chamar 'crise' a esse fenômeno é desconhecer os avanços e, ao mesmo tempo, tratar problemas crônicos como passageiros. Na verdade, a situação de falência dos hospitais, sobretudo dos públicos, já dura mais de 20 anos.

Além de todas as questões aqui tratadas, é preciso ter clareza de que a assistência aos idosos constitui um verdadeiro nó górdio. O Brasil, embora tenha definido uma política, cujo gestor principal deveria ser o Ministério da Previdência, nem ao menos tentou implantar um programa de assistência consistente e eficiente. Propostas a serem adaptadas não faltam, principalmente por parte de países que hoje poderiam ser considerados modelos, como é o caso da Espanha. 


\section{CONCLUSÕES}

Concluindo este estudo, podem ser evidenciados vários pontos, mas aqui serão enfatizados apenas alguns deles. De um modo geral, pode-se dizer que, nas matérias jornalísticas pesquisadas, poucas vezes os idosos tiveram chance de se expressar e ter sua opinião publicada. Das 32 matérias analisadas sobre a temática 'institucionalização', a grande maioria não deu voz nem ao idoso nem a algum representante seu. Somente em quatro reportagens isso foi feito, mas de forma indireta, por meio do depoimento de seus familiares. Em apenas sete o idoso pôde se expressar diretamente.

Em seguida, constata-se que cresce, de forma ainda tímida, a preocupação com a parcela idosa da população e com os problemas por ela vivenciados. Pensando na imprensa como caixa de ressonância das questões apresentadas, seja pela sociedade, seja pelo Estado, isso está expresso no incremento do número de matérias e da diversidade de temas enfocados pelos jornais consultados neste estudo.

Essa maior atenção à população idosa na realidade brasileira se deve, em parte, à conscientização sobre a presença desses idosos em número cada vez maior e ao surgimento - a partir desta mesma conscientização - de um movimento social de luta pela busca de soluções públicas para os problemas que vivenciam. Porém, o grande protagonista desse movimento são os próprios idosos, que vêm se reorganizando em associações reivindicativas de aposentados, clubes, grupos culturais, esportivos e de lazer, em grande medida ainda incipientes, visando a garantir o direito à vida longa com qualidade. Esse bloco dos idosos ativos, ainda muito pouco retratado pela mídia, constitui a cellula mater de um 'protagonismo' insubstituível e que tende a crescer. A visão mais positiva do idoso, como portador de experiência e cidadão participativo nas decisões e nos rumos de seu destino, na verdade, se dá no âmbito de uma mudança política e que revolve as entranhas dos interesses estabelecidos e dos núcleos de poder dos adultos.

Os velhos que a mídia tem retratado são principalmente aqueles que fazem parte dos segmentos mais pobres ou são, pelos mais diferentes motivos, abandonados por suas famílias, ficando dependentes da assistência pública, da caridade dos grupos religiosos ou do oportunismo de quem aí descobriu um filão inesgotável de exploração da miséria, do desamparo e até da invalidez. É claro que, como sujeitos, os idosos também têm algum poder de vocalização, nem que seja mínimo. Pois o próprio espetáculo triste, duro e cruel de seu sofrimento, recorrentemente apresentado nos jornais e na televisão, expõe à própria sociedade sua incapacidade de lidar com esse grupo social, a não ser como um 'problema insolúvel'. Pensando de forma otimista, isso pode ser um princípio de diagnóstico para propostas menos cínicas e mais efetivas. É claro que se existem clínicas que em si são verdadeiras tragédias é porque familiares, governo e sociedade reagem apenas emocional e fugazmente aos episódios mostrados de tempos em tempos. Depois recolhem-se, rapidamente, nos cuidados de seus próprios interesses.

Outro ponto que merece destaque é a forma pontual e superficial com que a opinião pública trata a questão. Essa abordagem superficial e freqüentemente sensacionalista favorece o corporativismo dos profissionais que falham nos cuidados, dos donos das entidades que os exploram e do poder público, que não assume colocar em 
prática a política nacional. No auge das crises e das denúncias, medidas são sugeridas e depois não se efetivam, propiciando a repetição das tragédias e o total desrespeito aos velhos que necessitam de assistência. As políticas públicas preventivas pouco ou nada são debatidas na mídia, até porque elas significariam uma outra ótica em relação ao grupo social em questão, a ótica sob a qual os idosos não são 'um problema', mas uma riqueza da humanidade e para a humanização da sociedade brasileira.

É também digno de nota o fato de que as instituições (asilos, clínicas, abrigos) devem ser acompanhadas sistematicamente pelas autoridades da saúde e pela sociedade. É inadmissível que ocorram mortes em lotes de centenas de pessoas e a impunidade continue reinante. Mais triste ainda é ver que nem esses genocídios que ainda comovem a opinião pública suscitam uma atuação real na aplicação da atenção ao idoso. Em vez disso, esses fatos funestos são retratados na tinta sensacionalista de uma tragédia, rapidamente banalizada meses depois e, pior, revivida logo em seguida.

Igualmente revelador da ambígua posição que a sociedade toma diante de seus membros mais velhos é a ação sutil de negar a voz aos sujeitos desse debate. Seu 'protagonismo' é seqüestrado por 'representantes', ou simplesmente ignorado.

Finalmente, cabe também repensar o papel que a imprensa tem desempenhado diante da situação do idoso. Apenas revelar os estigmas e preconceitos que a sociedade cria em relação a eles é pouco para uma ética da comunicação social. Além de discutir esses dilemas, caberia a ela abrir canais de debate e de aprofundamento de uma mudança cultural no sentido da implantação efetiva de uma política de promoção da saúde e de assistência social aos idosos. Responsáveis, em grande parcela, pela formação de uma 'opinião pública' e de um imaginário social, a imprensa poderia afirmar a necessária postura de positividade em relação ao idoso para que este fosse reconhecido como produtivo, capaz, experiente, mas também como portador de necessidades específicas e, sobretudo, digno de respeito como pessoa e cidadão.

\section{ReferênCias Bibliográficas}

ANGRIMANI, D. Espreme que Sai Sangue: um estudo do sensacionalismo na imprensa. São Paulo: Summus, 1995.

RIO DE JANEIRO. Assembléia Legislativa. Relatório e Conclusão dos Trabalhos da Comissão Parlamentar de Inquérito sobre a Morte de Idosos na Clínica Santa Genoveva. Rio de Janeiro, 1997.

BARDIN, L. Análise de Conteúdo. São Paulo: Edição 70, 1977.

BRASIL. Ministério da Saúde. Política Nacional do Idoso: perspectiva governamental. Brasília: SEMINÁRIO INTERNACIONAL ENVELHECIMENTO POPULACIONAL: UMA AGENDA PARA O FINAL DE SÉCULO, 1996.

DA MATTA, R. A Casa e a Rua: espaço, cidadania, mulher e morte no Brasil. 4.ed. Rio de Janeiro: Guanabara Koogan, 1991. 
GOFFMAN, E. Asylums: essays on the social situation on mental patients and others inmates. Nova Iorque: The Anchor Books, 1961.

GUERRA, H. L. et al. A morte de idosos na Clínica Santa Genoveva, Rio de Janeiro: um excesso de mortalidade que o sistema público de saúde poderia ter evitado. Cadernos de Saúde Pública, 16(2):545-551, 2000.

LANDMANN, J. Evitando a Saúde e Promovendo a Doença. Rio de Janeiro: Guanabara Dois, 1986.

LAZAETA, C. B. Aspectos sociales del envejecimiento. In: ORGANIZACIÓN PANAMERICANA DE LA SALUD. La Atención de los Ancianos: un desafío para los años noventa. Washington: Paho, 1994.

MARTINE, G. (Coord.) Mudanças Recentes no Padrão Demográfico Brasileiro e Implicações para a Agenda Social. Texto para discussão nº 345. Brasília: Ipea, 1994.

MINAYO, M. C. S. O Desafio do Conhecimento. São Paulo: Hucitec, 1994.

PEIXOTO, C. Entre o estigma e a compaixão e os termos classificatórios: velho, velhote, idoso, terceira idade. In: LINS DE BARROS, M. M. (Org.) Velhice ou Terceira Idade? Rio de Janeiro: Fundação Getúlio Vargas, 2000.

PEREIRA, R. C. J. Promoção de saúde e prevenção de doenças: responsabilidade individual ou responsabilidade social. Revista da Escola de Enfermagem USP, 26(3):345-50, 1992.

PROGRAMA DAS NAÇÕES UNIDAS PARA O DESENVOLVIMENTO (PNUD). Desenvolvimento Humano e Condições de Vida: indicadores brasileiros. Projeto Desenvolvimento Humano no Brasil. Brasília: Pnud, 1998.

PROGRAMA DAS NAÇÕES UNIDAS PARA O DESENVOLVIMENTO (PNUD). Relatório de Desenvolvimento Humano. Lisboa: Trinmora, 1999.

SÁ, V. M. T. P. L. O 'Novo Velho'e as Políticas Sociais: e o setor de saúde, como se manifesta?, 1997. Dissertação de Mestrado, Rio de Janeiro: Escola Nacional de Saúde Pública, Fundação Oswaldo Cruz, 1997.

VERAS, R. País Jovem de Cabelos Brancos: a saúde do idoso no Brasil. Rio de Janeiro: RelumeDumará, Uerj, 1994.

VIDELA, J. F. Los ancianos y las políticas de servicios en América Latina y el Caribe. In: ORGANIZACIÓN PANAMERICANA DE LA SALUD. La Atención de los Ancianos: un desafío para los años noventa. Washington: Paho, 1994. 
Formato: 16 × $23 \mathrm{~cm}$

Tipologia: Times New Roman

Bauer Bodoni BT

Papel: Pólen Bold $70 \mathrm{~g} / \mathrm{m}^{2}$ (miolo)

Cartão Supremo $250 \mathrm{~g} / \mathrm{m}^{2}$ (capa)

Fotolitos: Laser vegetal (miolo)

Engenho \& Arte Editoração Gráfica Ltda. (capa)

Reimpressão e acabamento: Imprinta Express Gráfica e Editora Ltda.

Rio de Janeiro, junho de 2011.

Não encontrando nossos títulos em livrarias,

contactar a EDITORA FIOCRUZ:

Av. Brasil, 4036 - 1 andar - sala 112 - Manguinhos

21040-361 - Rio de Janeiro - RJ

Tel.: (21) 3882-9039 e 3882-9007

Telefax: (21) 3882-9006

www.fiocruz.br/editora

e-mail: editora@fiocruz.br 